UNIVERSIDADE REGIONAL DE BLUMENAU - FURB CENTRO DE CIÊNCIAS SOCIAIS APLICADAS

DOUTORADO EM CIÊNCIAS CONTÁBEIS E ADMINISTRAÇÃO

INFLUÊNCIA DA POLÍTICA DE REMUNERAÇÃO DOS EXECUTIVOS NO NÍVEL DE GERENCIAMENTO DE RESULTADOS EM EMPRESAS INDUSTRIAIS BRASILEIRAS, ESTADUNIDENSES E INGLESAS

DÉBORA GOMES MACHADO 
DÉBORA GOMES MACHADO

INFLUÊNCIA DA POLÍTICA DE REMUNERAÇÃO DOS

EXECUTIVOS NO NÍVEL DE GERENCIAMENTO DE RESULTADOS

EM EMPRESAS INDUSTRIAIS BRASILEIRAS, ESTADUNIDENSES E INGLESAS

Tese apresentada ao Programa de Pós-graduação em Ciências Contábeis da Universidade Regional de Blumenau como requisito parcial à obtenção do título de Doutora em Ciências Contábeis e Administração, área de concentração Controladoria.

Orientadora: Prof. ${ }^{a}$ Ilse Maria Beuren, Dra. 


\title{
INFLUÊNCIA DA POLÍTICA DE REMUNERAÇÃO DOS \\ EXECUTIVOS NO NÍVEL DE GERENCIAMENTO DE RESULTADOS \\ EM EMPRESAS INDUSTRIAIS BRASILEIRAS, ESTADUNIDENSES E INGLESAS
}

\author{
DÉBORA GOMES MACHADO
}

Esta tese foi julgada adequada para obtenção do título de Doutora em Ciências Contábeis e Administração, área de concentração Controladoria, e aprovada em sua forma final pelo Programa de Pós-Graduação em Ciências Contábeis da Universidade Regional de Blumenau.

$$
\begin{gathered}
\text { Prof. a Ilse Maria Beuren, Dra. } \\
\text { Coordenadora do PPGCC }
\end{gathered}
$$

Banca examinadora:

Presidente (Orientadora): Prof ${ }^{\mathrm{a}}$. Ilse Maria Beuren, Dra.

Programa de Pós-Graduação em Ciências Contábeis (PPGCC)

Universidade Regional de Blumenau (FURB)

Membro Titular: Prof. Jorge Eduardo Scarpin, Dr.

Programa de Pós-Graduação em Ciências Contábeis (PPGCC)

Universidade Regional de Blumenau (FURB)

Membro Titular: Prof. Nelson Hein, Dr.

Programa de Pós-Graduação em Ciências Contábeis (PPGCC)

Universidade Regional de Blumenau (FURB)

Membro Titular: Prof. César Augusto Tibúrcio Silva, Dr.

Programa Multiinstitucional e Inter-Regional de Pós-Graduação em Ciencias Contábeis (UnB/UFPB/UFRN)

Universidade de Brasília (UNB)

Membro Efetivo: Prof. Moacir Sancovschi, Dr.

Programa de Pós-Graduação em Ciências Contábeis da Faculdade de Administração e Ciências Contábeis

Universidade Federal do Rio de Janeiro (UFRJ)

Blumenau, 23 de abril de 2012. 


\section{Dedicatória}

Dedico este trabalho, com muito amor e carinho, ao meu esposo Róginei e às nossas filhas Rafaela e Daniela. 


\section{AGRADECIMENTOS}

Agradeço a Deus, por me permitir desfrutar de saúde e paz, pela benção de estar cercada por pessoas de bem, por ter me dado à oportunidade de aprendizado e progresso a cada dia. Senhor muito obrigada.

Agradeço aos meus pais Vera e Luís, pela minha vida que conceberam, pelo exemplo de simplicidade e humildade que dão diariamente, pelo apoio, amor e atenção incondicional dispensados a mim, ao meu esposo, e às netas. Amo muito vocês.

Agradeço ao meu esposo Róginei, pelo apoio e incentivo dispensado sempre, pela compreensão das minhas inquietações e dos momentos de ausência, por compartilhar comigo momentos certos e incertos da vida, por acumularmos as diversas experiências da vida juntos. Serei eternamente grata a você. Amo-te muito minha cara-metade.

Agradeço às minhas filhas Rafaela e Daniela, pela motivação nos momentos difíceis, pelo sorriso, pela alegria de viver, por compreender os longos períodos de ausência. Sem vocês a busca pelo progresso não teria sentido, vocês são parte de mim e eu as amo com todas as forças do meu coração.

Agradeço à minha orientadora, professora Ilse, pela orientação deste trabalho, pelos sábios conhecimentos que me foram transmitidos ao longo das disciplinas, dos seminários e do período de orientação, pelo exemplo de vida e de dedicação, pelo convívio sereno e de pulso firme sempre. Obrigada professora por tudo, jamais esquecerei o seu exemplo.

Agradeço ao corpo docente, em especial aos professores Scarpin, Nelson, Lavarda e Bezerra, pelos preciosos conhecimentos e conselhos transmitidos durante todo o curso, no desenvolvimento dos seminários, das aulas, dos artigos das disciplinas e pela encantadora convivência. Muito obrigada professores.

Agradeço aos colegas de turma, doutorandos (Tarcísio, Rodrigo, Cosmo, Giancarlo, Edson, Paulo, Klann, Paton e Lígia) e mestrandos (Araceli, Juliana, Marlene, Geovanne, Lara e Odir), que compartilharam comigo as disciplinas, os seminários e as pesquisas, pela colaboração, atenção, alegria, preocupação e motivação compartilhadas. Queridos colegas, muito obrigada pela convivência.

A todos os demais colegas das turmas seguintes: a) de mestrado, especialmente ao Moacir e ao Paulo Sérgio; b) de doutorado, especialmente à Francivânia e Delci. Obrigada queridos, por tudo que fizeram por mim, pelos pensamentos bons e pelo apoio sempre que precisei.

Agradeço às colegas de moradia (Juliana, Marlene, Araceli, Clésia, Dalci, Francivânia, Delci, Márcia, Andreia, Ieda, Nádia, Andressa, Elis e Eliane), pela convivência, alegria, responsabilidades compartilhadas e pelo aprendizado que me proporcionaram. As dificuldades ensinam muito mais do que as facilidades. Assim, creio que a convivência nos proporcionou uma 
mistura de perfis, culturas e sonhos. Colegas obrigada por tudo, levarei vocês comigo sempre, desejo progresso e sucesso a todas.

Agradeço em especial ao doutorando Tarcísio e à mestranda Araceli, pela amizade, apoio, incentivo, e intensos dias compartilhados. Amigos, vocês moram no meu coração, e por mais que eu busque palavras, seria impossível descrever tudo que vivemos e construímos juntos. Agradeço a Deus por vocês terem feito parte da minha trajetória.

Agradeço à secretária Rosane, pela sua eficiência, boa vontade e disposição em resolver tudo que precisamos no Programa. Agradeço à Silvane e ao Lourenço, vigias da FURB, pelo sorriso, lágrimas, carinho e atenção dispensados e compartilhados ao longo do curso, bem como nos feriados, fins de semanas e sempre. Adoro vocês queridos amigos.

Agradeço a todos os amigos e a todos os meus alunos, em especial ao Jonathan e à Claudinha, que me apoiaram nos momentos mais difíceis, bem como a todos que de alguma forma contribuíram para que eu pudesse concluir essa etapa da minha vida acadêmica. Queridos amigos e alunos, obrigada e que Deus os abençoe sempre. 
"Se não puder se destacar pelo talento, vença pelo esforço". 


\section{RESUMO}

MACHADO, Débora Gomes. Influência da política de remuneração dos executivos no nível de gerenciamento de resultados em empresas industriais brasileiras, estadunidenses e inglesas. 2012. 273f. Tese (Doutorado em Ciências Contábeis e Administração) - Programa de PósGraduação em Ciências Contábeis da Universidade Regional de Blumenau, Blumenau, 2012.

Um dos incentivos para a prática de gerenciamento de resultados nas empresas advém dos contratos entre principal e agente. A remuneração do executivo se constitui em mecanismo de vinculação entre os mesmos, que se origina da Teoria da Agência, vislumbrando a redução de conflitos e de assimetria informacional. A disseminação expressiva de pesquisas sobre a remuneração dos executivos nos Estados Unidos foi identificada na revisão de literatura, com diferentes enfoques, mas escassa na Inglaterra e no Brasil. Assim, o estudo objetiva identificar a influência da política de remuneração dos executivos no nível de gerenciamento de resultados sob a ótica das escolhas contábeis por meio de atividades operacionais e accruals discricionárias em empresas industriais brasileiras, estadunidenses e inglesas. Uma pesquisa descritiva com abordagem quantitativa foi realizada com a aplicação da proposição de Murphy (1999) para segregar a remuneração dos executivos nas perspectivas de nível e estrutura; e do modelo de Anderson, Banker e Janakiraman (2003), Gunny (2005), Roychowdhury (2005) e de Dechow, Sloan e Sweeney (1995) para estimar os níveis de gerenciamento de resultados. Os dados da pesquisa foram coletados em documentos contábeis dos exercícios de 2007 a 2010 para a remuneração dos executivos e de 2005 a 2010 para o gerenciamento de resultados. A amostra contou com 400 empresas industriais, sendo 30 brasileiras, 47 inglesas e 323 estadunidenses. Os resultados mostram que a remuneração dos executivos estadunidenses é maior do que a dos executivos brasileiros e ingleses, e que grande parte de sua remuneração é baseada em ações. O maior nível de gerenciamento de resultados por atividades operacionais, despesas com vendas, gerais e administrativas ocorreu nas empresas industriais inglesas, porém por accruals discricionárias foi maior nas empresas brasileiras. Conclui-se que há influência da política de remuneração no nível de gerenciamento de resultados, por meio de atividades operacionais e accruals discricionárias, e que a idade e expertise do executivo influenciam esta relação, assim como o segmento, desempenho e tamanho da empresa.

Palavras-chave: Remuneração de executivos. Gerenciamento de resultados. Manipulação de atividades operacionais. Manipulação de accruals discricionárias. Empresas industriais. 


\begin{abstract}
MACHADO, Débora Gomes. Relationship between executive compensation plans and the earnings management in Brazilian, American and English industrial companies. 2012. 273f. Thesis (Accountings and Management Doctorate) - Postgraduate Program in Accounting at the Universidad Regional de Blumenau, Blumenau, 2012.
\end{abstract}

One of the incentives for the practice of earnings management in companies comes from contracts between the principal and the agent. The executive compensation constitutes a linking mechanism between them, which stems from the Theory of Agency, seeking the reduction of conflicts and information asymmetry. The significant dissemination of research on executive compensation in the United States was identified in the literature review, with different approaches, but scarce in England and Brazil. Thus, this study aims to identify the influence of policy on executive compensation at the level of earnings management from the perspective of accounting choices by real activities and discretionary accruals in Brazilian, American and English industrial companies. A descriptive study with a quantitative approach was carried out with the application of Murphy's proposition (1999) to segregate the compensation of executives in the prospects for level and structure; the models of Anderson, Banker and Janakiraman (2003), Gunny (2005), Roychowdhury (2005) and Dechow, Sloan and Sweeney (1995) to estimate the levels of earnings management. The survey data was collected in the accounting documents of the years 2007-2010 for the remuneration of executives and from 2005 to 2010 for earnings management. The sample consisted of 400 companies, 30 of which are Brazilian, 47 British and 323 American. The results show that the American executive compensation is higher than that of Brazilian and English executives, being much of their compensation based on shares. The highest levels of earnings management by operational activities, selling, general and administrative expenses occurred in English companies. However, when it came to discretionary accruals, those levels were higher in Brazilian companies. We conclude that there is an influence of the remuneration policy on the level of earnings management through discretionary accruals and real activities. Furthermore, the age and expertise of the executive also play a part in this relationship, as well as the segment, performance and company size.

Keywords: Executive compensation. Earnings management. Real activities manipulation. Discretionary accruals manipulation. Industries companies. 


\section{RESUMEN}

MACHADO, Débora Gomes. Influencia de la política de remuneración de los ejecutivos a nivel de gerenciamiento de resultados en empresas industriales brasileñas, estadunidenses e inglesas. 2012. 273f. Tesis (Doctorado en Ciências Contábeis e Administração) - Programa de Posgrado en Ciências Contábeis de la Universidade Regional de Blumenau, Blumenau, 2012.

Uno de los incentivos para la práctica de gerenciamiento de resultados en las empresas proviene de los contratos entre principal y agente. La remuneración del ejecutivo se constituye en mecanismo de vinculación entre los mismos, que se origina de la Teoría da Agência, vislumbrando la reducción de los conflictos y de la asimetría de información. Diseminación expresiva de investigaciones sobre la remuneración de los ejecutivos en Estados Unidos fue identificada en la revisión de literatura, con diferentes enfoques, pero escasa en Inglaterra y en Brasil. Así, el estudio tiene como objetivo identificar la influencia de la política de remuneración de los ejecutivos a nivel de gerenciamiento de resultados, bajo la perspectiva de las elecciones contables mediante actividades operacionales y accruals discrecionales en empresas industriales brasileñas, estadunidenses e inglesas. Investigación descriptiva con enfoque cuantitativo fue realizada con aplicación de la proposición de Murphy (1999) para segregar la remuneración de los ejecutivos en las perspectivas de nivel y estructura; y del modelo de Anderson, Banker y Janakiraman (2003), Gunny (2005), Roychowdhury (2005) y de Dechow, Sloan y Sweeney (1995) para estimar los niveles de gerenciamiento de resultados. Los datos de la investigación fueron recogidos en documentos contables de 2007 a 2010 para la remuneración de los ejecutivos y de 2005 a 2010 para el gerenciamiento de resultados. La muestra contenía 400 empresas industriales, siendo 30 brasileñas, 47 inglesas y 323 estadunidenses. Los resultados muestran que la remuneración de los ejecutivos estadunidenses es mayor que la de brasileños e ingleses y que gran parte de su remuneración es basada en acciones. El mayor nivel de gerenciamiento de resultados por actividades operacionales, gastos con ventas, generales y administrativos ocurrió en empresas industriales inglesas, pero por accruals discrecionales fue mayor en las empresas brasileñas. Se concluye que hay influencia de la política de remuneración en el nivel de gerenciamiento de resultados, mediante actividades operacionales y accruals discrecionales, y que la edad y competencia del ejecutivo influencian esta relación, así como el segmento, desempeño y tamaño de la empresa.

Palabras-clave: Remuneración de ejecutivos. Gerenciamiento de los resultados. Manipulación de actividades operacionales. Manipulación de accruals discrecionales. Empresas industriales. 


\section{LISTA DE FIGURAS}

Figura 1 - Paradigmas para análise da teoria social ...........................................31

Figura 2 - Síntese da trajetória epistemológica que fundamenta esta tese .........34

Figura 3 - Síntese da trajetória epistemológica da teoria dos contratos .............40

Figura 4 - Síntese da trajetória epistemológica da teoria da agência...................51

Figura 5 - Síntese da trajetória epistemológica da remuneração de executivos 54

Figura 6 - Síntese da trajetória epistemológica do gerenc. de resultados ...........57

Figura 7 - Modelo básico de agência ...............................................................58

Figura 8 - Diagrama ilustrativo das accruals .................................................... 74

Figura 9 - Relações entre as diversas formas de gerenciamento de resultados .76

Figura 10 - Espaço metodológico quadripolar .................................................109

Figura 11 - Grupo I de hipóteses.................................................................138

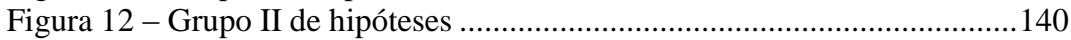

Figura 13 - Grupo III de hipóteses ...........................................................142

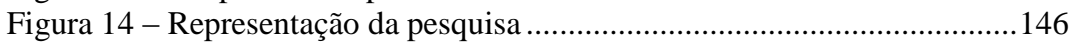

Figura 15 - Sequência lógica da análise dos dados .........................................146

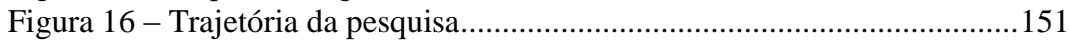

Figura 17 - Hipóteses confirmadas no Grupo I .............................................221

Figura 18 - Hipóteses confirmadas no Grupo II............................................224

Figura 19 - Hipóteses confirmadas no Grupo III ...........................................2238 


\section{LISTA DE QUADROS}

Quadro 1 - Visão geral da teoria da agência.................................................. 48

Quadro 2 - Periódicos nacionais - remuneração de executivos .......................... 67

Quadro 3 - Pesquisas nacionais - remuneração de executivos .......................... 68

Quadro 4 - Periódicos internacionais - remuneração de executivos.................... 70

Quadro 5 - Pesquisas internacionais - remuneração de executivos ................... 71

Quadro 6 - Periódicos nacionais-ger. resultados e planos de remuneração ...... 96

Quadro 7 - Pesquisas nacionais - ger. resultados e planos de remuneração ..... 97

Quadro 8 - Periódicos internacionais - ger. resultados e planos de remun....... 98

Quadro 9 - Pesquisas internacionais - ger. resultados e planos de remun. ....... 99

Quadro 10 - Amostra de empresas brasileiras ................................................ 119

Quadro 11 - Amostra de empresas estadunidenses ........................................... 122

Quadro 12 - Amostra de empresas inglesas ................................................... 123

Quadro 13 - Constructos da pesquisa .......................................................... 126

Quadro 14 - Mensuração da expertise .......................................................... 134

Quadro 15 - Fonte dos dados da pesquisa ..................................................... 143

Quadro 16 - Dados coletados relativos aos executivos .................................. 144

Quadro 17 - Dados coletados relativos às empresas...................................... 144

Quadro 18 - Verbas remuneratórias conforme o padrão CVM ....................... 166

Quadro 19 - Verbas remuneratórias conforme o padrão SEC ........................... 169

Quadro 20 - Verbas remuneratórias dos executivos ingleses .......................... 172

Quadro 21 - Variáveis da correlação canônica - Brasil ................................... 211

Quadro 22 - Variáveis da correlação canônica - Estados Unidos...................... 214

Quadro 23 - Variáveis da correlação canônica - Inglaterra .............................. 216 


\section{LISTA DE TABELAS}

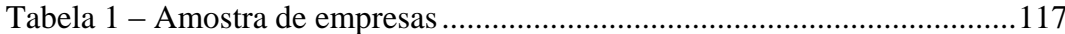

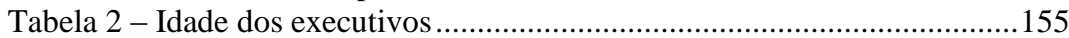

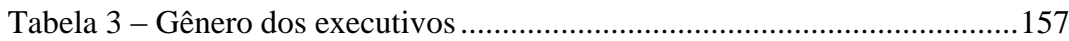

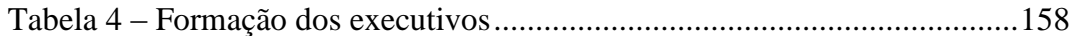

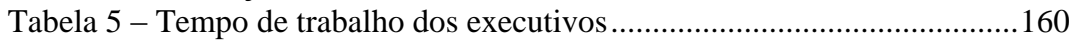

Tabela 6 - Segmento de atuação das empresas .................................................162

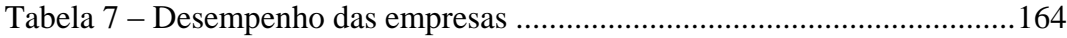

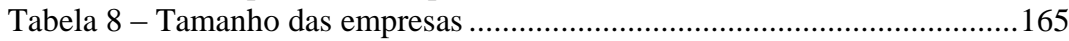

Tabela 9 - Política de remuneração dos executivos brasileiros .........................167

Tabela 10 - Política de remuneração dos executivos estadunidenses................170

Tabela 11 - Política de remuneração dos executivos ingleses............................173

Tabela 12 - Subvariáveis do modelo GRAO DVGA - Brasil ............................177

Tabela 13 - Coeficientes do modelo GRAO DVGA - Brasil .............................178

Tabela 14 - Estatística descritiva do GRAO DVGA - Brasil ............................179

Tabela 15 - Subvariáveis do modelo GRAO NP - Brasil...................................181

Tabela 16 - Coeficientes do modelo GRAO NP - Brasil .................................182

Tabela 17 - Estatística descritiva do GRAO NP - Brasil..................................182

Tabela 18 - Subvariáveis do modelo GRAO DVGA - Estados Unidos ............183

Tabela 19 - Coeficientes do modelo GRAO DVGA - Estados Unidos.............184

Tabela 20 - Estatística descritiva do GRAO DVGA - Estados Unidos.............186

Tabela 21 - Subvariáveis do modelo GRAO NP - Estados Unidos...................187

Tabela 22 - Coeficientes do modelo GRAO NP - Estados Unidos ...................188

Tabela 23 - Estatística descritiva do GRAO NP - Estados Unidos ...................189

Tabela 24 - Subvariáveis do modelo GRAO DVGA - Inglaterra......................190

Tabela 25 - Coeficientes do modelo GRAO DVGA - Inglaterra ......................191

Tabela 26 - Estatística descritiva do GRAO DVGA - Inglaterra ......................192

Tabela 27 - Subvariáveis do modelo GRAO NP - Inglaterra .............................193

Tabela 28 - Coeficientes do modelo GRAO NP - Inglaterra............................194

Tabela 29 - Estatística descritiva do GRAO NP - Inglaterra.............................195

Tabela 30 - Estatística descritiva subv. das accruals agregadas - BRA...........199

Tabela 31 - Coeficientes do modelo de accruals agregadas - BRA ..................201

Tabela 32 - Accruals discricionárias - BRA..................................................201

Tabela 33 - Estatística descritiva subv. das accruals agregadas - EUA...........202

Tabela 34 - Coeficientes do modelo de accruals agregadas - EUA..................203

Tabela 35 - Accruals discricionárias - EUA.....................................................204

Tabela 36 - Estatística descritiva subv. das accruals agregadas - ING ...........205

Tabela 37 - Coeficientes do modelo de accruals agregadas - ING .................206

Tabela 38 - Accruals discricionárias - ING....................................................206

Tabela 39 - Índice de Gini adaptado - BRA, EUA e ING................................209

Tabela 40 - Correlações canônicas entre a PRE e o GR - BRA .........................212

Tabela 41 - Coeficientes do modelo de correlação canônica - BRA.................213

Tabela 42 - Correlações canônicas entre PRE e GR - EUA...............................214

Tabela 43 - Coeficientes do modelo de correlação canônica - EUA.................215 
Tabela 44 - Correlações canônicas entre PRE e GR - ING ………………...... 216

Tabela 45 - Coeficientes do modelo de correlação canônica - ING ................. 217

Tabela 46 - Remuneração em dinheiro dos executivos e ger. resultados ....... 224

Tabela 47 - Correlações canônicas PRE e GR (variáveis endógenas) - BRA 228

Tabela 48 - Correlações canônicas PRE e GR (variáveis endógenas) - EUA 231

Tabela 49 - Correlações canônicas PRE e GR (variáveis endógenas) - ING . 234 


\section{SUMÁRIO}

1 INTRODUÇÃO ....................................................................................17

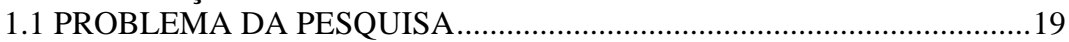

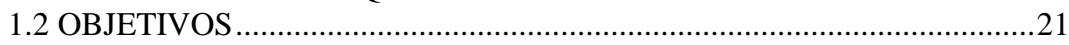

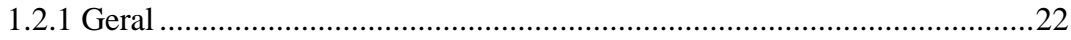

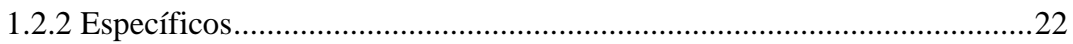

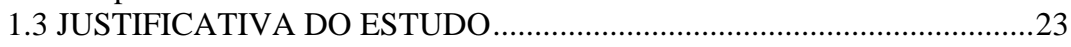

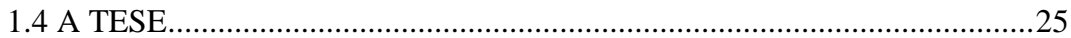

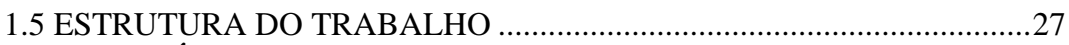

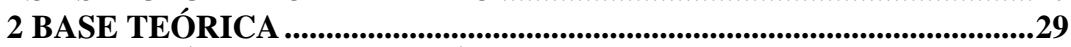

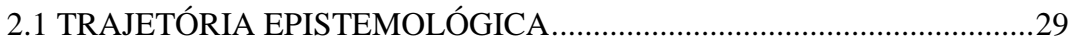

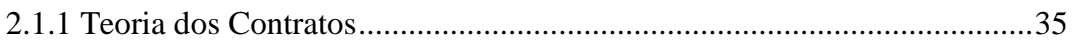

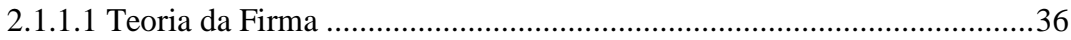

2.1.1.2 Teoria dos Direitos de Propriedade........................................................37

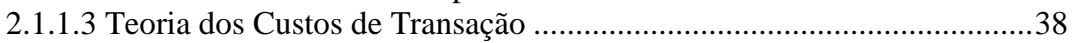

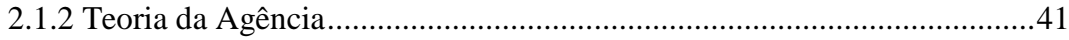

2.1.2.1 Custos de Agência ..................................................................................

2.1.2.2 Mecanismos de Monitoramento.............................................................45

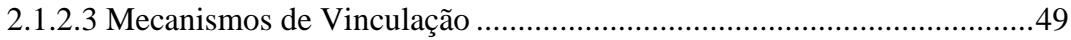

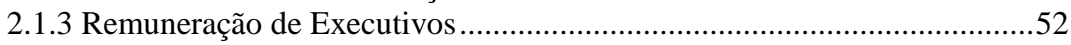

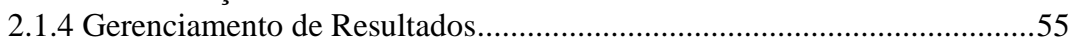

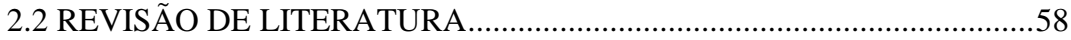

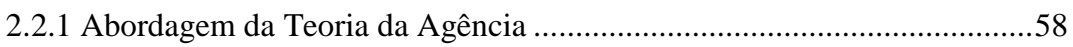

2.2.2 Elementos da Remuneração de Executivos ...............................................60

2.2.2.1 Componentes de Remuneração..............................................................60

2.2.2.2 Políticas de Remuneração ....................................................................64

2.2.2.3 Regulamentação da Evidenciação da Remuneração .................................65

2.2.2.4 Estudos Anteriores - Remuneração de Executivos...................................66

2.2.3 Aspectos do Gerenciamento de Resultados .............................................73

2.2.3.1 Padrões de Gerenciamento de Resultados .............................................79

2.2.3.2 Incentivos para o Gerenciamento de Resultados ...................................82

2.2.3.3 Modelos de Mensuração ........................................................................ 85

2.2.3.4 Estudos Anteriores - Gerenciamento de Resultados e Remuneração de

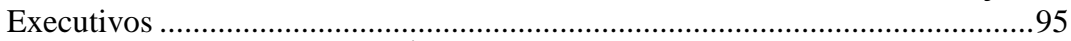

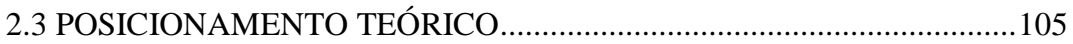

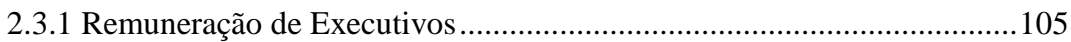

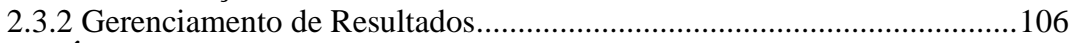

3 MÉTODO E PROCEDIMENTOS DA PESQUISA ..................................108

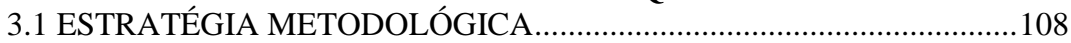

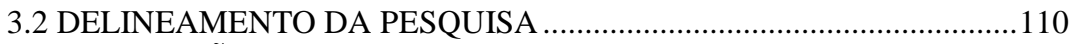

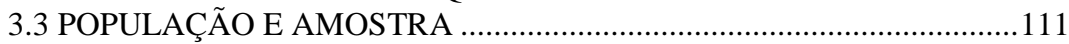

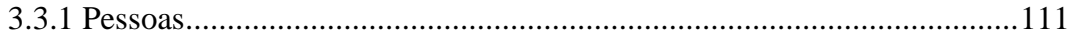

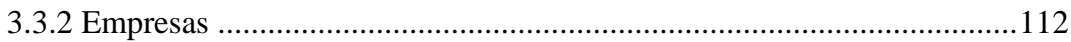

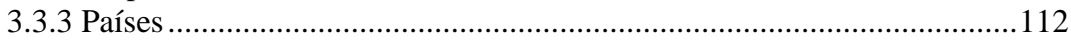




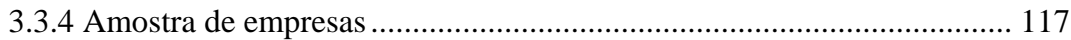

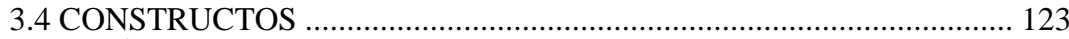

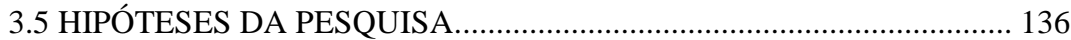

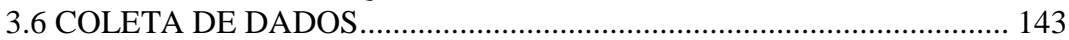

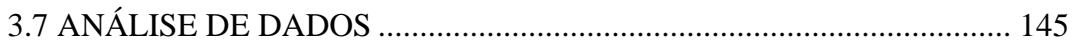

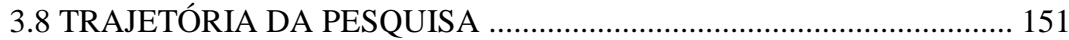

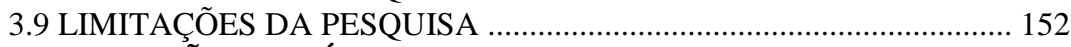

4 DESCRIÇÃO E ANÁLISE DOS RESULTADOS ....................................... 154

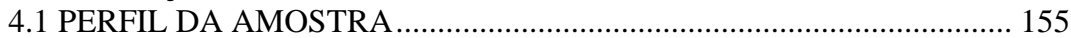

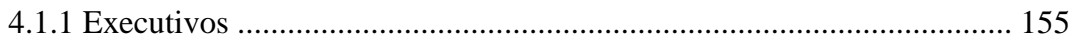

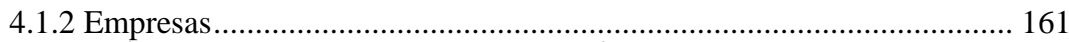

4.2 POLÍTICAS DE REMUNERAÇÃO - NÍVEL E ESTRUTURA .............. 166

4.2.1 Empresas Industriais Brasileiras ........................................................ 166

4.2.2 Empresas Industriais Estadunidenses................................................. 168

4.2.3 Empresas Industriais Inglesas .......................................................... 171

4.2.4 Análise conjunta do BRA, EUA e ING para a Política de Remuneração dos executivos nas Perspectivas de Nível e Estrutura .................................... 174 4.3 NÍVEIS DE GERENCIAMENTO DE RESULTADOS NAS ATIVIDADES

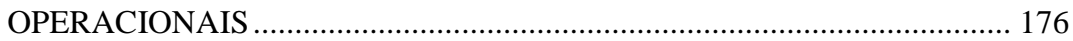

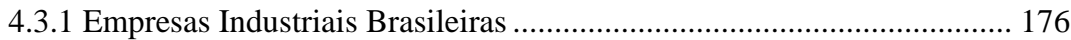

4.3.2 Empresas Industriais Estadunidenses.................................................. 183

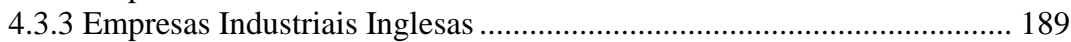

4.3.4 Análise conjunta do BRA, EUA e ING para os Níveis de Gerenciamento de Resultados nas Atividades Operacionais.................................................... 195 4.4 NÍVEL DE GERENCIAMENTO DE RESULTADOS NAS ACCRUALS

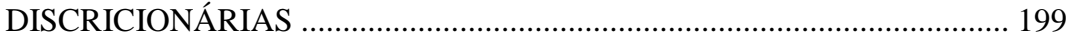

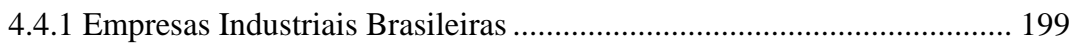

4.4.2 Empresas Industriais Estadunidenses.................................................. 202

4.4.3 Empresas Industriais Inglesas ............................................................ 204

4.4.4 Análise conjunta do BRA, EUA e ING dos Níveis de Gerenciamento de Resultados nas Accruals Discricionárias ........................................................ 207

4.5 POLÍTICA DE REMUNERAÇÃO DOS EXECUTIVOS VERSUS NÍVEL DE GERENCIAMENTO DE RESULTADOS ............................................ 210

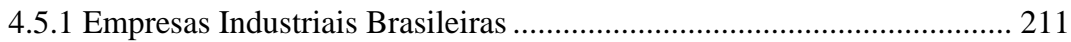

4.5.2 Empresas Industriais Estadunidenses.................................................. 213

4.5.3 Empresas Industriais Inglesas ........................................................... 216

4.5.4 Análise conjunta do BRA, EUA e INGL para a Política de Remuneração dos Executivos versus Nível de Gerenciamento de Resultados ...................... 218 4.6 ANÁLISE DA POLÍTICA DE REMUNERAÇÃO E NÍVEL DE GERENCIAMENTO DE RESULTADOS COM VARIÁVEIS ENDÓGENAS

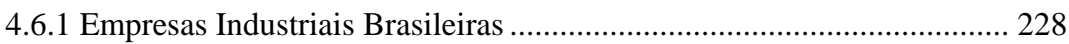

4.6.2 Empresas Industriais Estadunidenses................................................... 230

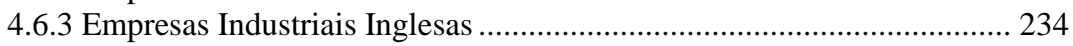


4.6.4 Análise conjunta do BRA, EUA e ING para a Política de Remuneração dos Executivos e do Gerenciamento de Resultados com a amostra segregada pelas Variáveis Endógenas ...........................................................................2236

5 CONCLUSÕES E RECOMENDAÇÕES..............................................243

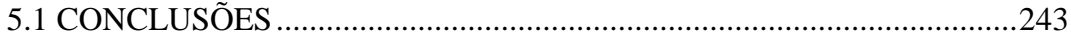

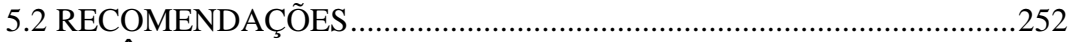

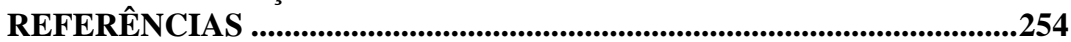




\section{INTRODUÇÃO}

O plano de remuneração do diretor executivo (Chief Executive Officer - CEO) baseado em desempenho indica que a sua remuneração aumenta quando a riqueza dos acionistas aumenta (JENSEN; MURPHY, 1990). De acordo com Baber, Janakiraman e Kang (1996), existe forte associação entre a remuneração do executivo e o desempenho da empresa com maiores oportunidades de investimentos. Smith Jr. e Watts (1992) identificaram fortes relações empíricas entre os dividendos e a escolha da política de remuneração. Com base no exposto, subentende-se que a política de remuneração se constitui em importante mecanismo de incentivo para que o executivo busque acrescer sua riqueza e a da empresa.

O CEO tem a responsabilidade geral pelo desempenho da empresa e, portanto, é suscetível a tomar decisões sobre reestruturar as operações da empresa (DECHOW; HUSON; SLOAN, 1994). O nexo de relações entre analistas, investidores e conselhos gera fortes incentivos para os executivos gerenciarem os resultados, pois o padrão de lucros divulgados é de interesse fundamental para as decisões de investimentos (DEGEORGE; PATEL; ZECKHAUSER, 1999). Os CEOs compreendem como suas ações afetam os lucros contábeis (MURPHY, 1999), logo são os principais gerenciadores dos resultados contábeis.

Havendo gerenciamento de resultados, os resultados contábeis são geridos por meio de proxies que mensuram as accruals discricionárias (MCNICHOLS; WILSON, 1988). Estas são entendidas como a diferença entre o resultado divulgado e o fluxo de caixa das operações. Os modelos analíticos de gerenciamento de resultados têm confrontado incentivos exógenos e de comunicação entre principal e agente (SCHIPPER, 1989).

Os modelos utilizados para estimar as accruals totais normais permitem que alterações nas mudanças econômicas alterem as accruals discricionárias (JONES, 1991). Assim, as proxies de gerenciamento de resultados se equivalem a diferença entre o lucro ou prejuízo do período e o valor do fluxo de caixa das operações das empresas. Os modelos de mensuração são direcionados à análise de incentivos externos e de divulgação que envolvem o principal e o agente. Também, que as accruals discricionárias são influenciadas pelas mudanças econômicas.

Internamente as escolhas contábeis podem ser influenciadas pelo desempenho financeiro da empresa (DECHOW; SLOAN; SWEENEY, 1995), pelos covenants ou restrições contratuais (DEFOND; JIAMBALVO, 1994), pelas dificuldades financeiras da 
empresa (DEANGELO; DEANGELO; SKINNER, 1994), pelas regulamentações contábeis (DECHOW; SLOAN; SWEENEY, 1995), pelo smoothness, ou seja, pelo interesse em amenizar a variabilidade dos resultados contábeis (BURGSTAHLER; DICHEV, 1997), pela oferta inicial de ações (TEOH; WELCH; WONG, 1998) e pela padronização contábil (HEALY; WAHLEN, 1999).

O gerenciamento de resultados contábeis por meio de atividades operacionais utiliza-se de diferentes elementos, como: a gestão do fluxo de caixa operacional (FRANKEL, 2005), os descontos nos preços para aumentar temporariamente as vendas, a superprodução para relatar menor custo das mercadorias vendidas, a redução de despesas discricionárias para melhorar as margens (GUNNY, 2005; ROYCHOWDHURY, 2005), as implicações de decisões de absorção de custos de produção (GUPTA; PEVZNER; SEETHAMRAJU, 2005), o investimento em pesquisa e desenvolvimento para aumentar o resultado, o prazo de reconhecimento da receita, a eliminação de ativos de longa duração (GUNNY, 2005).

Zang (2005) verificou que empresas que manipulam seus resultados por meio de atividades operacionais utilizam menos manipulação por meio de accruals discricionárias. Outro aspecto observado por Cohen e Zarowin (2008) é que após o advento da Lei Sarbanes-Oxley (SOX) as empresas têm utilizado mais a manipulação de resultados contábeis por meio de atividades operacionais do que por meio de accruals discricionárias. Cohen e Zarowin (2008) também constataram que a oferta sazonal de ações influencia as empresas a recorrerem à manipulação de atividades operacionais.

Sobre a influência da remuneração dos executivos no gerenciamento de resultados, pesquisas de Healy (1983, 1985) indicaram que os executivos remunerados com plano de bônus selecionam procedimentos contábeis que aumentem a sua remuneração. Lambert e Larcker (1987) constataram que a remuneração do executivo em dinheiro, ou seja, salário mais bônus anual, possui forte relação com o retorno sobre o patrimônio líquido da empresa. Por sua vez, Gaver e Gaver (1993) ressaltam que há evidências sobre a relação entre o conjunto de oportunidades de investimento e financiamento, de dividendos, e as políticas de remuneração de executivos. Depreende-se do exposto que a política de remuneração do executivo está associada à prática de gerenciamento de resultados por meio de escolhas contábeis.

Segundo Sloan (1993), a inclusão de medidas de desempenho baseadas em lucros, nos contratos de remuneração dos executivos, fornece evidências para apoiar a hipótese de que os ganhos refletem 
alterações no valor das ações. Baber, Kang e Kumar (1998) constataram que a sensibilidade da remuneração em dinheiro do executivo varia diretamente com a persistência do lucro, sendo que esta é maior para os casos em que os executivos estão se aproximando da aposentadoria. De acordo com Gaver e Gaver (1998), a remuneração em dinheiro do executivo é significativa e positivamente relacionada com resultados acima da meta, enquanto estes forem positivos, sendo que os mesmos se originam de operações extraordinárias, de operações descontinuadas ou de itens não recorrentes. Deste modo, reforça-se a ideia de que a remuneração dos executivos possui relação com os resultados contábeis.

Tendo por background que a política de remuneração do executivo é um importante mecanismo de incentivo para a prática discricionária de gerenciamento de resultados, por meio de escolhas contábeis ou por manipulação de atividades operacionais, encaminha-se a problematização do tema, evidenciando os achados de pesquisas anteriores e a lacuna que emerge dessas.

\subsection{PROBLEMA DA PESQUISA}

Dentre os usuários da informação contábil incluem-se o principal (proprietário) e o agente (gestor). O agente utiliza informações contábeis para a tomada de decisões, e de acordo com seus interesses faz escolhas contábeis, como forma de efetivar a prática de gerenciamento de resultados, na expectativa de recompensas por seu desempenho (HEALY; WAHLEN, 1999).

Este tipo de atitude pode ser associada à ideia de manipulação dos resultados, e se apresenta como uma problemática, visto que as escolhas contábeis feitas pelos gestores de forma intencional possuem reflexos em benefícios particulares. Essa visão oportunística tem implicação no contexto desta pesquisa, que se volta para o estudo das motivações contratuais, expostas por Schipper (1989), inseridas no contexto do gerenciamento de resultados, mais especificamente, no contrato entre principal e agente.

Quanto às motivações contratuais, um dos incentivos para a prática de gerenciamento de resultados advém dos contratos entre principal e agente. Por meio dos mecanismos de vinculação descritos na teoria da agência, a remuneração do executivo se constitui num desses mecanismos de redução de conflitos e de assimetria informacional (JENSEN; MECKLING, 1976).

A política de remuneração dos executivos é um incentivo para a prática de gerenciamento de resultados e pode se efetivar por meio de 
atividades operacionais, por accruals discricionárias ou por ambos (HEALY, 1985; SCHEAPPER, 1989; HANLON; RAJGOPAL; SHEVLIN, 2003; BARTOV; MOHANRAM, 2004; GUNNY, 2005; ZANG, 2005; LAUX; LAUX, 2009).

A remuneração dos executivos tem sido estudada de forma associada com o gerenciamento de resultados por accruals discricionárias. Pesquisas têm sido desenvolvidas com a associação do gerenciamento de resultados e a remuneração por meio de bônus (GUIDRY; LEONE; ROCK, 1999; HEALY, 1999); também com a remuneração baseada em ações (ABBODY; KASZNIK, 2000; BENS et al., 2003); ainda, com a remuneração em dinheiro (COMPRIX; MULLER, 2006).

Isoladamente ambos os temas também tem sido objeto de estudo. A remuneração dos executivos foi pesquisada nas perspectivas de nível e estrutura, relacionando práticas de diversos países (MURPHY, 1999). O gerenciamento de resultados por meio de atividades operacionais foi pesquisado em empresas industriais Americanas, por meio da base de dados COMPUSTAT, com foco nas despesas discricionárias de pesquisa e desenvolvimento de novos produtos, bem como dos níveis de produção, relacionando as escolhas contábeis à gestão de estoques e a política de vendas (GUNNY, 2005; ROYCHOWDHURY, 2005; ZANG, 2005).

A disseminação da remuneração dos executivos se tornou recorrente nos Estados Unidos da América (EUA) (MURPHY, 1999). Por meio da mídia tem havido divulgação de diversas pesquisas anuais, a exemplo da Forbes (2009) e do The Wall Street Journal (2009). A remuneração passou a ser evidenciada no país desde 1938 (MURPHY, 1999). Também tem havido expressiva produção científica sobre o tema (SOUZA; BORBA, 2007). Os Estados Unidos influenciaram a remuneração dos executivos brasileiros por meio das empresas norteamericanas instaladas no Brasil (NUNES; MARQUES, 2005).

No Brasil, as empresas passaram a evidenciar a remuneração dos executivos a partir da Instrução Normativa n ${ }^{\circ} 480$ da CVM, de 7 de dezembro de 2009, retroagindo ao ano de 2007. É escassa a produção científica publicada em periódicos brasileiros de contabilidade sobre a remuneração do executivo com o gerenciamento de resultados (MACHADO; BENETTI; BEZERRA, 2011). Assim, se torna relevante alavancar pesquisas sobre a remuneração dos executivos, em particular a partir do ano de 2007.

No Reino Unido da Grã-Bretanha e Irlanda do Norte, que representa a união política da Inglaterra, Escócia, Irlanda do Norte e 
País de Gales, comumente denominada de Reino Unido (United Kingdom - UK), pesquisas sobre a remuneração dos executivos demonstraram que houve redução do nível de remuneração na década de 90 (HAYNES; THOMPSON; WRIGHT, 2007; MURPHY; SANDINO, 2010). Esta redução passou a ser percebida porque a evidenciação da remuneração se consolidou nesta mesma década (GREENBURY, 1995). A divulgação favoreceu o acesso aos dados necessários para ampliação de pesquisas científicas sobre a temática (HAYNES; THOMPSON; WRIGHT, 2007). Pesquisa realizada por Ederhof (2011) revelou semelhança entre a remuneração de gestores de nível médio do UK, incluindo a Inglaterra, e dos EUA. Outra constatação empírica foi que empresas do UK, semelhante as dos EUA, têm incentivos para gerenciar resultados (IQBAL; STRONG, 2010).

A partir das pesquisas citadas observam-se diversas lacunas de pesquisa que sugerem relacionar a remuneração dos executivos: a) segregada como na proposição de Murphy (1999), com o gerenciamento de resultados; b) com o gerenciamento de resultados por meio de atividades operacionais; c) com o gerenciamento de resultados por meio de atividades operacionais e accruals discricionárias. Também é interessante relacionar a remuneração dos executivos com o gerenciamento de resultados por atividades operacionais em empresas industriais de diversos países, como se propõe neste estudo, em específico do Brasil, Estados Unidos e Inglaterra.

Isso permite comparar os dois últimos países, com a política de remuneração de executivos em estágios mais avançados de consolidação, com o Brasil, que passou a regulamentar a evidenciação da política de remuneração de executivos de empresas brasileiras, por meio da entrada em vigor da Instrução Normativa nº 480 da CVM.

Com base no exposto elaborou-se a seguinte pergunta de pesquisa: Qual a influência da política de remuneração dos executivos no nível de gerenciamento de resultados sob a ótica das escolhas contábeis por meio de atividades operacionais e accruals discricionárias em empresas industriais brasileiras, estadunidenses e inglesas?

\subsection{OBJETIVOS}

A delimitação estrita dos objetivos de pesquisa direciona a mesma para as especificidades dos métodos utilizados (BRUYNE; HERMAN; SCHOUTHEETE, 1977). Desta forma, os objetivos de pesquisa visam direcionar a operacionalização da pesquisa, apontando o caminho a ser percorrido. 


\subsubsection{Geral}

O objetivo geral é identificar a influência da política de remuneração dos executivos no nível de gerenciamento de resultados sob a ótica das escolhas contábeis por meio de atividades operacionais e accruals discricionárias em empresas industriais brasileiras, estadunidenses e inglesas.

\subsubsection{Específicos}

De forma a contribuir no alcance do objetivo geral foram elaborados os seguintes objetivos específicos:

a) identificar a política de remuneração dos executivos nas perspectivas de nível e estrutura, conforme a proposição de Murphy (1999), de empresas industriais brasileiras, estadunidenses e inglesas, no período de 2007 a 2010;

b) estimar o nível normal de gerenciamento de resultados a partir das atividades operacionais das empresas pesquisadas, no período de 2007 a 2010, considerando as despesas com vendas, gerais e administrativas pelo modelo de Anderson, Banker e Janakiraman (2003); as despesas com Pesquisa e Desenvolvimento (P\&D) pelo modelo de Gunny (2005); e o nível de produção pelo modelo de Roychowdhury (2005);

c) estimar o nível normal de gerenciamento de resultados das empresas pesquisadas, no período de 2007 a 2010, a partir das accruals discricionárias pelo modelo de Dechow, Sloan e Sweeney (1995);

d) analisar a relação da política de remuneração dos executivos com o nível de gerenciamento de resultados, por meio das atividades operacionais e das accruals discricionárias, das empresas objeto do estudo, no período de 2007 a 2010;

e) analisar a relação da política de remuneração dos executivos e do nível de gerenciamento de resultados, com as características de idade, expertise e gênero dos executivos e das características de homogeneidade, desempenho e tamanho das empresas. 


\subsection{JUSTIFICATIVA DO ESTUDO}

O tema remuneração do executivo é amplamente divulgado na literatura contábil. Dentre os autores da temática destaca-se o plano de remuneração atrelado: aos mecanismos de incentivos (JENSEN; MURPHY, 1990), ao desempenho da empresa (SMITH JR.; WATSS, 1992; BABER; JANAKIRAMAN; KANG, 1996), aos prêmios por meio de incentivos financeiros (DECHOW; HUSON; SLOAN, 1994), além da comparação entre o plano de remuneração de diversos países (MURPHY, 1999).

O tema gerenciamento de resultados, apesar de intensamente pesquisado na América do Norte, Ásia e Europa, não possui ainda no Brasil publicação volumosa em periódicos. Conforme Martinez (2001), Cardoso (2005) e Machado, Benetti e Bezerra (2011), esta ainda necessita de fomento para consolidação no ambiente brasileiro. As publicações brasileiras iniciaram pela tese de Martinez (2001), ao pesquisar o gerenciamento de resultados em companhias abertas brasileiras.

$\mathrm{Na}$ literatura estrangeira, dentre os autores seminais, têm-se pesquisas sobre o gerenciamento de resultados, por meio de accruals discricionárias, em relação: aos rendimentos decrescentes (MCNICHOLS; WILSON, 1988), aos tipos de gerenciamentos (SCHIPPER, 1989), aos modelos de mensuração de accruals (JONES, 1991; DECHOW; SLOAN; SWEENEY, 1995), aos covenants contratuais (DEFOND; JIAMBALVO, 1994), às dificuldades financeiras das empresas (DEANGELO; DEANGELO; SKINNER, 1994), às violações de Generally Accepted Accounting Principles (GAAPs) (DECHOW; SLOAN; SWEENEY, 1996), ao smoothness (BURGSTAHLER; DICHEV, 1997), à oferta inicial de ações (TEOH; WELCH; WONG, 1998), aos limiares da prática de gerenciamento (DEGEORGE; PATEL; ZECKHAUSER, 1999), à padronização contábil (HEALY; WAHLEN, 1999), ao processo de convergência às normas contábeis internacionais do International Accounting Standards Board (IASB), e às diferentes percepções (DECHOW; SKINNER, 2000).

Sobre o gerenciamento de resultados, por meio de atividades operacionais, têm-se na literatura estudos em relação: às despesas discricionárias com vendas, gerais e administrativas (ANDERSON; BANKER; JANAKIRAMAN, 2003), à gestão do fluxo de caixa operacional (FRANKEL, 2005; ROYCHOWDHURY, 2005), ao novo quadro teórico do gerenciamento de resultados (YAPING, 2005), às 
consequências da manipulação de atividades reais (GUNNY, 2005) e às implicações de decisões de absorção de custos de produção (GUPTA; PEVZNER; SEETHAMRAJU, 2005).

O gerenciamento de resultados por meio de accruals discricionárias e de atividades operacionais tem sido pesquisado por Zang (2005), Cardoso e Martinez (2006) e Martinez (2011). Também, destas relações com a oferta sazonal de ações por Cohen e Zarowin (2008). Depreende-se que a relação entre o gerenciamento de resultados por meio de atividades operacionais e accruals discricionárias se constitui em um tema arfante para novas pesquisas.

Unindo os dois temas, a política de remuneração e o gerenciamento de resultados, dentre as obras mais citadas destacam-se as pesquisas com relação: ao plano de bônus (HEALY, 1983, 1985), às ações gerenciais (LAMBERT; LARCKER, 1987; GAVER; GAVER, 1993), aos ganhos contábeis (SLOAN, 1993), à persistência de lucro (BABER; KANG; KUMAR, 1998) e aos reflexos de ganhos e perdas na remuneração em dinheiro (GAVER; GAVER, 1998).

Denota-se que há lacunas ainda não preenchidas por pesquisas científicas. Uma destas lacunas se constitui no aspecto inovador desta tese, que se traduz em pesquisar as relações entre a política de remuneração dos executivos, segregada como na proposição de Murphy (1999), com o gerenciamento de resultados por meio de atividades operacionais e accruals discricionárias, simultaneamente, em empresas industriais brasileiras, estadunidenses e inglesas.

Pesquisas anteriores na área de gerenciamento de resultados indicam que a gestão de resultados é uma realidade nas organizações (HEALY, 1985; SCHEAPPER, 1989; BURGSTAHLER; DICHEV, 1997; DECHOW; SKINNER, 2000; MARTINEZ, 2001; GUNNY, 2005; BERGSTRESSERA; PHILIPPON, 2006; COHEN; ZAROWIN, 2008; BASIRUDDIN, 2011). Por outro lado, nota-se que existem incentivos para o gestor efetivar as escolhas contábeis, em razão do seu plano de remuneração estar atrelado aos números contábeis (HEALY, 1985; DEANGELO, 1986; SHIPPER, 1989).

A motivação para investigar a influência da política de remuneração do executivo no nível do gerenciamento de resultados em empresas do Brasil, dos Estados Unidos da América e da Inglaterra decorre da: disseminação expressiva de pesquisas sobre a remuneração dos executivos nos Estados Unidos (MURPHY, 1999, SOUZA; BORBA, 2007); escassa produção científica sobre o tema na Inglaterra (HAYNES; THOMPSON; WRIGHT, 2007); baixa representatividade de pesquisas no Brasil (NUNES; MARQUES, 2005). Adicionalmente, 
das diferenças no tempo de evidenciação da remuneração dos executivos nos Estados Unidos (MURPHY, 1999), na Inglaterra (GREENBURY, 1995) e no Brasil (IN no 480 CVM, 2009). Também, da influência dos Estados Unidos nas pesquisas sobre a remuneração dos executivos realizada na Inglaterra (EDERHOF, 2011) e na remuneração de executivos brasileiros (NUNES; MARQUES, 2005).

O período de 2007 a 2010 é importante para a evidenciação da remuneração dos executivos brasileiros, pois a Instrução Normativa $n^{\circ}$ 480 CVM, que entrou em vigor em 2009, exigiu a evidenciação dos últimos três exercícios sociais, ou seja, 2007, 2008 e 2009. Portanto, a partir de 2007 foi possibilitada a realização de pesquisas com estas informações (SILVA, 2010).

Por se constituir em pesquisa empírica, que se utilizou de informações contábeis de empresas industriais, a contribuição desta tese, para além da academia, alcança os usuários da informação contábil, pois conforme Yaping (2005), as demonstrações financeiras das empresas são a principal forma de comunicação do valor da firma, do desempenho para os acionistas e para outras partes interessadas. Também, em aspectos da prática profissional, representa uma aproximação da teoria desenvolvida no ambiente acadêmico e da prática das organizações em relação ao seu processo decisório refletido nas ações do agente e, consequentemente, nas demonstrações contábeis. O estudo também contribui para fomentar a discussão acadêmica sobre as ações organizacionais e seus reflexos nos resultados contábeis.

\subsection{A TESE}

A prática de gerenciamento de resultados é incentivada pelos conflitos de agência, existentes nos contratos entre principal e agente (JENSEN; MECKLING, 1976; SCHIPPER, 1989). Os contratos, que são pré-determinados entre o principal e o agente, estão expostos à racionalidade limitada e ao oportunismo gerencial (WILLIAMSON, 1985). Assim, as informações contábeis são utilizadas para monitorar e regular os contratos.

A remuneração do agente, por sua vez, é utilizada como incentivo para alinhar os interesses entre o principal e o agente (SHLEIFER; VISHNY, 1997; HEALY; WAHLEN, 1999). A remuneração do executivo se constitui em um mecanismo de vinculação entre principal e agente, na medida em que, por meio de monitoramento e vínculos, busca mitigar os problemas de agência (JENSEN; MECKLING, 1976; BARNEY; HESTERLY, 2004). 
O plano de remuneração incentiva a prática de gerenciamento de resultados (HEALY, 1983, 1985; LAMBERT; LARCKER, 1987; GAVER; GAVER, 1993). À luz da Teoria da Agência, tendo o plano de remuneração de executivos como mecanismo de redução de conflitos entre principal e agente, e ao mesmo tempo como incentivo para as práticas oportunísticas do agente, formula-se a tese de que a política de remuneração dos executivos influencia o nível de gerenciamento de resultados, por meio de atividades operacionais ou por accruals discricionárias.

A originalidade da tese está em vislumbrar a relação entre a política de remuneração e o nível de gerenciamento de resultados, por atividades operacionais e por accruals discricionárias. Também pelo fato de ser inovador estudar gerenciamento de resultados nas duas modalidades, por atividades operacionais e accruals discricionárias, relacionando-as com a remuneração do executivo. Ainda, por explorar empiricamente o Brasil, os Estados Unidos da América e a Inglaterra.

Para a remuneração dos executivos utilizou-se o modelo de mensuração de Murphy (1999). Na mensuração do nível de gerenciamento de resultados por meio de atividades operacionais utilizou-se: para as despesas com vendas, gerais e administrativas o modelo de Anderson, Banker e Janakiraman (2003); para as despesas com P\&D o modelo de Gunny (2005); e para o nível de produção o modelo de Roychowdhury (2005). Para a mensuração do nível de gerenciamento de resultados por meio de accruals discricionárias, utilizou-se o modelo de Dechow, Sloan e Sweeney (1995).

A escolha da proposição de Murphy (1999) se deve a completude com que o autor trata a remuneração dos executivos na perspectiva de nível e estrutura. O modelo de Anderson, Banker e Janakiraman (2003), por permitir estimar o gerenciamento de resultados por meio de despesas discricionárias. O modelo de Gunny (2005), por possibilitar estimar o gerenciamento de resultados por despesas com pesquisa e desenvolvimento, atividade relevante para as empresas industriais. O modelo de Roychowdhury (2005), por permitir estimar os níveis de produção para empresas industriais. O modelo de Dechow, Sloan e Sweeney (1995) por ser o mais utilizado em pesquisas internacionais de periódicos com alto fator de impacto, para mensuração do gerenciamento de resultados por meio de accruals discricionárias. 


\subsection{ESTRUTURA DO TRABALHO}

O trabalho está dividido em cinco capítulos, que estão interligados. Este capítulo inicial apresenta a contextualização do tema investigado, o problema de pesquisa, os objetivos geral e específicos, a justificativa e contribuições do estudo, a tese e a organização estrutural do trabalho.

No capítulo dois é apresentada a teoria de suporte ao estudo. Primeiramente expõe-se a trajetória epistemológica da teoria dos contratos, da teoria da agência, da remuneração de executivos e do gerenciamento de resultados. Em seguida apresenta-se a revisão de literatura, que faz um resgate contemporâneo da teoria da agência, da remuneração de executivos e do gerenciamento de resultados. Por fim, discorre-se sobre o posicionamento teórico adotado para a pesquisa no que concerne à remuneração de executivos e ao gerenciamento de resultados.

O capítulo três define o método e as técnicas de pesquisa empregadas. Apresenta primeiramente a estratégia metodológica que define o espaço metodológico abrangido pelo estudo. Em seguida expõe o delineamento da pesquisa. Após discorre sobre a população e a amostra do estudo distribuída em pessoas, empresas, período e países. $\mathrm{Na}$ sequência exibe os constructos, que evidenciam a operacionalização dos objetivos específicos da pesquisa; as hipóteses de pesquisa, relacionadas ao gerenciamento de resultados, à remuneração em dinheiro e às variáveis endógenas (características dos executivos e das empresas). Seguem-se os procedimentos de coleta de dados relativos a remuneração dos executivos e aos dados contábeis. Em seguida apresenta a forma de análise dos dados, em atendimento aos objetivos da pesquisa. Demonstra também a trajetória de execução e as limitações da pesquisa.

No capítulo quatro apresentam-se a descrição e análise dos resultados. Inicia-se pelo perfil da amostra. Segue-se a política de remuneração dos executivos nas perspectivas de nível e estrutura. Após expõem-se os níveis de gerenciamento de resultados a partir das atividades operacionais, despesas com vendas, gerais e administrativas, despesas com pesquisa e desenvolvimento e níveis de produção. $\mathrm{Na}$ sequência, evidenciam-se o gerenciamento de resultados por meio das accruals discricionárias. Em seguida apresentam-se as relações da política de remuneração dos executivos com os níveis de gerenciamento de resultados, além das análises da relação entre a política de remuneração dos executivos e o gerenciamento de resultados, com a 
amostra segregada por variáveis endógenas (a) do executivo (idade, expertise e gênero) e (b) da empresa (segmento, desempenho e porte).

No capítulo cinco estão expostas as conclusões da pesquisa realizada e recomendações para estudos futuros sobre o tema investigado. Ao final encontram-se as referências utilizadas no aporte teórico, de pesquisas anteriores, de normatização dos temas tratados e de dados coletados para a execução deste trabalho. 


\section{BASE TEÓRICA}

A base teórica desta tese compreende a trajetória epistemológica das teorias utilizadas como suporte para a pesquisa, a revisão de literatura contendo um framework conceitual e estudos anteriores dos temas abordados, e por fim, o posicionamento teórico adotado para a realização do estudo.

A trajetória epistemológica localiza o aporte teórico da pesquisa dentre os paradigmas de análise da teoria social. Inicia-se com a trajetória da teoria dos contratos e da teoria da agência. A teoria dos contratos, com ênfase na teoria da firma, na teoria dos direitos de propriedade e na teoria dos custos de transação. Em seguida aborda a trajetória da teoria da agência e destaca os tópicos que apresentam características essenciais para a sua compreensão. $\mathrm{Na}$ sequência apresenta a trajetória epistemológica da remuneração de executivos e do gerenciamento de resultados.

A revisão de literatura inicia com a exposição da teoria da agência em seus aspectos contemporâneos. Em seguida aborda a remuneração de executivos, conceituando a segregação e a política da mesma. Estudos anteriores nacionais e internacionais complementam este subitem. Após apresenta o gerenciamento de resultados em seus aspectos conceituais, propósitos, incentivos, modelos de mensuração e estudos anteriores.

O posicionamento teórico abrange a seleção dos modelos para a mensuração da remuneração dos executivos e do gerenciamento de resultados por meio de atividades operacionais e de accruals discricionárias.

\subsection{TRAJETÓRIA EPISTEMOLÓGICA}

$\mathrm{Na}$ análise da teoria, que procura examinar como os teóricos tentam compreender seu objeto de estudo, a partir de um marco de referência, na medida em que pressupostos são afirmados e reafirmados de forma contínua pelos cientistas da área, se faz necessário compreender, na teoria das organizações, a relação entre os modos específicos de teorização e pesquisa e as visões de mundo que elas refletem (MORGAN, 1980). Desta forma, torna-se relevante situar a pesquisa no campo epistêmico, ou seja, o campo propriamente científico, pois quando satisfeita esta condição, a integralidade das exigências metodológicas será respeitada e a integridade dos 
pesquisadores será protegida das determinações e coerções exteriores à prática científica (BRUYNE; HERMAN; SHOUTEETE, 1977).

Burrel e Morgan (1979) estruturaram, a partir de duas dimensões conceituais básicas, a sociologia e a teoria organizacional, "[...]dois eixos que, ao serem colocados em ângulo reto, criam quatro paradigmas, mutuamente excludentes" (BURREL, 1998, p. 447). Esses compreendem a dimensão subjetiva/objetiva, a natureza da sociedade, a dimensão da mudança por regulação ou por via radical (BURREL; MORGAN, 1979).

O termo paradigma veio para dentro da análise organizacional de forma articulada por meio da publicação do livro intitulado Sociological Paradigms and Organizational Analysis de Burrel e Morgan em 1979. Os autores tiveram papel relevante na popularização e aceitação de tradições teóricas críticas e interpretativas na teoria organizacional, também na produção de diálogos interparadigmáticos (CALDAS, 2007).

O conceito preciso de paradigma não está claro, o termo dá ideia de leis clássicas e modos de vida comunitária (BURREL, 1998). Para Burrel (1998, p. 447), paradigmas definem "uma forma de ver o mundo e como este deveria ser estudado", e este ponto de vista é compartilhado por um grupo de cientistas que vivem em uma comunidade marcada por uma linguagem conceitual comum. Para Morgan (1979 citado por MORGAN 1980, p. 606), paradigma denota uma visão implícita ou explícita da realidade, e ressalta que:

a fim de compreender a natureza da ortodoxia na organização da teoria, é necessário entender a relação entre os modos específicos de teorização e pesquisa e as visões de mundo que elas refletem. O conceito de paradigma tem sido objecto de uma ampla e confusa faixa de interpretação pelos teóricos.

Para Burrel e Morgan (1979), o papel dos paradigmas, como visões de realidade social, denotam que a teoria social em geral e a teoria das organizações em particular poderiam ser utilmente analisadas em quatro amplas visões de mundo, que são representadas em diferentes conjuntos de pressuposições metateóricas ou epistemiológicas sobre a natureza da ciência.

Cada um dos paradigmas coexistiria na análise organizacional, a partir de uma série de posições epistemológicas e ontológicas de base, formando posições metateóricas a priori no desenvolvimento científico. 
A ideia é que o campo científico cresceria em reflexidade e riqueza se os quatro distintos paradigmas pudessem se reconhecer e eventualmente dialogar (CALDAS, 2007). Na Figura 1 apresenta-se o mapa que descreve os quatro paradigmas utilizados pelos teóricos e os quadros de referências adotados.

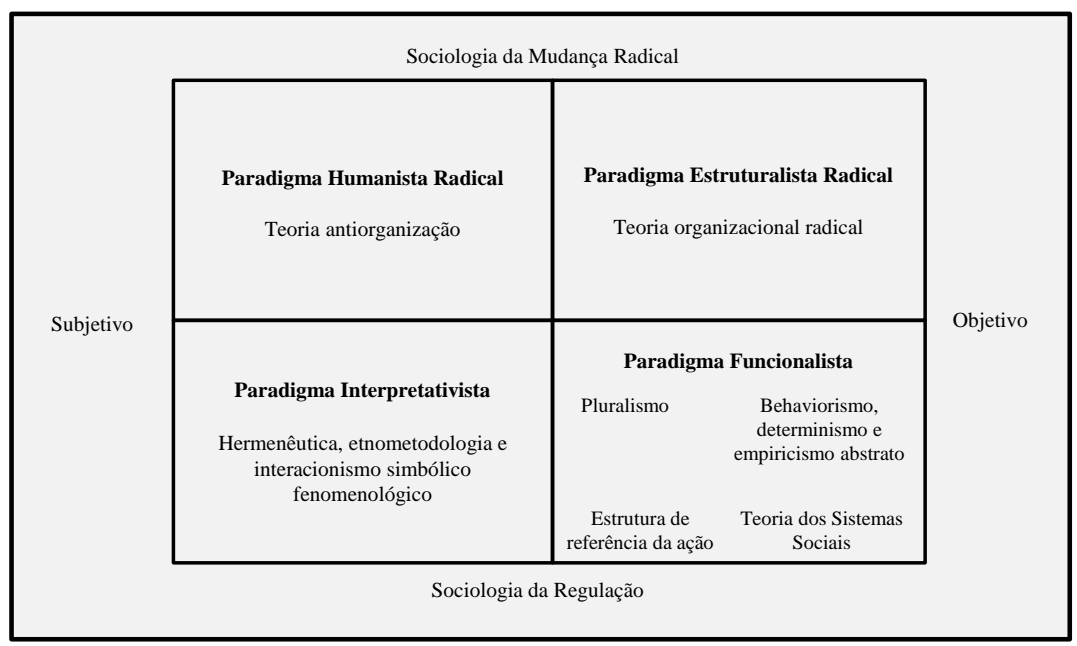

\section{Figura 1 - Paradigmas para análise da teoria social}

Fonte: Burrel e Morgan (1979).

Na Figura 1, observam-se os quatro paradigmas utilizados para análise da teoria social: o funcionalista, o interpretativista, o humanista radical e o estruturalista radical. Cada um representa uma rede de escolas de pensamento inter-relacionadas, diferentes em abordagem e perspectiva, mas que compartilham pressupostos fundamentais sobre a natureza da realidade de que tratam (BURREL; MORGAN, 1979).

Os quatro paradigmas, tomados em conjunto, fornecem um mapa que oferece uma maneira de identificar similaridades básicas e diferenças no trabalho dos vários teóricos e, em particular, os quadros de referência subjacentes que eles seguem. Como qualquer outro mapa, ele se constitui em uma ferramenta para estabelecer onde se está, onde se esteve e para onde é possível ir no futuro. Um fato que merece atenção é que os quatro paradigmas são mutuamente exclusivos, pois eles oferecem pontos de vista alternativos sobre a realidade social (BURREL; MORGAN, 1979).

O paradigma humanista radical é definido por sua inquietação em desenvolver a sociologia da mudança radical, de um ponto de vista 
subjetivista. Sua abordagem à ciência social considera o mundo social a partir de uma perspectiva nominalista, antipositivista, voluntarista e ideográfica. Seu quadro de referência tem o compromisso com uma visão da sociedade que enfatiza a importância de extinguir ou de transcender as limitações dos arranjos sociais existentes. Uma das noções mais básicas subjacentes a este paradigma é a de que a consciência do homem é dominada pelas superestruturas ideológicas com o qual ele interage, e que estas dirigem uma cunhagem cognitiva entre ele e a sua verdadeira consciência (BURREL; MORGAN, 1979, p.32).

No paradigma do estruturalismo radical os teóricos defendem uma sociologia da mudança radical sob o ponto de vista objetivista. É comprometido com a mudança radical, com a emancipação e com a potencialidade, em uma análise que enfatiza o conflito estrutural, os modos de dominação e de privação. Se aproxima a uma inquietação geral do ponto de vista que tende a ser realista, positivista, determinista e nomotética. Os estruturalistas radicais se concentram nas relações estruturais dentro de um mundo de realismo social (BURREL; MORGAN, 1979, p. 33-34).

Teóricos localizados no contexto do paradigma interpretativista adotam uma abordagem consoante com os princípios da sociologia da regulação. O paradigma interpretativo é formado por uma inquietação de compreender o mundo como ele é, ao nível da experiência subjetiva. Busca explicação dentro do reino da consciência individual, da subjetividade, do quadro de referência do participante ao contrário do observador da ação. $\mathrm{Na}$ sua abordagem à ciência social tende a ser nominalista, antepositivista, voluntarista e ideográfico. Ele vê o mundo social como um processo social emergente, que é criado por indivíduos envolvidos. A realidade social não tem qualquer existência fora da consciência de qualquer indivíduo, é considerada como sendo pouco mais do que uma rede de pressupostos e significados compartilhados intersubjetivamente (BURREL; MORGAN, 1979, p. 28 e 31).

$\mathrm{O}$ paradigma funcionalista forneceu a estrutura dominante para a condução da sociologia acadêmica e do estudo das organizações. Ele representa uma perspectiva que está enraizada firmemente na sociologia da regulação e seu contexto se aproxima do ponto de vista objetivista. É caracterizado por uma inquietação de fornecer explicações sobre $o$ status quo, da ordem social, do consenso, da integração social, da solidariedade, da necessidade de satisfação e atualização. Aborda estas inquietações sociológicas gerais sob o ponto de vista que tende a ser 
realista, positivista, determinista e nomotética (BURREL; MORGAN, 1979, p. 25).

O paradigma funcionalista, em sua abordagem global procura fornecer essencialmente uma explicação racional dos assuntos sociais. É altamente pragmático, é orientado para fornecer soluções concretas para problemas práticos. É geralmente e firmemente comprometido com a filosofia de engenharia social como base para a mudança social, enfatizando a importância de entender a ordem, o equilíbrio e a estabilidade na sociedade e a maneira como estes podem ser mantidos. Está envolvido com a regulação eficaz e o controle dos assuntos sociais (BURREL; MORGAN, 1979, p. 26).

Ainda na Figura 1 tem-se a sociologia da mudança radical e a sociologia da regulação, e uma se contrapõe a outra. A primeira abrange os paradigmas humanista e estruturalista radical e a última os paradigmas interpretativista e funcionalista.

A sociologia da mudança radical é a sociologia interessada essencialmente na emancipação do homem e de suas estruturas, que limitam e impedem seu potencial de desenvolvimento. É frequentemente visionária e utópica, naquilo que olha como potencialidade, muito mais do que como realidade presente. Dentro do contexto da sociologia da mudança radical tem havido uma divisão entre os teóricos que adotam os pontos de vista: subjetivo e objetivo da sociedade (BURREL; MORGAN, 1979).

Por sua vez, o termo sociologia da regulação, segundo Burrel e Morgan (1979), refere-se aos escritos dos teóricos que estão primordialmente interessados em prover explanações da sociedade em termos que enfatizam sua unidade subjacente e coesa, ou seja, é uma sociologia essencialmente interessada na necessidade de regulação dos afazeres humanos.

Johansson e Woodilla (2008) destacam que há muitas maneiras de dividir as teorias organizacionais, pois os estudiosos reconhecem que as diversas escolas de pensamento coexistem, embora tenham se originado em diferentes contextos históricos. Ao contemplar as explicações dos quatro paradigmas para análise da teoria social, seguindo a abordagem de Burrel e Morgan (1979), esta tese, em termos teóricos, se enquadra no paradigma funcionalista, assumindo que esta enfatiza que as organizações e seus membros podem orientar suas ações e comportamentos pelo propósito de atingir estados futuros.

Apoiado nas definições dos paradigmas propostas por Burrel e Morgan (1979), especificamente no paradigma funcionalista, a seguir descreve-se a trajetória epistemológica da teoria dos contratos, da teoria 
da agência, da remuneração de executivos e do gerenciamento de resultados, com o propósito de fornecer a orientação pragmática dos quadros de referência subjacentes que os pesquisadores do tema seguem. A partir da síntese da trajetória epistemológica que fundamenta esta tese, demonstrada na Figura 2, com seus autores principais, seguese a exposição teórica da mesma.

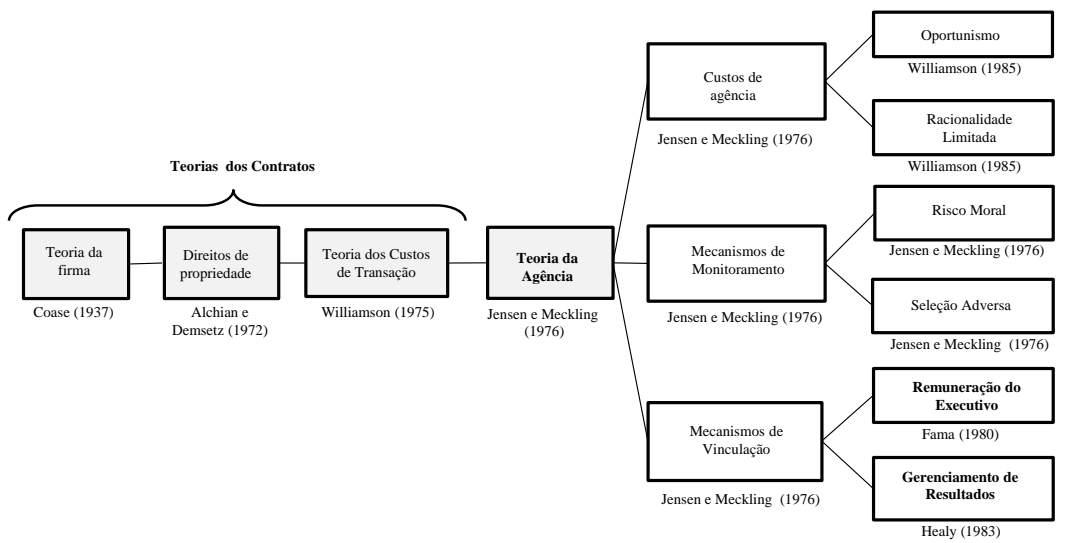

Figura 2 - Síntese da trajetória epistemológica que fundamenta esta tese

Fonte: Elaboração própria.

Observa-se na Figura 2 o desenvolvimento cronológico dos temas tratados na seção 2.1 da tese. Inicia-se com as teorias dos contratos, que abrange a teoria da firma de Coase (1937), em que surgem as relações contratuais. Seguem-se as contribuições da teoria dos direitos de propriedade de Alchian e Demsetz (1972), com relação ao monitoramento para avaliação do desempenho das partes envolvidas no contrato. Após, consta a teoria dos custos de transação de Williamson (1975), que inclui a complexidade nas relações contratuais. A lacuna de desenvolvimento teórico entre 1940 e 1970, segundo Williamson (1985), se deve ao período de desenvolvimento tecnológico das empresas.

As teorias dos contratos são precursoras da teoria da agência, que se formalizou por Jensen e Meckling (1976) e trata das relações de agência, em que o foco central é o principal e o agente e os conflitos de interesses existentes entre ambos. A teoria da agência explica os custos de agência, os efeitos dos mecanismos de monitoramento e de vinculação nas relações de agência. 
Os custos de agência incluem os pressupostos comportamentais de Williamson (1985) relativos ao oportunismo e à racionalidade limitada existentes nos contratos, porque os mesmos são incompletos e os agentes imperfeitos. Os mecanismos de monitoramento expostos por Jensen e Meckling (1976) incluem os problemas de assimetria informacional, que abrangem os contextos de risco moral e seleção adversa. Por fim, os mecanismos de vinculação incluem nas relações contratuais, por meio dos incentivos para alinhamento de interesses entre principal e agente, o plano de remuneração dos agentes (FAMA, 1980). Dos mecanismos de vinculação surge também o gerenciamento de resultados, que por meio das escolhas e ações organizacionais leva o agente a gerenciar os números contábeis atrelados a sua remuneração (HEALY, 1983).

\subsubsection{Teoria dos Contratos}

A literatura sobre a teoria dos contratos abrange uma área multidisciplinar (ZYLBERSZTAJN, 2005). Para esta pesquisa buscouse a teoria da firma e sua extensão, abrangendo a teoria dos direitos de propriedade e a teoria dos custos de transação.

A ligação entre a teoria geral dos contratos e a economia dos custos de transação, ou teoria dos custos de transação, foi estabelecida por Williamson (1985). Juntas, elas constituem a sequência da teoria da firma. A primeira explica as condições em que as transações econômicas podem ser mais eficientemente gerenciadas, usando formas hierárquicas de governança. A segunda explica as ligações entre as diferentes transações.

A ligação entre a teoria da firma e a teoria dos custos de transação envolve o impacto da remuneração, o controle corporativo, a estrutura de capital e outros atributos da governança da firma, que exercem pressão sobre os problemas de agência, tanto no interior da firma, como entre a firma e os diversos stakeholders envolvidos (BARNEY; HESTERLY, 2004).

De acordo com Barney e Hesterly (2004), a teoria dos contratos é composta por três essências principais, embora tenha sofrido influências multidisciplinares, como as teorias organizacionais de forma geral, são elas: a teoria da firma, a teoria dos direitos de propriedade e a teoria dos custos de transação. 


\subsubsection{Teoria da Firma}

Conforme Llewellyn (1931), o estudo do contrato e da contrapartida legal subsidia o estudo da organização econômica. Coase (1937) é o autor reconhecido como responsável pela criação da teoria da firma e na época destacou que o estudo interno e de mercado externo da organização não são desconexos, mas são uteis dentro de um framework comum, economizando custos de transação. $\mathrm{O}$ autor evidenciou que os mercados não operam sem custos e se fundamenta no custo de usar os mercados com a finalidade de formar contratos para enunciar sua explicação básica para a existência das firmas. Surge então a concepção de que a firma é um nexo de contratos. Coase (1937) incluiu a incerteza nos contratos, em que o agente assume riscos em troca de remuneração.

Segundo Barney e Hesterly (2004), para Coase (1937), a razão das organizações existirem é que o custo de gerenciar transações econômicas, por meio de mercados pode ser maior do que o custo de gerenciá-las dentro dos limites da organização. O custo de usar o sistema de preços envolve atividades do tipo: a descoberta de quais são os preços, a negociação e a renegociação dos contratos, a monitoração e a resolução de conflitos. A principal contribuição de Coase (1937), conforme Barney e Hesterly (2004, p. 133), foi a de "colocar os custos de transação no centro da questão da existência das firmas e sugerir que mercados e organizações são alternativas para gerenciar as transações".

Barnard (1938) estudou as funções do executivo na época em que os teóricos estavam preocupados com os princípios da administração, colocando a cooperação em um espaço importante da teoria da organização. Simon (1947) explicou a tese sobre o comportamento administrativo do estudo de Barnard, desenvolvendo um vocabulário mais preciso no processo de análise da racionalidade. Coase (1952) propôs que as empresas e os mercados fossem meios alternativos de organização econômica.

Coase (1972, p. 63) admite que o trabalho elaborado por ele, intitulado "The Nature of the firm, foi muito citado, mas pouco utilizado". A não utilização residiu na dificuldade de operacionalizar seu enfoque nas transações, dificultando a identificação de quais transações deveriam ser deixadas para o mercado e quais transações deveriam ser internalizadas nas firmas. Essas dificuldades foram trabalhadas em um modelo mais completo do custo de usar o mercado para gerenciar transações econômicas, que ficou conhecido como teoria dos custos de transações (BARNEY; HESTERLY, 2004). 
Para Williamson (1975), mercados e hierarquias são instrumentos alternativos para completar um conjunto de transações, estes também são denominados de mecanismos de governança. Williamson (1985) menciona que há um hiato entre 1940 e 1970 na teoria dos contratos, pois neste período desenvolveram-se características tecnológicas da empresa e da organização de mercado.

As organizações têm buscado a formalização da proposição fundamental de Adam Smith, difundida em seu livro 'A Riqueza das Nações'. Esta pressupõe que a economia pode ser coordenada por um sistema descentralizado de preços, planejando ajustes quando necessário. Esse esforço é chamado de teoria da firma (DEMSETZ, 1990). Conforme Williamson (1985), firmas, mercados e relações contratuais são importantes instituições econômicas.

Após o trabalho seminal de Coase, que postula sobre a teoria da firma, a próxima contribuição relevante, conforme Barney e Hesterly (2004), se origina da teoria dos direitos de propriedade.

\subsubsection{Teoria dos Direitos de Propriedade}

Coase (1972) amplia as discussões sobre as transações. Nos direitos de propriedade, a cooperação, a mensuração e a avaliação de desempenho que se traduziu no monitoramento, e a renegociação de contratos foram objetos de estudo de Alchian e Demsetz (1972). A teoria dos direitos de propriedade é a primeira extensão do pensamento de Coase (1937) e representa a ênfase dada por Alchian e Demsetz (1972) nos problemas de mensuração como razão para a existência das firmas. Para os autores, a essência da firma clássica é identificada como uma estrutura contratual de renegociação contínua entre os agentes e os proprietários da organização.

Para os autores, a firma não é organizada e gerida autoritariamente, mas por meio de trocas voluntárias, permitindo a supervisão dos processos de produção em equipe e dos gerentes pelos acionistas, aumentando a eficiência da organização, da produção em equipe e a redução da ociosidade. A interdependência entre os membros do grupo dificulta a avaliação da contribuição de cada um. Desta forma, são necessários mecanismos de monitoração e mensuração do esforço de cada membro da equipe, para que seja possível remunerá-los adequadamente (ALCHIAN; DEMSETZ, 1972).

Conforme Barney e Hesterly (2004), a firma surge para atender a necessidade de monitorar os esforços das pessoas que formam uma equipe. Monitorando cada um, reduz-se a probabilidade de evasão do 
trabalho. Como as pessoas são designadas para monitorar funções, resulta daí uma hierarquia que dá organização à firma. Como monitorar tem um custo, é eficiente monitorar apenas até o ponto em que os benefícios de redução da ociosidade se igualem aos custos marginais de monitoramento.

Suprida a necessidade de monitoração do desempenho das pessoas de uma equipe, surge outro problema. Quem deve monitorar o monitor? Como ocorre com os demais membros da equipe, o monitor tem um incentivo para ficar ocioso, a menos que incentivos contrários existam (ALCHIAN; DEMSETZ, 1972). A solução apontada pelos autores é de que o monitor deve arcar com os custos de sua própria ociosidade, conferindo-lhe o direito de negociar e renegociar contratos com todos os membros da equipe, de monitorar seus esforços produtivos, e depois que todos os membros da equipe tiverem sido remunerados, poderá exigir o eventual valor residual. O monitor, então, paga os membros da equipe baseado em suas produtividades individuais e guarda para si a porção restante como salário. Esse acordo garante ao monitor forte incentivo para monitorar os esforços de cada membro da equipe. Os resultados serão menores incentivos para a ociosidade e maiores para aumento da produtividade (BARNEY; HESTERLY, 2004).

O enfoque dado por Alchian e Demsetz (1972) explica as hierarquias gerenciais e a existência de acionistas como reclamantes dos valores residuais das firmas. No entanto, algumas questões importantes da natureza da firma estão ocultas nesse enfoque da produção em equipe. O trabalho de Williamson (1975) busca complementar as razões para existência das organizações, que são consideradas como o núcleo da economia ou teoria dos custos de transação (BARNEY; HESTERLY, 2004).

Após a contribuição expressiva de Alchian e Demsetz (1972) para o monitoramento do desempenho das pessoas de uma equipe, Williamson (1975) proporciona o entendimento dos pressupostos comportamentais que envolvem as partes contratantes nas transações econômicas.

\subsubsection{Teoria dos Custos de Transação}

A complexidade dos contratos foi enfatizada por Williamson (1975), por meio da teoria dos custos de transação, que se apoia em dois pressupostos comportamentais fundamentais acerca dos atores econômicos engajados em transações: a racionalidade limitada e o 
oportunismo. Segundo Williamson (1975), os contratos tornam-se incompletos em decorrência destes fatores. A racionalidade limitada indica que aqueles que estão envolvidos nas transações econômicas são intencionalmente racionais, mas apenas de modo limitado (SIMON, 1947). Sem limites cognitivos, todas as transações poderiam ser conduzidas por meio de planejamento (WILLIAMSON, 1985).

De acordo com Williamson (1975), as pessoas poderiam escrever contratos de complexidade ilimitada que especificariam todas as contingências possíveis numa transação econômica. Entretanto, devido à racionalidade limitada, contratos complexos desaparecem diante da incerteza, ou seja, ante a previsão de eventualidades. Já o oportunismo representa a busca do interesse próprio com astúcia.

Para Williamson (1985), o oportunismo inclui mentir, roubar e trapacear, mas isso geralmente refere-se a uma relação incompleta ou distorcida de informações, especificamente voltada a esforços para enganar, alterar, disfarçar, ou de outra maneira, confundir parceiros numa transação. A teoria dos custos de transação não considera todos os atores econômicos sempre oportunistas, mas que alguns desses atores podem se comportar de forma oportunista, também que há um custo para distinguir os que são propensos ao oportunismo e os que não o são. Dada essa situação é recomendável projetar salvaguardas para as pessoas e as firmas a fim de que não sejam vítimas uns dos outros.

Barney e Hesterly (2004) destacam que os atores econômicos precisam estar preocupados com os problemas criados pela racionalidade limitada e pelo oportunismo e com o custo de governar as transações econômicas. A incerteza, presente nos problemas da racionalidade limitada, pressupõe que, quanto maior o grau de incerteza numa transação, mais difícil será o uso de contratos e outras estruturas de governança de mercado, levando a que se adotem estruturas hierárquicas de governança.

Outro fator presente nos problemas de racionalidade limitada é o investimento específico da transação. O nível de investimento alocado a uma transação tem maior relevância do que a incerteza e as formas hierárquicas de governança. A existência de investimentos específicos aumenta a ameaça de oportunismo, pois haverá possibilidades de escolhas entre diversas opções de investimentos. Quanto maior for o nível de investimento específico, maior será a ameaça do oportunismo. Quanto maior for a ameaça do oportunismo, menor a probabilidade de a governança de mercado reduzir efetivamente essa ameaça (BARNEY; HESTERLY, 2004). 
As aplicações da teoria dos custos de transação, conforme Williamson (1985), envolvem a integração vertical e a forma multidivisionalizada. A primeira, sob o enfoque da teoria dos custos de transação, utiliza a transação como nível de análise, já a última diz respeito à estrutura hierárquica da firma, organizada para que contribua na solução dos problemas operacionais gerados na firma a serem resolvidos pelos administradores. A teoria dos custos de transações explica porque as organizações existem, mas falha em explicar de que maneira os diversos atores concordam sobre as metas, a suposição implícita nesta teoria é de que o acordo relativo à forma de gerenciamento não é problemático.

No entanto, o fato de os parceiros de transações econômicas estarem mutuamente interessados em formar uma organização não significa que suas diferenças de interesses, gostos e preferências deixem de existir (WILLIAMSON, 1985). Na Figura 3 apresentam-se os autores expoentes e suas principais contribuições para a teoria dos contratos.

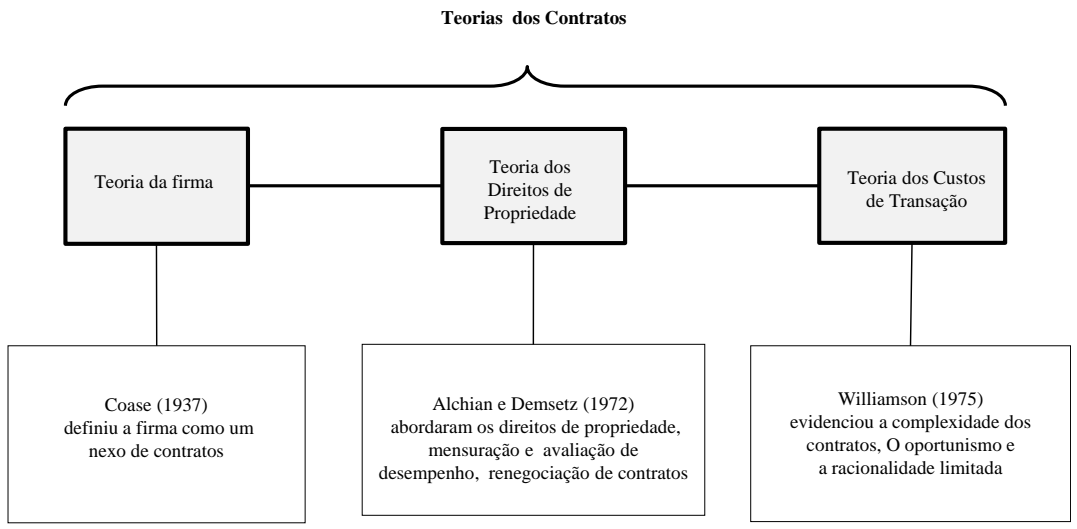

Figura 3 - Síntese da trajetória epistemológica da teoria dos contratos

Fonte: Elaboração própria.

Em síntese, a teoria dos contratos teve as contribuições de Coase (1937) na visão da firma como um nexo de contratos; de Alchiam e Demsetz (1972), ao tratarem sobre os direitos de propriedade, que destacaram a relevância do monitoramento entre as partes contratantes que transacionam, em razão dos problemas de mensuração, de avaliação de desempenho e de renegociação destes, com foco na remuneração das partes; e nos pressupostos comportamentais de Williamson (1975), que 
evidenciou a complexidade dos contratos, dado a racionalidade limitada como a incompletude dos contratos e o oportunismo como problema de agência, necessitando de monitoramento, pois todos os contratos são incompletos.

A literatura diverge em determinados momentos, quando apresenta a sequência epistemológica de desenvolvimento da teoria dos contratos e da teoria da agência. Sobre a teoria dos contratos, conforme Fama (1980), os antecedentes do trabalho de Alchian e Demsetz (1972) e de Jensen e Meckling (1976) são os de Coase (1937) e (1952).

Sobre a teoria da agência, de acordo com Fama e Jensen (1983), a separação da propriedade e controle inicia por Adam Smith e segue com Bearle e Means (1932) e Jensen e Meckling (1976). Segundo Eisenhardt (1989), os precursores são Wilson (1968) e Ross (1973). Para Caldas e Cunha (2007), a teoria da agência nasce dos trabalhos pioneiros de Coase (1937), Alchian e Demsetz (1972) e Williamson (1975). A seguir, apresenta-se o desenvolvimento da teoria da agência até o momento da sua efetiva formalização.

\subsubsection{Teoria da Agência}

O trabalho de Berle e Means (1932), publicado na obra The Modern Corporation and Private Property, já debatia os inevitáveis conflitos de interesse que estruturas de propriedade pulverizadas poderiam acarretar para o desempenho e valor das companhias, embora a discussão não estivesse atrelada a teoria da agência, que teve seus primeiros trabalhos publicados na década de 70 .

Berle e Means (1932) foram os primeiros a discutir os benefícios e custos potenciais da separação entre propriedade e controle já vigente em algumas grandes corporações. Entre os custos potenciais, os autores observaram que a pulverização da propriedade fortaleceria o poder dos gestores, aumentando as chances de os mesmos agirem em seu próprio interesse, e não no interesse dos acionistas.

A sequência deste pensamento reflete-se no trabalho de Coase (1937), que define a existência das relações contratuais, posteriormente chamadas de relações de agência.

Wilson (1968), ao pesquisar um grupo de tomadores de decisões individuais, que tomam uma decisão comum sob incerteza e que, consequentemente, recebe conjuntamente uma recompensa a ser compartilhada entre eles, foi considerado como um dos antecedentes da teoria da agência. A pesquisa referia-se a um sindicado e a seus membros, que possuíam diferentes níveis de tolerância a risco e/ou 
diversificadas percepções sobre a avaliação de probabilidades de acontecimentos incertos que afetam a remuneração.

A similaridade do trabalho de Spence e Zeckhauser (1971) com a futura teoria da agência está no momento em que os autores, ao analisarem diferentes casos de seguros, discutem o tamanho da remuneração a ser paga aos segurados e a quantidade de informações que a seguradoras estavam dispostas a monitorar.

Com relação ao monitoramento, a teoria da agência é fortemente influenciada pela literatura dos direitos de propriedade de Alchian e Demsetz (1972) e, em menor extensão, pelos próprios custos de transação. A primeira trata do funcionamento das relações contratuais e a última da dinâmica destas relações que se estabelecem entre as partes contratantes.

Para Ross (1973), a relação de agência é um dos modos codificados mais antigos e mais comuns de interação social. Segundo o autor, uma relação de agência surge entre duas ou mais partes quando uma parte, designada de agente, atua para a outra parte, designada de principal, em um domínio específico de problemas decisórios. Assim, o agente atua em nome do principal ou como representante do mesmo.

Os conflitos de interesses pertencentes à separação entre propriedade e controle foram pesquisados por Zeitlin (1974). O objetivo era estudar o impacto desta separação em grandes corporações, incluindo os conflitos de classe, os processos políticos, a dominação social e a mudança histórica.

Assim formaliza-se a teoria da agência por Jensen e Meckling (1976). Em seu desenvolvimento original, esta focalizava a relação entre os gestores e os acionistas. Nesta formatação esta teoria foi muito utilizada para analisar o controle das corporações, incluindo questões como o papel do corpo diretivo e a remuneração dos administradores de cúpula. A teoria da agência tem sido aplicada nas relações entre os diversos stakeholders da firma. Os conflitos advindos dessas relações têm importantes repercussões organizacionais sobre a governança corporativa, a estrutura e os sistemas de remuneração (BARNEY; OUCHI, 1986).

O trabalho de Jensen e Meckling (1976) apresentou três contribuições principais: a) a criação de uma teoria de estrutura de propriedade das companhias baseada nos inevitáveis conflitos de interesses individuais e com predições testáveis empiricamente; b) a definição de um novo conceito de custos de agência, mostrando sua relação com a separação entre propriedade e controle presente nas empresas; e c) a elaboração de uma nova definição da firma, 
descrevendo-a como mera ficção legal, que serve como elo para um conjunto de relacionamentos contratuais entre os indivíduos (BARNEY; HESTERLY, 2004).

A teoria da agência é a parte da literatura econômica que busca compreender as causas e consequências, para as organizações, da discordância sobre metas (BARNEY; HESTERLY, 2004). Entretanto, a teoria da agência e a teoria dos custos de transação, apesar de estarem voltadas para a teoria da organização, possuem vertentes distintas. A primeira trata primordialmente das relações contratuais delegativas, onde incentivos e controles são fundamentais; a segunda trata da eficiência do contrato e não do desenho contratual ex-ante (ZYLBERSTAJN, 1995).

A necessidade de delegação de autoridade, por parte do principal para o agente é uma das premissas primordiais da teoria da agência que aporta os custos de agência, que podem ser mitigados pelos mecanismos de monitoramento e vinculação.

\subsubsection{Custos de Agência}

Como a teoria dos custos de transação, a teoria da agência parte do pressuposto de que os seres humanos têm um limite de racionalidade, são interesseiros e propensos ao oportunismo (EISENHARDT, 1989). As teorias também são similares na ênfase dada aos problemas de assimetria de informação, desde o momento ex-ante até o ex-post da realização de um contrato. Também na eficiência, como principal motivo de buscar uma estrutura de governança para as transações econômicas (BARNEY; OUCHI, 1986). A teoria da agência difere da teoria dos custos de transação em sua ênfase nas atitudes de risco dos proprietários e dos agentes (EISENHARDT, 1989).

Como a relação entre os acionistas e os gestores de uma empresa se enquadra na definição de uma relação de agência pura, surgem problemas associados à separação entre propriedade e controle na corporação, e se constituem no foco central da teoria da agência (JENSEN; MECKLING, 1976).

Há uma divergência natural de interesses entre o agente e o principal. Também existe uma variedade de relações econômicas e sociais envolvidas. Se a informação fluísse sem custo e de forma perfeita, os superiores saberiam o que seus subordinados sabem e o que estão fazendo. Mas, na vida real a informação completa raramente está disponível gratuitamente para todas as partes, e assim este problema embasa a estruturação do acordo, que irá induzir os agentes a servir aos 
interesses do principal, mesmo quando suas ações e informações não são observadas pelo principal (PRATT; ZECKHAUSER, 1985).

Para proteger os interesses do proprietário, esforços são necessários para reduzir a possibilidade de os agentes se comportarem mal no futuro. Nesse esforço, custos são incorridos. Esses custos são chamados de custos de agência. Os custos totais de agência são os de monitoramento dos gastos realizados pelo proprietário, os relativos aos compromissos do agente e as perdas residuais do proprietário. Essa perda residual demonstra que em muitas situações será mais custoso para o proprietário monitorar integralmente o agente e muito custoso para o agente assegurar ao proprietário que os interesses não são divergentes (JENSEN; MECKLING, 1976).

Sobre os custos de agência, Jensen e Meckling (1976, p. 309) mencionam que:

[...] o desenvolvimento de teorias para explicar a forma que os custos de agência assumem em cada uma dessas situações, em que as relações contratuais são significativamente diferentes, e como e porque eles surgem levará a uma riquíssima teoria das organizações, que atualmente inexiste, tanto na economia, como no âmbito das ciências sociais.

A definição de custos de agência de Jensen e Meckling (1976) é próxima do problema de monitoramento em uma equipe de produção levantado por Alchian e Demsetz (1972), na contribuição teórica dada à teoria da firma.

Conforme Pratt e Zeckhauser (1985), considerando as assimetrias de informações, pois agentes tipicamente sabem mais sobre suas tarefas do que os seus diretores, não se pode esperar que a empresa funcionasse tão bem quanto poderia ser se todas as informações fossem compartilhadas e sem custo ou se os incentivos do principal para o agente pudessem ser alinhados sem custo. Entretanto, as partes contratantes têm sido bem sucedidas na estruturação de mecanismos e medidas para enfrentar os problemas de agência.

Partindo do pressuposto que os custos de agência existem, tanto os proprietários quanto os agentes têm um forte incentivo para minimizá-los. Onde for possível estabelecer economias nos custos de agência, esses benefícios podem ser compartilhados entre agentes e proprietários. Assim o proprietário e o agente têm interesse em definir uma estrutura mútua de monitoramento e de incentivos que produza 
efeitos, o mais próximo possível da situação, em que a troca de informação se efetive sem custo (PRATT; ZECKHAUSER, 1985).

Conforme Barney e Hesterly (2004), três questões importantes surgem dos problemas de agência: a) a necessidade de os proprietários delegarem autoridade aos agentes; b) os mecanismos de monitoramento que podem ser implantados para minimizar os problemas de agência; e c) os mecanismos de vinculação que podem ser usados para tranquilizar os proprietários.

A essência, oriunda da teoria dos direitos de propriedade de Alchian e Demsetz (1972), sobre a monitoração de desempenho, passou a ser adequada ao contexto do agente e principal por Jensen e Meckling (1976).

\subsubsection{Mecanismos de Monitoramento}

Conforme a antevisão de Smith de 1776, em Smith (1983), não se pode esperar que os gestores operassem com a mesma vigilância que os proprietários. Assim, surge a necessidade do proprietário de monitorar o gestor.

As relações de agência ocorrem quando um parceiro na transação, proprietário ou principal, delega autoridade a outro, gestor ou agente, e o bem estar do proprietário é afetado pelas escolhas do agente (ARROW, 1985). A delegação de autoridade do proprietário para o agente é problemática à medida que: a) os interesses do proprietário e do agente divergem; b) o proprietário não pode monitorar perfeitamente e sem custo as ações do agente; c) o proprietário não pode monitorar e adquirir a informação disponível ao agente ou por ele possuída de modo perfeito e sem custo.

Tomadas em conjunto essas condições constituem o problema da agência, a possibilidade de comportamento oportunístico por parte do agente que trabalha contra o bem estar do proprietário. Sobre o problema de agência, Jensen e Meckling (1976, p. 309) esclarecem que:

O problema de induzir um agente a comportar-se buscando a maximização do bem estar do acionista pode ser, em princípio, enunciado. Ele existe em qualquer organização, em qualquer esforço cooperativo e em qualquer nível de gestão das firmas.

Eisenhardt (1989) adverte que os problemas contratuais podem ser causados, dentre outros fatores, também pela assimetria 
informacional existente entre principal e agente. De acordo com Arrow (1985) e Milgrom (1987), são duas as fontes essenciais relativas aos problemas de agência: o risco moral (moral hazard), entendido como ações ocultas aos proprietários ou custosas de se observar, e a seleção adversa (adverse selection), considerada como informações ocultas, neste caso o agente possui informações que aos proprietários são inobserváveis. Além de oneroso é praticamente impossível para o proprietário monitorar todas as ações do agente. Em razão destes problemas de agência os proprietários não podem determinar completamente se seus interesses estão sendo tratados da melhor maneira pelas decisões dos agentes.

A seleção adversa é basicamente um problema de assimetria de informação e pode ser reduzida por meio de ganhos com experiência (EISENHARDT, 1989). Para Knight (1965), que tratou do entendimento das ações do homem e da natureza humana, o risco moral e o oportunismo são fatores que envolvem ativamente o estudo da organização econômica. O autor explica que o oportunismo é uma condição sutil e penetrante da natureza humana.

Em empresas maiores e com atividades mais complexas se faz necessária a delegação de autoridade do principal ao agente, e esta implica em custos de agência. Fama e Jensen (1983) mencionam que o processo de tomar a maioria das decisões pode ser dividido em duas grandes categorias:

a) a gestão da decisão, como uma decisão será iniciada e como será supervisionada; e

b) o controle da decisão, como uma decisão é aprovada e como o desempenho será monitorado.

Uma forma de os proprietários tentarem monitorar os agentes é reunindo informações relativamente completas sobre a decisão e a ação de um agente ou sobre o seu comportamento. Com base nessa informação comportamental, os proprietários podem desenvolver julgamentos sobre as metas essenciais e os objetivos dos agentes, comparando com as suas próprias metas e objetivos. No entanto, o monitoramento do comportamento de um agente raramente gerará informação perfeita sobre suas decisões e ações, uma vez que os agentes estão comprometidos com tarefas complexas e altamente estruturadas.

De acordo com Barney e Hesterly (2004), pode ser mais eficaz monitorar o desempenho gerencial ou o resultado individual do agente do que o seu comportamento. Pratt e Zeckhauser (1985) descrevem algumas implicações do monitoramento: 
a) tende-se a reduzir o monitoramento, substituí-lo ou optar por um de menor qualidade quanto este é de alto custo;

b) o monitoramento tende a ser mais intenso quando os interesses ou os valores do principal e agente divergem substancialmente;

c) o ideal seria que as informações e as ações do agente fossem monitoradas. Entretanto, numa gama de situações do mundo real, o monitoramento é limitado;

d) grandes quantias em valores poderiam ser perdidas por mau comportamento, mas a reputação do agente e os bens sob sua responsabilidade, acabam sendo um forte incentivo para o bom comportamento;

e) relacionamentos de agência de longo prazo, entre outros benefícios, desenvolvem um monitoramento mais eficaz;

f) os benefícios de eventuais reduções na perda de agência será compartilhado entre principal e agente na maioria das situações de mercado;

g) o principal e o agente têm interesse comum na definição de uma estrutura de monitoramento e incentivo que produza resultados, o mais próximo possível dos que seriam produzidos se o monitoramento da informação fosse sem custo.

A governança da relação contratual é reconhecida como um mecanismo de monitoramento. Segundo Williamson (1985), esta abrange as tradições contratuais, a governança eficiente, a incerteza, a mensuração e a distribuição das transações. Conforme o autor, as tradições contratuais abrangem o direito contratual clássico, que diz respeito às normas legais, documentos formais do contrato e liquidação das transações. A natureza do acordo contratual é cuidadosamente delimitada e as características formais e informais são planejadas de forma que o mesmo tenha consequências previsíveis desde o início. $\mathrm{O}$ autor explica que as dimensões principais para descrever as transações são especificidades de ativos, incerteza e frequência. A incerteza presente em grau suficiente nos contratos pode requerer uma adaptação, exigência de decisão sequencial, focalização na especificidade dos ativos e frequência.

Para Williamson (1985), os problemas de governança e de mensuração desaparecem se os limites da racionalidade ou o oportunismo estão ausentes. O problema de seleção adversa é uma ilustração de uma condição ex-ante, onde uma parte do contrato tem 
informação privada e pode escolher seletivamente como revelar, e a assimetria a que a outra parte está sujeita não pode superar, exceto a um grande custo. A condição é uma manifestação de um problema mais geral, que é responsável por dificuldades de mensuração de desempenho das partes contratantes, em razão da informação idiossincrática, ou seja, a informação que cada uma das partes possui, individualmente e que não pode ser totalmente revelada a outra parte.

Sobre a distinção entre os papéis de propriedade e gestão da empresa, Masten (1993) destaca que a propriedade é uma condição sustentada por normas legais, possui um status legal de direito aos ativos. Quanto à gestão da empresa, há o relacionamento dos agentes econômicos com os bens, seus direitos e responsabilidades, como definido e apoiado pelo sistema legal. No Quadro 1 tem-se a exposição de algumas dessas variáveis.

\begin{tabular}{|l|l|}
\hline Ideia chave & $\begin{array}{l}\text { O relacionamento do principal-agente pode se refletir na } \\
\text { eficiência organizacional, nos custos da informação e na } \\
\text { assunção de riscos. }\end{array}$ \\
\hline $\begin{array}{l}\text { Unidade de } \\
\text { análise }\end{array}$ & O contrato entre principal e agente \\
\hline $\begin{array}{l}\text { Suposições } \\
\text { pessoais }\end{array}$ & $\begin{array}{l}\text { Interesse próprio } \\
\text { Racionalidade limitada } \\
\text { Aversão ao risco }\end{array}$ \\
\hline $\begin{array}{l}\text { Suposições } \\
\text { organizacionais }\end{array}$ & $\begin{array}{l}\text { Conflito nas metas entre os participantes } \\
\text { Eficiência como critério de eficácia } \\
\text { Assimetria da informação entre principal e agente }\end{array}$ \\
\hline $\begin{array}{l}\text { Suposições } \\
\text { informacionais }\end{array}$ & \begin{tabular}{l} 
Informação como um bem adquirível \\
\hline $\begin{array}{l}\text { Problemas } \\
\text { contratuais }\end{array}$
\end{tabular}$\quad \begin{array}{l}\text { De agência - o risco moral e a seleção adversa } \\
\text { A partilha de riscos }\end{array}$ \\
\hline $\begin{array}{l}\text { Domínio de } \\
\text { problemas }\end{array}$ & $\begin{array}{l}\text { O principal e o agente têm objetivos e preferências, por } \\
\text { risco diferentes. São exemplo: a remuneração, a } \\
\text { regulamentação, a liderança, a divulgação, a integração } \\
\text { vertical e os preços de transferência. }\end{array}$ \\
\hline
\end{tabular}

\section{Quadro 1 - Visão geral da teoria da agência}

Fonte: Eisenhardt (1989, p. 59).

No Quadro 1 observa-se uma visão geral da teoria da agência, exposta por Eisenhardt (1989), que de forma sintetizada expõe as bases desta teoria, com sua ideia central, sua unidade de análise, suas 
suposições pessoais, organizacionais e informacionais, seus problemas e domínios contratuais.

Fama e Jensen (1983) tratam dos mecanismos de monitoramento, da gestão e controle da decisão. Arrow (1985) enumera situações de monitoramento, destacando o risco moral e a seleção adversa como fontes essenciais dos problemas de agência. Pratt e Zeckauser (1985) descrevem situações comuns nas relações de agência que originam os custos de agência. Williamson (1985) destaca que os contratos são incompletos e os agentes são imperfeitos devido ao oportunismo e a racionalidade limitada. Eisenhardt (1985), ao pesquisar a integração de duas perspectivas, a teoria da organização e da economia, particularmente a teoria da agência, se deparou com variáveis de assimetria de informação. Barney e Ouchi (1986) trataram da assimetria de informação em termos dos custos de monitoramento, dos custos das obrigações por parte do agente e das perdas residuais associadas às ações inapropriadas por parte do agente.

North (1991) estudou as restrições e imposições ao comportamento na forma de leis e regulações. Esse conjunto de normas inclui o comportamento moral e ético que definem as restrições, regras e regulações. Esses podem ser atrelados à propriedade e controle. $\mathrm{O}$ autor evidencia como as organizações e seus empreendedores engajados em seus propósitos determinam a mudança institucional, ou seja, os interesses dos agentes determinam as mudanças institucionais, pois eles têm um conjunto de oportunidades para explorar. Para Sour (1998), os executivos podem entrar em conflito com os proprietários, entre si próprios, ou com seus assessores.

Jensen e Meckling (1976) definiram a relação de agência e as implicações comportamentais dos contratos entre principal e agente, incluindo os problemas de agência, a assimetria da informação, os mecanismos de governança, e os incentivos para alinhamento dos interesses entre principal e agente, dentre esses o plano de remuneração. Desta forma, os diversos entraves na relação entre principal e agente, refletidos nos custos de agência, possuem um mecanismo de vinculação entre as partes, que se propõe a contribuir para minimizar os problemas de agência.

\subsubsection{Mecanismos de Vinculação}

Um desafio enfrentado pela relação de agência é como motivar os participantes das organizações, para que sejam tão produtivos como seriam se fossem os proprietários. A separação entre produtividade e 
recompensa, recomendada pela teoria econômica, é difícil de executar na prática, pois a mensuração da contribuição marginal individual, aliada ao tamanho da empresa, dificulta esta mensuração. Este problema acompanha a maioria das empresas que utilizam o desempenho atrelado à remuneração (PRATT; ZECKHAUSER, 1985).

Pratt e Zeckhauser (1985) descrevem que a corporação e a economia encontraram formas para responder a questão da separação de recompensas e produtividade. Parte da solução é o monitoramento por parte dos superiores. Os diferenciais de recompensas podem ser insuficientes, mas períodos de recompensas especiais podem ser empregados. Promoções, por exemplo, oferecem ao indivíduo salários futuros mais elevados para um futuro indefinido.

De modo geral, proprietários e agentes resolvem os problemas de agência por meio de monitoramento e vínculos. Monitorar envolve observar o comportamento e/ou desempenho dos agentes. Já a vinculação refere-se a acordos que ora penalizam os agentes ao agirem de maneira que violem os interesses dos proprietários, ora os gratificam por alcançar as metas dos proprietários. Os contratos entre agentes e proprietários especificam os acordos de monitoramento e vinculação. Assim, os contratos passam a ser centrais na teoria da agência (JENSEN; MECKLING, 1976).

Os proprietários podem utilizar mecanismos de vinculação (comprometimento), para se reassegurarem, fidelizando o agente no alcance dos objetivos traçados pelos primeiros. Esses mecanismos adotam a forma de incentivos, que os agentes criam para si. Talvez a maneira mais comum de incentivar o comprometimento esteja relacionada com o pacote de remuneração dos agentes. Se, em sua maior parte, a remuneração de um agente depende da consistência de seu comportamento e de seu desempenho com relação aos interesses do proprietário, então, considerando que os agentes valorizam recompensas financeiras, eles irão comportar-se de modo consistente com aqueles interesses. Em outras palavras, a boa vontade de um agente para aceitar essa forma de remuneração pode ser entendida como um vínculo, que garante ao principal que seus interesses serão considerados quando decisões forem tomadas (BARNEY; HESTERLY, 2004).

Para White (1985), a relação de agência está fortemente vinculada ao plano de compensação como controle em pelo menos três maneiras diferentes. A primeira é a relação causal: a compensação ajuda a definir a relação de agência, muito mais do que o inverso. A segunda, o papel convencional da compensação motivacional, dando incentivos ao agente para agir de acordo com os interesses do principal, 
considerada menos importante do que seu papel na informação e na responsabilidade como ela é e como se altera nas ações do agente. Por fim, os esquemas de compensação, são modos de estruturar a natureza evasiva e as alterações na situação da agência.

Williamson (1985) descreve que a ausência de controle contínuo, por parte do principal, permite a aqueles que receberam poder de decisão exercerem discrição de suas ações. Se o controle de propriedade é reafirmado quando o desempenho se aproxima ou cai abaixo de limiares pré-determinados, é necessário ter autonomia para intervir. A remuneração dos administradores assalariados é aparentemente desconectada do desempenho, pois os salários são ajustados em intervalos previstos pelo contrato de renovação e promoções são feitas relativas ao desempenho passado ou prometido.

Conforme Pratt e Zeckhauser (1985), o alinhamento dos objetivos é benéfico para o desempenho da relação de agência. Ambos, agente e principal, têm um incentivo para buscar um bom acordo. Assim, principal e agente devem reconhecer os méritos da elaboração de um pacote de remuneração que detém tanto demissões precipitadas como saídas indesejadas. Armstrong (1991) aborda as contradições envolvidas nas tentativas de conseguir o controle através das relações de agência no âmbito da ordem social capitalista, no sentido de repensar a teoria da agência para este fim, discutindo a propriedade e controle em termos dos sistemas de acompanhamento e incentivos.

$\mathrm{Na}$ Figura 4 evidenciam-se os autores e suas principais contribuições para a teoria da agência.

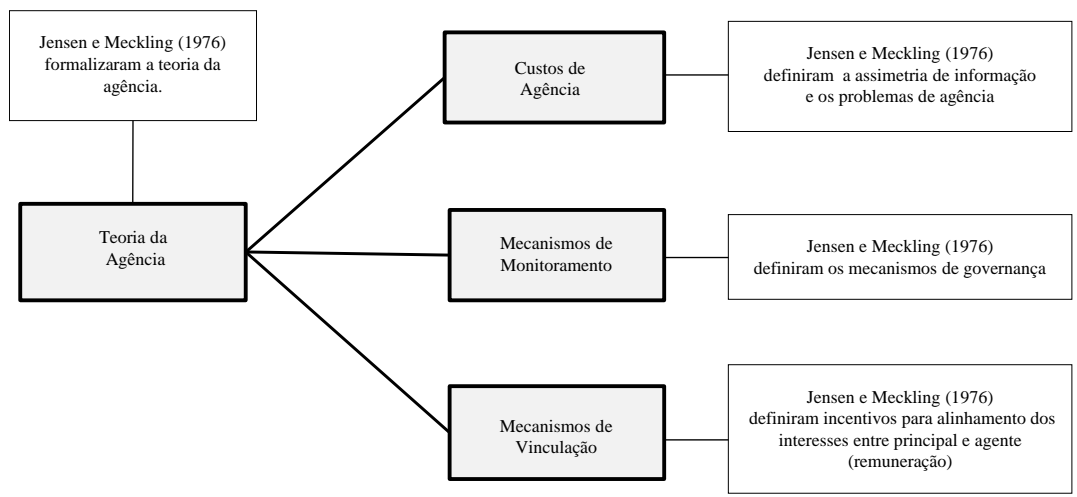

Figura 4 - Síntese da trajetória epistemológica da teoria da agência Fonte: Elaboração própria. 
Na Figura 4 nota-se que Jensen e Meckling (1976) são os autores responsáveis por várias questões conceituais da teoria da agência, tais como: assimetria da informação e problemas de agência, mecanismos de governança e incentivos para alinhamento dos interesses entre principal e agente. Embora outros autores, como Berle e Means (1932), tenham discutido temas relativos à separação e controle de propriedade anteriormente, com enfoque nos conflitos de interesse em propriedade pulverizada, a teoria da agência foi formalizada e difundida por Jensen e Meckling (1976).

Em síntese, os alicerces da teoria da agência que foram definidos para o contexto da relação de agência por Jensen e Meckling (1976) são: a) os custos de agência que se originam do conflito de interesses entre principal e agente; b) os mecanismos de monitoração que buscam mitigar os problemas de oportunismo e assimetria informacional; e c) os mecanismos de vinculação que buscam o alinhamento de interesses.

A seguir, no âmbito dos mecanismos de vinculação apresenta-se o aporte teórico da remuneração dos executivos e após do gerenciamento de resultados.

\subsubsection{Remuneração de Executivos}

Por meio dos mecanismos de vinculação, expostos por Jensen e Meckling (1976), os planos de remuneração do agente estão inclusos nas relações contratuais da teoria da agência. A literatura estrangeira denomina-os de plano de compensação ou pacote de remuneração do CEO, o que neste trabalho é entendido como sinônimo de política de remuneração de executivos.

O ano de 1979 foi um ano de destaque na literatura sobre a abordagem da informação imperfeita, os incentivos contratuais e a partilha de riscos. Conforme Holmström (1979), o papel da informação imperfeita, ou assimetria de informação, na relação entre principal e agente traduz-se no risco moral, que se origina da ação oculta, condição necessária e suficiente para embasar as negociações dos contratos baseados em remuneração. $\mathrm{O}$ autor aduz que é preciso investir recursos em acompanhamento das ações do agente e utilizar essas informações no contrato.

A partilha de riscos e incentivos e as relações entre principal e agente foram estudas por Shavell (1979), que discutiu itens que a remuneração deve envolver, como a questão da responsabilidade, da autonomia, do risco moral, da segurança, do tempo gasto na execução 
das tarefas e da expectativa de maximização dos ganhos dos acionistas. O risco moral, considerado um problema de incentivo, levou Harris e Raviv (1979) a pesquisar as relações contratuais, em situações em que estão envolvidos custos ou benefícios para o tomador de decisão. Os benefícios estão ligados à remuneração dos mesmos.

De acordo com Fama (1980), o mercado de trabalho dos agentes associa o sucesso e a falha dos gerentes com informações a respeito do talento dos mesmos, sendo que o bom desempenho das firmas pode agregar valor aos seus serviços. Mesmo que as firmas não unam explicitamente desempenho e recompensa, as forças de mercado podem trabalhar para reduzir os problemas de agência. $\mathrm{O}$ autor destaca que outras recompensas, além de compensação financeira, servem para alcançar o bem-estar dos proprietários e dos agentes. Os gestores podem receber promoções ou outras formas de reconhecimento que aumentem suas reputações e a possibilidade de um futuro aumento de salário.

A remuneração de gestores baseada em desempenho pode ser um veículo para definir o que é que eles irão fazer. A compensação flexível pode tornar-se um indicador preciso de seu desempenho na medida em que a agência a introduziu formalmente na organização. Mas se os esquemas de bônus ou forma de compensação de incentivos são mecânicos, transmitindo pouco sobre o tipo de desempenho esperado, o regime não sinaliza boas relações de agência. Recompensas monetárias e não monetárias projetadas para os gestores podem refletir-se em um maior contingente de empresas numa atmosfera de agência com um design mais adequado do que em empresas que oferecem apenas salário (WHITE, 1985).

Para Eisenhardt (1985), a concepção de planos de remuneração e recompensa, sistemas de avaliação de desempenho e sistemas de controle devem levar em consideração a incerteza dos resultados, o risco do negócio e o custo de controlar o comportamento do agente ou o custo de controlar os resultados.

Parte considerável da teoria da agência examina os incentivos que as firmas usam para induzir os agentes a trabalharem segundo os interesses dos proprietários. Do ponto de vista ideal, os proprietários prefeririam um plano de incentivo que penalizasse os agentes por omissão, ou seja, ociosidade no trabalho e por oportunismo. Entretanto, isso exporia os agentes a riscos que eles considerariam inaceitavelmente altos. Frequentemente esses riscos estão atrelados a condições que vão além do controle dos agentes. Caso os proprietários prefiram planos que enfatizem incentivos, eles precisam criar sistemas de remuneração que equilibrem remuneração fixa e variável (WINSHIP; ROSEN, 1988). 
Na Figura 5 demonstram-se os autores seminais e suas principais contribuições para a remuneração de executivos.

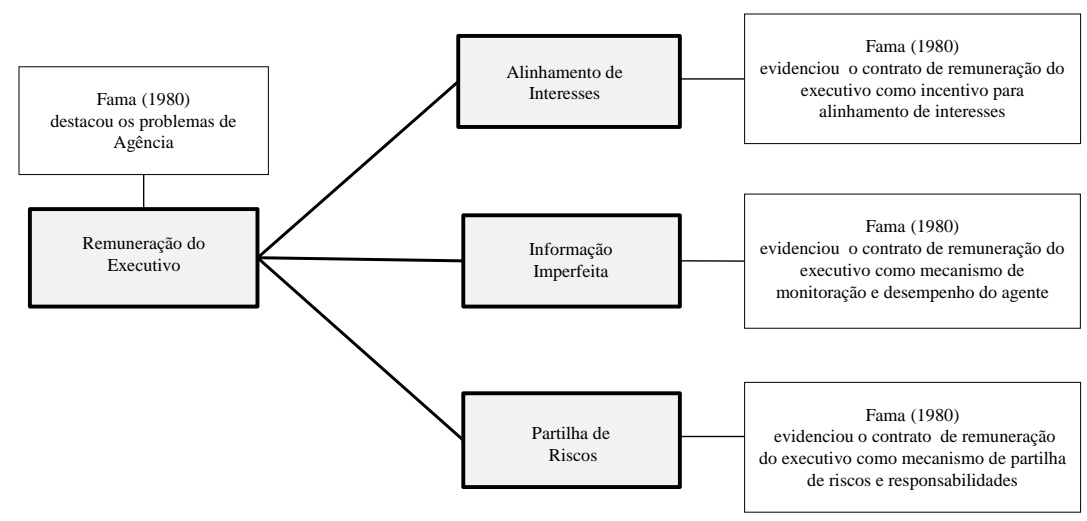

\section{Figura 5 - Síntese da trajetória epistemológica da remuneração de executivos}

Fonte: Elaboração própria.

Na Figura 5, nota-se que Fama (1980) é o autor responsável por várias questões que envolvem a remuneração do executivo. $\mathrm{O}$ autor inicia seu trabalho tratando dos problemas de agência e da teoria da firma, com foco nas relações contratuais. Nessas, o autor se focaliza no plano de remuneração do agente/executivo, apresenta vários contextos abrangidos pelo contrato, que pode ser visto como um mecanismo de alinhamento de interesses entre principal e agente, que envolve a partilha de riscos e responsabilidades, e, também, como mecanismo de monitoração e desempenho do agente.

Existem diversos mecanismos pelos quais a política de remuneração pode oferecer um valor maior de incentivos, incluindo bônus e revisões salariais baseadas em desempenho, opções de ações, e decisões de demissão baseada em desempenho (JENSEN; MURPHY, 1990). Shleifer e Vishny (1997) apresentam os planos de incentivos, como uma ferramenta para redução dos conflitos. Esses planos de incentivos levam ao planejamento da remuneração do agente, e é uma das ramificações estudadas no contexto do gerenciamento de resultados. 


\subsubsection{Gerenciamento de Resultados}

De acordo com Fama (1980), os agentes começam a se dar conta que a sua remuneração no mercado passa a ser valorizada pelo desempenho da empresa, e com isso, a relação entre a remuneração do agente e o desempenho da empresa passa a ser vista por várias óticas, pois se o desempenho da empresa for bom, a sua remuneração será valorizada.

Pela ótica da separação e controle da propriedade, Fama e Jensen (1983) analisaram a estrutura do contrato entre principal e agente com foco no processo decisório e na partilha de riscos. Conforme os autores, os contratos podem ser formalizados ou não e especificam os direitos de cada agente na organização, os critérios de desempenho sobre os quais são avaliados e os meios como são remunerados.

De acordo com Healy (1983), estudos para analisar as decisões de contabilidade gerencial postulam que executivos recompensados por remuneração baseada em bônus selecionam procedimentos contábeis que aumentam suas remunerações. Healy (1983) evidenciou também que as políticas de gestão cumulativas dos executivos são relacionadas com a divulgação dos resultados contábeis e os respectivos planos de remuneração. Ainda, que as alterações nos procedimentos contábeis pelos gestores são associadas à adoção ou alteração de seu plano de remuneração.

O gerenciamento de resultados teve seus estudos iniciados por Healy $(1983 ; 1985)$, que analisou a relação entre a remuneração de executivos e o gerenciamento de resultados; DeAngelo (1986), que estudou as decisões contábeis dos gestores; Schipper (1989), que buscou prover um quadro conceitual sobre as implicações no design das escolhas da pesquisa em gerenciamento de resultados; e Jones (1991), que investigou se as empresas se beneficiavam com a tentativa de reduzir a remuneração por meio de gerenciamento de resultados em época de investigações sobre atividades de importações. À exceção de Shipper (1989), os demais autores criaram modelos para detecção e mensuração de gerenciamento de resultados que, posteriormente, foram aperfeiçoados.

A partir dos critérios de avaliação e formas de remuneração do agente previstas no contrato, este passa a exercer um comportamento oportunístico, que, conforme Williamson (1985), consiste em uma prédisposição do agente que é imperfeito. Este comportamento oportunístico do agente pode resultar em escolhas que busquem melhorar o seu plano de remuneração. 
Um dos incentivos para a prática de gerenciamento de resultados advém do contrato entre principal e agente, pelo fato do agente possuir informações privilegiadas, se comparado aos stakeholders, em razão dos conflitos de interesses. Esses, conforme Williamson (1985), são existentes em todas as atividades de cooperação entre indivíduos.

Schipper (1989) delineia o contexto no qual se estabelecem os incentivos para a prática do gerenciamento de resultados, e defende que há práticas oportunísticas envolvendo os contratos que são prédeterminados. Expõe que a pressão econômica e institucional ao longo do tempo pode trazer a necessidade de alterações nos referidos contratos. Ressalta também que em ambiente de informação e comunicação completa, questões de gerenciamento de resultados não surgiriam.

No âmbito do desempenho da empresa, que influencia a remuneração do executivo, estão as informações contábeis. Para Healy e Wahlen (1999), as informações contábeis são utilizadas para ajudar a monitorar e regular os contratos entre a empresa e os seus stakeholders. Por sua vez, os planos de remuneração de gestores são utilizados para alinhar os interesses entre agente e principal.

$\mathrm{O}$ gerenciamento de resultados ocorre quando os gestores usam julgamento em relatórios financeiros e na estruturação de operações para modificar os relatórios financeiros, quando querem enganar alguns stakeholders sobre o desempenho econômico da empresa, ou ainda, para influenciar resultados contratuais que dependem dos números contábeis reportados (HEALY; WAHLEN, 1999).

De acordo com o exposto, os critérios de avaliação e desempenho definidos no plano de remuneração motivam o agente a exercer o oportunismo gerencial, tendo em vista os benefícios contidos no seu plano de remuneração em relação ao desempenho da empresa. Assim, o desempenho da empresa passa a ser objeto de gerenciamento de resultados. Segundo Lambert (2001), o gerenciamento de resultados é visto como uma atividade amplamente praticada pelos agentes.

$\mathrm{Na}$ Figura 6 demonstram-se os autores e suas principais contribuições para o gerenciamento de resultados atrelado ao plano de remuneração de executivos. 


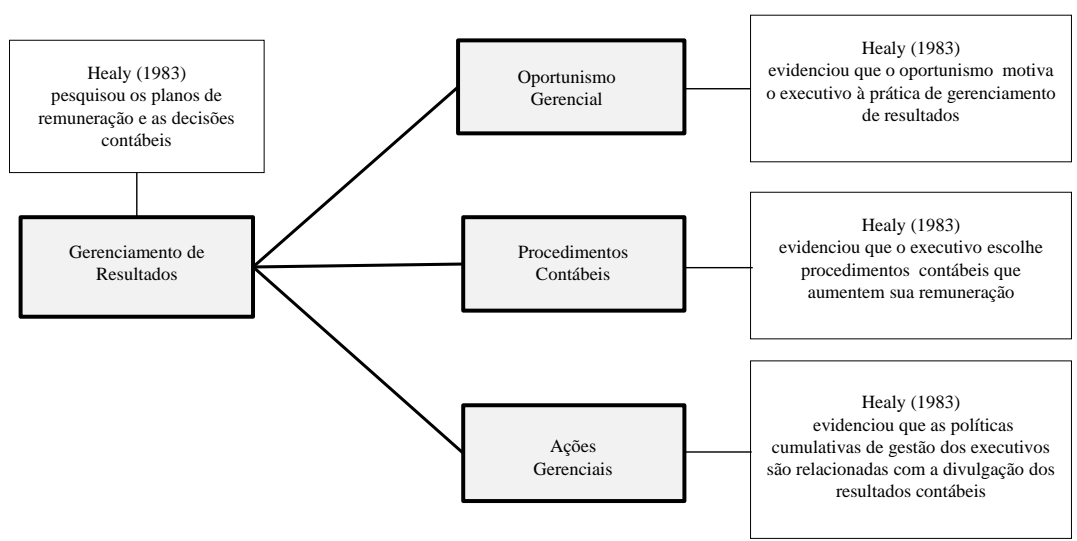

Figura 6 - Síntese da trajetória epistemológica do gerenc. de resultados

Fonte: Elaboração própria.

Na Figura 6, observa-se o gerenciamento de resultados atrelado:

a) ao oportunismo gerencial implícito nas metas de avaliação de desempenho, definidas no plano de remuneração;

b) às escolhas de procedimentos contábeis e as ações organizacionais que modificam os resultados contábeis;

c) à utilização de tais meios para maximizar o plano de remuneração. $\mathrm{O}$ intento foi demonstrar que a relação de agência prescinde do agente/executivo para efetivar a gestão nas organizações, que é envolvido pelo oportunismo para fazer suas escolhas pelas ações que cumpram as metas organizacionais e, ao mesmo tempo, atendam aos seus interesses.

Neste cenário, emerge o gerenciamento de resultados, que se constitui, por meio das escolhas contábeis e das decisões organizacionais, a ferramenta que proporciona o alcance de tais metas.

Depreende-se da epistemologia da teoria dos contratos e da teoria da agência, a origem do nexo contratual da firma, da relação de agência, da remuneração de executivos como mecanismo de vinculação entre os atores organizacionais e do gerenciamento de resultados como decorrência das ações comportamentais oportunísticas do agente. A partir do exposto, encaminha-se a revisão da literatura contemporânea sobre a remuneração de executivos e o gerenciamento de resultados, focos centrais desta pesquisa. 


\subsection{REVISÃO DE LITERATURA}

A revisão de literatura compreende a teoria da agência, a remuneração de executivos e o gerenciamento de resultados. O primeiro tema procura demonstrar que a assimetria da informação pode ser responsável tanto pela determinação do plano de remuneração do agente, quanto pelas ações praticadas por este, que por meio de escolhas contábeis, realiza o gerenciamento de resultados.

\subsubsection{Abordagem da Teoria da Agência}

Sempre que um indivíduo depende da ação de outro, surge uma relação de agência. $\mathrm{O}$ indivíduo que toma a ação é chamado de agente e a parte representada é chamada de principal. O executivo corporativo é o principal, seus subordinados os agentes. $\mathrm{O}$ executivo corporativo, por sua vez, é um agente para os acionistas. Esta relação é difundida no mundo dos negócios (PRATT; ZECKHAUSER, 1985).

Para Lambert (2001), nos modelos mais simples de agência, a organização está reduzida a duas pessoas: o principal e o agente. Os papéis do principal consistem em financiar o capital, assumir riscos, construir incentivos; enquanto que os papéis do agente compreendem tomar decisões em nome do principal e também assumir riscos. $\mathrm{Na}$ Figura 7 demonstra-se um modelo básico de agência.

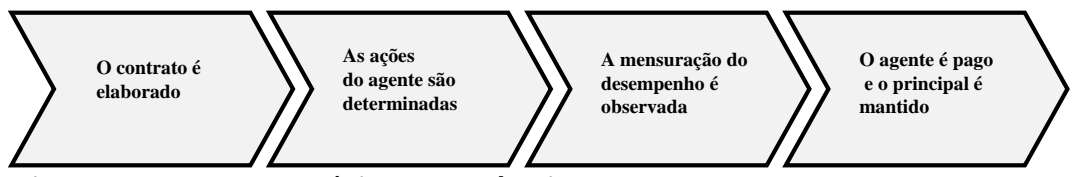

Figura 7 - Modelo básico de agência

Fonte: Adaptado de Lambert (2001, p. 6).

Observa-se na Figura 7 um modelo básico de agência, ou seja, que prevê um principal e um agente, a sequência de eventos que ocorre cronologicamente na relação contratual. Após o acordo contratual estar firmado e as ações do agente estarem selecionadas, o principal seleciona um sistema de avaliação de desempenho, que especifica indicadores que estarão atrelados à remuneração do agente, ao final o agente é remunerado e o principal mantido.

De acordo com Lambert (2001), um modelo mais complexo incluiria múltiplos agentes e múltiplos principais. Alguns agentes podem ser tanto principal como agente, dependendo da estrutura hierárquica da 
empresa. Por exemplo, um gerente de nível médio pode ser o agente dos gestores acima dele e o principal para os funcionários abaixo dele.

A teoria da agência fornece uma premissa teórica importante para a compreensão do design e dos processos organizacionais, a partir de uma perspectiva agente-principal. Em geral, uma relação de agência surge quando uma parte, o principal, contrata outra, o agente, para executar uma tarefa. Na maioria dos casos, isso implica que o agente tome decisões em nome do principal (SUBRAMANIAM, 2006).

Segundo Subramaniam (2006), a teoria da agência fornece uma perspectiva adicional de como duas ou mais partes com objetivos e divisões de trabalho diferentes podem se comportar. Gestores não são mais considerados reatores passivos de sistemas de informação, pois eles irão se comportar por interesse próprio. Para o autor, dado o relevante papel que a informação contábil desempenha nas decisões organizacionais, a utilização do quadro conceitual da teoria da agência, para explicar e prever o comportamento gerencial e organizacional tem ganhado interesse pelos pesquisadores da contabilidade.

Geralmente é o agente que possui a vantagem informacional sobre o principal. Essa vantagem é adquirida pelo agente após a contratação e durante seu envolvimento nas operações do dia-a-dia do negócio (SUBRAMANIAM, 2006). A assimetria de informação, conforme o autor, pode levar a dois tipos específicos de problemas de agência: o risco moral e a seleção adversa.

O risco moral, para Subramaniam (2006), se relaciona à capacidade limitada do principal em observar o desempenho do agente diretamente. Desta forma, o principal só pode avaliar o desempenho deste com base no resultado. Nesse caso, o agente pode se furtar de realizar plenamente os seus deveres acordados no contrato de agência ou se exceder em suas ações organizacionais, pois o principal não pode observar de forma completa as suas ações.

A seleção adversa, segundo Subramaniam (2006), surge mesmo quando o principal é capaz de observar o comportamento do agente, mas é incapaz de determinar se o esforço dispendido por este é o comportamento mais adequado.

A assimetria da informação entre principal e agente contém os problemas de agência, de risco moral e de seleção adversa, inerente a toda relação em que uma parte contratante tem o poder decisorial, mas é subordinado ao outro. O agente possui a informação completa sobre os eventos econômicos que abrangem a organização, passando ao principal apenas parte desta informação, porque lhe é exigido ou porque lhe convém informar determinada parte. Neste contexto entra a 
remuneração de executivos, que, por vincular a relação entre o principal e o agente, possibilita alinhar interesses reduzindo a assimetria.

\subsubsection{Elementos da Remuneração de Executivos}

A literatura que trata da remuneração do executivo tem evoluído de forma interdisciplinar, abrangendo a contabilidade, a economia, as finanças, as relações industriais, $\mathrm{o}$ direito, $\mathrm{o}$ comportamento organizacional e a estratégia. A maioria das pesquisas tem utilizado testes de aplicação da teoria da agência (MURPHY, 1999).

Conforme Baber, Janakiraman e Kang (1996), os determinantes da remuneração do executivo variam diretamente de acordo com o desempenho da empresa. Desde que as ações do agente sejam inobserváveis pelo principal, os indicadores de desempenho se presumem estarem correlacionados com as ações do agente.

A responsabilidade de supervisionar a concepção e implementação do plano anual de incentivos do executivo é atribuída ao comitê de remuneração. Este comitê geralmente é composto por membros de fora do conselho de administração, isto é, dentre os demais empregados (DECHOW; HUSAN; SLOAN, 1994). De acordo com Murphy (1999), os executivos máximos negociam formalmente seus contratos de trabalho, que tem duração média de cinco anos, preveem um salário de base mínimo, pagamentos de bônus-alvo (com ou sem garantias), e arranjos indenizatórios em caso de separação ou mudança no controle societário.

Conforme Murphy (1999), parte da controvérsia sobre a remuneração do CEO reflete uma percepção de que CEOs efetivamente definem seus níveis próprios de remuneração. As decisões finais sobre a remuneração dos executivos são feitas por membros externos do conselho de diretores, que estão conscientes dos conflitos de interesses entre administradores e acionistas sobre o nível de remuneração. Não há dúvida, porém, que os CEOs e outros gestores da diretoria, exerçam, pelo menos, alguma influência no nível e estrutura de seu pagamento.

\subsubsection{Componentes de Remuneração}

Embora haja heterogeneidade nas práticas de pagamento entre as empresas e indústrias, os planos de remuneração do executivo devem conter quatro componentes básicos: salário-base, bônus anual vinculado ao desempenho contábil ou a outro indicador acordado entre as partes, opções de ações e planos de incentivos de longo prazo (incluindo planos 
restritos de ações e planos de desempenho baseados na contabilidade de vários exercícios). Os executivos também participam de amplo plano de benefícios de empregados e recebem benefícios especiais, incluindo seguro de vida e planos de aposentadoria complementar (MURPHY, 1999).

$\mathrm{Na}$ sequência, expõem-se conceitualmente estas verbas remuneratórias, ou seja, os componentes de remuneração descritos, essencialmente, por Murphy (1999).

a) Salário

O salário-base para os CEOs, segundo Murphy (1999), são normalmente determinados por meios competitivos, usando benchmarking, baseados principalmente em pesquisas das remunerações pagas pelas empresas em geral, e complementados por análises detalhadas de pares selecionados de empresas de segmentos específicos ou de mercado.

Smith Jr. e Watts (1992) esclarecem que o salário pode ser periodicamente renegociado, formal ou informalmente, por exemplo, com base no desempenho anterior. Nos casos em que o acordo é informal, caso uma das partes não cumpra o acordo, a outra parte desmotiva-se para dar continuidade ao esperado por seu desempenho.

De acordo com Murphy (1999), os executivos dedicam atenção substancial para o processo de determinação de salário, pois são peçaschave nos contratos de trabalho, normalmente garantem o aumento mínimo em salários base para os cinco anos subsequentes. Uma vez que os salários de base representam o componente fixo da remuneração, os executivos avessos ao risco preferem um aumento no salário base a um aumento na meta para obtenção de bônus ou de remuneração variável. A maioria dos componentes da remuneração é medida em relação aos níveis de salário base.

b) Bônus Anual

As empresas com fins lucrativos geralmente oferecem um plano de bônus anual para os executivos de nível máximo, pagos anualmente com base no desempenho de um único ano (MURPHY, 1999). De acordo com o autor, apesar da grande heterogeneidade entre as empresas, os planos de bônus de executivos podem ser classificados em termos de três componentes básicos: medidas de desempenho, desempenho padrão e estrutura da relação pay-performance. 
Murphy (1999) descreve que na maioria das vezes, as medidas de desempenho são múltiplas e aditivas. Em alguns casos, as medidas são multiplicativas, em que o bônus pago em uma medida de desempenho pode ser aumentado ou diminuído dependendo da realização de outra medida. Em outros casos, os pagamentos de bônus são determinados por uma matriz de medidas de desempenho. Além de usar medidas ou indicadores financeiros e não financeiros, a maioria das empresas utiliza também indicadores contábeis.

Quanto ao desempenho padrão, cada empresa tem um processo distinto para determinar os padrões alvo para cada medida de desempenho, normalmente baseados na contabilidade, utilizando um orçamento, ou outro artefato gerencial. No caso da utilização do plano de negócios da empresa ou metas orçamentárias, estas determinarão qual o desempenho padrão a ser alcançado (MURPHY, 1999).

Para Murphy (1999), a estrutura de pay-performance (remuneração atrelada ao desempenho) é determinada de diferentes formas pelas empresas, podendo ser por faixas. Por exemplo, o método mais comum é 80/120, ou seja, nenhum bônus é pago se o desempenho não alcançar pelo menos $80 \%$ da meta. Já no caso do desempenho alcançar $120 \%$ da meta o bônus é limitado.

Dalmacio, Rezende e Slomski (2009) listam medidas de performance utilizadas nos contratos de remuneração pelos gestores brasileiros, dentre os indicadores contábeis utilizados, destacam-se a margem bruta, a margem EBIT, a margem operacional, a margem líquida, a margem EBITDA, a rentabilidade do ativo e a rentabilidade do patrimônio líquido.

O uso do plano de bônus cresceu nas empresas, conforme Sloan (1993). Ele era utilizado em 1960 por 35\% das empresas industriais estadunidenses, já em 1988 era utilizado por 99\% das mesmas (SLOAN, 1993). Murphy (1999) acrescenta que praticamente todos os planos de bônus anual fornecem incentivos para aumentar os lucros da empresa.

c) Opções de Ações

Opção é um direito de comprar uma quantidade de ações numa data, ou após uma data, no futuro, data de exercício da opção, a um preço fixado na data em que a opção é oferecida (ANTHONY; GOVINDARAJAN, 2002). Para Murphy (1999), as opções de ações possuem a forma de contratos, que dão ao destinatário direito de comprar uma parte das ações por um preço de exercício pré-estabelecido por um período pré-especificado. Geralmente, tornam-se investimentos 
ao longo do tempo: por exemplo, $25 \%$ das opções de ações podem se tornar exercíveis em cada um dos quatro anos seguintes a subvenção.

Segundo Murphy (1999), as opções para executivos não são negociáveis, e normalmente são perdidas caso o executivo deixe a empresa antes da aquisição. Constitui-se em um arranjo indenizatório comumente negociado pelas empresas, especialmente após uma mudança de controle societário. A remuneração em forma de opções de ações incentiva o executivo a trabalhar de forma a valorizar o preço das ações, e não o retorno ao acionista, pois assim estará aumentando a sua riqueza e não os dividendos que serão percebidos pelo principal.

Quanto às questões fiscais e contábeis, as opções de ações parecem um caminho natural para vincular a remuneração de executivos ao desempenho do preço das ações da empresa. No entanto, além das implicações de incentivo óbvias, a popularidade deste modo de remunerar se refletem, em grande parte, no tratamento fiscal e contábil favorável, em particular as opções de ações oferecem uma maneira atrativa de adiar o lucro tributável, e são em grande parte, invisíveis nas demonstrações contábeis da empresa (MURPHY, 1999).

Nagar, Nanda e Wysicki (2003) argumentam que os incentivos baseados em opções de ações, sob a forma de remuneração baseada em ações e participação acionária, mitigam o problema de divulgação de agência, pois os gestores têm acesso a informações que os investidores exigem, mas são relutantes em divulgá-las publicamente, a menos que tenham incentivos adequados.

d) Outras formas de remuneração

Murphy (1999) enumera ainda os planos de incentivos de longo prazo, que incluem as ações restritas e os planos de benefícios de empregados como outras formas de remuneração.

Além dos planos de bônus com base no desempenho anual, várias empresas oferecem planos de incentivos de longo prazo, tipicamente baseados na média de três ou cinco anos de desempenho cumulativo. Por exemplo, ações restritas, que são semelhantes à remuneração em ações, podem ser concedidas ao executivo, mas que este só pode adquirir sob determinadas condições, geralmente relacionadas à longevidade na empresa.

Os executivos também participam de amplo plano de benefícios de empregados, tais como: seguro de vida, plano de aposentadoria complementar e benefícios das mais variadas formas, que incluem tempo de serviço ou ainda atrelados ao desempenho da empresa. 
Os componentes de remuneração conceituados (salários, bônus, ações e outras remunerações) podem ser combinados de diferentes formas pelas partes contratantes. Estas se constituem na política de remuneração, que é definida de forma particular em cada empresa.

\subsubsection{Políticas de Remuneração}

A política de remuneração é entendida de forma diversa na literatura. Smith Jr. e Watts (1992) utilizaram apenas o salário do CEO como sinônimo de política de remuneração. Baber, Kang e Kumar (1998) consideraram salário, bônus e mais a remuneração baseada em ações. Já Murphy (1999) incluiu a remuneração fixa, variável, além dos benefícios pós-emprego. A equação 1, descrita a seguir, foi elaborada a partir de Murphy (1999):

(Equação 1)

$$
P R E_{i t}=\text { Salário }_{i t}+\text { Bônus }_{i t}+\text { Ações }_{i t}+\text { Outras }_{i t}
$$

Onde:

$P R E_{i t}=$ política de remuneração do executivo da empresa i no período t;

Salário $_{i t}=$ remuneração fixa que serve de base de cálculo para outros benefícios da empresa i no período t;

$B$ ônus $s_{i t}=$ plano de bônus anual e/ou participação nos resultados da empresa i no período t;

$A c ̧ \tilde{e} e S_{i t}=$ remuneração baseada em ações da empresa i no período t;

Outras $_{i t}=$ outras formas de remuneração, incluindo benefícios pós-emprego da empresa i no período t.

O termo remuneração em dinheiro é utilizado para designar a remuneração equivalente ao salário mais bônus anual e se constitui num percentual significativo da remuneração total (LAMBERT; LARCKER, 1987).

Existem diversos mecanismos pelos quais a política de remuneração pode oferecer um valor maior de incentivos, incluindo bônus e revisões salariais baseados em desempenho, opções de ações, e decisões de demissão baseadas em desempenho. CEOs de grandes empresas tendem a possuir menos incentivos de remunerações baseados 
em ações do que CEOs de empresas menores (JENSEN; MURPHY, 1990).

A remuneração dos executivos máximos é explicitamente ligada aos lucros anuais, por meio dos planos de bônus e dos planos de desempenho de longo prazo. Os lucros são predominantes nos contratos de remuneração das organizações como indicadores de desempenho (SLOAN, 1993). A utilização generalizada de incentivos baseados nos lucros gerou preocupações de que os executivos pudessem escolher decisões reais e procedimentos contábeis para maximizar sua remuneração, independentemente do impacto no bem-estar econômico da empresa (DECHOW; HUSON; SLOAN, 1994).

A partir da definição e efetivação da política de remuneração pela empresa, origina-se a obrigação acessória, para atendimento aos órgãos reguladores das companhias abertas, de evidenciação de tal política. A seguir expõe-se a regulamentação da evidenciação desta para os Estados Unidos, Inglaterra e Brasil, que são objetos de estudo desta pesquisa.

\subsubsection{Regulamentação da Evidenciação da Remuneração}

Normas específicas de divulgação sobre a remuneração do executivo nos Estados Unidos da América vigoram desde 1938, por meio do Ato Executivo $\mathrm{n}^{\circ}$ 34-1823, de 11 de agosto de 1938, da United States Securities and Exchange Commission (SEC). Atualizações desta regulamentação ocorreram em 1942, 1952, 1978 e a versão mais recente é de 1983. Esta última considera a evidenciação mais completa da política de remuneração do executivo, pois inclui a remuneração em dinheiro, e, é oriunda do Ato Executivo no 33-6486, de 23 de setembro de 1983. A evidenciação é compulsória para empresas com ações negociadas em bolsas de valores.

Na Inglaterra, a evidenciação da remuneração do executivo se iniciou pela produção do Greenbury Report, em 15 de julho de 1995, pelo Comitê da Confederação de Negócios e Indústrias sobre Governança Corporativa do Reino Unido. Esta regulamentação recomenda a estruturação de um Comitê de Remuneração e do Código de Melhores Práticas de Evidenciação da Remuneração dos Administradores nas empresas com ações negociadas na London Stock Exchange (LSE). Inicialmente, a evidenciação poderia ser realizada como parte da Declaração Anual de Conformidade aos Acionistas, em uma seção separada ou anexada as Demonstrações Financeiras das Empresas. 
Ferrarini e Moloney (2010), ao relatarem em sua pesquisa as práticas de remuneração de executivos da União Europeia, destacam que no Reino Unido a divulgação dos planos de remuneração de todos os executivos é efetuada de forma detalhada e individualizada (incluindo salário, bônus, opções de ações, e regimes de incentivos de longo prazo), bem como informações sobre a política de remuneração, nos relatórios de contas anuais e essa evidenciação proporciona comparações com outros países.

No Brasil, a Instrução Normativa (IN) no 480 da Comissão de Valores Mobiliários (CVM), de 7 de dezembro de 2009, determinou que seja evidenciada a política de remuneração dos administradores, por meio do Formulário de Referência da própria CVM, segregando a remuneração em: fixa, variável, benefícios pós-emprego, benefícios motivados pela cessação do exercício do cargo e remuneração baseada em ações. Esta IN entrou em vigor em $1^{\circ}$ de janeiro de 2010, sobre as informações relativas aos três últimos exercícios sociais e do exercício corrente, ou seja, de 2007 a 2010.

A partir da evidenciação da política de remuneração, que compreende o nível e a estrutura desta pelos diversos países, inclusive, recentemente, para o Brasil, haverá maior possibilidade de pesquisas empíricas sobre o tema.

\subsubsection{Estudos Anteriores - Remuneração de Executivos}

Os estudos anteriores referem-se à aplicação em pesquisas do aporte teórico relativo à remuneração de executivos e está dividido em estudos nacionais e internacionais.

a) Pesquisas publicadas em periódicos nacionais

Para buscar estudos anteriores realizados nacionalmente, foram selecionados os periódicos de contabilidade classificados pelo Webqualis da Coordenação de Aperfeiçoamento de Pessoal de Nível Superior (CAPES) (2012) nos estratos A2, B1 e B2, apresentados no Quadro 2. 


\begin{tabular}{|l|c|c|}
\hline \multicolumn{1}{|c|}{ Periódicos Nacionais } & Responsável & Qualis \\
\hline Brazilian Business Review - BBR & FUCAPE & A2 \\
\hline Revista de Contabilidade \& Finanças - RC\&F & USP/SP & A2 \\
\hline Contabilidade Vista \& Revista - CVR & UFMG & B1 \\
\hline Revista Brasileira de Finanças - RBF & FGV & B1 \\
\hline Revista Brasileira de Gestão de Negócios - RBGN & FECAPE & B1 \\
\hline Revista de Contabilidade e Organizações - RCO & USP/RP & B1 \\
\hline Revista Universo Contábil - RUC & FURB & B1 \\
\hline Revista de Administração e Contabilidade - BASE & UNISINOS & B2 \\
\hline Contabilidade, Gestão e Governança - CGG & UnB & B2 \\
\hline Enfoque: Reflexão Contábil & UEM & B2 \\
\hline
\end{tabular}

\section{Quadro 2 - Periódicos nacionais - remuneração de executivos}

Fonte: CAPES (2012).

A busca de artigos nos dez periódicos listados no Quadro 2 foi direcionada pela procura das palavras 'remuneração', 'CEO', e 'executivo', no título, resumo e palavras-chave. Foram desconsiderados os artigos que versam sobre remuneração dos acionistas. O período compreendido pela busca abrange desde a criação dos periódicos, ou seja, sua primeira edição, até a edição disponibilizada eletronicamente no final de março de 2012. A busca resultou em 8 artigos, listados no Quadro 3, e comentados sinteticamente a seguir.

\begin{tabular}{|l|l|}
\hline \multicolumn{1}{|c|}{ Autores (ano) } & \multicolumn{1}{|c|}{ Título } \\
\hline Nunes e Marques (2005) & $\begin{array}{l}\text { Planos de incentivos baseados em opções de } \\
\text { ações: uma exposição das distinções encontradas } \\
\text { entre as demonstrações contábeis enviadas à } \\
\text { CVM à SEC. }\end{array}$ \\
\hline Galdi e Carvalho (2006) & $\begin{array}{l}\text { Remuneração em opções de ações: o SFAS 123 } \\
\text { revisado. }\end{array}$ \\
\hline $\begin{array}{l}\text { Oliva e Albuquerque } \\
\text { (2007) }\end{array}$ & $\begin{array}{l}\text { Sistema de remuneração de executivos e } \\
\text { conselheiros como suporte à estrutura de } \\
\text { governança corporativa. }\end{array}$ \\
\hline Souza e Borba (2007) & $\begin{array}{l}\text { Governança corporativa e remuneração de } \\
\text { executivos: uma revisão de artigos publicados no } \\
\text { exterior. }\end{array}$ \\
\hline $\begin{array}{l}\text { Dalmacio, Rezende e } \\
\text { Slomski (2009) }\end{array}$ & $\begin{array}{l}\text { Análise setorial das medidas de performance } \\
\text { utilizadas nos contratos de remuneração dos } \\
\text { gestores. }\end{array}$ \\
\hline
\end{tabular}




\begin{tabular}{|l|l|}
\hline Oyadomari et al. (2009) & $\begin{array}{l}\text { Influências da Remuneração de Executivos na } \\
\text { Congruência de Metas. }\end{array}$ \\
\hline $\begin{array}{l}\text { Rodrigues e Seabra } \\
(2011)\end{array}$ & $\begin{array}{l}\text { Remuneração dos administradores dos bancos } \\
\text { portugueses do PSI20. }\end{array}$ \\
\hline $\begin{array}{l}\text { Nascimento, Franco e } \\
\text { Cherobim (2012) }\end{array}$ & $\begin{array}{l}\text { Associação entre remuneração variável e } \\
\text { indicadores financeiros: evidências do setor } \\
\text { elétrico }\end{array}$ \\
\hline
\end{tabular}

\section{Quadro 3 - Pesquisas nacionais - remuneração de executivos}

Fonte: Elaborado com base nos periódicos pesquisados.

Nunes e Marques (2005), ao estudar os planos de incentivos baseados em opções de ações nas demonstrações contábeis enviadas à CVM e à SEC, apresentam os fundamentos das opções de ações para funcionários e as normas existentes no tratamento contábil dos planos. No estudo empírico dos autores foram selecionadas 14 companhias abertas nacionais e as informações coletadas demonstraram que há diferenças entre o que é divulgado para os órgãos reguladores e o mercado de capitais brasileiro, em comparação à divulgação aos órgãos reguladores e ao mercado de capitais internacional.

Galdi e Carvalho (2006) abordaram temas relacionados à remuneração baseada em ações, concentrando-se na remuneração com opções de ações, buscando expor e analisar a estrutura conceitual do SFAS 123 revisado. Os autores apresentaram a evolução histórica da normatização do tema, discorrendo sobre os principais conceitos emanados do SFAS 123 revisado, abordando a argumentação utilizada pelo FASB para o embasamento teórico da norma.

Oliva e Albuquerque (2007), ao pesquisarem o sistema de remuneração de executivos e conselheiros como suporte à estrutura de governança corporativa, no intuito de verificar se existe alinhamento entre o sistema de remuneração de executivos e conselheiros com a estrutura de governança corporativa, por meio de pesquisa exploratória, com entrevistas junto às empresas que aderiram aos níveis diferenciados de governança corporativa da Bovespa, afirmaram que houve alinhamento entre a Estrutura de Governança Corporativa e o Sistema de Remuneração de Administradores.

Souza e Borba (2007) realizaram pesquisa bibliométrica de artigos publicados no exterior que discutem políticas de remuneração. A busca foi realizada pelos termos governance e compensation no abstract. No ano de 2005, foi encontrada a maior quantidade de artigos publicados sobre o assunto. Os cinco periódicos internacionais da área da administração que mais evidenciaram foram: Journal of Accounting 
and Economics, Journal of Accounting and Public Policy, Journal of Corporate Finance, Journal of Financial Economics Corporate Governance. O assunto mais debatido nos artigos avaliados foi a remuneração do executivo principal, e quanto aos países focados nas pesquisas, o destaque foi para o continente americano, o qual totalizou $66 \%$ da amostra de artigos empíricos.

Dalmacio, Rezende, e Slomski (2009) verificaram se existe variabilidade entre os setores, nos indicadores contábeis utilizados como medidas de performance nos contratos de remuneração variável dos gestores. Realizaram pesquisa exploratória em empresas brasileiras de 17 setores econômicos, no período de 1998 a 2005, todas com ações negociadas na BM\&FBovespa. As análises foram baseadas no paradigma Estrutura, Conduta e Desempenho. Os resultados indicaram que, somente, em alguns setores específicos, os indicadores de performance podem ser utilizados como parâmetros de remuneração dos gestores.

Oyadomari et al. (2009) estudaram as influências da remuneração de executivos na congruência de metas, buscando identificar quais são as práticas de remuneração variável adotadas pelas empresas e como as metas de remuneração estão atreladas às metas oriundas do Sistema de Controle Gerencial e, também, se há congruência entre as metas individuais e organizacionais. $\mathrm{O}$ estudo foi desenvolvido junto a 21 empresas de grande porte. Os resultados obtidos sugerem que:

a) a remuneração variável, com metas individuais, está associada ao alcance das metas organizacionais;

b) as práticas adotadas pelo mercado para a remuneração variável têm peso diferenciado em termos de influência sobre o comportamento do gestor;

c) o conflito de agência pode se apresentar se as metas individuais não foram associadas às metas globais da organização;

d) o sistema de remuneração variável tem um efeito motivador na busca por desempenho.

Rodrigues e Seabra (2011) realizaram pesquisa seguindo uma metodologia de estudo de caso, como complemento da dimensão teórica que constitui a primeira parte da pesquisa. Os autores estudaram a 
remuneração dos conselhos de administração dos bancos portugueses cotados na NYSE Euronext Lisbon (Índice PSI20). Os resultados apontaram que não existe um conjunto coerente de boas práticas, no que diz respeito à remuneração dos administradores das instituições bancárias, em Portugal.

Nascimento, Franco e Cherobim (2012) pesquisaram se existe relação entre os índices contábeis financeiros e as práticas de remuneração variável nas empresas do setor de energia elétrica do Brasil. A amostra analisada foi composta por 49 empresas listadas na BM\&FBovespa. Os índices contábeis financeiros utilizados foram: margem líquida, taxa de retorno sobre o ativo total, retorno sobre o patrimônio líquido e o lucro disponível ao acionista. Os resultados indicam que as práticas de remuneração variável não têm influência positiva nos resultados dos índices de lucratividade e rentabilidade das empresas do setor elétrico brasileiro.

b) Pesquisas publicadas em periódicos internacionais

Sobre a remuneração dos executivos a busca por pesquisas internacionais realizadas investigou os periódicos internacionais de contabilidade, disponibilizados no portal de periódicos da CAPES (2011), indexados ao Journal Citation Report (JCR), conforme se verifica no Quadro 4. Estes foram revisados pelo período de 16 anos, ou seja, entre 1995 e 2010.

\begin{tabular}{|l|}
\hline \multicolumn{1}{|c|}{ Periódicos indexados ao JCR } \\
\hline Abacus - A Journal of Accounting, Finance and Business \\
\hline Accounting, Organizations and Society \\
\hline Journal of Accounting and Economics \\
\hline Journal of Business Finance and Accounting \\
\hline The Accounting Review \\
\hline Review of Accounting Studies \\
\hline
\end{tabular}

Quadro 4 - Periódicos internacionais - remuneração de executivos Fonte: CAPES (2011).

Dentre os periódicos listados no Quadro 4 foram selecionados artigos que continham os termos CEO Compensation, ou Executive Compensation em seu título. No Quadro 5 apresentam-se os 11 trabalhos mais citados, dentre os 216 artigos localizados. 


\begin{tabular}{|c|c|}
\hline Autores (ano) & Título \\
\hline Lambert e Larcker (1987) & $\begin{array}{l}\text { An analysis of the use of accounting and } \\
\text { market measures of performance in executive } \\
\text { compensation contracts. }\end{array}$ \\
\hline Jensen e Murphy (1990) & $\begin{array}{l}\begin{array}{l}\text { Performance pay and top-management } \\
\text { incentives. }\end{array} \\
\text { incen }\end{array}$ \\
\hline Smith Jr. e Watss (1992) & $\begin{array}{l}\text { The investment opportunity set and corporate } \\
\text { financing, dividend and compensation policies. }\end{array}$ \\
\hline Gaver e Gaver (1993) & $\begin{array}{l}\text { The investment opportunity set and corporate } \\
\text { financing, dividend and compensation policies. }\end{array}$ \\
\hline Sloan (1993) & $\begin{array}{l}\text { Accounting earnings and top executive } \\
\text { compensation. }\end{array}$ \\
\hline $\begin{array}{l}\text { Dechow, Husan e Sloan } \\
\text { (1994) }\end{array}$ & $\begin{array}{l}\text { The effect of restructuring charges on } \\
\text { executives' cash compensation. }\end{array}$ \\
\hline $\begin{array}{l}\text { Baber, Janakiraman e } \\
\text { Kang (1996) }\end{array}$ & $\begin{array}{l}\text { Investment opportunities and the structure of } \\
\text { executive compensation. }\end{array}$ \\
\hline $\begin{array}{l}\text { Baber, Kang e Kumar } \\
\text { (1998) }\end{array}$ & $\begin{array}{l}\text { Accounting earnings and } \\
\text { compensation: } \\
\text { persistence. }\end{array}$ \\
\hline Gaver e Gaver (1998) & $\begin{array}{l}\text { The relation between nonrecurring accounting } \\
\text { transactions and CEO cash compensation. }\end{array}$ \\
\hline $\begin{array}{l}\text { Baber, Kang e Kumar } \\
\text { (1999) }\end{array}$ & $\begin{array}{l}\text { The explanatory power of earnings levels vs. } \\
\text { earnings changes in the context of executive } \\
\text { compensation. }\end{array}$ \\
\hline Murp & Executive compensation. \\
\hline
\end{tabular}

Quadro 5 - Pesquisas internacionais - remuneração de executivos

Fonte: Elaborado com base nos periódicos pesquisados.

A busca resultou em 11 artigos, listados no Quadro 5, que estão comentados sinteticamente a seguir.

Lambert e Larcker (1987) examinaram empiricamente se existe uma associação positiva entre a influência do retorno sobre a ação e o retorno sobre o patrimônio líquido na remuneração de executivos estadunidenses. Os resultados são consistentes com a hipótese de que as empresas colocam um peso relativamente maior no desempenho do mercado acionário, e menor sobre o desempenho contábil, nos planos de remuneração.

Jensen e Murphy (1990) descobriram em sua pesquisa que a remuneração do CEO dos Estados Unidos (incluindo salário, opções, ações e verbas rescisórias) aumenta US\$ 3.25 para cada US\$1,000 de aumento na riqueza dos acionistas. Observaram também que forças políticas afetam o nível de remuneração dos CEOs. 
Smith Jr. e Watts (1992) apresentaram evidências sobre as relações entre as opções de crescimento e as políticas de remuneração, entre regulação e alavancagem, entre dividendos e políticas de remuneração, e entre as próprias políticas de remuneração, em empresas dos Estados Unidos.

Gaver e Gaver (1993) observaram em sua pesquisa que empresas dos Estados Unidos em crescimento pagam níveis mais elevados de remuneração em dinheiro para seus executivos e têm uma maior incidência de planos de opção de ações do que as empresas que não estão em crescimento.

Sloan (1993) investigou em sua dissertação, defendida nos Estados Unidos, que o papel dos lucros contábeis nos contratos de remuneração dos executivos superiores, fornece evidências para apoiar a hipótese de que os ganhos baseados em números contábeis ajudam os executivos a se protegerem de fatores que provocam flutuações no valor de mercado das ações.

A pesquisa de Dechow, Husan e Sloan (1994) encontrou evidência empírica de que o comitê de remuneração desempenha um papel ativo, ajustando os resultados da empresa reportados, com a finalidade de determinar prêmios de incentivos anuais em empresas dos Estados Unidos.

Os resultados do estudo de Baber, Janakiraman e Kang (1996), em empresas dos Estados Unidos, demonstraram que há forte associação entre a remuneração de executivos e o desempenho da empresa com grandes oportunidades de investimento.

Baber, Kang e Kumar (1998) identificaram que a sensibilidade dos ganhos de remuneração varia diretamente com a persistência de lucros em empresas dos Estados Unidos, também que a sensibilidade é maior quando os executivos estão perto da aposentadoria.

O estudo de Gaver e Gaver (1998) revelou que a remuneração, em empresas de grande porte dos Estados Unidos, é positivamente relacionada com ganhos acima do padrão de remuneração, enquanto os resultados são positivos.

Conforme a pesquisa de Baber, Kang e Kumar (1999), com 712 executivos dos Estados Unidos, os níveis de lucros, as alterações na remuneração e a persistência de lucros precisam ser consideradas quando se investiga as relações entre lucros contábeis e remuneração de executivos.

A pesquisa de Murphy (1999) resume a pesquisa empírica e teórica sobre a remuneração dos executivos e oferece uma abrangente e contemporânea descrição das práticas de remuneração (e as tendências 
das práticas de pagamento) para os principais executivos (CEOs), de 23 países. Os tópicos discutidos incluem o nível e a estrutura salarial dos CEOs (incluindo a análise detalhada dos planos de bônus anual e opções de ações executivas, e a opção de avaliação), diferenças salariais internacionais, o processo de definição de remuneração, a relação entre os salários dos CEOs e o desempenho da empresa, a relação entre a sensibilidade e o desempenho subsequente da empresa, a avaliação de desempenho relativo, a rotatividade de executivos, e a política salarial dos CEOs.

Conforme Murphy (2001), pesquisas de incentivos tem se concentrado em medidas de desempenho, remuneração por desempenho e sensibilidade, mas tem ignorado o 'padrão de desempenho', que gera importantes incentivos como parte do plano de remuneração.

Após apresentar a revisão de literatura da remuneração dos executivos, com aporte teórico sobre o framework conceitual do tema, os componentes de remuneração, a regulamentação da evidenciação da remuneração e os estudos anteriores nacionais e internacionais, com predominância das pesquisas divulgadas nos Estados Unidos, segue-se a revisão de literatura do gerenciamento de resultados.

\subsubsection{Aspectos do Gerenciamento de Resultados}

Pesquisadores de gerenciamento de resultados, em âmbito nacional e internacional têm utilizado o conceito de Schipper (1989) e Healy e Wahlen (1999) para esclarecer o gerenciamento de resultados (earnings management). Conforme esses autores, o gerenciamento de resultados pode ser entendido como uma intervenção proposital no processo de comunicação financeira externa, com a intenção de obter algum benefício privado que pode ocorrer em qualquer etapa do processo de divulgação externa.

Dado que o gerenciamento de resultados é baseado na ótica de evidenciação das informações contábeis, Schipper (1989) cita três questões fundamentais em sua discussão conceitual sobre o tema: o objeto de gerenciamento de resultados, as condições que dão origem ao gerenciamento de resultados e o modelo de teste empírico de gerenciamento de resultados.

A primeira questão é de que o gerenciamento de resultados é realizado em decorrência temporal nos investimentos ou decisões financeiras para alterar as demonstrações reportadas ou uma parte delas. Os números contábeis resultantes podem ser suavizados no sentido de que a sua variabilidade ao longo de tempo seja reduzida. Diferentes 
formas de gerenciamento de resultados baseado em accruals não são fáceis de discernir. Segundo Schipper (1989), ante a perspectiva informacional, o gerenciamento de resultados é realizado com base em decisões gerenciais que envolvem julgamento de valor.

A segunda questão está relacionada ao comportamento humano, como a gestão oportunística; aos interesses particulares, como os incentivos contratuais que se utilizam de metas contábeis. Ambos são considerados estímulos para que o gerenciamento de resultados se realize.

A última questão é relativa aos modelos de pesquisas empíricas para detecção e mensuração do gerenciamento de resultados por meio das accruals. Schipper (1989) comentou os modelos de DeAngelo (1986) e McNichols e Wilson (1988). No entanto, têm-se vários outros modelos desenvolvidos desde então.

Conforme Healy (1983), as accruals representam a diferença entre o lucro líquido e o fluxo de caixa das operações, ou seja, entre o regime de caixa e de competência. Martinez (2001) explicita o conceito, esclarecendo que se referem a todas as contas de resultado que entraram no cômputo do lucro, mas que não representaram movimentação de disponibilidades. Também, que se dividem em discricionárias e não discricionárias. Com relação às accruals, a Figura 8, desenvolvida inicialmente por Martinez (2001), se torna elucidativa.

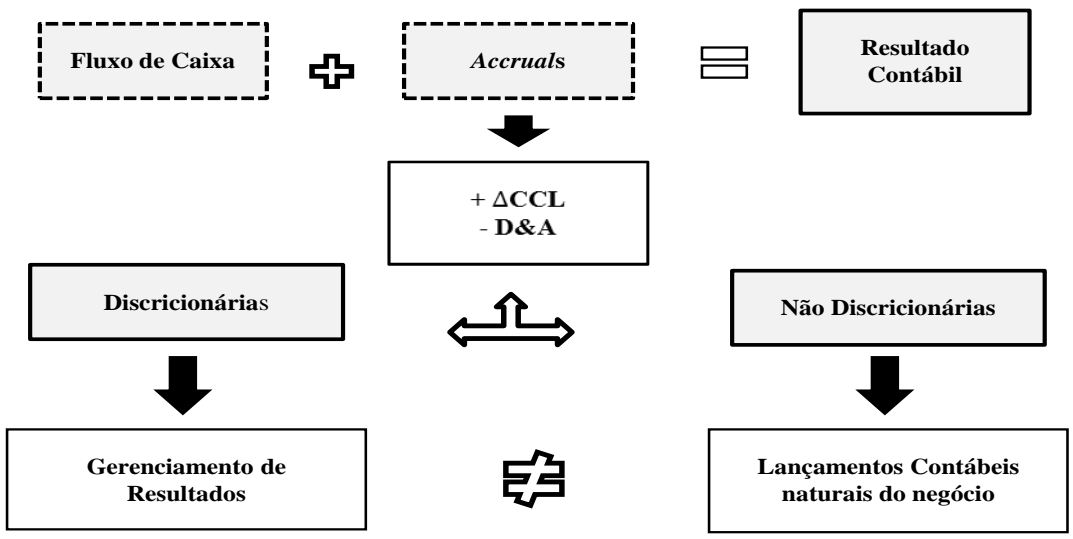

Figura 8 - Diagrama ilustrativo das accruals

Fonte: Adaptado de Martinez (2001, p. 19).

Na Figura 8, nota-se que o fluxo de caixa, item supostamente não manipulável, acrescido das accruals, deriva o resultado contábil, 
seja lucro ou prejuízo. As accruals representam: a) a variação do capital circulante líquido, excluídas, conforme o autor, as disponibilidades e os financiamentos bancários de curto prazo, ou seja, os ativos correntes; b) diminuídas das depreciações e amortizações, ou seja, dos ativos não correntes. As accruals discricionárias representam as proxies de gerenciamento de resultados, enquanto que as accruals não discricionárias representam os lançamentos naturais da atividade da empresa. Conforme Shipper (1989), a diferença entre a accrual discricionária e a accrual não discricionária é fundamental na detecção do gerenciamento de resultados e o erro de classificação pode determinar resultados enganosos.

$\mathrm{O}$ interesse em gerenciar os resultados pode estar relacionado, de acordo com Healy e Wahlen (1999), aos mercados de capitais, às relações contratuais ou às regulamentações. Quanto ao mercado de capitais, os autores sustentam que o uso generalizado das informações contábeis por investidores e analistas financeiros na avaliação das ações pode criar um incentivo para os gestores manipularem os resultados em uma tentativa de influenciar o desempenho de curto prazo das ações.

Quanto às motivações contratuais, um dos incentivos para a prática de gerenciamento de resultados advém dos contratos entre principal e agente. O comportamento oportunístico do gestor, pelo fato de possuir informações privilegiadas se comparado aos stakeholders, em razão dos conflitos de interesses se constitui em forte incentivo para a prática discricionária. Outros contratos também se inserem nessas motivações contratuais, como o contrato com fornecedores de capital, de bens e serviços (JENSEN; MECKLING, 1976).

Quanto aos incentivos regulatórios, Healy e Wahlen (1999) descrevem que o gerenciamento de resultados pode ser de interesse para os organismos de regulação, por duas razões. Primeiro, o gerenciamento de resultados pode potencialmente, por qualquer motivo, induzir a erros nas demonstrações financeiras e afetar a alocação de recursos. Em segundo lugar, relatórios financeiros são usados para a comunicação de informações de gestão, não apenas para os investidores em ações, mas também para os investidores da dívida e de representantes de investidores em conselhos de administração. Os autores acrescentam que surgiram diversos estudos para testar se os incentivos criados pela concessão de empréstimos e contratos de remuneração podem explicar o gerenciamento de resultados. Os estudos apresentam evidências sobre a associação entre os incentivos de contratação e mudanças voluntárias nos métodos de contabilidade, estimativas, ou acréscimos. 
Na Figura 9 evidencia-se um panorama abrangente sobre os temas abarcados pelo gerenciamento de resultados.

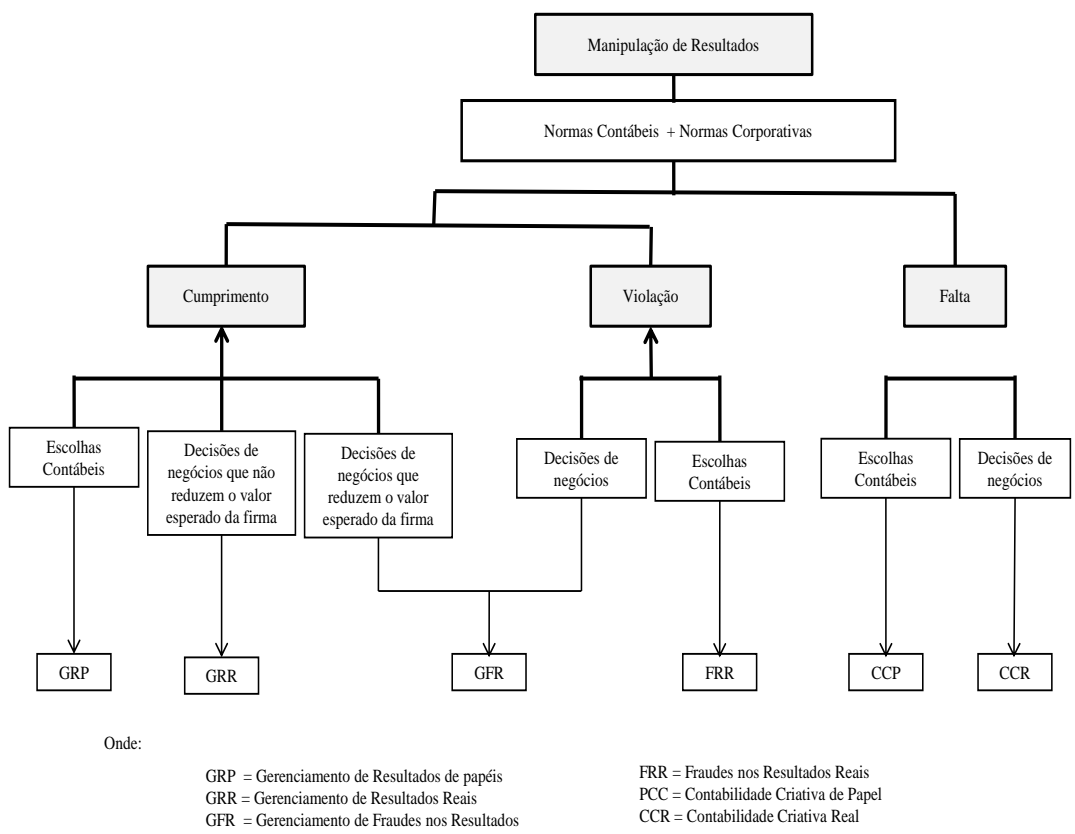

Figura 9 - Relações entre as diversas formas de gerenciamento de resultados

Fonte: Adaptado de Yaping (2005, p.34).

Na Figura 9 observam-se várias divisões e subdivisões da temática do gerenciamento de resultados. A distinção principal está em cumprir, violar ou faltar com as normas contábeis e corporativas.

O Gerenciamento de resultados tem cinco características distintas na definição proposta por Yaping (2005):

a) os resultados são manipulados pela administração, não por contabilistas;

b) os resultados são manipulados consciente e intencionalmente. Assim, a manipulação de resultados é diferente de erros não intencionais, como lançamentos equivocados realizados por contabilistas;

c) as medidas tomadas para a manipulação de resultados incluem não só as escolhas contábeis, mas também as 
decisões reais de negócios. Por exemplo, acelerar as vendas por meio do aumento de descontos nos preços ou em condições de crédito mais brandas, pode levar a empresa a um aumento nos resultados reportados no período corrente, mas uma diminuição no valor da empresa no futuro. O gerenciamento de resultados por meio de decisões de negócios é entendido como gerenciamento de resultados reais, ou manipulação de atividades reais, enquanto que o gerenciamento de resultados por meio de escolhas contábeis é conhecido por gerenciamento de resultados de papéis;

d) o tipo de resultados manipulados no gerenciamento de resultados de papéis envolve resultados reportados, enquanto que o tipo de resultados manipulados na gestão de resultados reais envolve o lucro econômico. No entanto, a finalidade última do gerenciamento de resultados reais é influenciar os resultados contábeis relatados;

e) a extensão dos resultados manipulados depende totalmente do nível de resultados desejados pela administração.

Conforme Yaping (2005), o gerenciamento de resultados tem três formas diferentes: gestão de resultados, fraude nos resultados e contabilidade criativa. As três são exaustivas e mutuamente excludentes.

Para o autor, o gerenciamento de resultados através do exercício do poder discricionário concedido pelas normas contábeis e corporativas é o gerenciamento de resultados de papéis; enquanto que o gerenciamento de resultados das atividades reais ocorre por meio de atividades de reestruturação ou transações comerciais de uma forma legítima. Essas têm tanto um impacto positivo a curto prazo, por exemplo, a adição de um novo produto lucrativo na linha de produção, ou um impacto neutro a longo prazo sobre o valor da empresa no futuro, por exemplo, acelerar o tempo de vendas a preços inalterados.

A manipulação de resultados, que viola as normas contábeis e/ou corporativas, é a gestão de fraude nos resultados. Fraude no resultado real se refere à manipulação de resultados por meio de atividades de reestruturação ou transações de negócios, de tal forma que o valor esperado da empresa seja reduzido, enquanto a reestruturação pode ou não violar as normas corporativas e/ou contábeis (YAPING, 2005).

Transações comerciais que não violem normas de contabilidade ou corporativas, mas reduzem o valor da empresa devem indicar a 
existência de defeitos significativos nos padrões de contabilidade ou de normas corporativas. Por exemplo, algumas normas de contabilidade são incompletas e deixam espaço para manipulação (YAPING, 2005).

O autor exemplifica com o caso da empresa Enron, que nas suas operações de negócios com empresas relacionadas, embora não tenha violado os Princípios de Contabilidade Geralmente Aceitos (GAAPs) ou leis corporativas dos Estados Unidos, reduziu o valor esperado da empresa, pois os riscos da empresa foram aumentados devido a dívidas que aumentaram consideravelmente. $\mathrm{O}$ que a Enron fez é caracterizado como fraude nos resultados reais.

Fraudes nos resultados reais podem ter impactos negativos sobre o valor contábil esperado da empresa, por exemplo, a superprodução, a aceleração de vendas, a redução de preços de venda. Isso aumenta as receitas do período corrente, mas prejudica as receitas do próximo período, e um impacto neutro ou positivo sobre o valor contábil da empresa do período corrente, com um impacto negativo sobre o valor esperado da empresa (YAPING, 2005).

Por fim, a contabilidade criativa, segundo Yaping (2005), ocorre quando, por exemplo, uma norma contábil é muito específica para lidar com as inovações de negócios. Em termos da aplicação das normas de contabilidade e legislação societária, não há sobreposição entre a contabilidade criativa, o gerenciamento de resultados ou a fraude nos resultados. No entanto, em termos de impacto sobre o valor da empresa, sobrepõe-se a contabilidade criativa com o gerenciamento de resultados se não houver diminuição do valor esperado da empresa, e sobrepõe-se com a gestão de fraudes se houver. A contabilidade criativa também pode ser realizada por meio de escolhas contábeis ou de ações reais, o primeiro caso é de contabilidade criativa de papel, enquanto o último é de contabilidade criativa real.

Para Dechow e Skinner (2000), os acadêmicos de contabilidade geralmente têm percepções muito diferentes de gerenciamento de resultados do que os profissionais e os reguladores. Profissionais e reguladores muitas vezes veem o gerenciamento de resultados como uma problemática generalizada, que necessita de medidas corretivas imediatas. Acadêmicos são mais otimistas, não acreditam que o gerenciamento de resultados é ativamente praticado pela maioria das empresas ou que o gerenciamento de resultados não existe necessariamente na preocupação dos investidores. Os autores argumentam que cada um desses grupos pode contribuir de algum modo para repensar suas opiniões sobre o gerenciamento de resultados. 


\subsubsection{Padrões de Gerenciamento de Resultados}

Os padrões de efetivação de gerenciamento de resultados envolvem práticas contábeis ou decisões dos negócios, tais como big bath accounting ou target earnings, que podem se efetivar a partir das accruals ou das atividades operacionais.

\section{a) Big bath accounting ou take a bath}

Martinez (2001) explica que o propósito de gerenciar resultados pela técnica de take a bath accounting ou big bath accounting está relacionado às ações que reduzem o resultado corrente em detrimento de aumentar os resultados futuros.

Explorar a temática de gerenciamento de resultados com o propósito de reduzir o resultado corrente pode ter, por exemplo, o objetivo de assemelhar o resultado realizado ao esperado. Como é o caso da pesquisa de Jaggi e Baydoun (2001), que pesquisaram os itens extraordinários e excepcionais divulgados nas demonstrações financeiras, indicando que as divulgações foram associadas com as expectativas do mercado financeiro, que eram semelhantes ao resultado antes de impostos. Se as expectativas do mercado fossem maiores do que o lucro antes de impostos, os resultados eram suscetíveis de serem divulgados ajustados para cima, reduzindo assim a diferença entre os lucros relatados e os esperados.

Os autores constataram que os gerentes se envolvem em gerenciamento de resultados por meio da divulgação de itens extraordinários quando têm flexibilidade para fazê-lo, a fim de melhorar a qualidade da divulgação financeira. Melhores padrões de contabilidade precisam ser desenvolvidos para a divulgação de itens extraordinários, especialmente por parte dos países recém-desenvolvidos e em desenvolvimento, onde as normas contábeis estão na fase de formação.

Um modo utilizado para atingir o propósito de piorar os resultados inclui o cookie jar reserves. Segundo Cardoso (2005), esta é a situação em que as despesas são provisionadas, com lançamentos em despesas e no passivo, com o intuito de reconhecer no futuro receitas com a reversão das mesmas. Assim cumpre-se o propósito do take a bath, piorando o resultado corrente para melhorar resultados futuros. 


\section{b) Target Earnings}

Conforme Martinez (2001), gerenciar resultados por meio de target earnings significa aumentar ou reduzir os resultados contábeis, com o intuito de melhorar ou piorar, dependendo da ótica a que se propõe o gerenciamento, e esta pode ser efetivada por meio de padrões de gerenciamento, tais como, income maximization, income minimization ou income smoothing.

a) Income maximization - por meio deste padrão de gerenciamento de resultados, os lucros são maximizados (MARTINEZ, 2001). Os objetivos da utilização deste padrão podem ser diversos, incluindo maximizar a remuneração do executivo com base no desempenho da empresa, também para evitar covenants contratuais;

b) Income minimization - conforme Martinez (2001), as empresas podem minimizar os lucros e/ou resultados para, por exemplo, reduzir ou evitar a tributação e pode ser utilizada em período de extrema lucratividade. $\mathrm{O}$ autor esclarece que os padrões de gerenciamento, income maximization e o income minimization são similares ao take a bath, mas não são tão extremos;

c) Income Smoothing - segundo Martinez (2001), significa gerenciar para reduzir a variabilidade nos resultados contábeis. Também é conhecido como meio de alisar ou suavizar os resultados e pode ser utilizado, por exemplo, para evitar surpresas sobre os resultados da empresa, aproximando o resultado realizado do esperado.

Matsumoto (2002) destaca que o gerenciamento de resultados, por meio de práticas de income smoothing, resulta de ações organizacionais dos gestores para evitar surpresas negativas nos resultados. Income smoothing, conforme Cardoso (2005), representa a tentativa de manter os resultados lineares. Esse padrão inclui a utilização de despesas com pesquisa e desenvolvimento, contratos de propaganda, decisões de aquisição de ativos ou consumo de despesas.

Matsumoto (2002) destaca algumas características das empresas que estão associadas com maiores incentivos para evitar surpresas negativas nos resultados: 
a) empresas com maior posse transitória institucional, maior confiança nas afirmações implícitas com as partes interessadas;

b) com maior valor/relevância dos resultados são mais propensos a atender ou superar as expectativas do anúncio dos resultados; e

c) empresas que gerenciam os seus resultados para cima, ou para orientar as previsões dos analistas de mercado financeiro para baixo, de forma a evitar a falta de expectativas no anúncio do resultado final.

A pesquisa realizada por Matsumoto (2002) sobre a probabilidade de uma empresa atender ou superar as previsões dos analistas no anúncio de resultados, bem como para investigar se o tipo de propriedade institucional afeta o incentivo para evitar surpresas negativas nos resultados, confirmou esses pressupostos que desempenham papel importante para evitar surpresas negativas nos resultados.

Burgstahler e Dichev (1997) fornecem evidências, com base em pesquisa, de que empresas gerenciam os resultados divulgados para evitar diminuições nos resultados, podendo utilizar componentes de resultados, tais como o fluxo de caixa das operações e as alterações no capital de giro, de forma a aumentar as receitas.

Roychowdhury (2005) apontou evidências consistentes com a manipulação dos gerentes nas atividades reais para evitar perdas nos relatórios anuais. Especificamente, foram encontrados indícios de: descontos comerciais para aumentar temporariamente as vendas; superprodução para relatar menor custo dos produtos vendidos; redução das despesas discricionárias para melhorar as margens relatadas. Observou também que essas atividades são menos predominantes na presença de investidores sofisticados.

Conforme Roychowdhury (2005), outros fatores que influenciam as atividades de manipulação real incluem: a adesão dos membros da indústria, o saldo de estoques e contas a receber, e incentivos para alcançar o resultado zero. $\mathrm{O}$ autor adverte também para evidências de manipulação de atividades reais a fim de cumprir a previsão anual dos analistas.

A partir desses padrões de gerenciamento de resultados surgem diversas possibilidades de escolhas contábeis ou ações organizacionais. Há também, segundo Paulo (2007), a possibilidade de se observar a distribuição de frequência dos resultados da empresa ao longo do tempo, 
para verificar comportamentos anormais em torno dos pontos de referência, como resultado nulo, por exemplo.

\subsubsection{Incentivos para o Gerenciamento de Resultados}

Conforme Schipper (1989), os incentivos para a prática de gerenciamento de resultados são principalmente de três tipos: incentivos contratuais, incentivos vinculados ao mercado de capitais e incentivos regulamentares.

\section{I) Incentivos Contratuais}

De acordo com Martinez (2001), os incentivos contratuais para a efetivação do gerenciamento de resultados partem do princípio que a contabilidade é um instrumento para monitorar e regular os contratos entre a empresa e os seus diversos stakeholders.

Diversas pesquisas emergiram com essas motivações. Dentre elas, no aspecto da hipótese da dívida, a de Ahmed, Takeda e Thomas (1999), que investigaram a utilização de provisões para perdas em empréstimos por gerentes de instituições financeiras. A finalidade era gerenciar resultados, por meio de capital regulamentar e também sinalizar informações sobre resultados futuros. Nas provisões para perdas de empréstimo foram incluídas:

a) a alteração nos créditos de liquidação duvidosa;

b) a alteração no desvio-padrão implícito de valores de ativos bancários;

c) a alteração de falências de empresas no mercado de um banco.

A pesquisa revelou um forte apoio para a hipótese de que as provisões para perdas com empréstimos são utilizados para o gerenciamento de capital. Entretanto, não foram encontradas evidências de gerenciamento de resultados através de provisões para perdas com empréstimos.

No aspecto da hipótese dos planos de remuneração, tem-se o trabalho seminal de Healy (1985), o qual argumenta que estudos de decisões de gerenciamento de resultados postulam que os executivos são recompensados por bônus com base nas escolhas de procedimentos contábeis que aumentam sua remuneração, produzindo resultados empíricos conflitantes nas pesquisas até aquele momento. Os resultados da pesquisa de Healy (1985) indicaram que: a) as accruals políticas de 
competência dos gestores estão ligadas aos incentivos dos seus contratos de bônus; e b) as mudanças nos procedimentos contábeis pelos gestores estão ligadas à adoção ou modificação de seu plano de bônus.

O estudo de Healy é um passo importante para a compreensão do impacto dos planos de bônus sobre as decisões gerenciais. Extensões possíveis foram discutidas na pesquisa de Healy (1985), destacando a oportunidade de realizar testes ainda mais poderosos sobre o bônus que maximiza a hipótese do comportamento gerencial.

DeGeorge, Patel e Zeckhauser (1999) descrevem que os analistas, investidores e conselhos têm interesse nos relatórios financeiros de resultados, pois estes fornecem informações essenciais para decisões de investimento. Os executivos dos conselhos de administração devem monitorar o desempenho, reconhecendo a importância deste para os investidores da empresa e a conexão com a remuneração dos gestores. Este nexo de relações gera incentivos aos executivos para gerenciar os resultados e para os padrões de resultados divulgados.

II) Incentivos Vinculados ao Mercado de Capitais

Conforme Martinez (2001), a utilização de informações contábeis pelos usuários externos, incluindo os investidores e os analistas de mercado de capitais, para avaliar o preço das ações da empresa gera incentivos para que os administradores gerenciem os resultados contábeis, com o propósito de modificar a percepção de risco a investimentos futuros nas ações da empresa.

Pesquisas nesse tema têm explorado questões relacionadas à hipótese do mercado eficiente. Por exemplo, o estudo de McNichols (1989), que verificou se as informações que os investidores possuem sobre os resultados futuros de uma empresa refletem o preço de suas ações e se refletem na sua previsão de gerenciamento de resultados. Os resultados demonstraram que os retornos das ações no período de previsão do anúncio das informações estão associados positivamente com os erros de previsão de gerenciamento de resultados. No entanto, os preços das ações refletem informações além das previsões de gerenciamento de resultados. Este fenômeno, conforme o autor, pode ocorrer se o gestor não emitir sua previsão verdadeira ou se os investidores têm acesso a algumas informações sobre os rendimentos que os gestores não possuem.

McVay (2006) analisou uma ferramenta potencial de gerenciamento de resultados, que tinha sido ignorada até o momento de 
sua pesquisa, o erro de classificação deliberada de itens dentro da declaração de renda, referido como a técnica de mudança de classificação. A descoberta do autor é consistente com o comportamento de gestores oportunistas que mudam as despesas de gastos essenciais, por exemplo, custo das mercadorias vendidas e das vendas, gerais e administrativas, para itens especiais. Este movimento vertical das despesas não muda o resultado final, mas se reflete no núcleo de resultados. Além disso, parece que os gestores utilizam o gerenciamento de resultados para atender a previsão de resultados dos analistas.

Temas relacionados à oferta inicial pública de ações (Initial Public Offering - IPO) também têm sido exploradas nas motivações vinculadas ao mercado de capitais. Por exemplo, o estudo de Teoh, Welch e Wong (1998) sobre os emissores de ofertas públicas iniciais de ações, fornece evidências de que os emitentes de ações com accruals elevadas e baixo desempenho no ano de experiência IPO, tem baixo retorno de ações em três anos consecutivos.

\section{III) Incentivos Regulamentares}

Segundo Martinez (2001), os incentivos regulamentares podem levar as empresas a gerir seus resultados quando possuem lucros elevados ou acima da média de outros setores.

Pesquisas originadas desta temática têm explorado, por exemplo, a hipótese dos custos políticos, como a de Key (1997), que analisou a indústria de televisão a cabo durante o período de controle do Congresso, obtendo evidências de que os gestores das empresas estão dispostos a reduzir o lucro líquido para mitigar os efeitos de controle político e a regulação potencial sofrida pela indústria. Para o autor, as empresas para as quais as propostas de regulamentação são mais prejudiciais têm maior aumento e/ou decréscimo de despesas.

Libby, Kinney Jr. e William (2000) analisaram se a comunicação do gerente de auditoria reduz a correção oportunística da previsão de gestão de resultados dos analistas de mercado, partindo do pressuposto de que a correção exagerada dos auditores e peritos é menos provável se causar uma previsão baixa, mesmo por distorções objetivamente calculadas. Esse comportamento, de acordo com os autores, é consistente com as preocupações do presidente da SEC sobre correções oportunistas de gerenciamento de resultados com as previsões dos analistas. Além disso, conforme o SAS n ${ }^{\circ}$ 89, a representação e comunicação do gerente não aumentam as correções que causam a previsão não atendida, indicando que o Auditing Standards Board 
limitou a capacidade de reduzir as correções oportunistas através de tais regulamentos.

No âmbito das regulamentações têm-se também os covenants contratuais. DeFond e Jiambalvo (1994) descrevem que as cláusulas contratuais de debt covenants, ou cláusulas de dívidas, destinam-se a restringir os gerentes de se envolverem em investimentos e decisões de financiamento que reduzam o valor dos créditos dos emprestadores, pois os contratos são frequentemente elaborados com base em números contábeis e a violação destas cláusulas tem um custo elevado para o tomador do empréstimo. Assim, administradores de empresas, ao violar as cláusulas de dívida, preferem fazer escolhas contábeis que reduzam a probabilidade de inadimplência.

\subsubsection{Modelos de Mensuração}

Esta subseção apresenta os modelos de mensuração de gerenciamento de resultados, por accruals, por atividades operacionais e por distribuição de frequências. Dentre os mais citados na literatura apresentam-se os abordados por Martinez (2001), Paulo (2007), Baptista (2008) e Machado, Benetti e Bezerra (2011).

I) Modelos de mensuração de gerenciamento de resultados por accruals

a) Modelo de Healy (1985)

O modelo de Healy (1985) foi o primeiro desenvolvido para mensuração das accruals. Conforme Martinez (2001), é um modelo utilizado para estimar o montante discricionariamente alterado, ou seja, estima as accruals agregadas. Segundo Baptista (2008), Healy reconhece que as accruals possuem componentes discricionários e não discricionários. A ideia central é que na ausência de componentes discricionários, que representam a proxy de gerenciamento, o lucro líquido deveria ser igual ao fluxo de caixa operacional. $\mathrm{O}$ modelo de Healy (1985) consiste em:

(Equação 2)

$$
\begin{gathered}
A D_{i t}=A T_{i t}-A N D_{i t} \\
A N D_{i t}=\sum_{i t} \frac{A T_{i t}}{T}
\end{gathered}
$$


Onde:

$A D=$ accruals discricionárias da empresa i no período t;

$A T=$ accruals totais da empresa i no período t;

$A N D=$ accruals não discricionárias da empresa i no período t;

$T=$ número de períodos utilizados para estimar AND.

b) Modelo de DeAngelo (1986)

O modelo de DeAngelo (1986) pode ser considerado como um caso especial do modelo de Healy (1985), pois computa as primeiras diferenças das accruals totais, assume que as primeiras diferenças têm um valor esperado de zero sob a hipótese nula de não gerenciamento de lucros. Este modelo utiliza accruals totais do período passado como medida das accruals não discricionárias, considerando estas constantes de um período para o outro. É assim calculado:

(Equação 3)

$$
A T_{1}-A T_{0}=\left(A D_{1}-A D_{0}\right)-\left(A N D_{1}-A N D_{0}\right)
$$

Onde:

$\mathrm{AT}_{1}=$ accrual total na data $\mathrm{t}=1$, período provável de gerenciamento, accrual supostamente manipulada. Calculada através da diferença entre o Lucro Líquido e o Fluxo de Caixa Operacional em $\mathrm{t}=1$;

$\mathrm{AT}_{0}=$ accrual total na data $\mathrm{t}=0$ benchmark para o que a accrual deveria ser, na ausência de manipulação do lucro. Calculada através da diferença entre o Lucro Líquido e o Fluxo de Caixa Operacional em $\mathrm{t}=0$ (período no qual se espera que não haja manipulação do lucro);

$\mathrm{AT}_{1}-\mathrm{AT}_{0}=$ accrual anormal, a qual é testada se é significativamente negativa (o que, se confirmado, é proxy de gerenciamento para reduzir lucro). Se $A T_{1}-A T_{0}=0$, então $A T_{1}=A T_{0}$, o que significa que as accruals totais são constantes de um período para outro, então não há gerenciamento;

$A D=$ componente discricionário (não observável) das accruals totais;

$\mathrm{AD}_{1}-\mathrm{AD}_{0}=$ diferença entre o componente discricionário da accrual no período no qual se espera não haver manipulação e o 
componente discricionário da accrual no período provável de manipulação;

$A N D=$ componente não discricionário (não observável) das accruals totais;

$\mathrm{AND}_{1}-\mathrm{AND}_{0}=$ diferença entre $\mathrm{o}$ componente não discricionário da accrual no período no qual se espera não haver manipulação e o componente não discricionário da accrual no período provável de manipulação. DeAngelo (1986) assume que esta diferença é igual à zero, ou seja, que as accruals não discricionárias são constantes de um período para o outro.

c) Modelo de McNichols e Wilson (1988)

O modelo de McNichols e Wilson (1988) busca validar o cálculo de accruals, fornecendo uma expressão que mostra que os testes de gerenciamento de resultados podem produzir resultados potencialmente enganosos sob qualquer das duas condições:

a) quando as accruals não discricionárias estão correlacionadas com a variável utilizada para segmentar a amostra em grupos para diferentes comportamentos de gerenciamento de resultados previsíveis;

b) quando as accruals discricionárias são medidas com um grande erro.

A regressão elaborada resulta em:

(Equação 4)

$$
A D_{i t}=\alpha_{0}+\alpha_{1}\left(P A R T_{i t}\right)+\varepsilon_{i t}
$$

Onde:

$A D_{i t}=$ accruals discricionárias da empresa i no período t;

$P A R T_{i t}=$ conjunto de variáveis particionadas que capturam os fatores que presumidamente motiva o gerenciamento das accruals na empresa i no período t;

$\alpha_{0}, \alpha_{1}=$ coeficientes do modelo de regressão;

$\varepsilon_{i, t}=$ termo de erro da regressão que reflete a variação da separação das accruals discricionárias da empresa $i$ no período $t$. 
d) Modelo de Jones (1991)

Jones (1991) refina os modelos anteriores, propondo uma condição que relaxa a suposição de que as accruals não discricionárias são constantes. Seu modelo tenta controlar o efeito das variações da situação econômica de uma empresa em accruals não discricionárias. Os resultados obtidos indicam que o modelo é bem sucedido em explicar cerca de um quarto da variação total dos acréscimos. O modelo pressupõe:

(Equação 5)

$$
\begin{gathered}
A T_{i t}=\alpha_{0}\left(\frac{1}{A_{t-1}}\right)+\alpha_{1}\left(\Delta \operatorname{Rec}_{i t}\right)+\alpha_{2}\left(A T . \operatorname{Imob}_{i t}\right)+\varepsilon_{i t} \\
A N D_{i t}=\alpha_{0}\left(\frac{1}{A_{t-1}}\right)+\alpha_{1}\left(\Delta \operatorname{Rec}_{i t}\right)+\alpha_{2}\left(A T . \text { Imob }_{i t}\right) \\
A D_{i t}=A T_{i t}-A N D_{i t}
\end{gathered}
$$

Onde:

$A T=$ accruals totais da empresa i no período t; accruals totais

$$
\begin{aligned}
& \text { = Acapital circulante líquido } \\
& \text { - depreciação e amortização }
\end{aligned}
$$

$A_{t-1}=$ ativos totais em t a t-1;

$\Delta \operatorname{Rec}_{i t}=$ receitas operacionais líquidas da empresa $\mathrm{i}$ no ano $\mathrm{t}$ menos receitas nos anos t-1 escalada pelos Ativos de $\mathrm{t}-1$;

At. Imob = ativo imobilizado da empresa i no ano t; $A N D=$ accruals não discricionárias da empresa i no período t; $A D=$ accruals discricionárias da empresa i no período t; $\alpha_{0}, \alpha_{1}, \alpha_{2}=$ coeficientes estimados por regressão; $\varepsilon_{i t}=$ erro da regressão.

e) Modelo de Dechow, Sloan e Sweeney (1995)

Dechow, Sloan e Sweeney (1995) aperfeiçoaram o modelo de Jones, que também é conhecido como modelo de Jones modificado, extraindo as contas a receber da parte não discricionária do modelo original. De acordo com Martinez (2001), Paulo (2007) e Baptista (2008), o modelo de Jones modificado é o mais utilizado nas pesquisas 
em gerenciamento de resultados relativas à identificação e mensuração das accruals, e o novo cálculo resulta em:

(Equação 6)

$$
A T_{i t}=\alpha_{0}+\alpha_{1}\left(\Delta \operatorname{Rec}_{i t}-\Delta C \cdot \operatorname{Receb}_{i t}\right)+\alpha_{2}\left(A T \cdot \operatorname{Imob}_{i t}\right)+\varepsilon_{i t}
$$

Onde:

$A T=$ accruals totais da empresa i no período t; accruals totais

$$
\begin{aligned}
& \text { = Acapital circulante líquido } \\
& \text { - depreciação e amortização }
\end{aligned}
$$

$\Delta R e c_{i t}=$ variação das receitas operacionais líquidas da empresa i entre o período t e t- 1 ;

$\Delta C \cdot$ Receb $_{i t}=$ variação das contas a receber líquidas da empresa i entre o período t e t-1;

At. Imob = ativo imobilizado operacional da empresa i no ano $\mathrm{t}$

$\alpha_{0}, \alpha_{1}, \alpha_{2}=$ coeficientes estimados por regressão.

$\varepsilon_{i t}=$ erro da regressão

OBS: todas as variáveis são escaladas pelos ativos totais em t-1.

Destaca-se que o modelo original possui a variável GPPE, que se origina da conta patrimonial gross property plant and equipment, a qual não existe no Brasil. Assim, na apresentação da fórmula esta foi substituída pelo ativo imobilizado operacional.

f) Modelo de Kang e Sivaramakrishnan (1995)

Os modelos propostos para testar o gerenciamento de resultados apresentavam até então falhas, uma vez que sofriam de problemas de simultaneidade, erros de mensuração de variáveis ou problemas com variáveis omitidas. Segundo Kang e Sivaramakrishnan (1995), qualquer um destes problemas é factível de diminuição de seu poder estatístico de comprovação e também pode distorcer as inferências sobre o gerenciamento de resultados. Os autores reduziram esses problemas por meio de um novo método, que ampliou o modelo de Jones modificado, tornando-se o modelo de Jones ampliado, incluindo variáveis explicativas que refletem a realidade econômica da empresa. O modelo 
utiliza as principais contas de resultados como regressores na sua formulação, conforme descrito na fórmula a seguir:

(Equação 7)

$$
\begin{gathered}
A T_{i t}=\alpha_{0}+\alpha_{1}\left[\delta_{1} \operatorname{Rec}_{i t}\right]+\alpha_{2}\left[\delta_{2} \text { Desp }_{i t}\right]+\alpha_{3}\left[\delta_{3} \text { At. Imob } b_{i t}\right] \\
+\alpha_{4} \text { Part }_{i t}+\varepsilon_{i t}
\end{gathered}
$$

Onde:

$A T_{i t}=$ accruals totais da empresa $\mathrm{i}$ no período $\mathrm{t}\left(C G L_{i t}-\right.$ depreciação e amortização);

$R e c_{i t}=$ receita líquida (excluindo tributação) da empresa i no período t;

Desp $p_{i t}=$ custos e despesas operacionais antes da depreciação e amortização da empresa i no período t;

At. Imob $_{i t}=$ ativo imobilizado e ativo diferido da empresa i no período t;

Part $_{i t}=$ variável dummy que captura os fatores que motivam o gerenciamento. Na ausência de gerenciamento de resultados assume valor igual a 0 . Part $_{i t}=1$ para o período no qual a quantidade de accruals foi acrescentada;

$C G L_{i t}=$ capital de giro líquido, excluindo as disponibilidades, financiamentos de curto prazo e provisão de impostos a pagar da empresa i no período t;

$\delta_{1}=\frac{C \cdot \operatorname{Receb}_{i t-1}}{\operatorname{Rec}_{i t-1}}$

$\delta_{2}=\frac{\left(E s t q_{i t-1}+O A C_{i t-1}+C \cdot \text { Pagar }_{i t-1}\right)}{\operatorname{Desp}_{i, t-1}}$

$\delta_{3}=\frac{\text { Deprec }_{i t-1}}{\text { At. Imob }}$

C. Receb $_{i t-1}=$ contas a receber, excluídos reembolsos de impostos, da empresa i no período t-1;

$R e c_{i t}=$ receitas operacionais líquidas da empresa i no período $\mathrm{t}-1$;

$E s t q_{i t-1}=$ estoques da empresa i no período $\mathrm{t}-1$;

$O A C_{i t-1}=$ outros ativos correntes, exceto caixa, contas a receber e estoque da empresa i no período t-1;

C. Pagar $_{i t-1}=$ contas a pagar, excluindo-se impostos e porção da dívida de longo prazo que vence no curto prazo, da empresa i no período t-1; 
Deprec $_{i t-1}=$ despesas de depreciação da empresa i no período $\mathrm{t}-1$;

At. Imo $_{i t-1}=$ ativo imobilizado e ativo diferido da empresa i no período t-1;

$\alpha_{0}, \alpha_{1}, \alpha_{2}, \alpha_{3}, \alpha_{4}=$ coeficientes estimados por regressão;

$\varepsilon_{i t}=$ erro da regressão;

Rec, Desp, At. Imob. $=$ são escaladas pelos ativos totais.

g) Modelo de Pae (2005)

O modelo de Pae (2005) complementa o modelo de Jones (1991), com a incorporação do fluxo de caixa operacional e accruals totais defasadas, para avaliar o impacto da: a) associação negativa entre accruals e fluxo de caixa simultaneamente; b) associação positiva entre accruals e fluxo de caixa defasado; e c) reversão de provisões. $\mathrm{O}$ objetivo é melhorar o poder explicativo e preditivo do modelo de Jones (1991). Esse modelo está representado na fórmula a seguir:

(Equação 8)

$$
\begin{gathered}
A T_{i t}=\alpha_{0}+\alpha_{1}\left(\Delta \operatorname{Rec}_{i t}-\Delta C \cdot \text { Receb }_{i t}\right)+\alpha_{2} A \cdot \text { Imob }_{i t}+\lambda_{0} F C x_{i t} \\
+\lambda_{1 i} F C x_{i t-1}+\lambda_{2 i} A T_{i t-1}+\varepsilon_{i t}
\end{gathered}
$$

Onde:

$A T_{i t}=$ accruals totais da empresa i no período $\mathrm{t}$,

$\Delta R e c_{i t}=$ variação da receita da empresa i entre o período t e t1

$\Delta C \cdot$ Rece $_{i t}=$ variação das contas a receber da empresa i entre o período t e t-1;

A. Imob $_{\text {it }}=$ ativo imobilizado bruto da empresa i no período t;

$F C x_{i t}=$ fluxo de caixa da empresa i no período t, escalado pelos ativos totais;

$F C x_{i t-1}=$ fluxo de caixa da empresa i no período $\mathrm{t}-1$;

$A T_{i t-1}=$ accruals totais da empresa i no período $\mathrm{t}-1$;

$\alpha_{0}, \alpha_{1}, \alpha_{2}, \lambda_{0}, \lambda_{1}, \lambda_{2}=$ coeficientes do modelo de regressão;

$\varepsilon_{i t}=$ erro da regressão;

Rec, C.Receb, At.Imob, Fcx = são escaladas pelos ativos totais. 
Os modelos descritos nesta subseção não esgotam a literatura sobre o tema, são apenas alguns dos mais utilizados e mais citados em pesquisas nacionais e internacionais (MACHADO; BENETTI; BEZERRA, 2011).

II) Modelos de mensuração de gerenciamento de resultados por atividades operacionais

a) Modelo de Dechow, Richardson e Tuna (2003)

O modelo de Dechow, Richardson e Tuna (2003) foi desenvolvido para o cálculo do nível de gerenciamento de resultados por accruals totais para o segmento de empresas industriais, conforme equação a seguir:

(Equação 9)

$$
\begin{gathered}
\frac{A T_{i t}}{A \cdot T l_{i t-1}}=\frac{a_{0}}{A \cdot T l_{i t-1}}+a_{1} \frac{(1+K) \Delta R e c_{i t}-\Delta C \cdot \operatorname{Receb}_{i t}}{A \cdot T l_{i t-1}}+a_{2} \frac{A \cdot \operatorname{Imob}_{i t}}{A \cdot T l_{i t-1}} \\
+a_{3} \frac{A T_{i t-1}}{A \cdot T l_{i t-2}}+a_{4} \frac{\Delta R e c_{i t}+1}{\operatorname{Rec}_{i t}}+\varepsilon_{i t}
\end{gathered}
$$

Onde:

$A T_{i t}=$ accruals totais da empresa i no período t;

$A . T l_{i t}=$ ativo total da empresa i no período t-1;

$K=$ coeficiente de inclinação estimado a partir da regressão $\Delta R e c=\Delta C$. Receb para cada grupo de indústria/ano a partir de Fama e French (1997) $\Delta R e c=\alpha+K \Delta \operatorname{Rec}+\varepsilon$

$\Delta R e c_{i t}=$ variação nas vendas da empresa i no período t e t -1 ;

$\Delta C$. Rece $b_{i t}=$ variação nas contas a receber da empresa i no período t e t-1;

$A \cdot$ Imob $_{i t}=$ ativo imobilizado (planta e equipamentos) da empresa i no período $t$;

$A T_{i t-1}=$ accruals totais da empresa i no período $\mathrm{t}-1$;

$\alpha_{0}, \alpha_{1}, \alpha_{2}, \alpha_{3}, \alpha_{4}=$ coeficientes estimados por regressão;

$\varepsilon_{i t}=$ erro da regressão. 
b) Modelo de Anderson, Banker e Janakiraman (2003)

O modelo de Anderson, Banker e Janakiraman (2003) foi desenvolvido para estimar a manipulação real nas decisões operacionais relativas a despesas com vendas, gerais e administrativas. A equação é assim descrita:

(Equação 10)

$$
\begin{gathered}
\log \left(\frac{D V G A d m_{i t}}{D_{A G A d m_{i t-1}}}\right)=\alpha_{1}+\alpha_{2} \log \left(\frac{\operatorname{Rec}_{i t}}{\operatorname{Rec}_{i t-1}}\right)+ \\
\alpha_{3} \log \left(\frac{\operatorname{Rec}_{i t}}{\operatorname{Rec}_{i t-1}}\right) x D S_{i t}+\alpha_{4} \log \left(\frac{\operatorname{Rec}_{i t-1}}{\operatorname{Rec}_{i t-2}}\right) \\
+\alpha_{5} \log \left(\frac{\operatorname{Rec}_{i t-1}}{\operatorname{Rec}_{i t-2}}\right) x D S_{i t-1}+\varepsilon_{i t}
\end{gathered}
$$

Onde:

$\log =$ logaritmo

DVGAdm $m_{i t}=$ despesas com vendas, gerais e administrativas da empresa i no período $\mathrm{t}$;

$D V G A d m_{i t-1}=$ despesas com vendas, gerais e administrativas da empresa i no período t-1;

$R e c_{i t}=$ receita líquida da empresa i no período $\mathrm{t}$;

$R e c_{i t-1}=$ receita líquida da empresa i no período $\mathrm{t}-1$;

$D S_{i t}=$ variável categórica que indica o comportamento da receita líquida da empresa $\mathrm{i}$ no período $\mathrm{t}$, sendo 1 quando $R e c_{i t}<R e c_{t-1}$ e 0 quando contrário;

$D S_{i t-1}=$ variável categórica que indica o comportamento da receita líquida da empresa $\mathrm{i}$ no período $\mathrm{t}-1$, sendo 1 quando $\operatorname{Rec}_{i t-1}<\operatorname{Rec}_{i t-2}$ e 0 quando contrário; $\alpha_{0}, \alpha_{1}, \alpha_{2}, \alpha_{3}, \alpha_{4}=$ coeficientes estimados por regressão; $\varepsilon_{i t}=$ erro da regressão.

c) Modelo de Gunny (2003)

O modelo de Gunny (2005) serve para estimar a manipulação real nas decisões operacionais relativas às despesas com pesquisa e desenvolvimento. É representado na equação descrita a seguir: 
(Equação 11)

$$
\begin{array}{ll}
\frac{P \& D_{i t}}{A . T l_{i t-1}} & \\
& =\alpha_{0}+\alpha_{1} \frac{P \& D_{i t-1}}{A . T l_{i t-1}}+\alpha_{2} \frac{F . I n t_{i t}}{A \cdot T l_{i t-1}} \\
& +\alpha_{3} \text { QTobin }_{i t}+\alpha_{4} \frac{\text { Cap }_{i t}}{A \cdot T l_{i t-1}}+\varepsilon_{i t}
\end{array}
$$

Onde:

$P \& D_{i t}=$ despesas com pesquisa e desenvolvimento da empresa i no período t;

$A . T l_{i t-1}=$ ativo total da empresa i no período $\mathrm{t}-1$;

$P \& D_{i t-1}=$ despesas com pesquisa e desenvolvimento da empresa i no período t-1;

$F$. Int $=$ fundos internos correspondem ao lucro operacional adicionado das despesas com pesquisa e desenvolvimento e acrescido das despesas de depreciação e amortização;

QTobin $_{i t}=$ valor de mercado da empresa $\mathrm{i}$ no período $\mathrm{t}$ dividido pelo custo de reposição de seus ativos;

$D C a p_{i t}=$ despesas de capital da empresa i no período t; $\alpha_{0}, \alpha_{1}, \alpha_{2}, \alpha_{3}, \alpha_{4}=$ coeficientes estimados por regressão; $\varepsilon_{i t}=$ erro da regressão.

d) Modelo de Roychowdhury (2005)

O modelo de Roychowdhury (2005) foi desenvolvido para estimar a manipulação real nas decisões operacionais relativas ao nível de produção. Está descrito na equação a seguir:

(Equação 12)

$$
\begin{gathered}
\frac{\operatorname{Prod}_{i t}}{A \cdot T l_{i t-1}} \\
=\alpha_{0}+\alpha_{1} \frac{1}{A \cdot T l_{i t-1}}+\alpha_{2} \frac{\operatorname{Rec}_{i t}}{A \cdot T l_{i t-1}} \\
+\alpha_{3} \frac{\Delta R e c_{i t}}{A \cdot T l_{i t-1}}+\alpha_{4} \frac{\Delta R e c_{i t-1}}{A \cdot T l_{i t-1}}+\varepsilon_{i t}
\end{gathered}
$$


Onde:

$\operatorname{Prod}_{i t}=$ custo dos produtos vendidos da empresa i no período $\mathrm{t}$, acrescido da variação dos estoques do período t para t-1;

$A \cdot T l_{i t-1}=$ ativo total da empresa i no período t -1 ;

$R e c_{i t}=$ receita líquida da empresa i no período $\mathrm{t}$;

$R e c_{i t-1}=$ receita líquida da empresa i no período $\mathrm{t}-1$;

$\Delta \operatorname{Rec}_{i t}=$ variação da receita líquida da empresa $\mathrm{i}$ entre $\mathrm{o}$ período t e t-1;

$\alpha_{0}, \alpha_{1}, \alpha_{2}, \alpha_{3}, \alpha_{4}=$ coeficientes estimados por regressão;

$\varepsilon_{i t}=$ erro da regressão.

III) Modelos de mensuração de gerenciamento de resultados por distribuição de frequências

Burgsthaler e Dichev (1997) são os precursores de outra forma de verificar a existência de gerenciamento de resultados, que não o uso das accruals, mas com base na distribuição cross-sectional, ou seja, por meio de um histograma da distribuição e da variação dos lucros, verificando comportamentos anormais ao redor de um ponto de referência. Na pesquisa dos autores foram encontradas evidências de gerenciamento de resultados, por meio de comportamentos anormais na distribuição do fluxo de caixa das operações e nas alterações do capital de giro, com o objetivo de aumentar a remuneração do executivo e evitar reportar perdas.

Após a descrição dos principais modelos de detecção e mensuração de gerenciamento de resultados elencados pela literatura internacional, apresentam-se estudos anteriores sobre o gerenciamento de resultados sob a ótica dos planos de remuneração de executivos.

2.2.3.4 Estudos Anteriores - Gerenciamento de Resultados e Remuneração de Executivos

Os estudos anteriores referem-se à aplicação em pesquisas do aporte teórico apresentado relativo ao gerenciamento de resultados associado às motivações contratuais, especificamente dos planos de remuneração de executivos. 
a) Pesquisas publicadas em periódicos nacionais

Estudos anteriores realizados nacionalmente foram selecionados em periódicos de contabilidade classificados pelo Webqualis da Coordenação de Aperfeiçoamento de Pessoal de Nível Superior (CAPES) (2012) nos estratos A2, B1, e B2, no período relativo à primeira edição de cada periódico até o final de março de 2012, apresentados no Quadro 6.

\begin{tabular}{|l|c|c|}
\hline \multicolumn{1}{|c|}{ Periódicos Nacionais } & Responsável & Qualis \\
\hline Brazilian Business Review - BBR & FUCAPE & A2 \\
\hline Revista de Contabilidade \& Finanças - RC\&F & USP/SP & A2 \\
\hline Contabilidade Vista \& Revista - CVR & UFMG & B1 \\
\hline Revista Brasileira de Finanças - RBF & FGV & B1 \\
\hline Revista Brasileira de Gestão de Negócios - RBGN & FECAPE & B1 \\
\hline Revista de Contabilidade e Organizações - RCO & USP/RP & B1 \\
\hline Revista Universo Contábil - RUC & FURB & B1 \\
\hline Revista de Administração e Contabilidade - BASE & UNISINOS & B2 \\
\hline Contabilidade, Gestão e Governança - CGG & UnB & B2 \\
\hline Enfoque: Reflexão Contábil & UEM & B2 \\
\hline
\end{tabular}

Quadro 6 - Periódicos nacionais - gerenciamento de resultados e planos de remuneração

Fonte: CAPES (2012).

A busca de artigos nos 10 periódicos listados no Quadro 6 foi direcionada pela procura das palavras 'earnings management', 'gerenciamento de ganhos', 'gerenciamento de lucros' e 'gerenciamento de resultados', no título, resumo ou palavras-chave.

Além dos periódicos listados no Quadro 6, foram revisados também a Revista de Educação e Pesquisa em Contabilidade e a Revista de Informação Contábil.

O período compreendido pela busca abrange desde a criação dos periódicos, ou seja, sua primeira edição, até a edição disponibilizada eletronicamente em final de março de 2012.

Foram encontrados 33 artigos sobre o tema gerenciamento de resultados e destes extraídos os de gerenciamento de resultados associados aos planos de remuneração de executivos, listados no Quadro 7. 


\begin{tabular}{|l|l|}
\hline \multicolumn{1}{|c|}{ Autores (ano) } & \multicolumn{1}{|c|}{ Título } \\
\hline $\begin{array}{l}\text { Matos e Sancovschi } \\
\text { (2005) }\end{array}$ & $\begin{array}{l}\text { Earnings management: the case of Lucent } \\
\text { Technologies. }\end{array}$ \\
\hline Cupertino (2006) & $\begin{array}{l}\text { Earnings management: estudo de caso do Banco } \\
\text { Nacional. }\end{array}$ \\
\hline
\end{tabular}

Quadro 7 - Pesquisas nacionais - gerenciamento de resultados e planos de remuneração

Fonte: Elaborado a partir da literatura pesquisada.

Dos 33 artigos localizados, apenas dois tangenciaram o tema de gerenciamento de resultados com remuneração de executivos e estão sumariados a seguir.

A pesquisa de Matos e Sancovschi (2005), um estudo de caso na empresa estadunidense de tecnologia Lucent, revisou concisamente a literatura sobre o gerenciamento de lucros, mostrando os incentivos e a mecânica, usados pelos gerentes da empresa para manipular os lucros. Os resultados demonstraram incentivos fortes para os gerentes da Lucent informarem lucros fáceis e crescentes para: a) aumentar a capitalização do mercado da empresa; b) fortalecer a compensação de gerenciamento e a garantia de emprego; e c) reduzir o custo do capital da companhia.

A evidência encontrada sugere que os gestores, para gerenciar os lucros, usaram: a) a estratégia de big bath para os custos de reestruturação; b) reservas diversas do tipo cookie jar; c) o reconhecimento prematuro e agressivo da renda; e d) a contabilidade de aquisição criativa e o P\&D adquirido.

O estudo de Cupertino (2006) promoveu um estudo de caso em uma das maiores instituições financeiras brasileiras da década de 90, o Banco Nacional S.A. (BNSA), visando investigar a gestão fraudulenta de lucros, tanto nos seus aspectos motivadores, quanto em relação aos seus efeitos na composição patrimonial da entidade. $\mathrm{O}$ autor constatou que pode haver interesses inconciliáveis entre o agente e o principal, conforme disciplinado pela teoria da agência e ressalta a importância do conhecimento dos dados financeiros na identificação dos fatos de interesse, dos ajustes pertinentes e da correta evidenciação da situação patrimonial da entidade.

b) Pesquisas publicadas em periódicos internacionais

$\mathrm{Na}$ busca por pesquisas internacionais investigaram-se periódicos internacionais de contabilidade, disponibilizados no portal de 
periódicos da CAPES (2011), que estão indexados ao Journal Citation Report (JCR), conforme se verifica no Quadro 8. O período de análise corresponde a 16 anos, compreendidos entre 1995 e 2010.

\begin{tabular}{|l|}
\hline \multicolumn{1}{|c|}{ Periódicos indexados ao JCR } \\
\hline Abacus - A Journal of Accounting, Finance and Business \\
\hline Accounting, Organizations and Society \\
\hline Journal of Accounting and Economics \\
\hline Journal of Business Finance and Accounting \\
\hline The Accounting Review \\
\hline Review of Accounting Studies \\
\hline
\end{tabular}

Quadro 8 - Periódicos internacionais - gerenciamento de resultados e planos de remuneração

Fonte: CAPES (2011).

A amostra compreendeu os artigos sobre a temática earnings management de seis periódicos internacionais de contabilidade. A busca foi no título, resumo e palavras-chave dos artigos, direcionada pelas palavras: earnings management, accounting choices, manage earnings, accruals, earnings, discrecionary spending decisions, earnings forecasts, changing accounting numbers, earnings manipulation, accounting changes, accounting decisions, accounting earnings, accounting procedure, discrecionary behavior, manipulation of earnings, firms choice, smoothing, adoption choices, incentives to manage earnings, selection of accounting principles, earning surprise, management of earnings, management's incentives, managing earnings, accounting income numbers, accounting numbers.

Os artigos selecionados sobre o tema de gerenciamento de resultados com remuneração de executivos estão listados no Quadro 9.

\begin{tabular}{|l|l|}
\hline \multicolumn{1}{|c|}{ Autores (ano) } & \multicolumn{1}{|c|}{ Título da pesquisa } \\
\hline $\begin{array}{l}\text { Gaver, Gaver e } \\
\text { Austin (1995) }\end{array}$ & $\begin{array}{l}\text { Additional evidence on bonus plans and income } \\
\text { management. }\end{array}$ \\
\hline $\begin{array}{l}\text { Holthausen, Larcker } \\
\text { e Sloan (1995) }\end{array}$ & $\begin{array}{l}\text { Annual bones schemes and the manipulation of } \\
\text { earnings. }\end{array}$ \\
\hline Wallace (1997) & $\begin{array}{l}\text { Adopting residual income-based compensation plans: } \\
\text { do you get what you pay for? }\end{array}$ \\
\hline $\begin{array}{l}\text { Guidry, Leone e } \\
\text { Rock (1999) }\end{array}$ & $\begin{array}{l}\text { Earnings-based bonus plans and earnings management } \\
\text { by business-unit managers. }\end{array}$ \\
\hline
\end{tabular}




\begin{tabular}{|c|c|}
\hline Healy (1999) & $\begin{array}{l}\text { Discussion of earnings-based bonus plans and } \\
\text { earnings management by business unit managers. }\end{array}$ \\
\hline $\begin{array}{l}\text { Abbody e Kasznik } \\
(2000)\end{array}$ & $\begin{array}{l}\text { CEO stock option awards and the timing of corporate } \\
\text { voluntary disclosures. }\end{array}$ \\
\hline Murphy (2001) & Performance standards in incentive contracts. \\
\hline Bens et al. (2003) & $\begin{array}{l}\text { Employee stock options, EPS dilution, and stock } \\
\text { repurchases. }\end{array}$ \\
\hline $\begin{array}{l}\text { Hanlon, Rajgopal e } \\
\text { Shevlin (2003) }\end{array}$ & $\begin{array}{l}\text { Are executive stock options associated with future } \\
\text { earnings? }\end{array}$ \\
\hline Larcker (2003) & $\begin{array}{l}\text { Discussion of employee stock options, EPS dilution, } \\
\text { and stock repurchases. }\end{array}$ \\
\hline $\begin{array}{l}\text { Nagar, Nanda e } \\
\text { Wysicki (2003) }\end{array}$ & Discretionary disclosure and stock-based incentives. \\
\hline $\begin{array}{l}\text { Bartov e Mohanram } \\
\text { (2004) }\end{array}$ & $\begin{array}{l}\text { Private information, earnings manipulations, and } \\
\text { executive stock-option exercises. }\end{array}$ \\
\hline $\begin{array}{l}\text { Cheng e Warfield } \\
(2005)\end{array}$ & Equity incentives and earnings management. \\
\hline $\begin{array}{l}\text { Coles, Hertzel e } \\
\text { Kalpathy (2006) }\end{array}$ & $\begin{array}{l}\text { Earnings management around employee stock option } \\
\text { reissues. }\end{array}$ \\
\hline $\begin{array}{l}\text { Comprix e Muller } \\
\text { (2006) }\end{array}$ & $\begin{array}{l}\text { Asymmetric treatment of reported pension expense and } \\
\text { income amounts in CEO cash compensation } \\
\text { calculations. }\end{array}$ \\
\hline $\begin{array}{l}\text { Hunton, Mauldin e } \\
\text { Wheeler (2008) }\end{array}$ & $\begin{array}{l}\text { Potential functional and dysfunctional effects of } \\
\text { continuous monitoring. }\end{array}$ \\
\hline $\begin{array}{l}\text { Mcanally, Srivastava } \\
\text { e Weaver (2008) }\end{array}$ & $\begin{array}{l}\text { Executive stock options, missed earnings targets, and } \\
\text { earnings management. }\end{array}$ \\
\hline $\begin{array}{l}\text { Carter, Lynch e } \\
\text { Zechman (2009) }\end{array}$ & $\begin{array}{l}\text { Changes in bonus contracts in the post-Sarbanes- } \\
\text { Oxley era. }\end{array}$ \\
\hline Kalyta (2009) & $\begin{array}{l}\text { Accounting discretion, horizon problem, and CEO } \\
\text { retirement benefits. }\end{array}$ \\
\hline Laux e Laux (2009) & $\begin{array}{l}\text { Board committees, CEO compensation, and earnings } \\
\text { management. }\end{array}$ \\
\hline
\end{tabular}

\section{Quadro 9 - Pesquisas internacionais - gerenciamento de resultados e planos de remuneração}

Fonte: Elaborado a partir da literatura pesquisada.

A busca resultou em 288 artigos, dentre estes 20 foram desenvolvidos sobre a temática de gerenciamento de resultados associados aos planos de remuneração de executivos, e estão sinteticamente descritos a seguir.

Gaver, Gaver e Austin (1995) estenderam a pesquisa de Healy (1985) examinando a relação entre accruals discricionárias e os limites de bônus para uma amostra de 102 empresas dos Estados Unidos, no 
período 1980-1990. Os resultados foram mais consistentes com a hipótese de suavização de receitas do que com a hipótese de planos de bônus de Healy.

Holthausen, Larcker e Sloan (1995) usaram dados confidenciais de planos de remuneração de executivos dos Estados Unidos, especificamente sobre bônus de curto prazo. Investigaram até que ponto os executivos manipulam os lucros para maximizar o valor presente dos pagamentos de seus planos de bônus. Como Healy, os autores encontraram evidências consistentes com a hipótese de que os gerentes manipulam os lucros para menos quando seus bônus estão no seu máximo. Os autores demonstraram que os resultados de Healy, no limite inferior são susceptíveis de indução por sua metodologia utilizada.

Wallace (1997) testou empiricamente o uso do lucro residual como medida de desempenho, confrontando duas amostras, uma das empresas que começaram a usar esta metodologia como indicador para os planos de remuneração, outra de empresas que continuam a usar os lucros contábeis tradicionais, todas elas empresas estadunidenses. Os resultados suportam hipóteses de ações gerenciais associadas ao desempenho com base no lucro residual como medida de incentivo.

Guidry, Leone, e Rock (1999) testaram a hipótese de maximização de bônus que os gestores de um conglomerado de empresas multinacionais fazem com decisões discricionárias de competência para maximizar o seu bônus de curto prazo. Usando informações de gestão e do banco de dados de relatórios financeiros de um grande conglomerado, estenderam investigações anteriores de duas maneiras. Primeiro, a análise foi conduzida usando a unidade de negócios em nível de dados, o que reduz o problema de agregação que é provável que surja quando se utiliza nível de dados da empresa de forma mais ampla. Em segundo lugar, os gerentes dessa configuração foram pagos com bônus baseados, unicamente, no lucro da unidade de negócios. Os efeitos potenciais da associação do desempenho de longo prazo e a remuneração baseada em incentivos de ações estão, portanto, ausentes. Estas investigações produziram evidências robustas que corroboram com as de Healy (1985).

Healy (1999) discute a pesquisa de Guidry, Leone e Rock (1999) sobre dados da unidade de negócios para reexaminar se os planos de remuneração baseados em bônus estão associados ao gerenciamento de resultados. A contribuição dos autores, conforme Healy (1999), está em aumentar o poder dos testes de controle de incentivos para gerenciamento de resultados previsto pela remuneração baseada em ações e inclui: a) a generalização dos achados além da amostra da 
empresa, b) a significância econômica do gerenciamento de resultados, c) o efeito da gestão de resultados em prêmios de bônus, como nível de grupo de incentivos para gerir lucros, interagindo com incentivos ao nível da unidade de negócios.

Abbody e Kasznik (2000) investigaram se os CEOs estadunidenses gerenciam o ritmo de suas divulgações voluntárias em torno da opção de prêmios em ações. Os autores presumem que os CEOs gerenciam as expectativas dos investidores em torno das datas de prêmios em opções de ações, atrasando uma notícia boa e antecipando uma notícia ruim. Para uma amostra de 2.039 CEOs com prêmios de opção em 572 firmas com prêmio fixo agendado, os resultados sugerem que os CEOs tomam decisões de divulgação voluntária oportunista, que maximiza sua remuneração de opção de ações.

Murphy (2001) focou sua pesquisa na remuneração por padrão de desempenho e mostrou que as empresas escolhem padrões externos quando o desempenho é uma estimativa prévia não confiável do desempenho contemporâneo. Além disso, as empresas dos Estados Unidos, que utilizam como base o orçamento e outros padrões de desempenho determinados internamente, têm pay-outs menos variáveis de bônus, e é mais provável suavizar ganhos nestas do que em empresas que utilizam padrões determinados externamente.

Bens et al. (2003) investigaram nos Estados Unidos se as decisões de recompra de ações dos executivos são afetadas por seus incentivos para gerenciar lucros diluídos nos ganhos por ação. Os resultados demonstraram que os executivos aumentam o nível de recompra de ações de suas empresas quando: a) o efeito diluidor das opções de ações em circulação dos empregados aumenta o ganho diluído por ação; e b) os lucros estão abaixo do nível exigido para alcançar a taxa desejada de crescimento de ganhos por ação. Também, encontraram decisões de recompra dos executivos que não são associadas com exercícios de opções de ações reais de empregados, sugerindo que eles são movidos por diluição de incentivos para gerenciar, fortalecendo a interpretação de gerenciamento de resultados.

Hanlon, Rajgopal e Shevlin (2003), pesquisadores dos Estados Unidos, estimaram a relação entre os subsídios de opções de ações de empregados dos cinco executivos principais e os ganhos futuros para examinar se o alinhamento de incentivos, ou de extração de renda, pelos gestores de primeira linha explica o comportamento das opções de concessão. Os pagamentos para opções de ações de empregados parecem ser impulsionados, predominantemente, pelos determinantes 
econômicos de concessões de opções e não pela baixa qualidade de governança.

Larcker (2003), ao discutir a pesquisa de Bens et al. (2003), destaca que a conclusão dos autores, de que as decisões de recompra de ações estão relacionadas ao impacto das opções de ações sobre a capacidade das empresas para atender às metas históricas de crescimento dos ganhos por ações, é provocativa, se constituindo numa interpretação questionável, porque os gestores estão assumindo ser extremamente míopes. Também que os resultados são inconsistentes com a hipótese de pesquisa por produzir resultados que resultam em explicações completamente alternativas, ainda que questões não relacionadas ao gerenciamento de resultados não foram consideradas.

Nagar, Nanda e Wysicki (2003) examinaram a relação entre a divulgação das atividades dos gestores e seus incentivos baseados em ações nos Estados Unidos. Os autores encontraram evidências de que as divulgações das empresas, medidas pelo gerenciamento de resultados e pela previsão de ganhos de analistas que avaliam as subjetivas práticas de divulgação, estão positivamente relacionadas com a proporção da remuneração do CEO afetada pelo preço das ações e pelo valor das ações detidas pelo CEO.

Bartov e Mohanram (2004) investigaram a decisão, por parte de executivos dos Estados Unidos de alto nível, de mais de 1.200 empresas, para exercer um grande número de prêmios de opção de ações, no período 1992-2001. Os resultados demonstraram que o desempenho anormalmente positivo dos lucros no período pré-exercício se transforma em desempenho de lucros decepcionantes no período pósexercício, e que esse padrão vem com uma surpresa até mesmo para os participantes do mercado sofisticado, ou seja, para os analistas financeiros. Assim, as descobertas sugerem que a informação privada, usada por executivos de alto nível para exercícios anormalmente grandes, decorre de gerenciamento de resultados, de modo a aumentar o pagamento em dinheiro dos exercícios.

Cheng e Warfield (2005) examinaram a ligação entre incentivos dos gestores de capital decorrentes da remuneração baseada em ações, a propriedade de ações e o gerenciamento de resultados, usando a remuneração baseada em ações e os dados de compra de ações ao longo do período 1993-2000, em empresas canadenses. A hipótese do estudo comprovada foi de que os gestores com incentivos altos são mais propensos a vender ações no futuro e isso os motiva a envolver-se em gerenciamento de resultados para aumentar o valor das ações a serem vendidas. Também foi comprovado, pela pesquisa de Cheng e Warfield 
(2005), que os gestores com incentivos patrimoniais consistentemente altos são menos propensos a relatar grandes surpresas por ganhos positivos, ou seja, confirma a prática consistente com income smoothing. Este achado é consistente com a riqueza do agente ser mais sensível para o desempenho das ações futuras, o que leva a um aumento da reserva de lucros correntes para evitar desapontamentos em ganhos futuros, amenizando a variabilidade dos resultados. De modo geral, os resultados indicam que os incentivos do agente o motivam à prática de gerenciamento de resultados.

Coles, Hertzel e Kalpathy (2006) investigaram o comportamento do mercado estadunidense em um cenário em que os incentivos para manipular os resultados e o preço de mercado das ações podem aparecer ex-ante para os participantes do mercado. Os autores encontraram evidências de accruals discricionárias anormalmente baixas no período seguinte aos anúncios de cancelamentos de opções de ações de executivos até o momento em que as opções são reeditadas. Embora analistas e investidores não estejam enganados, accruals discricionárias têm pouco poder para explicar o desempenho dos preços das ações durante este período. Além disso, accruals discricionárias não explicam os erros de previsão subsequentes dos analistas.

Comprix e Muller (2006) identificaram evidências de que a remuneração em dinheiro do CEO estadunidense é relativamente menos sensível a custos com pensões do que com a renda de pensão, o que sugere que os comitês de remuneração protejam a remuneração em dinheiro do CEO do montante das despesas de pensões. Também obtiveram evidências de que os gestores usam uma taxa esperada relativamente maior das estimativas de retorno ao relatar rendimentos de pensões, o que sugere que os gestores preferem aumentar as estimativas contábeis de renda em resposta à ênfase maior dos comitês de remuneração sobre os rendimentos de pensões nas determinações da remuneração em dinheiro do CEO.

Hunton, Mauldin e Wheeler (2008) demonstraram, em sua pesquisa nos Estados Unidos, que o monitoramento contínuo e o horizonte temporal sobre o qual os incentivos de desempenho são baseados podem interagir, gerando assim potenciais efeitos funcionais e disfuncionais nas decisões gerenciais. Observaram também, que a monitoração mais frequente diminuiu significativamente a vontade dos gestores de continuar com um projeto arriscado, mas viável, independentemente do horizonte temporal dos incentivos, e o efeito foi significativo no curto prazo. Com relação ao longo prazo, o efeito foi 
significativo para comportamentos disfuncionais e para planos de incentivos de longo prazo.

Mcanally, Srivastava e Weaver (2008), pesquisadores da Universidade do Texas, nos Estados Unidos, examinaram se a opção de ações possibilita explicar: a) redução de lucros alvos, incluindo as reduções divulgadas; b) redução de lucros reais; e c) a redução nas previsões de analistas. $\mathrm{O}$ estudo explora se a concessão de opções para os executivos incentiva a redução nas metas de lucros. Os resultados apontam que as empresas que reduzem metas de lucros têm maiores e mais valiosas doações subsequentes e que a probabilidade de redução em lucros alvos para as empresas que conseguem reduzir lucros com opções de subvenções de ações é maior. O estudo dos autores é o primeiro a descobrir que alguns gestores podem buscar o não alcance dos lucros alvos.

Carter, Lynch e Zechman (2009), pesquisadores americanos, examinaram e encontraram apoio para a hipótese conjunta de que a implementação da Lei Sarbanes-Oxley e de reformas relacionadas levaram a uma diminuição no gerenciamento de resultados e que as empresas reagiram, colocando mais peso sobre os lucros em contratos de bônus. Os autores não encontraram nenhuma evidência de que as empresas mudaram os planos de remuneração de executivos para assumir mais riscos.

Kalyta (2009) investigou em dados primários sobre CEOs estadunidenses aposentados de empresas listadas na Fortune 1000, o impacto dos planos de pensão do CEO em accruals discricionárias. $\mathrm{O}$ autor encontrou evidências de que as escolhas contábeis de renda crescente, no final de ano pré-reforma são particularmente atraentes para os gestores cuja pensão depende do desempenho da empresa nestes anos.

Laux e Laux (2009) analisaram as estratégias de equilíbrio do conselho de diretores para definir o pagamento de incentivos ao CEO e a supervisão da informação financeira e seus efeitos sobre o nível de gerenciamento de resultados. O primeiro autor é pesquisador germânico e o segundo americano e a amostra, objeto do estudo, compreende empresas americanas. Os autores demonstraram que um aumento equilibrado nos incentivos do CEO não, necessariamente, aumenta o gerenciamento de resultados, porque os diretores ajustam o seu esforço de supervisão em resposta a uma mudança nos incentivos do CEO, neste caso utilizando parte da remuneração baseada em ações. O modelo desenvolvido gera previsões relativas à estrutura das comissões dos conselhos com a sensibilidade de pagar a remuneração do CEO por 
desempenho, a qualidade da supervisão da diretoria e o nível de gerenciamento de resultados.

Diante da seleção de 20 pesquisas dentre as 288 encontradas, nota-se que o tema é amplamente disseminado na academia, em âmbito internacional. As contribuições dos diversos autores mencionados para os temas de remuneração dos executivos e de gerenciamento de resultados se ancoram, principalmente, na remuneração baseada em ações, na remuneração em dinheiro e na mensuração de desempenho do agente.

A seguir aborda-se o posicionamento teórico, que compreende os modelos e classificações que possibilitaram a operacionalização dos objetivos da pesquisa para a política de remuneração dos executivos e para o gerenciamento de resultados, por meio de atividades operacionais e accruals.

\subsection{POSICIONAMENTO TEÓRICO}

No posicionamento teórico apontam-se os modelos de mensuração utilizados no desenvolvimento do estudo, no sentido de alcançar os objetivos geral e específicos estabelecidos.

\subsubsection{Remuneração de Executivos}

Para a mensuração da política de remuneração do executivo, nesta pesquisa utilizou-se a proposição de Murphy (1999), que a subdivide nas perspectivas de nível e estrutura.

O nível corresponde ao valor da remuneração, mensurado em moeda corrente de cada país. Este modo de mensuração do valor da remuneração foi utilizado por Lambert e Larcker (1987), Jensen e Murphy (1990), Smith Jr. e Watss (1992), Gaver e Gaver (1993), Gaver e Gaver (1998), Murphy (1999), Jensen e Murphy (2004) e Murphy e Sandino (2010).

A estrutura se detém na segregação da remuneração em: salário, bônus anual, opções de ações, planos de incentivos de longo prazo e planos de benefícios de empregados. Esta estrutura tem sido utilizada por Jensen e Murphy (1990), Murphy (1999), Jensen e Murphy (2004) e Murphy e Sandino (2010).

A escolha pela proposição de Murphy (1999) se deve ao fato de que a remuneração possui diferentes composições em cada país e a proposição estabelecida pelo autor é genérica, ao desconsiderar a legislação trabalhista específica de cada país. A proposição foi aplicada 
a uma pesquisa que abrangeu 23 países. Também por proporcionar comparabilidade nos resultados encontrados por esta pesquisa com os resultados da pesquisa de Murphy (1999), em vista da característica apontada.

\subsubsection{Gerenciamento de Resultados}

Esta pesquisa utilizou-se de diferentes modelos para a mensuração da proxy de gerenciamento de resultados por meio de atividades operacionais e por meio de accruals.

Para estimar os níveis normais de gerenciamento de resultados por meio de atividades operacionais foram utilizados os modelos de Anderson, Banker e Janakiraman (2003), de Gunny (2005) e de Roychowdhury (2005). A pesquisa se concentrou em três métodos de manipulação e seus efeitos, utilizando: o primeiro modelo para as despesas com vendas, gerais e administrativas; o segundo para despesas com pesquisa e desenvolvimento, ambos com o intuito de identificar redução de despesas discricionárias; e o último para os níveis de produção, com o intuito de identificar superprodução, ou seja, aumento dos níveis de produção gerando menor custo do produto vendido.

A escolha destes modelos se deve: a) para o modelo de Anderson, Banker e Janakiraman (2003), ao fato de não haver previsão na literatura até o momento de outro modelo para estimação de gerenciamento de resultados por despesas com vendas, gerais e administrativas; b) para o modelo de Gunny (2005), por entender que o mesmo é adequado para empresas industriais, objeto de estudo nesta pesquisa, pelo fato dessas empresas, ao desenvolverem seus novos produtos ou aperfeiçoar os já existentes, possuírem relevantes investimentos em pesquisa e desenvolvimento; e c) para o modelo de Roychowdhury (2005), por motivo semelhante ao item 'b', pois a estimação dos níveis de produção ocorre em empresas industriais. Estes modelos também têm sido utilizados por Gunny (2005), Roychowdhury (2005) e Cardoso e Martinez (2006).

Para estimar os níveis normais de gerenciamento de resultados por meio de accruals discricionárias foi utilizado o modelo de Dechow, Sloan e Sweeney (1995). A escolha deste modelo se deve ao fato deste ser o mais utilizado, em termos de quantidade de aplicações, em pesquisas científicas divulgadas em periódicos internacionais de contabilidade de alto impacto. Esse fato foi comprovado pela pesquisa bibliométrica realizada em estudos preliminares sobre o gerenciamento 
de resultados desta tese, bem como na pesquisa realizada por Machado, Benetti e Bezerra (2011).

Os modelos citados são descritos em equações, apresentando suas variáveis e subvariáveis, bem como os períodos necessários para a estimação dos valores pretendidos, no constructo da pesquisa, incluído no capítulo três desta tese, relativo ao método e as técnicas de pesquisa utilizadas para a solução do problema empírico proposto.

Neste capítulo do trabalho apresentou-se a trajetória epistemológica, que situou a pesquisa no campo epistêmico; a revisão de literatura, que situou a pesquisa no campo teórico; e o posicionamento teórico, que situou a pesquisa dentre os diversos modelos existentes na literatura, definindo os que foram utilizados, por quem foram utilizados e quais os motivos da escolha destes para operacionalização desta pesquisa. No capítulo que segue descrevem-se o método e os procedimentos da pesquisa. 


\section{MÉTODO E PROCEDIMENTOS DA PESQUISA}

Conforme Bruyne, Herman e Shouteete (1977, p. 27), "o conhecimento científico só merece este nome se foi elaborado segundo as regras da metodologia científica". Assim, buscou-se delinear esta pesquisa de forma a seguir a indicação dos autores. "A metodologia é a lógica dos procedimentos científicos em sua gênese e em seu desenvolvimento, não se reduz, portanto a uma 'metrologia' ou tecnologia da medida dos fatos científicos" (BRUYNE; HERMAN; SHOUTEETE, 1977, p. 29).

De acordo com os autores, o foco principal deve ser o produto da metodologia, que é o resultado em forma de conhecimento científico, também o processo, como gênese desse próprio conhecimento. Tendo o dever de explicar não apenas o produto da investigação científica, mas principalmente seu processo, descrito com os passos dados até a descoberta. "Os princípios da pesquisa científica não devem derivar de fora da prática metodológica, sendo ela própria concebida em sentido amplo como reflexão crítica sobre as dimensões concretas da pesquisa" (BRUYNE; HERMAN; SHOUTEETE, 1977, p. 29-30).

\subsection{ESTRATÉGIA METODOLÓGICA}

Bruyne, Herman e Shouteete (1977) definem do ponto de vista metodológico, uma articulação de diferentes instâncias, de diferentes polos e os organizam em um espaço metodológico quadripolar, com quatro polos distintos, são eles: o polo epistemológico, o polo teórico, o polo morfológico e o polo técnico. Estes são complementados por: métodos, quadros de análises, quadros de referências e modos de investigação.

O polo epistemológico encarrega-se de renovar continuamente a ruptura dos objetos científicos com os do senso comum, explicita as regras de produção, de explicação dos fatos, da compreensão e validade das teorias, exercendo a função de vigilância crítica e utilizando-se de métodos para a sua efetivação. Já o polo teórico guia a elaboração das hipóteses e a construção dos conceitos, embasando a construção sistemática do conhecimento científico, propõe regras de interpretação dos fatos, de especificação e definição das soluções encontradas às problemáticas de pesquisa e utiliza-se dos quadros de referências para efetivar suas contribuições teóricas (BRUYNE; HERMAN; SHOUTEETE, 1977). 
O polo morfológico enuncia as regras de estruturação, de formatação do objeto científico, impondo ordem entre seus elementos, suscitando diversas modalidades de quadros de análise e diversos métodos de ordenação dos elementos constitutivos dos objetos científicos. O polo técnico controla a coleta de dados, esforçando-se para constatá-los para poder confrontá-los com a teoria que os suscitou, utilizando-se de diversos modos de investigação (BRUYNE; HERMAN; SHOUTEETE, 1977).

Na Figura 10 apresenta-se uma ilustração gráfica do posicionamento metodológico elaborado pelos autores.

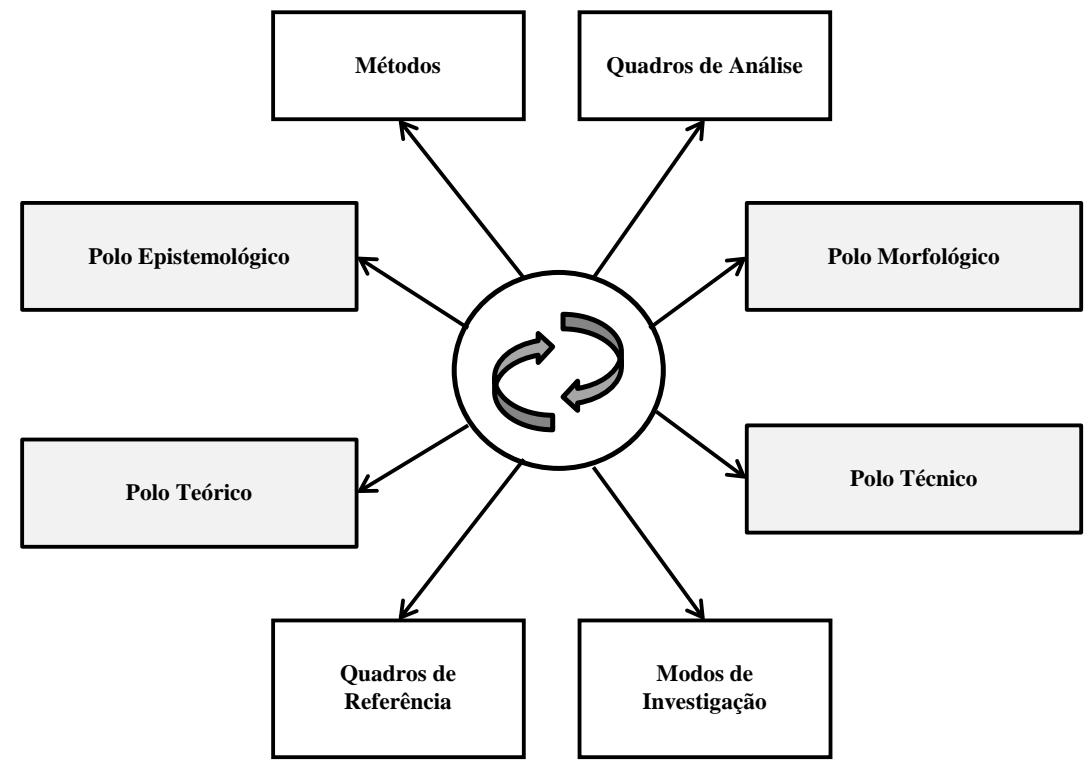

Figura 10 - Espaço metodológico quadripolar

Fonte: Elaborado a partir de Bruyne, Herman e Shouteete (1977, p. 36).

Utilizando-se da Figura 10 para descrever as escolhas metodológicas desta tese, declara-se que o polo epistemológico utilizou o método quantitativo para garantir a objetividade dos resultados esperados. $\mathrm{O}$ polo teórico utilizou o quadro de referência funcionalista para guiar a construção conceitual da pesquisa.

O polo morfológico utilizou-se do quadro sistêmico de análise para ordenar os elementos constitutivos dos objetivos científicos. De acordo com Bruyne, Herman e Shouteete (1977, p. 183), este "reconhece numa problemática qualquer de pesquisa a predominância 
do todo sobre as partes e, por conseguinte, aborda seu objeto sobre a forma coerente e globalizante de uma rede de relações". Por fim, o polo técnico utilizou-se de estudos comparativos como modo de investigação.

Conforme Richardson (1989, p. 29), "método significa a escolha de procedimentos sistemáticos para a descrição e explicação de fenômenos". Assim, no âmbito do método científico busca-se delinear a pesquisa desenvolvida neste trabalho.

\subsection{DELINEAMENTO DA PESQUISA}

Segundo Cervo e Bervian (2002, p. 63), a pesquisa científica “é uma atividade voltada para a solução de problemas teóricos ou práticos com o emprego de processos científicos". O delineamento da pesquisa busca esclarecer os procedimentos científicos adotados, pois, conforme os autores, cada tipo de pesquisa possui um núcleo comum de procedimentos, como também peculiaridades próprias. Para explicar os procedimentos científicos seguidos nesta pesquisa adotaram-se critérios de sistematização, descritos a seguir.

Do ponto de vista dos objetivos esta pesquisa se classifica como descritiva. Para Cervo e Bervian (2002, p. 66), "a pesquisa descritiva observa, registra, analisa e correlaciona fatos ou fenômenos (variáveis) sem manipulá-los". Conforme os autores, trata-se do estudo e da descrição das características, propriedades ou relações existentes na realidade pesquisada. Oliveira (2002, p. 114) destaca que a pesquisa descritiva se constitui em um "tipo de estudo que permite ao pesquisador a obtenção de uma melhor compreensão do comportamento de diversos fatores e elementos que influenciam determinado fenômeno".

Gil (2002, p. 42) explica que "as pesquisas descritivas têm como objetivo primordial a descrição das características de determinada população ou fenômeno ou, então, o estabelecimento de relações entre as variáveis". Este estudo se caracteriza como descritivo por descrever características das empresas industriais relativas à remuneração de seus executivos e suas informações contábeis, baseando-se no registro, análise e correlação das observações coletadas.

Com relação aos procedimentos, ou seja, a forma como os dados foram coletados, esta pesquisa se classifica como documental. Conforme Cervo e Bervian (2002), na pesquisa documental são investigados documentos a fim de se poder descrever e comparar tendências, diferenças e outras características estudadas. 
Gil (2002, p. 45) destaca que a pesquisa documental "vale-se de materiais que não receberam ainda um tratamento analítico, ou que ainda podem ser reelaborados de acordo com os objetivos da pesquisa". Este estudo se classifica como documental por utilizar na coleta dos dados relatórios de evidenciação da remuneração dos executivos e demonstrações econômico-financeiras das empresas objeto do estudo. Estes se constituem em fontes secundárias de dados, mas que ainda não receberam tratamento analítico no contexto dos objetivos desta pesquisa.

Quanto à forma de abordagem do problema, esta pesquisa se classifica como quantitativa. Conforme Oliveira (2002), a pesquisa de abordagem quantitativa é muito utilizada no desenvolvimento de pesquisas descritivas.

Entre os diferentes modos de raciocínio que permitem guiar a pesquisa e expor rigorosamente seus resultados, a quantificação participou das ciências sociais de modo considerável. Ela intervém, algumas vezes, de uma maneira alusiva e esporádica na pesquisa para consolidar uma argumentação dando-lhe precisão e, por conseguinte, um peso suplementar. Mas em sentido amplo, constitui uma ligação entre a operacionalização das hipóteses e a coleta das informações, submete nesse caso o conjunto da pesquisa às suas exigências metodológicas. Ela impõe uma ordem ao universo de números, autorizando, então, a comparabilidade numérica e a aplicação de métodos de tratamento quantitativos (BRUYNE; HERMAN; SHOUTEETE, 1977). Assim, este estudo se classifica como quantitativo devido a natureza do problema de pesquisa, a operacionalização das hipóteses e a coleta de dados.

\subsection{POPULAÇÃO E AMOSTRA}

Ao selecionar a população e amostra deste estudo optou-se por segrega-las em quatro partes: a primeira relativa às pessoas objeto do estudo; a segunda relativa às empresas; a terceira relativa ao período compreendido; e a quarta relativa aos países estudados.

\subsubsection{Pessoas}

Dentre a população de pessoas existentes na empresa, optou-se nesta pesquisa pelo agente organizacional que é o CEO ou executivo presidente. Segundo Dechow, Huson e Sloan (1994), o CEO tem a responsabilidade geral pelo desempenho da empresa e, portanto, 
susceptível de desempenhar um papel fundamental na decisão de reestruturar as operações da empresa.

Destaca-se que relativo ao CEO à frente da organização, foram coletados os dados do executivo presidente, sendo um por empresa, para analisar a relação das características de idade, gênero e expertise com a remuneração dos executivos e o gerenciamento de resultados por meio de atividades operacionais e accruals discricionárias. Sobre a remuneração dos executivos foram coletados os valores e a estrutura da remuneração de toda a diretoria executiva.

A escolha pelo CEO, assim como na pesquisa de Dechow, Huson e Sloan (1994), facilita a comparação dos resultados com pesquisas existentes, também pelo envolvimento do mesmo no processo decisório da organização.

O período de pesquisa compreendeu, para os dados relativos aos executivos, os exercícios de 2007 a 2010, abrangendo 4 anos.

\subsubsection{Empresas}

Do universo de empresas, a amostra não probabilística escolhida para objeto de estudo foi das empresas industriais com ações negociadas em bolsas de valores. A necessidade das empresas possuírem ações negociadas em bolsa de valores se deve ao fato de que, estas têm o relatório de remuneração de seus administradores disponibilizados publicamente.

$\mathrm{O}$ fato de serem empresas industriais possibilita a investigação de gestão de atividades operacionais atreladas à pesquisa e desenvolvimento de novos produtos e aos níveis de produção.

O período de pesquisa compreendeu, para os dados relativos às informações contábeis das empresas, os exercícios de 2006 a 2010, envolvendo 5 anos.

As empresas que não possuíam valores para todas as variáveis necessárias foram excluídas da amostra. Os dados relativos aos executivos são das mesmas empresas dos dados contábeis.

\subsubsection{Países}

Os países selecionados para esta pesquisa foram o Brasil (BRA), os Estados Unidos da América (EUA) e a Inglaterra (ING). A seguir estão arroladas algumas considerações que motivaram a escolha destes países. 
a) Estados Unidos da América (EUA)

Sobre a disseminação do tema da remuneração do executivo, de acordo com Murphy (1999), poucos assuntos na história da corporação moderna têm atraído tanta atenção como a remuneração de executivos em empresas dos Estados Unidos. Além disso, tonou-se uma questão internacional debatida em congressos e rotineiramente destaque em manchetes de primeira página, matérias de capa e noticiários de televisão.

Este destaque alcança surveys realizadas e disponibilizadas pela Forbes (2009); pela Standard \& Poor's ExecuComp - S\&P 500; pelo Wall Street Journal (2009); pela base de dados COMPUSTAT ExecuComp, que em setembro de 2011 possuía em seus arquivos 3.000 empresas (COMPUSTAT, 2011). Pesquisas como a de Sloan (1993) já utilizavam a base de dados da Forbes. Quanto à ExecuComp são inúmeras as pesquisas internacionais que a utilizam. Brookman, Jandik e Rennie (2006) declaram que a ExecuComp da COMPUSTAT, a Standard \& Poor's Execucomp, a Forbes Annual Compensation Survey e a The Wall Street Journal Compensation Survey CEO são as bases mais utilizadas nas pesquisas americanas para este tema.

Quanto às normas de evidenciação da remuneração dos executivos. Conforme as normas da SEC, nos EUA já há uma regulamentação desde 1938, possibilitando com os dados publicados a realização de pesquisas científicas, como a de Murphy (1999), que demonstra que os níveis de sensibilidade da remuneração entre a estrutura de pagamento e desempenho são mais elevados nos EUA do que em outros países.

Vários fatores têm contribuído para o interesse generalizado na remuneração dos executivos nos EUA, tais como: a) a ascensão da remuneração do CEO, desde 1970, pois a remuneração paga em dinheiro mais que duplicou e a remuneração total quase quadruplicou; b) os 'excessos da década de 1980', associados à percepção de que o CEO de salários altos estavam atrelados a demissões, fechamento de fábricas, e downsizing corporativo; e c) o mercado de ações da década de 1990, cujo pagamento dos CEOs tornou-se cada vez mais ligado ao desempenho do preço das ações da empresa (MURPHY, 1999).

Sobre o mercado acionário, os EUA, conforme Chen (2003), é o país onde é mais difundido o conceito da remuneração por opções de ações, um dos motivos para isso está refletido na pulverização do capital nestes mercados. Nos EUA está concentrado o maior mercado de ações do mundo, operado, inclusive, por pequenos investidores, que nele 
depositam em grande proporção suas poupanças individuais (CHEN, 2003).

Com relação a pesquisas científicas realizadas nos EUA, Souza e Borba (2007) declaram que o continente americano apresentou aproximadamente $67 \%$ dos artigos empíricos da amostra de seu estudo, principalmente em razão da grande publicação por parte dos Estados Unidos, visto que desses $67 \%$ de artigos, 93,3\% tinham como origem este país.

b) Brasil (BRA)

No Brasil, a implantação dos planos de remuneração com base em opções de ações data da década de 70, influenciada pelas empresas norte-americanas instaladas no País, que importaram a mesma metodologia de remuneração para os executivos locados no Brasil (NUNES; MARQUES, 2005).

O Brasil passou a evidenciar as informações da remuneração de seus executivos recentemente. Considera-se estar em estágio inicial do processo de evidenciação, dado que a IN $n^{\circ} 480$ da CVM entrou em vigor no exercício de 2010, solicitando a evidenciação dos três últimos exercícios e do exercício corrente, o que possibilita a realização de pesquisas com estas informações disponibilizadas publicamente a partir do ano de 2007.

Observa-se uma escassez de pesquisas científicas sobre o tema divulgadas em periódicos brasileiros de contabilidade, haja vista que desde a primeira edição destes periódicos, classificados pelo Webqualis da CAPES, nos estratos A2, B1, e B2, até março de 2012 foram encontrados apenas 8 artigos publicados sobre a remuneração de executivos, descritos nos estudos anteriores publicados em periódicos nacionais, no item 2.2.2.4 desta tese.

c) Inglaterra (ING)

$\mathrm{Na}$ Inglaterra, reformas de governança corporativa ocorreram no início dos anos 1990. Especialmente as instituídas pelos relatórios Cadbury (1992) e Greenbury (1995), que promoveram uma redução da remuneração dos executivos. A criação e dominação de comitês por diretores não executivos, ou seja, empregados de tempos parciais acabaram por limitar a remuneração com padrões comparativos de tamanho da empresa (HAYNES; THOMPSON; WRIGHT, 2007; MURPHY; SANDINO, 2010). 
Por outro lado, a evidenciação da remuneração de executivos da Inglaterra, ou seja, do Reino Unido como um todo, por meio do Greenbury (1995), passou a possibilitar a ampliação de pesquisas científicas sobre a temática. Pesquisas surgiram a partir desta evidenciação, como a de Haynes, Thompson e Wright (2007) sobre desinvestimento corporativo e remuneração de executivos, discorrendo sobre um framework conceitual comparativo entre EUA e UK, identificando semelhanças entre práticas destes países.

Conforme Jobome (2006), a relação entre a remuneração de executivos e o desempenho da empresa é um problema muito estudado empiricamente na literatura de governança corporativa, em organizações dos EUA. Para o Reino Unido, no entanto, tais provas permanecem escassas para preencher esta lacuna. A partir da pesquisa do autor, surgiu a pesquisa realizada por Ozkan (2007) sobre a sensibilidade da estrutura de remuneração por desempenho e dos mecanismos de governança corporativa, realizada com empresas do Reino Unido, que demonstrou que a presença de acionistas institucionais interfere positivamente e negativamente na sensibilidade desta relação.

Pesquisa realizada por Ederhof (2011) confirma a semelhança entre planos de remuneração para gestores de nível médio entre UK e EUA. Iqbal e Strong (2010) encontraram evidências de que as empresas do Reino Unido, semelhante as dos EUA, têm incentivos para gerenciar ganhos em torno da oferta de ações secundárias.

Economicamente, na pesquisa de Murphy (1999), UK e EUA estiveram entre as cinco primeiras nações que mais remuneram seus executivos. Também, segundo Pownall (1993), estes países estiveram entre os quatro que possuíam somados mais de $95 \%$ da capitalização do mercado acionário mundial. Pesquisa realizada por Land e Lang (2002) demonstrou que empresas do UK se mantiveram em primeiro lugar de 1987 até 2002 com maior retorno sobre o patrimônio líquido do que a de outros países.

As pesquisas sobre gerenciamento de resultados com empresas da Inglaterra são escassas. O estudo de Peasnell, Pope e Young (2005) evidenciou que empresas do Reino Unido com um maior percentual de diretores não executivos no conselho de administração são relacionadas à menor gerenciamento de resultados para aumentar as receitas. Ball e Shivakumar (2005) pesquisaram a oportunidade de reconhecimento de perdas comparativas no âmbito da qualidade do gerenciamento de resultados em empresas privadas do UK. Os resultados aprimoram a compreensão de empresas públicas e privadas desta nação, especialmente as privadas que são predominantes na economia. 
Também forneceram insights sobre reflexos da economia nas normas contábeis.

d) Os três países

Murphy (1999), em sua pesquisa sobre a remuneração de executivos de 23 países, teve em sua amostra executivos brasileiros, estadunidenses e ingleses. Lang, Raedy e Wilson (2006) realizaram pesquisa em 488 empresas dos EUA e 181 empresas de outros 34 países, sendo dessas últimas 42 da Inglaterra e uma do Brasil. Ressaltam-se que, embora as características dos dados contábeis sejam potencialmente distintas, pesquisas com empresas de países diferentes podem fornecer insights sobre diferenças ou semelhanças internacionais em determinado tema.

Klann (2011) investigou a influência do processo de convergência às normas contábeis internacionais do IASB, no nível de gerenciamento de resultados de 721 empresas inglesas, e de 170 brasileiras. Os resultados mostram que após a adoção das IFRS pelas empresas inglesas, houve redução nos níveis de gerenciamento de resultados contábeis. Nas empresas brasileiras ocorreu o inverso, além de um maior impacto no gerenciamento de resultados com o processo de convergência, em relação às empresas inglesas. Denota-se que investigações empíricas tornam-se necessárias para ampliar o escopo científico do corpo de conhecimento existente.

O mercado dos EUA oferece configurações institucionais, estruturas de governança e ambientes de litígios, diferentes do Reino Unido. Desta forma, a generalidade das conclusões americanas é limitada (BASIRUDDIN, 2011). Assim, se torna relevante pesquisar outros países concomitantemente com os EUA, pois a generalidade dos resultados das pesquisas americanas, que são maioria em termos internacionais, tanto para o gerenciamento de resultados, quanto para a remuneração de executivos, é limitada para outros países.

Dadas as diferenças internacionais citadas nos estudos realizados anteriormente a esta pesquisa, em termos de configurações institucionais, regulamentações, estruturas de governança, pulverização do capital, contingências, entre o Brasil, os Estados Unidos da América e a Inglaterra, e utilizando-se do raciocínio lógico-dedutivo, pode-se esperar que países que não são comparáveis entre si, ao serem pesquisados conjuntamente demonstrem resultados empíricos distintos, mas que só é verificável por meio de pesquisa. 
A motivação para a realização da pesquisa com o Brasil, Estados Unidos da América e Inglaterra, decorre da relevância da remuneração dos executivos, do tempo de evidenciação desta e da investigação empírica necessária para a contribuição da ciência. Além desses aspectos, citam-se: a) o alto nível de remuneração dos executivos nos EUA; b) a forte influência econômica da Inglaterra sobre os demais países; c) a semelhança da Inglaterra, em termos de planos de remuneração com os EUA; d) o estágio embrionário de desenvolvimento de pesquisas sobre remuneração de executivos tanto para o Brasil quanto para a Inglaterra; e) a influência que os EUA tiveram no plano de remuneração de executivos brasileiros; f) o início do processo de evidenciação destes planos pelo Brasil; g) a escassez de pesquisas científicas sobre o tema no Brasil e na Inglaterra.

\subsubsection{Amostra de empresas}

Ao verificar o cadastro de cada empresa, na CVM para as brasileiras, na SEC para as estadunidenses e nos portais eletrônicos para as inglesas, conforme redirecionamento do portal da London Stock Exchange (LSE), foi constatado que a atividade principal de algumas empresas apresentava divergência com o registro da Thomson e da Economática. Desta forma, optou-se por seguir a classificação de atividade da CVM, da SEC e das empresas inglesas conforme suas divulgações nas demonstrações financeiras no subitem business. A amostra deste estudo esta descrita na Tabela 1.

Tabela 1 - Amostra de empresas

\begin{tabular}{|c|c|c|c|c|c|c|c|}
\hline Amostra / País & BRA & EUA & ING & Total & $\begin{array}{c}\% \\
\text { BRA }\end{array}$ & $\begin{array}{c}\% \\
\text { EUA }\end{array}$ & $\begin{array}{c}\% \\
\text { ING }\end{array}$ \\
\hline Amostra inicial & 425 & 548 & 122 & 1.095 & 38,8 & 50,0 & 11,1 \\
\hline Empresas comerciais & -30 & -25 & -7 & -62 & 48,4 & 40,3 & 11,3 \\
\hline $\begin{array}{l}\text { Empresas de utilidades e } \\
\text { serviços }\end{array}$ & -184 & -157 & -40 & -381 & 48,3 & 41,2 & 10,5 \\
\hline Holdings & -18 & -4 & -5 & -27 & 66,7 & 14,8 & 18,5 \\
\hline Empresas sem & 0 & -39 & 0 & -39 & 0,0 & 100,0 & 0,0 \\
\hline Empresas sem info & -163 & 0 & 0 & -163 & 100,0 & 0,0 & 0,0 \\
\hline $\begin{array}{l}\text { Empresas } \\
\text { seus porta }\end{array}$ & 0 & 0 & -23 & -23 & 0,0 & 0,0 & 100,0 \\
\hline Amostra final & 30 & 323 & 47 & 400 & 7,5 & 80,8 & 11,8 \\
\hline
\end{tabular}

Fonte: Dados da pesquisa. 
Observa-se na Tabela 1 que a amostra inicial do estudo compreendia 1.095 empresas, sendo 425 do Brasil, 548 dos Estados Unidos da América e 122 da Inglaterra. As empresas estadunidenses e inglesas foram extraídas da base de dados contábeis da Thomson One Banker para o código Standard Industrial Classification (SIC) 2000, que corresponde à atividade industrial, em novembro de 2011. As empresas brasileiras foram extraídas da base de dados contábeis da Economática, especificamente as com registro na CVM e classe de ações Ordinárias Nominativas (ON), em janeiro de 2012.

Após a revisão da atividade preponderante, da amostra inicial de 1.095 empresas excluíram-se as empresas que não possuem a industrialização como atividade principal, que é o objeto deste estudo, ou que não apresentaram as informações relativas à remuneração de seus executivos no período de 2007 a 2010 e, simultaneamente, os dados contábeis no período de 2005 a 2010. Assim, foram excluídas 695 empresas, restando 400, que foram objeto de análise deste estudo.

Destaca-se que a atividade desenvolvida pelas empresas prestadoras de serviços e utilidades foi representativa na exclusão, correspondendo a 381 empresas, do total de 1.095. A amostra final de 400 empresas industriais constitui-se de 7,5\% brasileiras, $80,8 \%$ estadunidenses e $11,8 \%$ inglesas.

A amostra final deste estudo é representativa para as empresas industriais estadunidenses, pois do total de 362 indústrias, 323 compuseram a amostra analisada, que representa, aproximadamente, $89 \%$ do total. Para as empresas industriais inglesas, de forma semelhante as estadunidenses, em termos de representatividade, do total de 70 indústrias, 47 fizeram parte da amostra estudada, o que representa cerca de $67 \%$ do total. Por outro lado, para as empresas industriais brasileiras, do total de 193 indústrias, apenas 30 foram analisadas, dado que em torno de $84 \%$ do total de indústrias não possuía dados evidenciados relativos a remuneração de executivos, no período compreendido nesta pesquisa.

Cabe ressaltar que o tratamento quantitativo realizado na análise dos dados desta pesquisa, por meio dos testes estatísticos, teve caráter ilustrativo, dada a aplicação na amostra não probabilística. Desta forma, os resultados encontrados não representam e não podem ser generalizados para a população, sendo restritos apenas a amostra analisada. Nos Quadros 10, 11 e 12 listam-se as empresas da amostra final. 


\begin{tabular}{|l|l|}
\hline \multicolumn{2}{|c|}{ Razão Social } \\
\hline Alpargatas S.A. & Inepar S.A. Ind. e Construções \\
\hline Baumer S.A. & Karsten S.A. \\
\hline BRF - Brasil Foods S.A. & Lupatech S.A. \\
\hline Cia Hering & Marfrig Alimentos S.A. \\
\hline Cia Indl Schlosser S.A. & Metalgráfica Iguaçu S.A. \\
\hline Cia. Iguaçu de Café Solúvel & Metisa Metalúrgica Timboense S.A. \\
\hline Companhia Industrial Cataguases & Panatlântica S.A. \\
\hline Companhia Providencia Ind. e Com & Portobello S.A. \\
\hline Dohler S.A. & Pró Metalurgia S.A. \\
\hline Electro Aço Altona S.A. & Schulz S.A. \\
\hline Eucatex S.A. Ind. e Comercio & Siderúrgica J L Aliperti S.A. \\
\hline Fab Tecidos Carlos Renaux S.A. & Souza Cruz S.A. \\
\hline Fibam Cia Industrial & Springer S.A. \\
\hline Forjas Taurus S.A. & Vicunha Têxtil S.A. \\
\hline Haga S.A. Indústria e Comércio & Wetzel S.A. \\
\hline
\end{tabular}

\section{Quadro 10 - Amostra de empresas brasileiras}

Fonte: Dados da pesquisa.

No Quadro 10 constam as 30 empresas que representam, na amostra, as empresas industriais brasileiras cadastradas na Economática que evidenciaram todas as informações, do período analisado neste estudo. Estas empresas atuam na atividade fabril nos segmentos de: alimentos, bebidas, eletroeletrônicos, minerais não metálicos, papel, celulose, químico, siderurgia, metalurgia, têxtil, veículos, peças e outros. As mesmas possuem cadastro na CVM e ações negociadas na Bolsa de Valores Mercadorias e Futuros (BM\&FBovespa).

\begin{tabular}{|l|l|l|}
\hline \multicolumn{3}{|c|}{ Razão Social } \\
\hline 3M Company & Flowserve Corp. & Park Ohio Holdings Corp \\
\hline Aaon Inc & Franklin Electric Co Inc & Parker-Hannifin Corp \\
\hline AAR Corp & Freightcar America Inc & Pentair Inc \\
\hline Active Power Inc & Frequency Electron. Inc & Perceptron Inc \\
\hline Adept Technology Inc & Fuelcell Energy Inc & Perkinelmer Inc \\
\hline Advanced Photonix Inc & Gardner Denver Inc & PGT Inc \\
\hline AEP Industries Inc & Gencor Industries Inc & Photonic Prod Group Inc \\
\hline Aerovironment Inc & Gencorp Inc & Planar Systems Inc \\
\hline
\end{tabular}




\begin{tabular}{|c|c|c|}
\hline Agco Corporation & Gibraltar Industries Inc & Plexus Corp \\
\hline Agilent Technologies Inc & Giga-Tronics Inc & Pmfg Inc \\
\hline Alamo Group Incorp & Goodrich Corp & Powell Industries Inc \\
\hline Albany International Corp & Graco Inc & Power-One Inc \\
\hline Alliant Techsystems Inc & Graftech Internat Lted. & Powerwave Technol Inc \\
\hline Allied Motion Techno Inc & Graham Corp & Precision Castparts Corp \\
\hline Altra Holdings Inc & Graphic Packaging H Co & \begin{tabular}{|l|} 
Quanex Build. Prod Co \\
\end{tabular} \\
\hline American Biltrite Inc & Greatbatch Inc & Raven Industries Inc \\
\hline American Electric Tec Inc & Greif Inc & RBC Bearings Inc \\
\hline American Railcar Ind Inc & Griffon Corp & R F Industries Limited \\
\hline American Science \& Eng & Hardinge Inc & RF Monolithics Inc \\
\hline American Superc Corp & Harsco Corp & Robbins \& Myers Inc \\
\hline American Woodmark Corp & Heico Corp & Rock-Tenn Company \\
\hline Ametek Inc & Hexcel Corp & Rockwell Automat. Inc \\
\hline Amphenol Corp & Hickok Inc & Rockwell Collins Inc \\
\hline Anaren Inc & Honeywell Internat Inc & Rofin-Sinar Technol Inc \\
\hline Apogee Enterprises Inc & Hubbell Inc & \begin{tabular}{|l} 
Rubicon Technology Inc \\
\end{tabular} \\
\hline Aptargroup Inc & Hurco Companies Inc & Sanmina-SCI Corp \\
\hline Armstrong World Ind Inc & Idex Corp & Satcon Technology Corp \\
\hline Arotech Corp & IEH Corp & Schmitt Industries Inc \\
\hline Art's-Way Manuf Co Inc & II VI Inc & Sealed Air Corp \\
\hline Asia Cork Inc & Illinois Tool Works Inc & Servotronics Inc \\
\hline Astec Industries Inc & Image Sensing Syst Inc & \begin{tabular}{|l|} 
Sevcon Inc \\
\end{tabular} \\
\hline Astronics Corp & Insteel Industries Inc & Shaw Group Inc \\
\hline AVX Corp & International Baler Corp & Sierra Monitor Corp \\
\hline AZZ Inc & Intevac Inc & Sifco Industries Inc \\
\hline Badger Meter Inc & Intricon Corp & Sigmatron Internati Inc \\
\hline Baldwin Technol Co Inc & IPG Photonics Corp & Silgan Holdings Inc \\
\hline Ball Corp & Itron Inc & Simpson Manuf Co Inc \\
\hline Ballantyne Strong Inc & Jabil Circuit Inc & SL Industries Inc \\
\hline Barnes Group Inc & JOY Global Inc & Smith \& Wesson H Corp \\
\hline BE Aerospace Inc & Kaydon Corp & Smith A O Corp \\
\hline Beam Inc & Kemet Corp & Smith Midland Corp \\
\hline Bel Fuse Inc & Kennametal Inc & Smtc Corp \\
\hline Belden Inc & Key Technology Inc & Sono TEK Corp \\
\hline Bemis Company Inc & Keystone Consol Ind Inc & Sonoco Products Co \\
\hline Benchmark Electronics Inc & Landec Corp (De) & Spartan Motors Inc \\
\hline Black Box Corp & Lecroy Corp & Sparton Corp \\
\hline Blonder Tongue Labor Inc & Lennox International Inc & Spire Corp \\
\hline Brady Corp & LGL Group Inc (The) & Spirit Aerosystems H Inc \\
\hline Breeze-Eastern Corp & Lightpath Technolog Inc & SPX Corp \\
\hline BTU International Inc & Lime Energy Company & Strategic Diagnostics Inc \\
\hline Builders Firstsource Inc & Lincoln Elec. Hold Inc & Sturm Ruger \& Co Inc \\
\hline Butler National Corp & Lindsay Corporation & \begin{tabular}{|l} 
Sun Hydraulics Corp \\
\end{tabular} \\
\hline C \& D Technologies Inc & LMI Aerospace Inc & Supreme Industries Inc \\
\hline
\end{tabular}




\begin{tabular}{|l|l|l|} 
Capstone Turbine Corp & Louisiana Pacific Corp & Sutron Corp \\
\hline Carlisle Companies Inc & LSI Industries Inc & Sypris Solutions Inc \\
\hline Cascade Corp & Lydall Inc & Taser International Inc \\
\hline Caterpillar Inc & Magnetek Inc & Taylor Devices Inc \\
\hline Ceco Environmental Corp & Manitex International Inc & Tecumseh Products Co \\
\hline Cenveo Inc & Martin Marietta Mat Inc & Tel Instrument Elec Corp \\
\hline Ceradyne Inc & Masco Corp & Tennant Company \\
\hline Chart Industries Inc & Materion Corp & Terex Corp \\
\hline Checkpoint Systems Inc & Maxwell Technolog Inc & Texas Industries Inc \\
\hline Chicago Rivet \& Mach Co & Meadwestvaco Corp & Dewey Electronics Corp \\
\hline Clearfield Inc & Measurem. Specialt Inc & Gorman-Rupp Company \\
\hline Clearone Communic Inc & Mechanical Technol Inc & Greenbrier Co Inc \\
\hline Cognex Corp & Meritor Inc & Manitowoc Co Inc \\
\hline Coherent Inc & Mesa Laboratories Inc & Timken Company \\
\hline Coleman Cable Inc & MET-Pro Corp & Toro Company \\
\hline Colonial Commercial Corp & Metalico Inc & Thomas \& Betts Corp \\
\hline Columbus McKinnon Corp & Methode Electronics Inc & TII Network Technol Inc \\
\hline Comfort Systems USA Inc & Mettler Toledo Int Inc & Torotel Inc \\
\hline Commerc Vehicle G. Inc & Metwood Incorporated & Transcat Inc \\
\hline Continental Materials Corp & Mfri Inc & Transdigm Group Inc \\
\hline Courier Corp & Micronetics Inc & Trex Company Inc \\
\hline CPI Aerostructures Inc & Micropac Industries Inc & Trimas Corp \\
\hline CTS Corp & Microwave Filter Co Inc & Trimble Navig. Limited \\
\hline Cubic Corp & Mikros Systems Corp & Triumph Group Inc \\
\hline Cummins Inc & Miller Industries Inc & TTM Technologies Inc \\
\hline Curtiss Wright Corp & Mine Safety Appl. Co & Twin Disc Inc \\
\hline CVD Equipment Corp & Mocon Inc & UFP Technologies Inc \\
\hline Cyberoptics Corp & MOD-PAC Corp & Ultralife Corp \\
\hline Daktronics Inc & Molex Inc & United Technol Corp \\
\hline DDI Corp & Monarch Cement Co & Universal Display Corp \\
\hline Deere \& Company & Mueller Industries Inc & US Concrete Inc \\
\hline Digital Power Corp & Universal Forest Pr Inc \\
\hline Donaldson Company Inc & UQM Technologies Inc \\
\hline
\end{tabular}




\begin{tabular}{|c|c|c|}
\hline Dover Corp & Multi-Fineline Electr Inc & USG Corp \\
\hline Dynamic Materials Corp & Nacco Industries Inc & Valmont Industries Inc \\
\hline Eagle Materials Inc & Napco Security T. Inc & Valpey Fisher Corp \\
\hline Eaton Corp & Navistar Internat Corp & Vault America Inc \\
\hline Echelon Corp & NCI Building Syst. Inc & Veeco Instruments Inc \\
\hline Edac Technologies Corp & Newport Corp & Vicon Industries Inc \\
\hline Electro Scientific Ind Inc & Nexxus Lighting Inc & Vicor Corp \\
\hline Electro-Sensors Inc & NN Inc & Video Display Corp \\
\hline Electronic Control S Inc & Nortech Systems Inc & Vishay Intertech Inc \\
\hline Emerson Electric Co & Northwest Pipe Co. & Wabtec Corp \\
\hline Encore Wire Corp & NVE Corp & Watts Water Tech Inc \\
\hline Energy Conversion D Inc & Omega Flex Inc & Wells Gardner Elec Corp \\
\hline Enersys & OPT Sciences Corp & West Pharmaceut S Inc \\
\hline Ennis Inc & Orbit International Corp & Winland Electronics Inc \\
\hline Enpro Industries Inc & Orbital Sciences Corp & Wireless Telecom G Inc \\
\hline Environmental Tect Corp & Oshkosh Corp & Woodward Inc \\
\hline Espey Manuf \& Elect Corp & OSI Systems Inc & WSI Industries Inc \\
\hline Esterline Technol Corp & Owens Illinois Inc & X-Rite Inc \\
\hline Faro Technologies Inc & Paccar Inc & Xenonics Holdings Inc \\
\hline Federal Signal Corp & Packaging C. of Amer & Zebra Technologies Corp \\
\hline Flir Systems Inc & Pall Corp & Zygo Corp \\
\hline Flow International Corp & \multicolumn{2}{|l|}{ Park Electrochem Corp } \\
\hline
\end{tabular}

\section{Quadro 11 - Amostra de empresas estadunidenses}

Fonte: Dados da pesquisa.

No Quadro 11 estão listadas as 323 empresas que representam, na amostra, as empresas industriais estadunidenses cadastradas na base Thomson que evidenciaram todas as informações, do período analisado neste estudo.

Estas empresas atuam na atividade fabril nos segmentos de: alimentos, bebidas, construção, eletroeletrônicos, máquinas industriais, mineração, minerais não metálicos, papel, celulose, petróleo, gás, química, siderurgia, metalurgia, têxtil, veículos, peças e outros. As mesmas possuem cadastro na SEC e suas ações são negociadas em bolsas de valores, principalmente na New York Stock Exchange (NYSE). 


\begin{tabular}{|l|l|l|}
\hline \multicolumn{3}{|c|}{ Razão Social } \\
\hline 600 Group PLC & Hampson Industries PLC & Renishaw PLC \\
\hline Castings PLC & Hamworthy PLC & Rotork PLC \\
\hline Chamberlin PLC & Hargreaves Services PLC & Senior PLC \\
\hline China Shoto PLC & Howden Joinery G PLC & Smith (DS) PLC \\
\hline Cohort PLC & IMI PLC & Smiths Group PLC \\
\hline Cookson Group PLC & Invensys PLC & Spectris PLC \\
\hline Corac Group PLC & Laird PLC & Surface Transforms PLC \\
\hline Datong PLC & Latham (James) PLC & Tricorn Group PLC \\
\hline Dialight PLC & LPA Group PLC & Trifast PLC \\
\hline Diploma PLC & Lupus Capital PLC & TT Electronics PLC \\
\hline E2V Technolog PLC & Macfarlane Group PLC & Vindon Healthcare PLC \\
\hline Elektron Technol PLC & Meggitt PLC & Vitec Group PLC \\
\hline Energetix Group PLC & Melrose PLC & Weir Group PLC \\
\hline Fenner PLC & Molins PLC & Xaar PLC \\
\hline Goodwin PLC & Oxford Instruments PLC & Zytronic PLC \\
\hline Halma PLC & Premier Farnell PLC \\
\hline
\end{tabular}

\section{Quadro 12 - Amostra de empresas inglesas}

Fonte: Dados da pesquisa.

No Quadro 12 apresentam-se as 47 empresas que representam, na amostra, as empresas industriais inglesas cadastradas na base Thomson que evidenciaram todas as informações, do período analisado neste estudo. As mesmas foram constituídas e estão sediadas na Inglaterra.

Estas empresas atuam na atividade fabril nos segmentos de: construção, eletroeletrônicos, máquinas industriais, mineração, papel, celulose, química, siderurgia, metalurgia, veículos, peças e outras. As mesmas possuem ações negociadas em bolsas de valores, principalmente na London Stock Exchange (LSE).

\subsection{CONSTRUCTOS}

Os constructos da pesquisa visam demonstrar a operacionalização das variáveis. Conforme Richardson (1989), o estudo científico descritivo contém variáveis que devem ser inseridas nos objetivos e/ou nas hipóteses e estas são entendidas como um conceito que assume valores numéricos. No Quadro 13 apresentam-se os constructos desta pesquisa. 


\begin{tabular}{|c|c|c|c|}
\hline Objetivos & $\begin{array}{l}\text { Variá- } \\
\text { veis }\end{array}$ & $\begin{array}{c}\text { Sub- } \\
\text { variáveis }\end{array}$ & $\begin{array}{c}\text { Autores } \\
\text { Base }\end{array}$ \\
\hline \multirow[b]{2}{*}{$\begin{array}{l}\text { a) Identificar a política de } \\
\text { remuneração dos executivos } \\
\text { nas perspectivas de nível e } \\
\text { estrutura, conforme a } \\
\text { proposição de Murphy (1999), } \\
\text { de empresas industriais } \\
\text { brasileiras, estadunidenses e } \\
\text { inglesas, no período de } 2007 \text { a } \\
2010 \text {. }\end{array}$} & Nível & - valor & \\
\hline & Estrutura & $\begin{array}{l}\text { - salário } \\
\text { - bônus } \\
\text { anual } \\
\text { - opções de } \\
\text { ações } \\
\text { - outras } \\
\text { (planos de } \\
\text { incentivos } \\
\text { de longo } \\
\text { prazo, } \\
\text { planos de } \\
\text { benefícios } \\
\text { de } \\
\text { empregados } \\
\text { e etc.) }\end{array}$ & $\begin{array}{l}\text { Murphy } \\
\text { (1999) }\end{array}$ \\
\hline \multirow{3}{*}{$\begin{array}{l}\text { b) Estimar o nível normal de } \\
\text { gerenciamento de resultados a } \\
\text { partir das atividades } \\
\text { operacionais das empresas } \\
\text { pesquisadas, no período de } \\
2007 \text { a 2010, considerando as } \\
\text { despesas com vendas, gerais e } \\
\text { administrativas pelo modelo de } \\
\text { Anderson, Banker } \\
\text { Janakiraman (2003); as } \\
\text { despesas com P\&D pelo } \\
\text { modelo de Gunny (2005); e o } \\
\text { nível de produção pelo modelo } \\
\text { de Roychowdhury (2005). }\end{array}$} & \multirow[t]{2}{*}{$\begin{array}{c}\text { Despesas } \\
\text { discricionárias }\end{array}$} & $\begin{array}{l}\text { - vendas, } \\
\text { gerais e } \\
\text { administra- } \\
\text { tivas }\end{array}$ & $\begin{array}{c}\text { Anderson, } \\
\text { Banker e } \\
\text { Janakira- } \\
\text { man } \\
(2003)\end{array}$ \\
\hline & & $\begin{array}{l}\text { - pesquisa e } \\
\text { desenvolvi- } \\
\text { mento }\end{array}$ & $\begin{array}{l}\text { Gunny } \\
(2005)\end{array}$ \\
\hline & $\begin{array}{c}\text { Decisões } \\
\text { operacionais }\end{array}$ & $\begin{array}{l}\text { - nível de } \\
\text { produção }\end{array}$ & $\begin{array}{c}\text { Roychow- } \\
\text { dhury } \\
(2005)\end{array}$ \\
\hline $\begin{array}{l}\text { c) Estimar o nível normal de } \\
\text { gerenciamento de resultados } \\
\text { das empresas pesquisadas, no } \\
\text { período de 2007 a 2010, a } \\
\text { partir das accruals } \\
\text { discricionárias pelo modelo de } \\
\text { Dechow, Sloan e Sweeney } \\
\text { (1995). }\end{array}$ & Accruals & $\begin{array}{l}\text { - discricio- } \\
\text { nárias }\end{array}$ & $\begin{array}{c}\text { Dechow, } \\
\text { Sloan e } \\
\text { Sweeney } \\
(1995)\end{array}$ \\
\hline
\end{tabular}




\begin{tabular}{|c|c|c|c|}
\hline $\begin{array}{l}\text { d) Analisar a relação da } \\
\text { política de remuneração dos } \\
\text { executivos com o nível de } \\
\text { gerenciamento de resultados, } \\
\text { por meio das atividades } \\
\text { operacionais e das accruals } \\
\text { discricionárias, das empresas } \\
\text { objeto do estudo, no período } \\
\text { de } 2007 \text { a } 2010 \text {. }\end{array}$ & $\begin{array}{c}\text { PRE } \\
\text { GRAO - } \\
\text { DVGA } \\
\text { GRAO - } \\
\text { DP\&D } \\
\text { GRAO - NP } \\
\text { GRAD }\end{array}$ & $\begin{array}{l}\text { - resultado } \\
\text { dos } \\
\text { objetivos } \\
\text { 'a', 'b' e 'c' }\end{array}$ & $\begin{array}{c}\text { Inovação } \\
\text { da tese }\end{array}$ \\
\hline \multirow{5}{*}{$\begin{array}{l}\text { e) analisar a relação da política } \\
\text { de remuneração dos executivos } \\
\text { e do nível de gerenciamento de } \\
\text { resultados, com } \\
\text { características de idade, } \\
\text { expertise e gênero dos } \\
\text { executivos e das características } \\
\text { de homogeneidade, } \\
\text { desempenho e tamanho das } \\
\text { empresas. }\end{array}$} & $\begin{array}{c}\text { PRE - GRAO } \\
- \text { GRAD }\end{array}$ & $\begin{array}{l}\text { - resultado } \\
\text { do objetivo } \\
\text { 'd' }\end{array}$ & $\begin{array}{c}\text { Inovação } \\
\text { da tese }\end{array}$ \\
\hline & \multirow{3}{*}{$\begin{array}{c}\text { Características } \\
\text { do Executivo }\end{array}$} & $\begin{array}{l}\text { - idade: } \\
\text { - menos de } \\
50 \text { anos } \\
\text { - de } 50 \text { a } 65 \\
\text { anos } \\
\text { - mais de } 65 \\
\text { anos }\end{array}$ & $\begin{array}{c}\text { Farrel e } \\
\text { Whidbee } \\
\text { (2003) }\end{array}$ \\
\hline & & $\begin{array}{l}\text { - expertise } \\
\text { (tempo de } \\
\text { trabalho + } \\
\text { formação } \\
\text { em pós- } \\
\text { graduação + } \\
\text { certificação } \\
\text { profissional) }\end{array}$ & $\begin{array}{l}\text { Aier et al. } \\
\text { (2005) }\end{array}$ \\
\hline & & - gênero & $\begin{array}{c}\text { Barua et } \\
\text { al. (2010), } \\
\text { Peni e } \\
\text { Vähämaa } \\
(2010)\end{array}$ \\
\hline & $\begin{array}{c}\text { Características } \\
\text { da Empresa }\end{array}$ & $\begin{array}{l}\text { - segmento } \\
\text { de atuação }\end{array}$ & $\begin{array}{l}\text { Baber, } \\
\text { Kang e } \\
\text { Kumar } \\
(1998)\end{array}$ \\
\hline
\end{tabular}




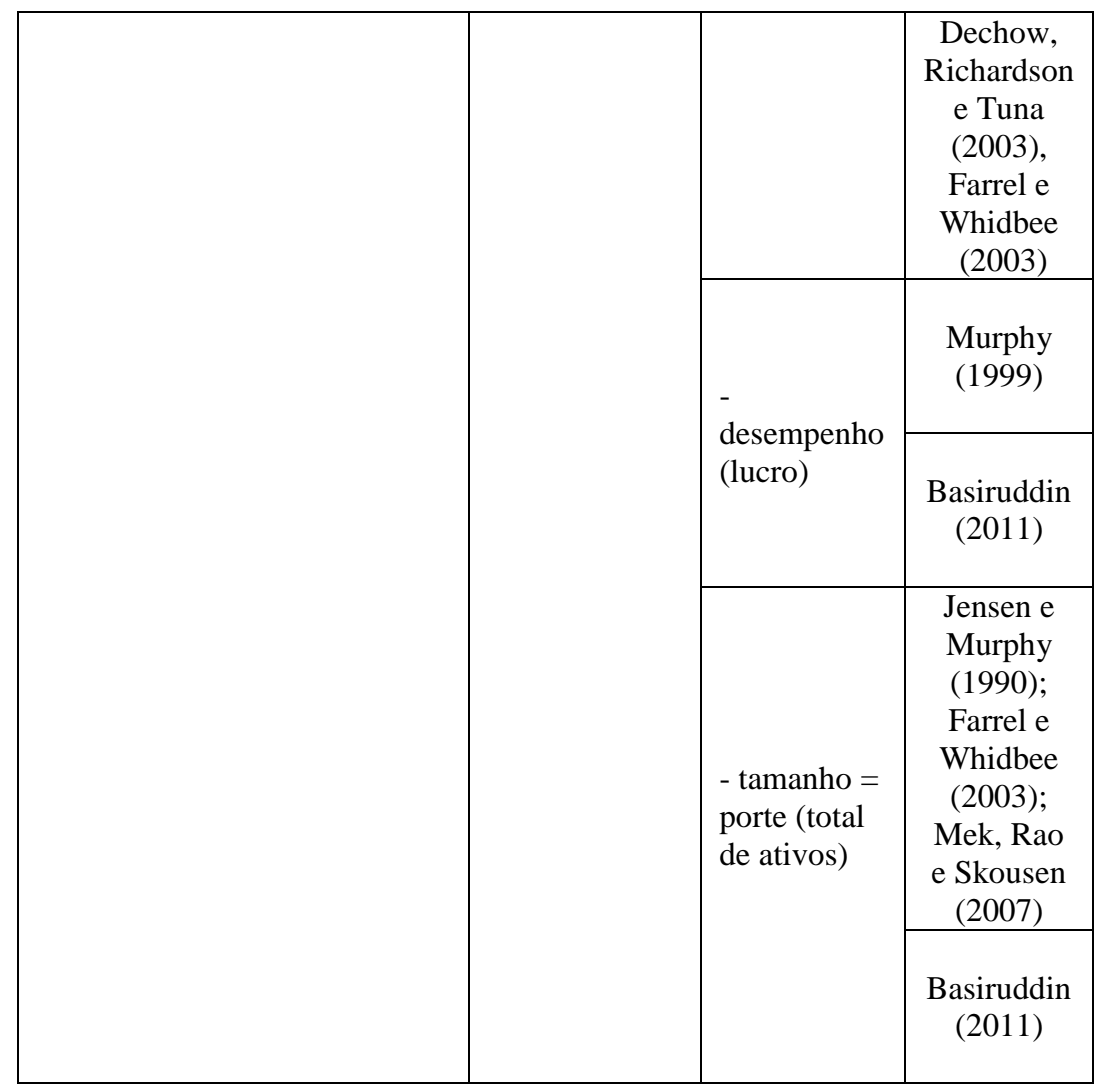

\section{Quadro 13 - Constructos da pesquisa}

Fonte: Elaboração própria.

A seguir apresenta-se a descrição das variáveis em relação a cada objetivo específico da pesquisa:

a) Objetivo específico ' $a$ '

O objetivo 'a' possui a variável nível, que se constitui da subvariável valor, relativa ao valor da remuneração, mensurado em moeda corrente do país de origem. Também consta a variável estrutura, que se compõe das subvariáveis: salário, bônus anual, opções de ações, planos de incentivos de longo prazo e planos de benefícios de empregados. Estas variáveis e subvariáveis são oriundas do trabalho de 
Murphy (1999). A operacionalização dos objetivos desta pesquisa estão representas na equação a seguir:

(Equação 1)

$$
P R E_{i t}=\text { Salário }_{i t}+\text { Bônus }_{i t}+\text { Ações }_{i t}+\text { Outras }_{i t}
$$

Onde:

$P R E=$ política de remuneração do executivo da empresa i no período t;

Salário= remuneração fixa que serve de base de cálculo para outros benefícios da empresa i no período t;

Bônus= plano de bônus anual e/ou participação nos resultados da empresa i no período t;

$A c ̧ o ̃ e s=$ remuneração baseada em ações da empresa i no período $\mathrm{t}$;

Outras = outras formas de remuneração, incluindo benefícios pós-emprego da empresa i no período t.

Destaca-se que, por meio da Equação 1, foi mensurada apenas a remuneração direta, uma vez que a remuneração indireta não foi objeto do estudo por tornar-se de difícil mensuração e quantificação. Dado que as empresas industriais brasileiras não a evidenciam no Formulário de Referência da CVM, as empresas industriais estadunidenses não a evidenciam nos relatórios DEF 14A, 10K e 20F, e as empresas industriais inglesas não a evidenciam em suas demonstrações financeiras.

b) Objetivo específico 'b'

O objetivo 'b' possui as variáveis relativas às despesas discricionárias, que se compõem das subvariáveis: despesas com vendas, gerais e administrativas e despesas com pesquisa e desenvolvimento; e a variável relativa às decisões operacionais, que se constitui da subvariável nível de produção.

Para estimar a manipulação real nas despesas discricionárias relativas às despesas com vendas, gerais e administrativas utilizou-se a equação adotada por Anderson, Banker e Janakiraman (2003), como segue: 
(Equação 10)

$$
\begin{gathered}
\log \left(\frac{D V G A d m_{i t}}{D A G A d m_{i t-1}}\right)=\alpha_{1}+\alpha_{2} \log \left(\frac{\operatorname{Rec}_{i t}}{\operatorname{Rec}_{i t-1}}\right)+ \\
\alpha_{3} \log \left(\frac{\operatorname{Rec}_{i t}}{\operatorname{Rec}_{i t-1}}\right) x D S_{i t}+\alpha_{4} \log \left(\frac{\operatorname{Rec}_{i t-1}}{\operatorname{Rec}_{i t-2}}\right) \\
+\alpha_{5} \log \left(\frac{\operatorname{Rec}_{i t-1}}{\operatorname{Rec}_{i t-2}}\right) x D S_{i t-1}+\varepsilon_{i t}
\end{gathered}
$$

Onde:

$\log =$ logaritmo

$D V G A d m_{i t}=$ despesas com vendas, gerais e administrativas da empresa i no período t;

$D V G A d m_{i t-1}=$ despesas com vendas, gerais e administrativas da empresa i no período $t-1$;

$R e c_{i t}=$ receita líquida da empresa i no período $\mathrm{t}$;

$R e c_{i t-1}=$ receita líquida da empresa i no período $\mathrm{t}-1$;

$D S_{i t}=$ variável categórica que indica o comportamento da receita líquida da empresa $\mathrm{i}$ no período $\mathrm{t}$, sendo 1 quando $R e c_{i t}<R e c_{t-1}$ e 0 quando contrário;

$D S_{i t-1}=$ variável categórica que indica o comportamento da receita líquida da empresa i no período $\mathrm{t}-1$, sendo 1 quando $\operatorname{Rec}_{i t-1}<\operatorname{Rec}_{i t-2}$ e 0 quando contrário;

$\alpha_{0}, \alpha_{1}, \alpha_{2}, \alpha_{3}, \alpha_{4}=$ coeficientes estimados por regressão;

$\varepsilon_{i t}=$ erro da regressão.

Conforme Anderson, Banker e Janakiramam (2003), Zang (2005) e Cardoso e Martinez (2006), é esperado que os coeficientes $\alpha_{2}$ e $\alpha_{4}$ sejam positivos, pois mudanças nas despesas com vendas, gerais e administrativas normalmente acompanham o comportamento da receita líquida. Espera-se que o coeficiente $\alpha_{3}$ seja negativo, porque as despesas com vendas, gerais e administrativas tendem a permanecer constantes no curto prazo. Por fim, espera-se que o coeficiente $\alpha_{5}$ seja positivo, refletindo reversões das despesas com vendas, gerais e administrativas no longo prazo.

Segundo Anderson, Banker e Janakiramam (2003), o uso do log melhora a comparabilidade das variáveis entre as empresas e mitiga a heterocedasticidade. Para os autores, a variável dummy $D S_{t}$ é igual a 
um quando as vendas estão decrescendo e zero quando contrário. Esta é incluída para captar a relação assimétrica entre as despesas com vendas, gerais e administrativas e os níveis de vendas quando as vendas aumentam e diminuem.

Para estimar a manipulação real nas despesas discricionárias relativas às despesas com pesquisa e desenvolvimento utilizou-se o modelo de Gunny (2005), representado na equação descrita a seguir:

(Equação 11)

$$
\begin{array}{ll}
\frac{P \& D_{i t}}{A . T l_{i t-1}} & \\
& =\alpha_{0}+\alpha_{1} \frac{P \& D_{i t-1}}{A . T l_{i t-1}}+\alpha_{2} \frac{F . \text { Int }_{i t}}{A . T l_{i t-1}} \\
& +\alpha_{3} \text { QTobin }_{i t}+\alpha_{4} \frac{\text { Cap }_{i t}}{A . T l_{i t-1}}+\varepsilon_{i t}
\end{array}
$$

Onde:

$P \& D_{i t}=$ despesas com pesquisa e desenvolvimento da empresa i no período t;

$A$. $T l_{i t-1}=$ ativo total da empresa i no período $\mathrm{t}-1$;

$P \& D_{i t-1}=$ despesas com pesquisa e desenvolvimento da empresa i no período t-1;

$F . I n t=$ fundos internos corresponde ao lucro operacional adicionado das despesas com pesquisa e desenvolvimento e acrescido das despesas de depreciação e amortização;

QTobin $_{\text {it }}=$ valor de mercado da empresa $\mathrm{i}$ no período $\mathrm{t}$ dividido pelo custo de reposição de seus ativos;

DCap $i t=$ despesas de capital da empresa i no período t; $\alpha_{0}, \alpha_{1}, \alpha_{2}, \alpha_{3}, \alpha_{4}=$ coeficientes estimados por regressão; $\varepsilon_{i t}=$ erro da regressão.

Segundo Gunny (2005), um gerente interessado em aumentar a receita corrente poderia escolher cortar investimentos em P\&D, particularmente se a percepção do benefício associado com o projeto de $\mathrm{P} \& \mathrm{D}$ perdido beneficiaria a empresa em um período futuro, sem prejudicar os resultados do período atual. A ação de escolher investir em $\mathrm{P} \& \mathrm{D}$ ao invés de consumo desta pode gerar uma miopia nos resultados, 
pois as despesas discricionárias do período estarão sendo reduzidas, no entanto o período futuro estará sendo prejudicado.

Para estimar a manipulação real nas decisões operacionais relativas ao nível de produção utilizou-se o modelo de Roychowdhury (2005), descrito na equação a seguir:

(Equação 12)

$$
\begin{gathered}
\frac{\operatorname{Prod}_{i t}}{A \cdot T l_{i t-1}} \\
=\alpha_{0}+\alpha_{1} \frac{1}{A \cdot T l_{i t-1}}+\alpha_{2} \frac{\operatorname{Rec}_{i t}}{A \cdot T l_{i t-1}} \\
+\alpha_{3} \frac{\Delta \operatorname{Rec}_{i t}}{A \cdot T l_{i t-1}}+\alpha_{4} \frac{\Delta \operatorname{Rec}_{i t-1}}{A \cdot T l_{i t-1}}+\varepsilon_{i t}
\end{gathered}
$$

Onde:

$\operatorname{Prod}_{i t}=$ custo dos produtos vendidos da empresa i no período $\mathrm{t}$, acrescido da variação dos estoques do período t para t-1;

$A . T l_{i t-1}=$ ativo total da empresa i no período $\mathrm{t}-1$;

$R e c_{i t}=$ receita líquida da empresa i no período $t$

$R e c_{i t-1}=$ receita líquida da empresa i no período $\mathrm{t}-1$;

$\Delta R e c_{i t}=$ variação da receita líquida da empresa $\mathrm{i}$ entre o período t e t-1;

$\alpha_{0}, \alpha_{1}, \alpha_{2}, \alpha_{3}, \alpha_{4}=$ coeficientes estimados por regressão;

$\varepsilon_{i t}=$ erro da regressão.

A equação 12 detecta, conforme Roychowdhury (2005), a superprodução, ou seja, aumentando o custo dos estoques, por consequência, o custo dos produtos vendidos, afetando assim o resultado do período. O modelo também detecta manipulação nas vendas, por descontos anormais, ação utilizada para aumentar temporariamente as vendas.

c) Objetivo específico 'c'

O objetivo 'c' possui a variável accruals, que se constitui das subvariáveis: accruals totais e accruals discricionárias.

Para o cálculo do nível de gerenciamento de resultados por accruals discricionárias do segmento de empresas industriais utilizou-se 
o modelo de Dechow, Sloan e Sweeney (1995), conforme equação a seguir:

(Equação 6)

$$
A T_{i t}=\alpha_{0}+\alpha_{1}\left(\Delta \operatorname{Rec}_{i t}-\Delta C \cdot \operatorname{Receb}_{i t}\right)+\alpha_{2}\left(A T \cdot \text { Imob }_{i t}\right)+\varepsilon_{i t}
$$

Onde:

$A T=$ accruals totais da empresa i no período t; accruals totais

$$
\begin{aligned}
& \text { = Acapital circulante líquido } \\
& \text { - depreciação e amortização }
\end{aligned}
$$

$\Delta R e c_{i t}=$ variação das receitas operacionais líquidas da empresa i entre o período t e $\mathrm{t}-1$;

$\Delta C \cdot$ Receb $_{i t}=$ variação das contas a receber líquidas da empresa i entre o período t e t-1;

At. Imob = ativo imobilizado operacional da empresa i no ano $\mathrm{t}$;

$\alpha_{0}, \alpha_{1}, \alpha_{2}=$ coeficientes estimados por regressão.

$\varepsilon_{i t}=$ erro da regressão

OBS: todas as variáveis são escaladas pelos ativos totais em t-1.

d) Objetivo específico 'd'

O objetivo específico ' $d$ ' se constitui na inovação da tese e agrega os três primeiros objetivos específicos 'a', 'b' e 'c'.

Para identificar a relação do percentual da remuneração variável do executivo com o nível de gerenciamento de resultados por meio de atividades operacionais (despesas com vendas, gerais e administrativas, despesas com pesquisa e desenvolvimento e níveis de produção) e de accruals discricionárias, utilizou-se da técnica de correlação canônica, conforme descrito na equação a seguir:

(Equação 13)

$$
\begin{gathered}
\alpha_{1} \text { Salário }_{i t}+\alpha_{2} \text { Bônus }_{i t}+\alpha_{3} \text { Ações }_{i t}+\alpha_{4} \text { Outras }_{i t} \\
=\beta_{1} \text { GRAODVGA } \\
\beta_{2} \text { GRAODP\&D } \\
\text { it }
\end{gathered}
$$


Onde:

Salário ${ }_{i t}=$ remuneração fixa que serve de base de cálculo para outros benefícios da empresa i no período t;

$B$ ônus ${ }_{i t}=$ plano de bônus anual e/ou participação nos resultados da empresa i no período t;

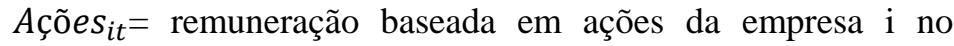
período t;

Outras $_{i t}=$ outras formas de remuneração, incluindo benefícios pós-emprego da empresa i no período t;

GRAODVGA $A_{i t}=$ gerenciamento de resultados por atividades operacionais, despesas com vendas, gerais e administrativas da empresa i no período t;

$G R A O D P \& D_{i t}=$ gerenciamento de resultados por atividades operacionais, despesas com pesquisa e desenvolvimento da empresa i no período t;

$G R A O N P_{i t}=$ gerenciamento de resultados por atividades operacionais, nível de produção da empresa i no período t;

$G R A T_{i t}=$ gerenciamento de resultados por accruals totais da empresa i no período t;

$\alpha_{1}, \alpha_{2}, \alpha_{3}, \alpha_{4}, \beta_{1}, \beta_{2}, \beta_{3}, \beta_{4},=$ coeficientes estimados por regressão.

Como os modelos tiveram todos os seus inputs normalizados, escalados pelo total de ativos do exercício anterior ou pelo seu logaritmo, é possível que constituam uma única regressão. Zang (2005) utilizou como variáveis para seus testes, em uma única regressão, os resultados obtidos das equações 10,11 e 12 , relativos ao gerenciamento de resultados por meio de atividades operacionais. Da mesma forma, Martinez (2006) e Cohen e Zarowin (2008) os utilizaram na mesma matriz de correlação, acrescentando novas proxies de gerenciamento de resultados.

Ressalta-se que a mensuração do gerenciamento de resultados, por meio de atividades operacionais e por accruals, foi efetivada com os resíduos das equações 10,11 e 12. 
e) Objetivo específico 'e'

O objetivo específico ' $\mathrm{e}$ ' possui como variável inicial o resultado do objetivo específico ' $\mathrm{d}$ ', que propõe analisar a relação da política de remuneração dos executivos e do nível de gerenciamento de resultados, com as características de idade, expertise e gênero dos executivos e das características de homogeneidade, desempenho e tamanho das empresas. Nomeou-se esta variável inicial de PRE GRAO - GRAD.

A variável endógena idade foi operacionalizada conforme o estudo de Farrel e Whidbee (2003), que classificou os executivos em duas faixas etárias, considerando um grupo mais jovem, com média de 55 anos, e um grupo mais velho, com média de 64 anos. Dechow e Sloan (1991), Murphy (1999), Engel, Hayes e Wang (2003) e Farrel e Whidbee (2003) destacam que o CEO costuma se aposentar por volta de 64 a 66 anos, fato que torna esta idade proeminente na análise comportamental do CEO perante seu horizonte temporal de atividade na empresa.

Para esta pesquisa realizou-se uma adaptação do estudo de Farrel e Whidbee (2003), não incluindo a idade na regressão, mas sim segregando as empresas da amostra em três grupos, de acordo com a faixa etária de seus executivos: a primeira faixa considerou idades inferiores a 50 anos, a segunda entre 50 e 65 anos e a terceira com idades superiores a 65 anos.

Para a variável endógena expertise seguiu-se o exemplo utilizado no estudo de Aier et al. (2005), que considerou a formação profissional do executivo, abrangendo graduação, especialização, mestrado, doutorado, certificação profissional e experiência de trabalho, em relação ao tempo, mensurado em anos. Para esta pesquisa ocorreu uma adaptação da pesquisa de Aier et al. (2005), que incluiu na regressão uma variável de controle, correspondendo ao valor 'um' se o executivo possuía um dos itens de sua formação ou 'zero' para o caso contrário.

Nesta pesquisa o executivo teve um índice de expertise mensurado conforme o exposto no Quadro 14. 


\begin{tabular}{|l|c|}
\hline \multicolumn{1}{|c|}{ Formação Profissional } & Índice \\
\hline $1^{\text {a }}$ graduação e o mesmo valor para a $2^{\text {a }}$ graduação & 0,25 \\
\hline 1 especialização e o mesmo valor para 2 ou mais & 0,25 \\
\hline 1 mestrado e o mesmo valor para 2 ou mais & 0,25 \\
\hline 1 doutorado e o mesmo valor para 2 ou mais & 0,25 \\
\hline \multicolumn{1}{|c|}{ Certificação profissional } & Índice \\
\hline Certificated Public Accounting ou outros & 0,25 \\
\hline \multicolumn{1}{|c|}{ Experiência profissional } & Índice \\
\hline até 5 anos de experiência de trabalho & 0,10 \\
\hline de 6 a 10 anos de experiência de trabalho & 0,20 \\
\hline de 11 a 15 anos de experiência de trabalho & 0,30 \\
\hline de 16 a 20 anos de experiência de trabalho & 0,40 \\
\hline de 21 a 25 anos de experiência de trabalho & 0,50 \\
\hline de 26 a 30 anos de experiência de trabalho & 0,60 \\
\hline de 31 a 35 anos de experiência de trabalho & 0,70 \\
\hline de 36 a 40 anos de experiência de trabalho & 0,80 \\
\hline mais de 40 anos de experiência de trabalho & 0,90 \\
\hline
\end{tabular}

\section{Quadro 14 - Mensuração da expertise}

Fonte: Elaborado a partir de Aier et al. (2005).

Ao final da mensuração descrita no Quadro 14, o executivo obteria um índice de expertise conforme a sua formação, a sua certificação profissional e o seu tempo de experiência de trabalho. Este índice foi calculado para cada executivo e organizado pela sua frequência. Após, os índices de expertise até a mediana foram segregados para o primeiro grupo, que representa menor expertise, e os valores acima da mediana no segundo grupo, que representa maior expertise. Essa classificação com base na mediana dos dados fundamenta-se na pesquisa de Basiruddin (2011). Por fim, a amostra foi classificada em dois grupos, para análise da relação entre a remuneração dos executivos e o gerenciamento de resultados por atividades operacionais e por accruals discricionárias com a característica de expertise do executivo.

A variável endógena gênero seguiu as pesquisas de Barua et al. (2010) e Peni e Vähämaa (2010), que separaram os CEOs da amostra em gênero feminino e gênero masculino. Desta forma, possibilitou a 
análise da sensibilidade da relação da remuneração dos executivos com o gerenciamento de resultados por atividades operacionais e por accruals discricionárias com a característica do gênero do executivo.

Destaca-se que a titulação de MBA foi considerada como pósgraduação lato sensu para os três países, desconsiderando diferenças de estruturas curriculares educacionais, considerando apenas a evidenciação realizada pelas empresas industriais brasileiras, estadunidenses e inglesas.

Para a segregação das empresas da amostra por segmento de atuação, ao pesquisar estudos anteriores como o de Baber, Kang e Kumar (1998), de Dechow, Richardson e Tuna (2003) e de Farrel e Whidbee (2003), vislumbrou-se o uso de setores ou segmentos de atuação decompostos de formas diferenciadas. O primeiro estudo segregou a amostra nas atividades de: indústrias de base, bens de capital, construção, bens de consumo, energia, serviços financeiros, transporte e utilidades. O segundo e o terceiro consideraram para a segregação da amostra de estudo o código Standard Industrial Classification (SIC) da Security and Exchange Comission (SEC).

Para esta pesquisa consideraram-se estes estudos anteriores, acrescidos da classificação da Bolsa de Mercadorias e Futuros Bovespa (BM\&FBovespa) e da Comissão de Valores Mobiliários (CVM), ressaltando-se que a amostra é composta somente por empresas industriais. Entretanto, os códigos são muito abrangentes e específicos, e tornou a amostra pulverizada, fato que dificultou a análise quantitativa dos dados.

Assim, optou-se por utilizar a divisão de segmentos de atuação da Economática, que se divide da seguinte forma: alimentos e bebidas, construção, eletroeletrônicos, máquinas industriais, mineração, minerais não metálicos, outros, papel e celulose, petróleo e gás, química, siderurgia e metalurgia, têxtil e veículos e peças. Desse modo, a amostra constituiu-se de 13 segmentos de atuação. Porém, o último segmento, veículos e peças, foi adaptado para equipamentos de transporte, de forma a abranger veículos, aviões, trens e navios e suas partes e peças correspondentes.

Quanto à segmentação da amostra por desempenho, esta pesquisa seguiu o estudo de Murphy (1999), que utilizou o lucro como medida de desempenho. No entanto, para que fosse possível segregar a amostra em dois grupos para análise da relação entre a remuneração dos executivos e o gerenciamento de resultados por atividades operacionais e por accruals discricionárias com a característica de desempenho da empresa utilizou-se o método de Basiruddin (2011). Neste, os dados são 
separados até a mediana em um grupo e os valores acima da mediana no segundo grupo.

Quanto à segmentação da amostra por tamanho, esta pesquisa seguiu os estudos de Jensen e Murphy (1990), Farrel e Whidbee (2003) e Mek, Rao e Skousen (2007), que mensuraram o tamanho da empresa pelo total de ativos. No entanto, para que fosse possível segregar a amostra em dois grupos para análise da relação entre a remuneração dos executivos e o gerenciamento de resultados por atividades operacionais e por accruals discricionárias com a característica de tamanho da empresa, utilizou-se o método de Basiruddin (2011). Neste, os dados são separados até a mediana em um grupo e os valores acima da mediana no segundo grupo.

Após a descrição das variáveis e subvariáveis abrangidas pelos objetivos específicos 'a', 'b', 'c', 'd' e 'e' elencados no constructo desta pesquisa, elaboraram-se as hipóteses conforme segue.

\subsection{HIPÓTESES DA PESQUISA}

O gerenciamento de resultados se constitui, conforme Schipper (1989) e Healy e Wahlen (1999), numa intervenção proposital no processo de comunicação externa financeira, com a intenção de obter algum benefício privado que pode ocorrer em qualquer etapa do processo de divulgação externa. $\mathrm{O}$ interesse em gerenciar resultados pode estar relacionado, de acordo com DeAngelo (1986) e Schipper (1989), aos mercados de capitais, as motivações contratuais e as regulamentações.

Healy e Wahlen (1999) destacam que o uso das informações por analistas financeiros na avaliação de ações pode gerar um incentivo para os gestores manipularem os resultados na tentativa de influenciar o desempenho de curto prazo das ações. Outro incentivo para a prática de gerenciamento de resultados advém dos contratos que regulamentam os benefícios e as obrigações entre principal e agente. Também, pode ser de interesse para os organismos de regulação, por possíveis erros nas demonstrações financeiras, que afetam a alocação de recursos ou pelo uso da informação contábil por investidores em ações ou da dívida, conselho de administração, dentre outros. Este estudo se concentra nas motivações contratuais expostas por DeAngelo (1986) e Schipper (1989), compreendida na teoria da agência, em que Jensen e Meckling (1976) descrevem o comportamento oportunístico do agente.

O comportamento oportunístico do agente, conforme Healy (1985), DeAngelo (1986), McNichols e Wilson (1988), McNichols 
(1989), Shipper (1989), Jones (1991), Kang e Sivaramakrisnam (1995), Dechow, Sloan e Sweeney (1996), Key (1997), Ahmed, Takeda e Thomas (1999), Healy e Wahlen (1999), Libby, Kinney Jr. e William (2000), Martinez (2001), Pae (2005), McVay (2006), Roychowdhury (2006), Paulo (2007) e Baptista (2008), levam ao gerenciamento de resultados contábeis com o intuito de afetar as decisões dos usuários externos da empresa.

Healy (1985), DeAngelo (1986) e Schipper (1989) afirmam que há incentivos para o agente efetivar as escolhas contábeis, em razão do seu plano de remuneração estar atrelado aos números contábeis. Dechow e Sloan (1991) salientam que o executivo em anos finais de mandato gerencia resultados para aumentar sua remuneração. $\mathrm{O}$ gerenciamento de resultados também é associado aos planos de bônus (GUIDRY; LEONE; ROCK, 1999), aos aumentos em incentivos patrimoniais (CHENG; WARFIELD, 2005), às participações em opções e ações (BERGSTRESSERA; PHILIPPON, 2006). De acordo com Jensen (1993), quanto mais incentivos ao executivo, mais gerenciamentos de resultados haverá.

Dentre as formas de gerenciamento de resultados existentes, a mais difundida em pesquisas, é por meio de accruals discricionárias. Pesquisadores contemporâneos, como Gunny (2005), Roychowdhury (2005) e Zang (2005), estão disseminando outra forma de gerenciamento de resultados, que se realiza por meio de atividades operacionais. O gerenciamento de resultados contábeis pode ser realizado por meio de manipulação nas contas operacionais da empresa, tais como: despesas com vendas, despesas gerais e administrativas, despesas com pesquisa e desenvolvimento e alterações nos níveis de produção e estoques.

$\mathrm{O}$ gerenciamento de resultados por meio de atividades operacionais e por accruals discricionárias, conforme Zang (2005), é positivamente correlacionado com os incentivos para sua realização, ou seja, se referem aos benefícios advindos do gerenciamento. Para Cardoso e Martinez (2006), as empresas que manipulam suas informações contábeis mediante decisões operacionais utilizam menos accruals discricionárias que as demais empresas. Portanto, para estes últimos autores, uma forma de gerenciamento se sobrepõe a outra, em termos de efetivação.

A literatura citada demonstra possível relação da remuneração do executivo e do gerenciamento de resultados, por meio de atividades operacionais e por accruals discricionárias. Assim, elaboraram-se as hipóteses a seguir, a serem comprovadas por meio de testes estatísticos. 
$\mathrm{H}_{1}$ : Há relação entre a política de remuneração do executivo e o nível de gerenciamento de resultados.

$\mathrm{O}$ resultado esperado do teste da hipótese $\mathrm{H}_{1}$ é de que haja relação entre a política de remuneração do executivo e o gerenciamento de resultados, por meio de atividades operacionais e por accruals discricionárias.

$\mathrm{H}_{1 \mathrm{a}}$ : Há relação positiva entre a política de remuneração do executivo e o nível de gerenciamento de resultados por meio de atividades operacionais, especificamente despesas com vendas e despesas gerais e administrativas.

$\mathrm{H}_{1 \mathrm{~b}}$ : Há relação positiva entre a política de remuneração do executivo e o nível de gerenciamento de resultados por meio de atividades operacionais, especificamente despesas com pesquisa e desenvolvimento.

$\mathrm{H}_{1 c}$ : Há relação positiva entre a política de remuneração do executivo e o nível de gerenciamento de resultados por meio de atividades operacionais, especificamente pelo nível de produção da empresa.

$\mathrm{H}_{1 \mathrm{~d}}$ : Há relação positiva entre a política de remuneração do executivo e o nível de gerenciamento de resultados por accruals discricionárias.

$\mathrm{Na}$ Figura 11 ilustram-se as relações propostas no grupo $1 \mathrm{de}$ hipóteses.

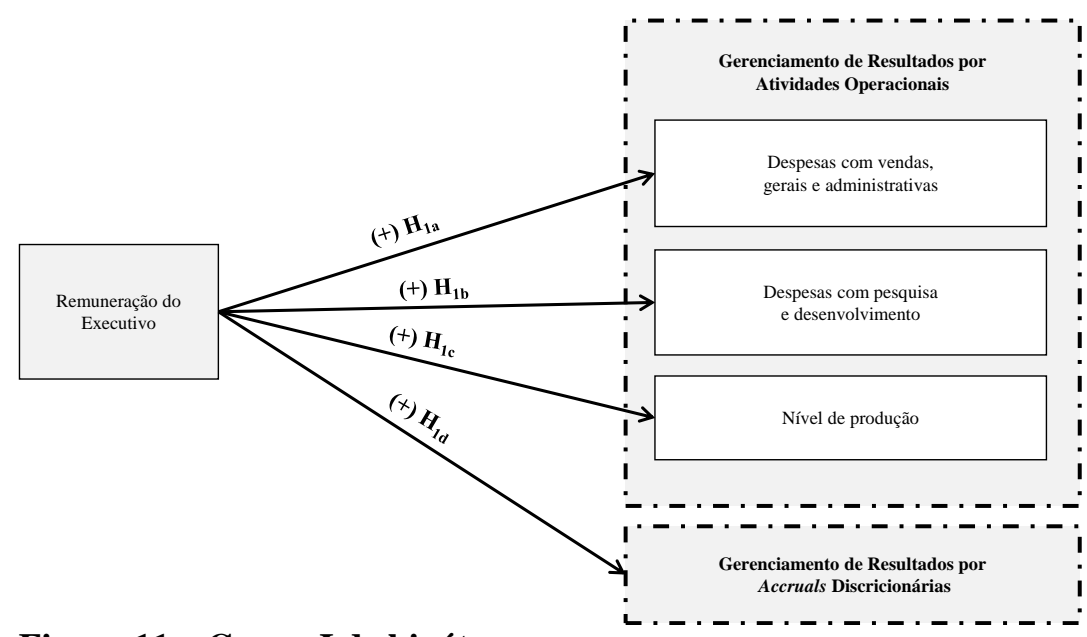

Figura 11 - Grupo I de hipóteses

Fonte: Elaboração própria. 
Os resultados esperados no teste das hipóteses $\mathrm{H}_{1 \mathrm{a}}, \mathrm{H}_{1 \mathrm{~b}}, \mathrm{H}_{1 \mathrm{c}} \mathrm{e}$ $\mathrm{H}_{1 \mathrm{~d}}$ são de que aumentos na política de remuneração do executivo representem aumentos no nível de gerenciamento de resultados.

A remuneração em dinheiro, inserida na política de remuneração de executivos, tem sido alvo de várias pesquisas: associada ao desempenho de mercado e contábil como medida de desempenho do CEO (LAMBERT; LARCKER, 1987), atrelada à riqueza dos acionistas (JENSEN; MURPHY, 1990), discutida no contexto das opções de crescimento da política de remuneração (SMITH JR.; WATSS, 1992), correlacionada com empresas em crescimento. (GAVER; GAVER, 1993), associada às ações de ajuste efetivadas pelo comitê de remuneração (DECHOW; HUSAN; SLOAN, 1994), agregada à persistência de lucros da empresa (BABER; KANG; KUMAR; 1998), relacionada com ganhos acima da meta enquanto os resultados são positivos (GAVER; GAVER, 1998).

A pesquisa de Murphy (1999), que abrangeu a política de remuneração dos principais executivos (CEOs), com base em comparações internacionais de 23 países, no ano de 1997, evidenciou que, dentre as práticas adotadas pelos países estudados, os EUA é o país que deteve o maior nível de remuneração do CEO US\$ 901.000/ano e também o maior nível de remuneração em dinheiro, aproximadamente US\$ 540.000/ano.

Com base na literatura exposta de pesquisas anteriores e no contexto da remuneração em dinheiro contida na política de remuneração dos executivos, segregada por tipo de remuneração no Brasil, nos Estados Unidos da América e na Inglaterra, elaboram-se as hipóteses a seguir, a serem comprovadas por meio de testes estatísticos.

$\mathrm{H}_{2 \mathrm{a}}$ : Países que possuem maior remuneração em dinheiro contida na política de remuneração dos executivos possuem maior nível de gerenciamento de resultados por meio de atividades operacionais, especificamente despesas com vendas e despesas gerais e administrativas.

$\mathrm{H}_{2 \mathrm{~b}}$ : Países que possuem maior remuneração em dinheiro contida na política de remuneração dos executivos possuem maior nível de gerenciamento de resultados por meio de atividades operacionais, especificamente despesas com pesquisa e desenvolvimento.

$\mathrm{H}_{2 \mathrm{c}}$ : Países que possuem maior remuneração em dinheiro contida na política de remuneração dos executivos possuem maior nível de gerenciamento de resultados por meio de atividades operacionais, especificamente pelo nível de produção da empresa. 
$\mathrm{H}_{2 \mathrm{~d}}$ : Países que possuem maior remuneração em dinheiro contida na política de remuneração dos executivos possuem maior nível de gerenciamento de resultados por accruals discricionárias.

Na Figura 12 apresentam-se as relações propostas no grupo 2 de hipóteses.

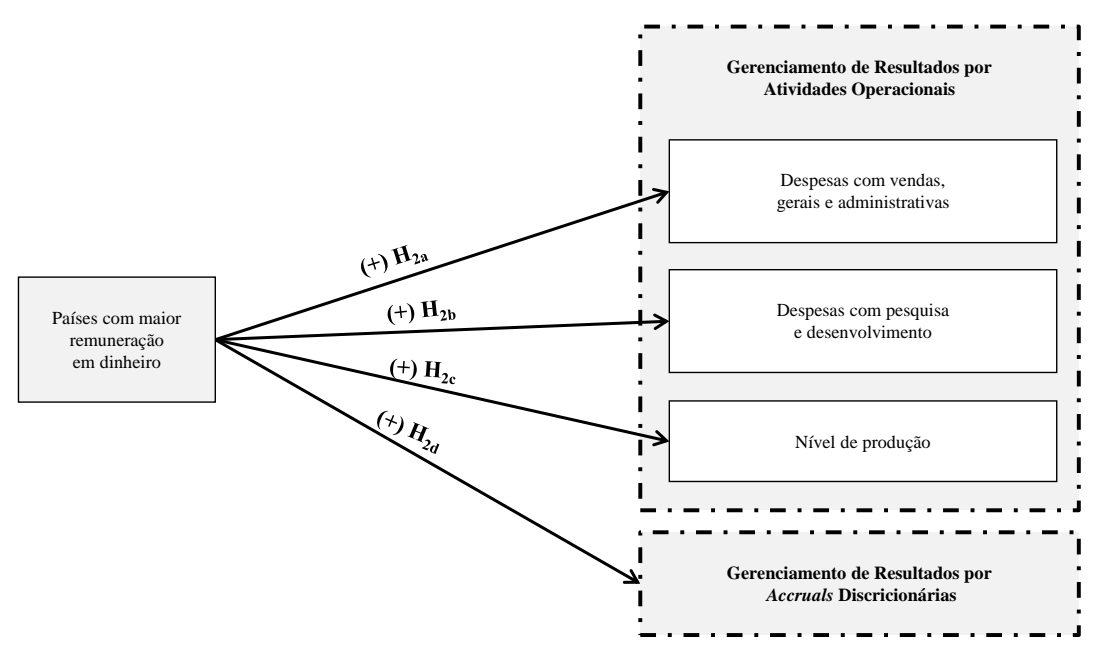

Figura 12 - Grupo II de hipóteses

Fonte: Elaboração própria.

Os resultados esperados do teste das hipóteses $\mathrm{H}_{2 \mathrm{a}}, \mathrm{H}_{2 \mathrm{~b}}, \mathrm{H}_{2 \mathrm{c}} \mathrm{e}$ $\mathrm{H}_{2 \mathrm{~d}}$ são de que países que possuem a maior remuneração em dinheiro, em termos percentuais, incluída na política de remuneração dos executivos, possuam o maior nível de gerenciamento de resultados por meio de atividades operacionais e accruals discricionárias.

Variáveis de controle têm sido utilizadas em diversas pesquisas para as características dos executivos: a) a idade foi pesquisada quanto à suas implicações na remuneração do CEO (MCKNIGHT; TOMKINS; WEIR; HOBSON, 2000), também foi relacionada com a rotatividade do CEO e com o fato da divulgação incluir a idade na divulgação junto ao nome do próximo CEO (FARREL; WHIDBEE; 2003); b) a expertise, que significa tempo de trabalho como CEO, experiência em outras empresas, formação em pós-graduação e certificação profissional (ex.: Certificated Public Accounting - CPA). Empresas cujos CEOs têm mais expertise são significativamente menos propensas a republicar os seus resultados (AIER et al. 2005); c) o gênero, empresas com o CEOs femininas são associadas com o rendimento decrescente de accruals, o 
que implica que CEOs do gênero feminino são mais conservadores e seguem estratégias de gestão de resultados (BARUA et al., 2010; PENI; V ̈̈H ̈̈MAA, 2010).

Com base nas características descritas elaboraram-se as hipóteses a seguir, a serem comprovadas por meio de testes estatísticos.

$\mathrm{H}_{3 \mathrm{a}}$ : A relação da política de remuneração do executivo com o nível de gerenciamento de resultados se modifica se a amostra for estratificada pela variável endógena idade do executivo.

$\mathrm{H}_{3 \mathrm{~b}}$ : A relação da política de remuneração do executivo com o nível de gerenciamento de resultados se modifica se a amostra for estratificada pela variável endógena expertise do executivo.

$\mathrm{H}_{3 c}$ : A relação da política de remuneração do executivo com o nível de gerenciamento de resultados se modifica se a amostra for estratificada pela variável endógena gênero do executivo.

Variáveis de controle utilizadas para as características da empresa incluem: a) a homogeneidade da indústria, que foi correlacionada com a rotatividade do CEO (FARREL; WHIDBEE; 2003); b) o segmento da indústria, associado à persistência de lucros da empresa (BABER; KANG; KUMAR, 1998); c) o desempenho da empresa, em termos de lucro, associado ao plano de remuneração do executivo (MURPHY, 1999); d) o tamanho da empresa, relacionado com o nível de remuneração (JENSEN; MURPHY, 1990), associado à previsão de crescimento quando um estranho é nomeado CEO (FARREL; WHIDBEE, 2003). Tamanho é uma proxy adequada para controlar a assimetria de informação e a força da governança da empresa (MEK; RAO; SKOUSEN; 2007).

Com base nas características descritas elaboraram-se as hipóteses a seguir, a serem comprovadas por meio de testes estatísticos.

$\mathrm{H}_{3 \mathrm{~d}}$ : A relação da política de remuneração do executivo com o nível de gerenciamento de resultados se modifica se a amostra for estratificada pela variável endógena segmento de atuação da empresa.

$\mathrm{H}_{3 \mathrm{e}}$ : A relação da política de remuneração do executivo com o nível de gerenciamento de resultados se modifica se a amostra for estratificada pela variável endógena desempenho da empresa.

$\mathrm{H}_{3 \mathrm{f}}$ : A relação da política de remuneração do executivo com o nível de gerenciamento de resultados se modifica se a amostra for estratificada pela variável endógena tamanho da empresa. 
Na Figura 13 evidenciam-se as relações propostas no grupo 3 de hipóteses.

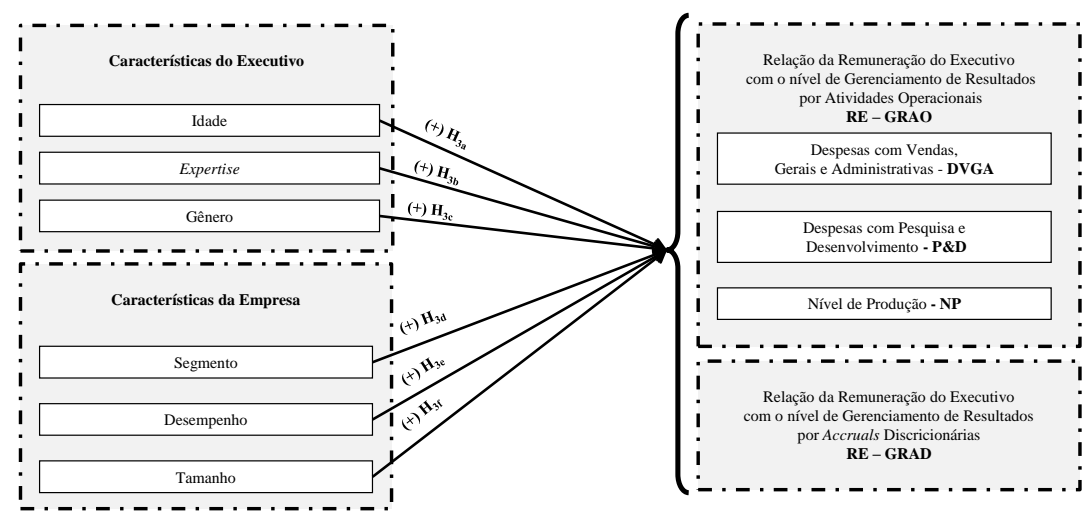

Figura 13 - Grupo III de hipóteses

Fonte: Elaboração própria.

$\mathrm{O}$ resultado esperado do teste da hipótese $\mathrm{H}_{3 \mathrm{a}}$ é de que quanto maior a idade do executivo maior a relação entre a política de remuneração deste e o nível de gerenciamento de resultados.

$\mathrm{O}$ resultado esperado do teste da hipótese $\mathrm{H}_{3 \mathrm{~b}}$ é de que quanto mais expertise o executivo possuir, em termos de experiência em outras empresas, formação em pós-graduação e certificação profissional, maior a relação entre a política de remuneração do executivo e o nível de gerenciamento de resultados.

$\mathrm{O}$ resultado esperado do teste da hipótese $\mathrm{H}_{3 c}$ é de que as empresas com o executivo do gênero masculino possuam maior relação entre a política de remuneração do executivo e o nível de gerenciamento de resultados.

$\mathrm{O}$ resultado esperado do teste da hipótese $\mathrm{H}_{3 \mathrm{~d}}$ é de haja diferença significativa entre a homogeneidade da empresa e a relação da política de remuneração do executivo com o nível de gerenciamento de resultados.

$\mathrm{O}$ resultado esperado do teste da hipótese $\mathrm{H}_{3 \mathrm{e}}$ é de que quanto mais lucro a empresa possuir, maior a relação da política de remuneração do executivo com o nível de gerenciamento de resultados.

$\mathrm{O}$ resultado esperado do teste da hipótese $\mathrm{H}_{3 \mathrm{f}}$ é de que quanto maior o porte da empresa, maior a relação da política de remuneração do executivo com o nível de gerenciamento de resultados. 
Após o embasamento teórico, a definição, a demonstração gráfica e a descrição dos resultados esperados das hipóteses, apresentam-se os procedimentos para a coleta de dados realizados nesta pesquisa.

\subsection{COLETA DE DADOS}

Para Bruyne, Herman e Shouteete (1977, p. 203), “a informação torna-se dado pela própria aplicação das técnicas de coleta de dados, opera-se uma seleção específica segundo as problemáticas da pesquisa ou mesmo segundo as hipóteses de trabalho que orientam a elaboração e a verificação teóricas".

No Quadro 15 apresentam-se informações sobre a fonte de coleta dos dados desta pesquisa.

\begin{tabular}{|l|l|}
\hline \multicolumn{1}{|c|}{ País } & \multicolumn{1}{c|}{ Fonte dos dados da Remuneração dos Executivos } \\
\hline Brasil & $\begin{array}{l}\text { Formulário de Referência da Comissão de Valores } \\
\text { Mobiliários (CVM) }\end{array}$ \\
\hline $\begin{array}{l}\text { Estados Unidos da } \\
\text { América }\end{array}$ & $\begin{array}{l}\text { DEF 14A, 10K ou 20F da Security and Exchange } \\
\text { Commission (SEC) }\end{array}$ \\
\hline Inglaterra & $\begin{array}{l}\text { Notas Explicativas do annual report nos portais } \\
\text { eletrônicos das empresas }\end{array}$ \\
\hline \multicolumn{1}{|c|}{ País } & \multicolumn{1}{c|}{ Fonte dos dados do Gerenciamento de Resultados } \\
\hline Brasil & Base nacional de dados contábeis Economática \\
\hline $\begin{array}{l}\text { Estados Unidos da } \\
\text { América }\end{array}$ & $\begin{array}{l}\text { Base internacional de dados contábeis Thomsom One } \\
\text { Banker }\end{array}$ \\
\hline Inglaterra & $\begin{array}{l}\text { Base internacional de dados contábeis Thomsom One } \\
\text { Banker }\end{array}$ \\
\hline
\end{tabular}

\section{Quadro 15 - Fonte dos dados da pesquisa}

Fonte: Elaboração própria.

A coleta de dados se realizou em duas etapas. A primeira, dos dados contábeis das empresas industriais brasileiras, estadunidenses e inglesas. A segunda, das informações da remuneração dos executivos destas empresas.

No Quadro 16 verifica-se a relação dos itens da coleta dos dados das características dos executivos, evidenciadas pelas empresas, objeto de estudo desta pesquisa. 


\begin{tabular}{|l|}
\hline \multicolumn{2}{|c|}{ Dados coletados - Executivos } \\
\hline Certificação profissional \\
\hline Composição segregada da remuneração \\
\hline $\begin{array}{l}\text { Formação pós-graduação (especialização, mestrado e } \\
\text { doutorado) }\end{array}$ \\
\hline Gênero \\
\hline Idade \\
\hline Tempo de trabalho na empresa e em empresas anteriores \\
\hline
\end{tabular}

\section{Quadro 16 - Dados coletados relativos aos executivos}

Fonte: Elaboração própria.

Os dados coletados para a remuneração dos executivos foram relativos ao período de 2007 a 2010. A certificação profissional, a formação e o tempo de trabalho, atendem a variável denominada expertise definida, anteriormente, no constructo desta pesquisa. A idade e o tempo foram mensurados em quantidade de anos.

No Quadro 17 evidencia-se a relação de itens utilizada na coleta dos dados das características das empresas, objeto de estudo desta pesquisa.

\begin{tabular}{|l|}
\hline \multicolumn{1}{|c|}{ Dados contábeis coletados - Empresas } \\
\hline Ativo imobilizado operacional (planta e equipamentos) \\
\hline Ativo total \\
\hline Contas a receber \\
\hline Custo dos produtos vendidos (CPV) \\
\hline Depreciação e Amortização \\
\hline Despesas c/ P\&D \\
\hline Despesas com vendas, gerais e administrativas \\
\hline Despesas de capital \\
\hline Dívidas de curto e longo prazo \\
\hline Estoques \\
\hline Lucro \\
\hline $\begin{array}{l}\text { Lucro antes dos itens extraordinários = Operating income before } \\
\text { extraordinary itens (IBEI) = lucro operacional }\end{array}$ \\
\hline Valor contábil das ações preferenciais \\
\hline Valor de Mercado da Empresa (MVE) \\
\hline Variação do CCL = Working capital = capital de giro \\
\hline Venda líquida \\
\hline
\end{tabular}

Quadro 17 - Dados coletados relativos às empresas

Fonte: Elaboração própria. 
Os dados das empresas para a mensuração do gerenciamento de resultados foram coletados relativos ao período de 2005 a 2010. Os valores das subvariáveis de 2005 e 2006, embora não tenha sido objeto do estudo, foram utilizados para o cálculo das variações entre os exercícios anteriores que afetaram 2007 em algumas equações das regressões estimadas.

Além dos dados contábeis, foram coletados também os segmentos de atuação das empresas. Estes foram padronizados pelo cadastro da SEC, responsável pela maioria das informações da remuneração dos executivos das empresas da amostra.

Os segmentos de atuação das empresas, conforme definido nos constructos desta pesquisa, foram assim categorizados:

- alimentos e bebidas;

- construção;

- eletroeletrônicos;

- máquinas industriais;

- mineração;

- minerais não metálicos;

- outros;

- $\quad$ papel e celulose;

- químico;

- $\quad$ siderurgia e metalurgia;

- têxtil;

- equipamentos de transporte.

O segmento de petróleo e gás não esteve presente em nenhuma empresa dentre as 400 da amostra.

\subsection{ANÁLISE DE DADOS}

Conforme Marconi e Lakatos (2002), a análise de dados representa a tentativa de evidenciar as relações existentes entre 0 fenômeno estudado e outros fatores, e consiste em três etapas:

a) na interpretação, que diz respeito a compreensão das variáveis;

b) na explicação, que busca esclarecer a origem da variável dependente e da necessidade de encontrar a variável antecedente; e

c) na especificação, que busca explicitar até que ponto a relação entre as variáveis é válida. 
Na Figura 14 evidencia-se uma representação gráfica da tese, demonstrando os antecedentes e consequentes do problema de pesquisa.

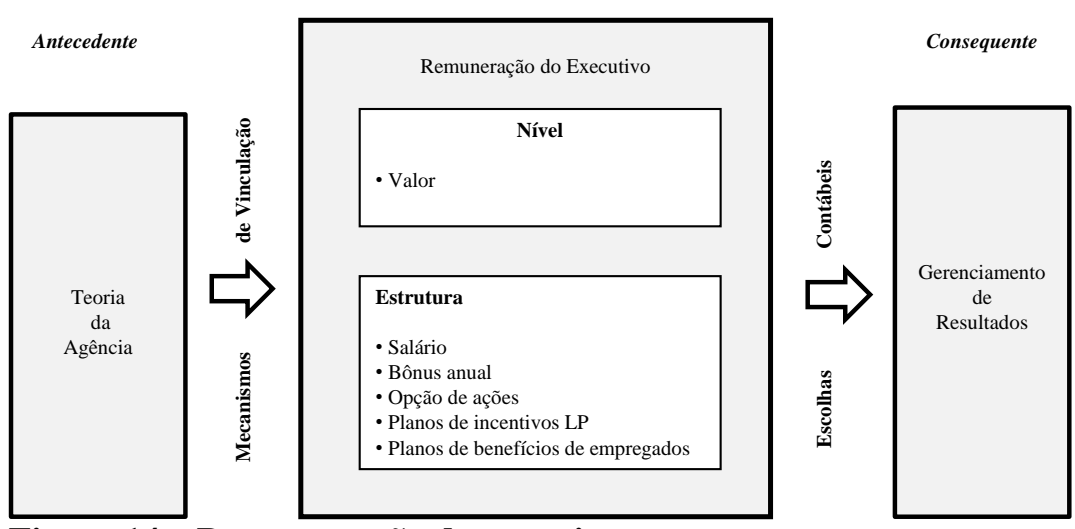

\section{Figura 14 - Representação da pesquisa}

Fonte: Elaboração própria.

Na Figura 15 demonstra-se um fluxograma das etapas da consecução de cada objetivo da pesquisa.
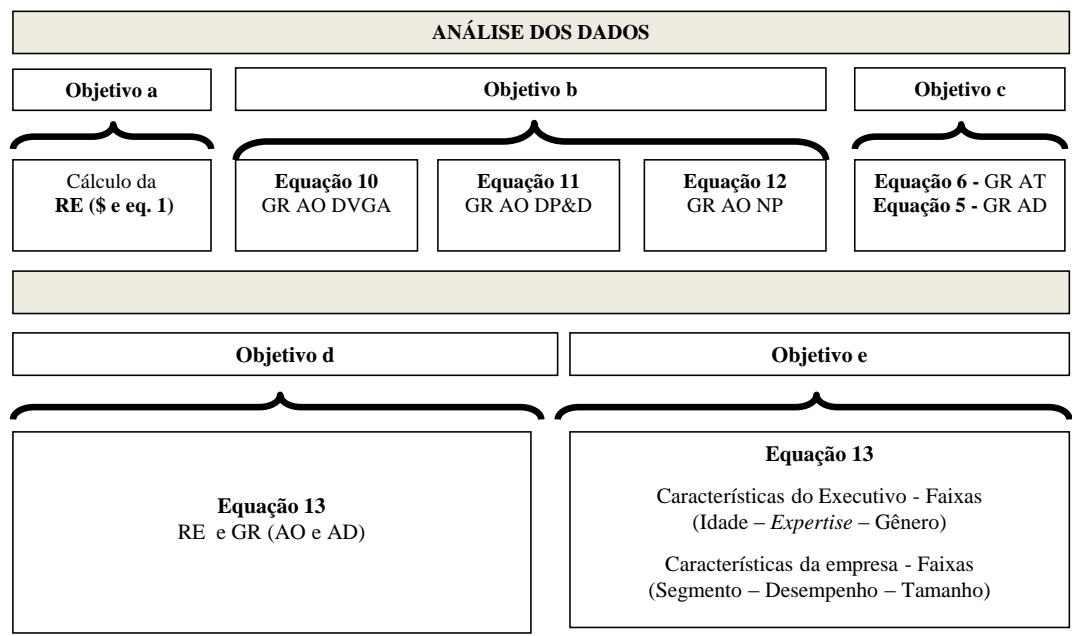

Figura 15 - Sequência lógica da análise dos dados

Fonte: Elaboração própria. 
Observa-se na Figura 14 que a remuneração do executivo no contexto desta tese tem como antecedente a teoria da agência e como consequente o gerenciamento de resultados. A remuneração do executivo é considerada um mecanismo de vinculação da teoria da agência e uma motivação contratual para o gerenciamento de resultados, que se efetiva por meio das escolhas contábeis.

Conforme se observa na Figura 15, o relacionamento entre os objetivos da pesquisa, 'a', 'b', 'c', 'd', e 'e', e o cálculo das variáveis dependeu, para sua efetivação, da utilização de equações. Ambas, variáveis e equações, estão descritas nos constructos da pesquisa.

A análise quantitativa da pesquisa foi realizada por meio de estatística descritiva, regressões lineares múltiplas e correlações canônicas, conforme fórmulas descritas nos constructos desta pesquisa. Da estatística descritiva foram utilizadas a mediana, a média, o desviopadrão, o mínimo e o máximo. As regressões lineares múltiplas foram utilizadas para mensuração dos modelos de gerenciamento de resultados por atividades operacionais e por accruals. Nessas regressões utilizou-se a análise de variância (ANOVA) como referência para afirmar ou não a significância estatística dos modelos.

Hair Jr. et al. (2009) e Lattin, Carrol e Green (2011) destacam que a correlação canônica pode ser vista como uma extensão lógica da análise de regressão múltipla. A diferença fundamental consiste na quantidade de variáveis dependentes métricas. A regressão múltipla utiliza apenas uma única variável dependente métrica, enquanto que a correlação canônica permite relacionar simultaneamente diversas variáveis dependentes métricas.

Conforme Hair Jr. et al. (2009, p. 34), “o princípio subjacente é desenvolver uma combinação linear de cada conjunto de variáveis (independentes e dependentes) para maximizar a correlação entre dois conjuntos". Para Mingoti (2005), a técnica resume a informação de cada conjunto de variáveis-resposta em combinações lineares, sendo que a escolha dos coeficientes dessas combinações é feita tendo-se como critério a maximização da correlação entre os conjuntos de variáveisresposta. Essas combinações lineares construídas são denominadas de variáveis canônicas, enquanto que a correlação entre elas é chamada de correlação canônica.

Conforme Mingoti (2005, p. 144-145), convencionalmente define-se o primeiro par de variáveis canônicas como o par que contém as combinações lineares: 
$U_{1}=a_{1}{ }^{\prime} X$ e $V_{1}=b_{1}{ }^{\prime} Y$ onde $a_{1}$ e $b_{1}$ são vetores de constantes de dimensões $p \times 1$ e $q \times 1$, respectivamente, escolhidos de modo que a correlação entre as variáveis $U_{1}$ e $V_{1}$ seja máxima e tais que essas novas duas variáveis tenham variância iguais a 1 , isto é, $\operatorname{Var}\left(U_{1}\right)=$ $\operatorname{Var}\left(V_{1}\right)=1$.

O segundo par de variáveis canônicas, segundo Mingoti (2005, p. 145) é definido como aquele que contém as combinações lineares:

$U_{2}=a_{2}{ }^{\prime} X$ e $V_{2}=b_{2}{ }^{\prime} Y$ e onde $a_{2}$ e $b_{2}$ são vetores de constantes de dimensões $p \times 1$ e $q \times 1$, respectivamente, escolhidos de modo que a correlação entre as variáveis $U_{2}$ e $V_{2}$ seja maximizada no conjunto das combinações lineares de $X$ e $Y$, que são não correlacionadas com o primeiro par de variáveis canônicas $U_{1} \mathrm{e}$ $V_{1}$. Além disso, onde $a_{2}$ e $b_{2}$ são tais que, : $\operatorname{Var}\left(U_{2}\right)=\operatorname{Var}\left(V_{2}\right)=1$.

Mingote (2005, p. 145) destaca ainda que:

de um modo geral, o $k$-ésimo par de variáveis canônicas é definido como sendo o par contendo as combinações lineares $U_{k}$ e $V_{k}$ tais que : $U_{k}=a_{k}{ }^{\prime} X$ e $V_{k}=b_{k}{ }^{\prime} Y$ onde $a_{k}$ e $b_{k}$ são vetores de constantes de dimensões $p x 1$ e $q x 1$, respectivamente, e escolhido de modo que a correlação entre as variáveis $U_{k}$ e $V_{k}$ seja maximizada no conjunto das combinações lineares de $X$ e $Y$ que têm variáveis iguais a 1 e que são não correlacionadas com as (k-1) primeiras variáveis canônicas. A correlação entre as variáveis $U_{k}$ e $V_{k}$ é chamada de correlação canônica, $k=1,2, \ldots, \min (p, q)$. Uma questão que surge naturalmente é de como encontrar os vetores de constantes $a_{k} \mathrm{e}$ $b_{k^{\prime}} k=1,2, \ldots, \min (p, q)$ que satisfaçam os critérios estabelecidos para a construção dos pares de variáveis canônicas.

Mingote (2005) esclarece que os vetores $a_{k}$ e $b_{k}$ são soluções do seguinte sistema de equações: $\left\{\begin{array}{l}\left(\Sigma_{X Y} \Sigma_{Y Y}^{-1} \Sigma_{Y X}-\lambda_{k} \Sigma_{X X}\right) a_{k}=0 \\ \left(\Sigma_{Y X} \Sigma_{X X}^{-1} \Sigma_{X Y}-\lambda_{k} \Sigma_{Y Y}\right) b_{k}=0\end{array}\right.$ 


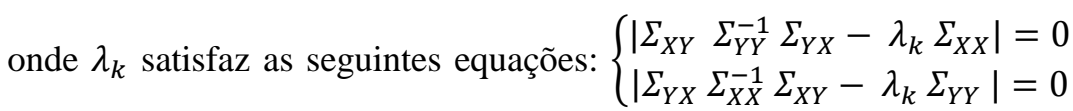
ou seja, $\lambda_{k}$ é o $k$-ésimo maior autovalor da matriz $\left(\Sigma_{X Y} \Sigma_{Y Y}^{-1} \Sigma_{Y X}-\right.$ $\left.\lambda_{k} \Sigma_{X X}\right)$ ou, equivalentemente, da matriz $\left(\Sigma_{Y X} \Sigma_{X X}^{-1} \Sigma_{X Y}-\lambda_{k} \Sigma_{Y Y}\right)$.

Sejam as matrizes $X_{400 \times 4}$ e $Y_{400 \times 4}$, a tabela das 400 empresas brasileiras, estadunidenses e inglesas e seus 4 períodos analisados da remuneração dos executivos, representadas por $X$ e $Y$ a tabela das mesmas empresas, porém com os seus 4 períodos do gerenciamento de resultados, o que se pretende é estabelecer as relações:

(Equação 14)

$$
a_{1} X_{1}+a_{2} X_{2}+a_{3} X_{3}+\cdots+a_{m} X_{m}=b_{1} Y_{1}+b_{2} Y_{2}+b_{3} Y_{3}+\cdots+b_{n} Y_{n}
$$

Onde:

$$
\begin{aligned}
& Y=\text { variáveis dependentes } \\
& X=\text { variáveis independentes } \\
& N=\text { número máximo de variáveis }
\end{aligned}
$$

Fávero et al. (2009, p. 506) destacam que a correlação canônica "pode ser aplicada sem que necessariamente as variáveis métricas apresentem normalidade". Hair Jr. et al. (2009) complementam que a ausência de normalidade não prejudica o método, no entanto, a normalidade é desejada.

Diante do exposto, optou-se pela utilização da técnica multivariada de correlação canônica para verificar a relação entre a política de remuneração de executivos, segregadas em partes percentuais relativas ao salário, bônus, remuneração baseada em ações e outras remunerações e o gerenciamento de resultados por meio de atividades operacionais e por meio de accruals discricionárias. O conjunto de variáveis dependentes é oriundo da remuneração dos executivos e o conjunto de variáveis independentes do gerenciamento de resultados.

De acordo com Santos, Rengel e Hein (2009), com relação à inferência estatística, há um teste para verificar se as matrizes de variáveis são, ou não, correlacionadas entre si. Entretanto, esse teste somente se aplica quando a normalidade multivariada é válida. Como o software utilizado para o cálculo das correlações é o Statgraphics, em sua versão 16.1.15, estes testes já se apresentam por default. 
Na resolução do objetivo específico 'c', de estimar o nível normal de gerenciamento de resultados das empresas pesquisadas, no período de 2007 a 2010, a partir das accruals discricionárias pelo modelo de Dechow, Sloan e Swenney (1995), utilizou-se a adaptação do Índice de Gini para demonstrar a disparidade das accruals discricionárias entre as empresas da amostra.

Conforme Moura Neto (2008, p. 194), o Índice de Gini é "uma medida de desigualdade na distribuição da riqueza. O Índice de Gini varia de zero a um. Quanto mais perto de zero, mais igualitária é a distribuição da riqueza e, contrariamente, quanto mais perto de um, mais discrepante é a distribuição". A adaptação se refere à modulação dos valores de gerenciamento de resultados, pois o índice de Gini não se aplica a valores negativos, apenas valores entre ' 0 ' e ' 1 '. Define-se o Índice de Gini pela equação a seguir:

$$
G=\frac{T}{2 N^{2} \mu}
$$

(Equação 15)

Onde:

$G=$ Índice de Gini

$T=$ soma dos valores da amostra

$N=$ total de observações

$\mu=$ média da variável

O índice de Gini, que avalia os parâmetros distributivos, pode ser definido como duas vezes a área de desigualdade e foi utilizado neste trabalho para demonstrar o grau de concentração das accruals discricionárias das empresas da amostra.

Após o cálculo das regressões, ou seja, dos modelos para os cálculos do gerenciamento de resultados e das correlações canônicas que propiciaram a operacionalização dos objetivos da pesquisa e do Índice de Gini adaptado para demonstrar a desigualdade e concentração do gerenciamento de resultados nas empresas da amostra, por accruals discricionárias, foi realizado o teste de hipóteses.

Por meio da estatística inferencial é possível testar se uma hipótese é verdadeira ou falsa. Segundo Richardson (1989) e Appolinário (2006), a associação entre duas variáveis em um grupo podem utilizar como teste de hipóteses a análise da covariância, quiquadrado, continência, correlação, coeficiente de Yule, ou coeficiente 
Cramer. Nesta pesquisa utilizou-se a análise de correlação canônica para testar as hipóteses, dado que esta, conforme Fávero et al. (2009, p. 506), "quantifica a força da relação existente entre dois vetores de variáveis". Assim alcançou-se os resultados das hipóteses que analisaram as relações entre as variáveis deste estudo.

\subsection{TRAJETÓRIA DA PESQUISA}

Marconi e Lakatos (2002) descrevem que as fases da pesquisa envolvem: a escolha do tema, o levantamento dos dados, a formulação do problema, a definição dos termos, a construção de hipóteses, a indicação das variáveis de estudo, a delimitação do estudo, a definição da amostra, a seleção de métodos e técnicas de pesquisa, a organização do instrumental de pesquisa, a coleta de dados, a análise e interpretação dos dados e a elaboração das conclusões.

$\mathrm{Na}$ Figura 16 demonstram-se, sinteticamente, estas fases, aplicadas nesta pesquisa, agrupadas em quatro etapas explícitas, as demais se encontram implícitas.

\begin{tabular}{|c|c|c|c|c|c|c|}
\hline \multicolumn{7}{|c|}{ TRAJETÓRIA DA PESQUISA } \\
\hline 育 & $\begin{array}{c}\text { Definição do Problema } \\
\text { de Pesquisa }\end{array}$ & \multicolumn{5}{|c|}{$\begin{array}{l}\text { Definição do Objetivo Geral da Pesquisa } \\
\text { Identificar a influência da política de remuneração dos executivos no nível de gerenciamento de resultados sob a ótica } \\
\text { das escolhas contábeis por meio de atividades operacionais e accruals discricionárias, em empresas industriais } \\
\text { brasileiras, estadunidenses e inglesas. }\end{array}$} \\
\hline \multirow[b]{2}{*}{ 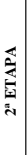 } & Trajetória & \multicolumn{4}{|c|}{ Definição da Estrutura da Revisão de Literatura } & \multirow{2}{*}{$\begin{array}{l}\text { Posicionamento Teórico } \\
\text { RE: Murphy (1999) } \\
\text { GR: Anderson, Banker e } \\
\text { Janakiraman (2003), Gunny (2005), } \\
\text { Roychowdhury (2006), Dechow, } \\
\text { Richardson e Tuna (2003), Jones } \\
\text { (1991) }\end{array}$} \\
\hline & $\begin{array}{l}\text { Epistemológica } \\
\text { Definição da Teoria de } \\
\text { Base: Teoria da Agência } \\
\text { - Jensen e Meckling } \\
\text { (1976) }\end{array}$ & \multicolumn{4}{|c|}{$\begin{array}{ll}\text { Remuneração do Executivo } & \text { Gerenciamento de Resultados } \\
\text { Componentes da Remuneração } & \text { Escolhas Contábeis } \\
\text { Políticas de Remuneração } & \text { Formas de GR } \\
\text { Regulamentação } & \text { Tipos de GR } \\
\text { Estudos de Aplicação } & \text { Modelos de Mensuração } \\
& \text { Estudos de Aplicação }\end{array}$} & \\
\hline 畜 & \multicolumn{3}{|c|}{$\begin{array}{l}\text { Remuneração variável, Gerenciamento de } \\
\text { Resultados por atividades operacionais (Despesas } \\
\text { com vendas, gerais e administrativas, despesas } \\
\text { com P\&D, níveis de produção) e por Accruals } \\
\text { Discricionárias }\end{array}$} & \multicolumn{3}{|c|}{$\begin{array}{l}\text { Grupo 1: Remuneração do executivo com gerenciamento de Resultados por atividades } \\
\text { operacionais e accruals discricionárias. } \\
\text { Grupo 2: Países com maior remuneração em dinheiro com Gerenciamento de resultados por } \\
\text { atividades operacionais e accruals discricionários. } \\
\text { Grupo 3: Características do executivo e da empresa com a relação encontrada no objetivo "d" }\end{array}$} \\
\hline 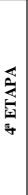 & \multicolumn{2}{|c|}{$\begin{array}{l}\text { Coleta de Dados } \\
\text { Remuneração do Executivo } \\
\text { Segregação da RE e características } \\
\text { do executivo pelo FR CVM, Proxy } \\
\text { Circular SEC e DEFs da ING. } \\
\text { Gerenciamento de Resultados } \\
\text { Valores Contábeis e características } \\
\text { da empresa - Bases Thomson e } \\
\text { Economática }\end{array}$} & \multicolumn{3}{|c|}{$\begin{array}{l}\text { Análise dos Dados } \\
\text { Objetivo a: Cálculo \% da RE; Objetivo b: Cálculo das } \\
\text { regressões GR por AO DVGA, DP\&D e NP. Objetivo c: } \\
\text { Cálculo das regressões de accruals totais e discricionárias. } \\
\text { Objetivo d: Cálculo da correlação canônica da RE com GR } \\
\text { AO e AD. Objetivo e: Análise de sensibilidade - Cálculo da } \\
\text { correlação canônica entre as características do executivo e da } \\
\text { empresa com o resultado do objetivo "d" por faixas } \\
\text { estratificadas da amostra. }\end{array}$} & $\begin{array}{l}\text { Resultado } \\
\text { Resposta a questão: Qual a influência } \\
\text { da política de remuneração dos } \\
\text { executivos no nível de gerenciamento } \\
\text { de resultados sob a ótica das escolhas } \\
\text { contábeis, por meio de atividades } \\
\text { operacionais e accruals discricionárias, } \\
\text { em empresas industriais brasileiras, } \\
\text { estadunidenses e inglesas? }\end{array}$ \\
\hline
\end{tabular}

\section{Figura 16 - Trajetória da pesquisa}

Fonte: Elaboração própria. 
Na Figura 16 verifica-se que a pesquisa iniciou, pela definição do problema de pesquisa. A segunda etapa abrangeu a elaboração da base teórica, que se compõe da trajetória epistemológica, da revisão de literatura e do posicionamento teórico. A terceira etapa consistiu na definição das variáveis e hipóteses de pesquisa. A quarta etapa é relativa à coleta e análise de dados, que culminou com o resultado da pesquisa, que se refere à resposta ao problema de pesquisa proposto.

\subsection{LIMITAÇÕES DA PESQUISA}

As limitações desta pesquisa decorrem de quatro aspectos principais: mensuração de gerenciamento de resultados, países escolhidos como objeto de estudo, período abrangido pela pesquisa e efeitos econômicos.

Sobre a mensuração do gerenciamento de resultados, a utilização dos modelos empregados está sujeita ao viés de variáveis omitidas ou a erros de especificação ou de mensuração, devido à classificação das accruals, ou seja, devido a dificuldade em isolar as accruals discricionárias, também observada por Basiruddin (2011), Dechow et al. (2011) e Martinez (2011).

Segundo Dechow et al. (2011), o tamanho da empresa tem sido identificado como uma variável potencial omitida nos modelos de mensuração de gerenciamento de resultados. Também, se a empresa está em fase de crescimento, ou em situação de mudança extrema, as características das accruals discricionárias devem persistir.

Para minimizar o efeito de variáveis omitidas, procurou-se na execução desta pesquisa (i) ampliar a quantidade de observações, perfazendo um total de 1.600 observações, (ii) estudar apenas um segmento econômico, o das empresas industriais, garantido assim a homogeneidade da amostra, (iii) efetuar a análise dos resultados por faixas estratificadas da amostra com base em características dos executivos e das empresas.

Desse modo, os resultados desta pesquisa devem ser interpretados com cautela, pois as conclusões são restritas aos dados e amostra analisados. Também é valido ressaltar que os resultados dos testes estatísticos realizados não permitem generalizações para a população.

Sobre os países escolhidos como objeto deste estudo, a opção pelo Brasil, Estados Unidos da América e Inglaterra desconsiderou as diferenças internacionais existentes, tais como: contingências, regulamentações, configurações institucionais, estruturas de governança, 
pulverização do capital. Utilizando-se do raciocínio lógico-dedutivo pode-se esperar que países que não são comparáveis entre si, ao serem pesquisados conjuntamente, demonstrem resultados empíricos distintos. No entanto, só é possível verificar tais resultados ao finalizar a execução da pesquisa. Pesquisas com empresas de países diferentes podem fornecer insights sobre diferenças ou semelhanças internacionais em determinado tema. Investigações empíricas desse tipo se tornam necessárias para ampliar o escopo científico do corpo de conhecimento existente.

O período de estudo de 2006 a 2010 se constitui em limitação porque é um período de transição da convergência para as normas internacionais de contabilidade. Os países estão em diferentes etapas de implantação das International Financial Reporting Standards (IFRS), fato que se reflete nas demonstrações contábeis desses países.

Neste mesmo período, fatores econômicos afetaram os três países, como a crise Subprime. Conforme a Central Intelligence Agency United States of America (2010), esta iniciou no País em 2006, foi divulgada em 2007, se refletiu em forte crise econômica em 2008. Desta forma impactou vários países, inclusive o Brasil, com queda na bolsa de valores em 2008 e na redução das exportações, tendo em vista a queda da demanda gerada pelos Estados Unidos. Em 2008, a crise financeira global atingiu a economia da Inglaterra, de forma particularmente difícil, devido à importância do seu setor financeiro, diante do setor primário e secundário.

Segundo a mesma fonte, os Estados Unidos concentra o maior e mais influente mercado financeiro do mundo, possui as principais bolsas de valores, como a National Association of Securities Dealers Automated Quotations (NASDAQ), a New York Stock Exchange (NYSE), a American Stock Exchange (AMEX) e a CME Group (CME). Assim, a limitação desta pesquisa refere-se ao fato de não se ter capturado efeitos econômicos, como os da crise Subprime ou o tamanho do mercado de capitais separadamente, pois os mesmos estão implícitos nas Demonstrações Financeiras dos três países analisados. 


\section{DESCRIÇÃO E ANÁLISE DOS RESULTADOS}

Este capítulo descreve e analisa os resultados da pesquisa, de acordo com os objetivos específicos estabelecidos. Inicia pelo perfil da amostra, que compreende os executivos e as empresas. Em seguida expõe as políticas de remuneração, nas perspectivas de nível e estrutura para as empresas industriais brasileiras, estadunidenses e inglesas. $\mathrm{Na}$ sequência discorre sobre o gerenciamento de resultados a partir das atividades operacionais; com relação às despesas com vendas, gerais e administrativas; as despesas com pesquisa e desenvolvimento; e o nível de produção das empresas industriais dos três países. Também discorre sobre o gerenciamento de resultados a partir das accruals discricionárias.

Após, o estudo evidencia a relação da política de remuneração dos executivos com o nível de gerenciamento de resultados. Segue-se a relação estudada com a segregação da amostra em características do executivo, em específico: idade; expertise, composta pela formação do executivo, desde a graduação até o doutorado, o tempo de experiência de trabalho e a certificação profissional; e o gênero. Também foram segregadas subamostras de acordo com as características da empresa, são elas: o segmento de atuação da empresa industrial, com ênfase em sua atividade principal; o desempenho, mensurado pelos lucros anuais de cada empresa; e o tamanho, mensurado pelo total dos ativos.

A relação das empresas da amostra, juntamente com os dados contábeis, foi obtida da base de dados nacional Economática para as empresas industriais brasileiras e da base de dados internacional Thomson para as empresas industriais estadunidenses e inglesas. Nestas bases coletaram-se os dados do período de 2005 a 2010, compreendendo o total do ativo, lucro/prejuízo, despesas com vendas, gerais e administrativas, vendas líquidas, depreciação e amortização, despesas de capital, lucro operacional, estoques, contas a receber, imobilizado operacional e capital de giro.

Os dados relativos à remuneração dos executivos, para o período de 2007 a 2010, foram obtidos, para as empresas industriais brasileiras no banco de dados da Comissão de Valores Mobiliários (CVM), para as estadunidenses na Securities and Exchange Commission (SEC) e para as inglesas nos portais eletrônicos de cada empresa, no link relativo a informações para investidores. $\mathrm{Na}$ CVM buscou-se o Formulário de Referência, na SEC o Formulário DEF 14A, 10K ou 20F e nos portais das empresas inglesas o annual report. 


\subsection{PERFIL DA AMOSTRA}

No perfil da amostra buscou-se evidenciar características dos executivos e das empresas a que estes estão vinculados.

\subsubsection{Executivos}

Com relação aos executivos, na Tabela 2 apresenta-se a idade do executivo presidente, cargo assim denominado para as empresas industriais brasileiras, Chief Executive Officer (CEO) para as estadunidenses e Chief Financial Officer (CFO) para as inglesas, vinculados às empresas estudadas.

Tabela 2 - Idade dos executivos

\begin{tabular}{|c|c|c|c|c|c|}
\hline \multirow{2}{*}{ Idade dos executivos } & \multicolumn{5}{|c|}{ BRA } \\
\hline & obs & $\%$ & $\min$ & máx & $\mu$ \\
\hline Menos de 50 anos & 25 & 20,8 & 38 & 49 & 43,0 \\
\hline De 50 a 65 anos & 74 & 61,7 & 50 & 65 & 57,1 \\
\hline Mais de 65 anos & 20 & 16,7 & 66 & 81 & 73,1 \\
\hline Não informado & 1 & 0,8 & - & - & - \\
\hline Total & 120 & 100 & - & - & - \\
\hline \multirow{2}{*}{ Idade dos executivos } & \multicolumn{5}{|c|}{ EUA } \\
\hline & obs & $\%$ & $\min$ & máx & $\mu$ \\
\hline Menos de 50 anos & 201 & 15,6 & 31 & 49 & 45,5 \\
\hline De 50 a 65 anos & 853 & 66,0 & 50 & 65 & 57,4 \\
\hline Mais de 65 anos & 228 & 17,6 & 66 & 95 & 70,9 \\
\hline Não informado & 10 & 0,8 & - & - & - \\
\hline Total & 1292 & 100 & - & - & - \\
\hline \multirow{2}{*}{ Idade dos executivos } & \multicolumn{5}{|c|}{ ING } \\
\hline & obs & $\%$ & $\min$ & máx & $\mu$ \\
\hline Menos de 50 anos & 80 & 42,6 & 38 & 49 & 45,6 \\
\hline De 50 a 65 anos & 93 & 49,5 & 50 & 65 & 55,7 \\
\hline Mais de 65 anos & 1 & 0,5 & 66 & 66 & 66,0 \\
\hline Não informado & 14 & 7,4 & - & - & - \\
\hline Total & 188 & 100 & - & - & - \\
\hline
\end{tabular}

Fonte: Dados da pesquisa. 
Verifica-se na Tabela 2 que, para as 30 empresas brasileiras, 323 estadunidenses e 47 inglesas obtiveram-se respectivamente 120 , 1.292 e 188 observações, ou seja, uma observação a cada ano, por empresa no período de 2007 a 2010. Os executivos foram segregados em três faixas etárias: a primeira de um grupo mais jovem, com menos de 50 anos; a segunda de um grupo mediano, de 50 a 65 anos; e a terceira de um grupo com idade acima de 65 anos.

Pode-se observar que o executivo mais jovem possui 31 anos e o mais idoso 95, ambos atuam nas empresas industriais estadunidenses analisadas. Para os três países a faixa etária mais relevante, ou seja, em que houve a maior quantidade de executivos, foi a faixa de 50 a 65 anos, sendo de $61,7 \%$ para as empresas industriais brasileiras, de $66 \%$ para as estadunidenses e $49,5 \%$ para as inglesas.

A média da segunda faixa se manteve próxima para os três países, sendo de 57,1 para os executivos brasileiros, de 57,4 para os estadunidenses e de 55,7 anos para os ingleses. Assim, dentre os executivos estudados, a maior incidência está entre 55,4 e 57,1 anos. Este resultado é semelhante ao das pesquisas realizadas nos Estados Unidos, de Farrel e Whidbee (2003), que obtiveram média, aproximada, de 55 anos para o grupo mais jovem; e de Engel, Hayes e Wang (2003), que obtiveram média, aproximada, de 58 anos para os executivos pesquisados.

Para a idade dos executivos ingleses esta pesquisa identificou uma faixa etária intermediária, média de 55,7 anos, mínimo de 38 e máximo de 66. A pesquisa de Mcnight et al. (2000), com executivos do Reino Unido, revelou resultados semelhantes, média de 55 anos, com mínimo de 42 e máximo de 69 anos.

Nas empresas industriais inglesas houve um percentual maior do que nos outros países, com relação às idades não informadas, de 7,4\% contra 0,8\% para o Brasil e os Estados Unidos da América. Esse resultado pode estar atrelado ao fato de que as informações não continham o mesmo padrão de apresentação. As empresas estadunidenses seguiram o padrão SEC e as brasileiras o padrão CVM de divulgação da remuneração dos executivos. As inglesas divulgaram a remuneração dos executivos nas demonstrações contábeis e notas explicativas, sem um formulário próprio com campos específicos, fato que favorece a divulgação parcial de informações.

Para Mcknight et al. (2000), à medida que aumenta a idade do $\mathrm{CEO}$, as capacidades intelectuais do executivo são aprimoradas devido ao conhecimento e a experiência adquirida com a posição, também com a concretização de sua formação. Nesta pesquisa o entendimento é 
assemelhado, pois o executivo ao obter maior capacidade intelectual, aumenta as possibilidades de escolhas por ações organizacionais que alcancem os seus objetivos pré-determinados.

Outro aspecto investigado diz respeito ao gênero do executivo presidente ou CEO das empresas industriais estudadas, cujos resultados constam na Tabela 3.

Tabela 3 - Gênero dos executivos

\begin{tabular}{l|c|c|c|c|c|c|c|c}
\hline \multirow{2}{*}{$\begin{array}{c}\text { Gênero dos } \\
\text { executivos }\end{array}$} & \multicolumn{2}{|c|}{ BRA } & \multicolumn{2}{c|}{ EUA } & \multicolumn{2}{c|}{ ING } & \multicolumn{2}{c}{ Total } \\
\cline { 2 - 9 } & obs & $\boldsymbol{\%}$ & obs & $\boldsymbol{\%}$ & obs & \% & obs & \% \\
\hline Feminino & 4 & 3,3 & 4 & 0,3 & 4 & 2,1 & 12 & 0,8 \\
Masculino & 116 & 96,7 & 1288 & 99,7 & 184 & 97,9 & 1588 & 99,2 \\
\hline \multicolumn{1}{c}{ Total } & $\mathbf{1 2 0}$ & $\mathbf{1 0 0}$ & $\mathbf{1 . 2 9 2}$ & $\mathbf{1 0 0}$ & $\mathbf{1 8 8}$ & $\mathbf{1 0 0}$ & $\mathbf{1 . 6 0 0}$ & $\mathbf{1 0 0}$ \\
\hline
\end{tabular}

Fonte: Dados da pesquisa.

Nota-se na Tabela 3 que os executivos são, na maioria, do gênero masculino para as empresas industriais dos três países, com um percentual de $99,2 \%$, contra $0,8 \%$ do gênero feminino. A relevância desta verificação coaduna com Barua et al. (2010) e Peni e Vähämaa (2010), de que o gênero do executivo está associado: a) a qualidade na elaboração das demonstrações financeiras das empresas e, por consequência, na qualidade das accruals; e b) as diferenças nas ações organizacionais e decisões contábeis. Conforme os autores, as executivas tendem a serem mais cautelosas, mais conservadoras e menos agressivas nas decisões financeiras.

Barua et al. (2010) comprovaram, pela pesquisa realizada nos Estados Unidos, que as empresas com CEOs femininas possuem menos accruals anormais e menores erros de estimativa do que aquelas que possuem CEOs masculinos. Tendo em vista que esses fatores implicam na qualidade das decisões e das informações financeiras divulgadas verificou-se o gênero. Entretanto, os resultados demonstraram predominância masculina dentre os executivos analisados, este fato pode estar relacionado à cultura destes países e/ou ao conservadorismo deste segmento econômico.

Embasado na pesquisa de Aier et al. (2005), esta pesquisa também buscou características de expertise do executivo presidente. Esta denominação inclui a formação profissional, abrangendo graduação, especialização, mestrado, doutorado, certificação 
profissional e experiência de trabalho, em relação ao tempo, mensurado em anos.

Na Tabela 4 evidenciam-se a formação e o curso na primeira graduação dos executivos que atuam nas empresas industriais estudadas.

Tabela 4 - Formação dos executivos

\begin{tabular}{|c|c|c|c|c|c|c|c|c|}
\hline \multirow{2}{*}{ Formação } & \multicolumn{2}{|c|}{ BRA } & \multicolumn{2}{|c|}{ EUA } & \multicolumn{2}{|c|}{ ING } & \multirow{2}{*}{ Total } & \multirow{2}{*}{$\%$} \\
\hline & obs & $\%$ & obs & $\%$ & obs & $\%$ & & \\
\hline 1 graduação & 112 & 93,3 & 457 & 35,4 & 83 & 44,1 & 652 & 40,8 \\
\hline 2 graduações & 70 & 58,3 & 53 & 4,1 & 16 & 8,5 & 139 & 8,7 \\
\hline 1 especialização & 58 & 48,3 & 144 & 11,1 & 24 & 12,8 & 226 & 14,1 \\
\hline $\begin{array}{l}2 \text { ou mais } \\
\text { especializações }\end{array}$ & 16 & 13,3 & 2 & 0,2 & 0 & 0,0 & 18 & 1,1 \\
\hline Mestrado & 2 & 1,7 & 151 & 11,7 & 14 & 7,4 & 167 & 10,4 \\
\hline Doutorado & 2 & 1,7 & 59 & 4,6 & 2 & 1,1 & 63 & 3,9 \\
\hline $\begin{array}{l}\text { Certificação } \\
\text { profissional - CPA }\end{array}$ & 0 & 0,0 & 41 & 3,2 & 0 & 0,0 & 41 & 2,6 \\
\hline \multirow{2}{*}{$\begin{array}{l}\text { Curso na 1a } \\
\text { graduação }\end{array}$} & \multicolumn{2}{|c|}{ BRA } & \multicolumn{2}{|c|}{ EUA } & \multicolumn{2}{|c|}{ ING } & \multirow{2}{*}{ Total } & \multirow{2}{*}{$\%$} \\
\hline & obs & $\%$ & obs & $\%$ & obs & $\%$ & & \\
\hline Administração & 50 & 41,7 & 74 & 5,8 & 13 & 6,9 & 137 & 8,5 \\
\hline $\begin{array}{l}\text { Biomedicina/ } \\
\text { Biotecnologia / } \\
\text { Medicina }\end{array}$ & 0 & 0,0 & 12 & 0,9 & 0 & 0,0 & 12 & 0,8 \\
\hline Ciências contábeis & 4 & 3,3 & 44 & 3,4 & 22 & 11,7 & 70 & 4,4 \\
\hline $\begin{array}{l}\text { Ciências militares / } \\
\text { Direito }\end{array}$ & 12 & 10,0 & 14 & 1,1 & 0 & 0,0 & 26 & 1,6 \\
\hline Economia & 11 & 9,2 & 30 & 2,3 & 4 & 2,1 & 45 & 2,8 \\
\hline Engenharia & 27 & 22,4 & 226 & 17,5 & 36 & 19,1 & 289 & 18,1 \\
\hline Licenciaturas & 8 & 6,7 & 57 & 4,4 & 8 & 4,3 & 73 & 4,6 \\
\hline Não informado & 8 & 6,7 & 835 & 64,6 & 105 & 55,9 & 948 & 59,2 \\
\hline Total & 120 & 100,0 & 1.292 & 100,0 & 188 & 100,0 & 1.600 & 100,0 \\
\hline
\end{tabular}

Fonte: Dados da pesquisa.

Verifica-se na Tabela 4 a quantidade de observações relativas à formação dos executivos das empresas industriais estudadas, ou seja, 120, 1.292 e 188, respectivamente, no Brasil, Estados Unidos e Inglaterra. Nota-se que as empresas brasileiras tiveram maior divulgação 
da formação de seus executivos, 93,3\%, contra 35,4\% das empresas estadunidenses e $44,1 \%$ das inglesas. Também foi para o Brasil o maior índice de executivos que realizaram a segunda graduação, pois das 120 observações, $58,3 \%$ possuíam mais de uma formação acadêmica.

Com relação à formação em pós-graduação, lato sensu e stricto sensu, no caso especialização, Master Business Administration (MBA), mestrado e doutorado, observa-se que, em termos percentuais, os executivos brasileiros possuem maior índice de qualificação em nível de especialização $48,3 \%$. Para duas ou mais especializações os executivos brasileiros também se destacaram com 13,3\% das observações. Sobre a formação acadêmica em nível de mestrado e doutorado o destaque foi para os executivos estadunidenses, com $11,7 \%$ e 4,6\% das observações. Salienta-se que para nenhum dos executivos brasileiros e ingleses analisados foi evidenciado possuir certificação profissional, do tipo Certified Public Accountant (CPA), embora os exames de certificação sejam realizados nestes países.Por sua vez, os estadunidenses estiveram representados por apenas 3,2\% do total de 1.292 observações.

Dentre as 1.600 observações totais, dos três países, apenas $40,8 \%$ das empresas industriais divulgaram a formação de seus executivos, incluindo o curso de graduação. Os Estados Unidos da América e a Inglaterra obtiveram os maiores índices de não divulgação, com $64,6 \%$ e $55,9 \%$, respectivamente.

Essas diferenças de formação dos executivos dos três países talvez possam ser explicadas por questões conjunturais, particularmente as regulatórias de cada país, como por exemplo, o ensino na graduação dos três países. A formação na graduação em administração de empresas ou áreas afins no Brasil demanda, em média, 4 anos de estudos, em apenas 1 turno diário. Nos Estados Unidos da América, exemplifica-se com a Universidade de Ohio, ou na Inglaterra, com a Universidade de Birmingham, a graduação na área de administração ou negócios é realizada no mesmo tempo, porém em período integral, com uma carga horária/aula superior à brasileira e o estudante sai formado com uma ênfase, o que corresponde a uma especialização lato sensu brasileira. Esta última pode ser uma das razões que leva os executivos americanos e ingleses a procurar menos cursos de especialização do que os brasileiros.

Segundo Aier et al. (2005), o background financeiro, contábil ou gerencial do CEO pode desempenhar um papel importante na determinação da qualidade dos relatórios financeiros. Assim, complementando a análise das informações relativas à formação dos executivos das empresas pesquisadas, com relação ao curso de formação 
na graduação destes executivos, o curso de graduação que se destaca entre os executivos das empresas brasileiras é o de administração, com $41,7 \%$ das observações, enquanto que para os executivos estadunidenses e ingleses o destaque é para o curso de engenharia. Este fato pode estar atrelado à atividade econômica desenvolvida pelas empresas da amostra, no caso fabril. Aproximadamente $18,1 \%$ dos executivos, na soma dos três países, optaram pelo curso de engenharia, seguido pelo curso de administração, com 8,5\%. Aier et al. (2005) destacam que um background contábil seria desejável, visto que o CEO supervisiona a implementação dos princípios de contabilidade, procedimentos e preparação de relatórios financeiros, bem como controles internos e auditoria.

Destaca-se que grande parte da amostra de empresas industriais pesquisadas não evidenciou o curso de formação de seus executivos. Adicionalmente, ressalta-se que as licenciaturas abrangeram os cursos de artes, biologia, ciências sociais, educação, física, letras, matemática e química.

$\mathrm{Na}$ Tabela 5 complementam-se as informações de expertise com o tempo de experiência dos executivos pesquisados. Levou-se em consideração um turnover de 5 anos do CEO para definir as faixas, conforme o estudo de Farrel e Whidbee (2000).

\section{Tabela 5 - Tempo de trabalho dos executivos}

\begin{tabular}{l|c|c|c|c|c|c|c|c}
\hline \multirow{2}{*}{$\begin{array}{c}\text { Tempo de } \\
\text { Experiência }\end{array}$} & \multicolumn{2}{|c|}{ BRA } & \multicolumn{2}{c|}{ EUA } & \multicolumn{2}{c|}{ ING } & \multicolumn{2}{c}{ Total } \\
\cline { 2 - 9 } & obs & $\%$ & obs & $\%$ & obs & $\%$ & obs & $\%$ \\
\hline Até 5 anos & 0 & 0,0 & 24 & 1,9 & 0 & 0,0 & 24 & 1,5 \\
De 6 a 10 anos & 1 & 0,8 & 140 & 10,8 & 11 & 5,9 & 152 & 9,5 \\
De 11 a 15 anos & 6 & 5,0 & 191 & 14,8 & 34 & 18,1 & 231 & 14,4 \\
De 16 a 20 anos & 19 & 15,8 & 215 & 16,6 & 33 & 17,6 & 267 & 16,7 \\
De 21 a 25 anos & 9 & 7,5 & 190 & 14,7 & 24 & 12,8 & 223 & 13,9 \\
De 26 a 30 anos & 8 & 6,7 & 216 & 16,7 & 28 & 14,9 & 252 & 15,8 \\
De 31 a 35 anos & 12 & 10,0 & 133 & 10,3 & 4 & 2,1 & 149 & 9,3 \\
De 36 a 40 anos & 17 & 14,2 & 97 & 7,5 & 0 & 0,0 & 114 & 7,1 \\
Acima de 40 anos & 7 & 5,8 & 58 & 4,5 & 0 & 0,0 & 65 & 4,1 \\
Não informado & 41 & 34,2 & 28 & 2,2 & 54 & 28,7 & 123 & 7,7 \\
\hline \multicolumn{1}{c}{ Total } & 120 & 100,0 & 1.292 & 100,0 & 188 & 100,0 & 1.600 & 100,0 \\
\hline
\end{tabular}

Fonte: Dados da pesquisa. 
Na Tabela 5 nota-se que, para os executivos das empresas brasileiras, o tempo de experiência se concentra na faixa de 16 a 20 anos, considerando-se o tempo de atuação entre a empresa atual e empresas anteriores. Para os executivos estadunidenses a concentração maior foi nas faixas de 26 a 30 anos e de 16 a 20 anos de trabalho, respectivamente. Nas empresas inglesas a concentração maior está na faixa de 11 a 15 anos de trabalho. Destaca-se que esta informação não está atrelada a idade dos executivos, apenas refere-se ao tempo de trabalho destes executivos, conforme evidenciado pelas empresas.

Para Macknight et al. (2000), o CEO acumula mais bens patrimoniais pessoais quando possui mais tempo de experiência de trabalho. De forma geral, entre os três países, não houve similaridade entre as faixas listadas como experiência de trabalho. Entretanto, apenas o Brasil se destacou por possuir representatividade nas faixas acima de 35 anos. Esse fato, conforme a pesquisa de Aier et al. (2005), pode representar que quanto mais experiência o executivo possuir, menor a possibilidade de republicação das demonstrações financeiras. Por fim, a maior concentração geral foi na faixa de 16 a 20 anos, com 16,7 \% das observações.

Em síntese, o perfil do executivo presidente das empresas desta pesquisa demonstrou que a idade média dos executivos se concentrou entre 55,4 e 57,1 anos; o gênero predominante foi o masculino; a formação na graduação que prevaleceu foi a de engenharia, seguida de administração de empresas, os executivos brasileiros buscaram se especializar mais que os executivos estadunidenses e ingleses; e o tempo de trabalho foi diverso entre os três países.

\subsubsection{Empresas}

A seguir, estão expostas as características das empresas industriais brasileiras, estadunidenses e inglesas pesquisadas. As empresas foram segmentadas de acordo com sua atividade principal, ou seja, aquela que compõe o seu faturamento relevante. Inicialmente utilizaram-se as informações cadastrais na base de dados da Economática, para as empresas industriais brasileiras, e da Thomson para as empresas industriais estadunidenses e inglesas. Em seguida utilizaram-se os cadastros da CVM para as empresas industriais brasileiras, da SEC para as estadunidenses e das Demonstrações Financeiras para as inglesas.

Devido à diversidade de produtos fabris existentes, efetuou-se a classificação dos segmentos de atuação das empresas em 12 grupos, 
seguindo a divisão da Economática, que sintetiza a tipologia de empresas, conforme exposto na Tabela 6.

Tabela 6 - Segmento de atuação das empresas

\begin{tabular}{l|c|c|c|c|c|c|c|c}
\hline \multirow{2}{*}{\multicolumn{1}{c|}{ Segmento }} & \multicolumn{2}{|c|}{ BRA } & \multicolumn{2}{c|}{ EUA } & \multicolumn{2}{c|}{ ING } & \multicolumn{2}{c}{ Total } \\
\cline { 2 - 9 } & $\boldsymbol{f}$ & $\mathbf{\%}$ & $\boldsymbol{f}$ & $\mathbf{\%}$ & $\boldsymbol{f}$ & $\mathbf{\%}$ & $\boldsymbol{f}$ & $\mathbf{\%}$ \\
\hline Alimentos e bebidas & 3 & 10,0 & 0 & 0,0 & 0 & 0,0 & 3 & 0,7 \\
Construção & 0 & 0,0 & 18 & 5,6 & 1 & 2,0 & 19 & 4,8 \\
Eletroeletrônicos & 2 & 6,7 & 123 & 38,1 & 15 & 31,9 & 140 & 35,0 \\
Máquinas Industriais & 0 & 0,0 & 63 & 19,5 & 11 & 23,4 & 74 & 18,5 \\
Mineração & 0 & 0,0 & 1 & 0,3 & 2 & 4,3 & 3 & 0,7 \\
Minerais não metálicos & 1 & 3,3 & 2 & 0,6 & 0 & 0,0 & 3 & 0,7 \\
Outros & 2 & 6,7 & 32 & 9,9 & 2 & 4,3 & 36 & 9,0 \\
Papel e celulose & 1 & 3,3 & 16 & 5,0 & 4 & 8,5 & 21 & 5,3 \\
Químico & 1 & 3,3 & 1 & 0,3 & 2 & 4,3 & 4 & 1,0 \\
Siderurgia e metalurgia & 9 & 30,0 & 25 & 7,7 & 7 & 14,9 & 41 & 10,3 \\
Têxtil & 8 & 26,7 & 2 & 0,6 & 0 & 0,0 & 10 & 2,5 \\
Equipamentos de & 3 & 10,0 & 40 & 12,4 & 3 & 6,4 & 46 & 11,5 \\
Transporte & $\mathbf{3 0}$ & $\mathbf{1 0 0 , 0}$ & $\mathbf{3 2 3}$ & $\mathbf{1 0 0 , 0}$ & $\mathbf{4 7}$ & $\mathbf{1 0 0 , 0}$ & $\mathbf{4 0 0}$ & $\mathbf{1 0 0 , 0}$ \\
\hline \multicolumn{1}{c}{ Total } & \multicolumn{7}{c}{}
\end{tabular}

Fonte: Dados da pesquisa.

A segregação das categorias, conforme se observa na Tabela 6, iniciou pelo código de atividades de atuação cadastrado na CVM, na SEC e na descrição da atividade nas Demonstrações Financeiras das empresas inglesas. Entretanto, devido às divergências existentes entre os cadastros, as categorias foram padronizadas de acordo com as denominações de segmento da SEC, que utiliza o código Standard Industrial Classification (SIC) para especificação da atividade preponderante da empresa. Após esta padronização as empresas foram segregadas pelas categorias utilizadas pela Economática para as empresas industriais.

Dentre as empresas industriais brasileiras, o destaque foi para o segmento de siderurgia e metalurgia, com 30,0\% da amostra; seguido pelo têxtil, com $26,7 \%$. Entre as empresas industriais estadunidenses e inglesas o destaque foi para o segmento de eletroeletrônicos, com 38,1\% e $31,9 \%$, respectivamente. Dessa forma, no somatório dos três países, essa foi a categoria que se sobressaiu, com $35,0 \%$ da amostra total. 
De acordo com U.S. Census Bureau (2010), a indústria de manufatura dos Estados Unidos da América é a maior do mundo, produz grandes quantidades de matérias primas e bens de consumo, estando concentrada nos Estados da Região Central e Nordeste, com crescimento se concentrando no Sul do país atualmente. Para a Central Intelligence Agency United States of America (2010), entre os principais produtos fabricados estão os computadores, softwares e os produtos eletrônicos. A indústria siderúrgica americana é a maior do mundo, embora possua forte concorrência da indústria siderúrgica de outros países, como o Brasil, o Canadá e a África do Sul.

O Brasil, de acordo com o Instituto Brasileiro de Geografia e Estatística (IBGE) (2011), teve em 2010 um crescimento no setor industrial de $10,5 \%$ frente ao ano de 2009 , e as maiores contribuições incluem o setor de siderurgia, com $23,4 \%$, e metalurgia, com $17,4 \%$.

Segundo o UK National Statistics (2012), o setor manufatureiro do Reino Unido, do qual a Inglaterra faz parte, em 2010 recuperou-se totalmente da crise, ou seja, em 2010 seu desempenho se igualou, em média, aos patamares anteriores a crise sofrida em 2008, apresentando elevado impacto no setor fabril no ano de 2009. No entanto, o setor de serviços não teve a mesma performance, fato que prejudicou a média de crescimento da economia da Inglaterra, Escócia, País de Gales e Irlanda do Norte, no fechamento do ano de 2010. A estatística também destaca o grande volume de exportações de eletroeletrônicos do Reino Unido para os Estados Unidos. Conforme a Central Intelligence Agency United States of America (2010), o Reino Unido é a terceira maior economia da Europa, mas enfrenta crescentes déficits públicos e níveis da dívida, por isso o governo iniciou um programa de austeridade de cinco anos, que visa reduzir o déficit orçamentário da capital da Inglaterra, Londres, em mais de 10\% do PIB em 2010 para cerca de 1\% até 2015.

Depreende-se do exposto a relevância da representatividade do setor de eletroeletrônicos para os Estados Unidos e Inglaterra e de siderugia e metalurgia para o Brasil, bem como do segmento fabril para os três países.

Com relação aos estudos anteriores, a pesquisa de Baber, Kang e Kumar (1998) teve maior presença na amostra de indústrias de bens de consumo; e em segundo lugar, de bens de capital. Dechow, Richardson e Tuna (2003) e Farrel e Whidbee (2003), ao analisarem a homegeneidade da indústria não divulgaram a atividade exercida pelas empresas, pois utilizaram os dígitos do código Standard Industrial Classification (SIC) da Securities and Exchange Commission (SEC) 
para realizar seus testes estatísticos. Assim, os resultados desta pesquisa assemelham-se aos da pesquisa de Baber, Kang e Kumar (1998).

$\mathrm{Na}$ Tabela 7 relaciona-se o desempenho, em termos de lucro líquido, das empresas industriais da amostra analisada. A estatística descritiva e o lucro líquido de cada empresa, por país, foram mensurados com base no resultado contábil do exercício social de 2010, por se constituir no mais atual, no período analisado. Os valores estão descritos em milhares de dólares americanos, assim como no estudo de Murphy (1999). Utilizou-se o critério de Basiruddin (2011), separando dois grupos por meio da mediana da amostra, o primeiro grupo foi denominado de menores lucros e o segundo grupo de maiores lucros.

Tabela 7 - Desempenho das empresas

\begin{tabular}{l|r|r|r}
\hline $\begin{array}{c}\text { Estatística descritiva - } \\
\text { Lucro Líquido (mi US\$) }\end{array}$ & \multicolumn{1}{c|}{ BRA } & \multicolumn{1}{c|}{ EUA } & \multicolumn{1}{c}{ ING } \\
\hline Média & 57.130 & 117.833 & 61.738 \\
Mediana & 9.209 & 11.710 & 20.170 \\
Mínimo & $(42.572)$ & $(1.046)$ & $(25.050)$ \\
Máximo & 634.370 & 4.373 .000 & 459.810 \\
Desvio-padrão & 142.580 & 445.577 & 104.091 \\
\hline Quantidade de empresas & BRA & EUA & \multicolumn{1}{c}{ ING } \\
\hline Menores lucros & 15 & 162 & 24 \\
Maiores lucros & 15 & 161 & 23 \\
\hline \multicolumn{1}{c}{ Total } & $\mathbf{3 0}$ & $\mathbf{3 2 3}$ & \multicolumn{1}{|c}{} \\
\hline
\end{tabular}

Fonte: Dados da pesquisa.

Na Tabela 7 evidencia-se que, a estatística descritiva das empresas industriais dos três países é distinta, não houve semelhança de valores. Quanto à divisão de desempenho, pelo critério de lucro líquido, ao utilizar o critério de seleção da mediana, a amostra ficou dividida de forma equilibrada em dois grupos. Das 400 empresas industriais da amostra, 201 foram classificadas no grupo de menores lucros e 199 no grupo de maiores lucros. Salienta-se que todos os valores foram calculados separadamente por país, evitando prejudicar o valor base por diferenças na quantidade de empresas constantes da amostra para os mesmos.

Murphy (1999) incluiu o lucro da empresa como importante medida de desempenho em sua pesquisa, pois os planos de remuneração de executivos, normalmente possuem esta medida como base para seu 
plano de bônus. Segundo o autor, esta medida gera em torno de 5\% de benefício para o executivo sobre as metas previstas e alcançadas.

Na Tabela 8 apontam-se a estatística descritiva e as características de tamanho das empresas industriais da amostra. A mensuração foi efetivada com base nos ativos totais, descrita em milhares de dólares americanos, medida também adotada no estudo de Jensen e Murphy (1990), Farrel e Whidbee (2003), Mek, Rao e Skousen (2007) e Murphy e Sandino (2010).

Para a definição de empresas menores e maiores utilizou-se o critério de Basiruddin (2011), separando dois grupos de empresas por meio da mediana da amostra, que se constitui numa medida de tendência central.

Tabela 8 - Tamanho das empresas

\begin{tabular}{|c|c|c|c|}
\hline $\begin{array}{l}\text { Estatística descritiva - } \\
\text { Ativos Totais (mi US\$) }\end{array}$ & BRA & EUA & ING \\
\hline Média & 1.418 .334 & 2.127 .924 & 880.735 \\
\hline Mediana & 262.519 & 357.220 & 316.480 \\
\hline Mínimo & 1.202 & 760 & 2.070 \\
\hline Máximo & 16.134 .620 & 61.527 .000 & 5.111 .910 \\
\hline Desvio-padrão & 3.663 .666 & 6.222 .226 & 1.333 .382 \\
\hline Quantidade de empresas & BRA & EUA & ING \\
\hline Empresas menores & 15 & 162 & 24 \\
\hline Empresas maiores & 15 & 161 & 23 \\
\hline Total & 30 & 323 & 47 \\
\hline
\end{tabular}

Fonte: Dados da pesquisa.

Verifica-se na Tabela 8 que a estatística descritiva das empresas industriais dos três países é distinta, não apresentando semelhança de valores. Quanto ao tamanho das empresas, ao utilizar o critério de seleção da mediana, a amostra ficou dividida de forma equilibrada em dois grupos.

O ativo total, base para o cálculo da mediana bem como da estatística descritiva, foi o relativo ao ano de 2010, por ser este o mais atual dentre os anos abrangidos na pesquisa. No total, 201 empresas industriais foram classificadas como sendo menores e 199 como maiores, totalizando 400 empresas. Todos os valores foram calculados separadamente por país, evitando prejudicar o valor base por diferenças na quantidade de empresas constantes da amostra para cada país. 
O tamanho das empresas tem sido utilizado como variável de controle de pesquisas, tais como a de Jensen e Murphy (1990), Murphy (1999), Farrel e Whidbee (2003) e Mek, Rao e Skousen (2007). Segundo Jensen e Murphy (1990) e Murphy (1999), o tamanho da empresa é uma variável relevante na remuneração de executivos. Para Farrel e Whidbee (2003), os CEOs de empresas grandes são mais propensos a experimentar o turnover do que suas contrapartes em empresas pequenas. Mek, Rao e Skousen (2007) destacam que o tamanho da empresa é uma proxy adequada para captar efeitos de assimetria da informação e governança corporativa.

\subsection{POLÍTICAS DE REMUNERAÇÃO - NÍVEL E ESTRUTURA}

A política de remuneração teve como objeto de estudo a diretoria executiva e não apenas o executivo presidente, como descrito até então neste estudo, no item 4.1. Portanto, abrange todos os diretores executivos evidenciados, sejam de produção, financeiro, de operações, de tecnologia, dentre outros cargos denominados pelas empresas industriais pesquisadas.

A política de remuneração seguiu a segregação proposta por Murphy (1999), que designou como nível, o valor total da remuneração, e como estrutura, a divisão em salários, bônus, ações e outras remunerações.

\subsubsection{Empresas Industriais Brasileiras}

Os executivos que atuaram nas empresas industriais brasileiras, no período de 2007 a 2010, tiveram sua remuneração mensurada em reais $(R \$)$ e suas verbas remuneratórias classificadas conforme $\mathrm{o}$ exposto no Quadro 18.

\begin{tabular}{|l|c|c|c|c|}
\hline \multicolumn{1}{|c|}{ CVM } & Salário & Bônus & Ações & Outras \\
\hline Benefícios diretos e indiretos & & & & $\mathrm{x}$ \\
\hline Bônus & & $\mathrm{x}$ & & \\
\hline Outros valores fixos & & $\mathrm{x}$ & & \\
\hline Participação nos resultados & & & & \\
\hline Remuneração baseada em ações & & & $\mathrm{x}$ & \\
\hline Salário ou pró-labore & $\mathrm{x}$ & & & \\
\hline
\end{tabular}

Quadro 18 - Verbas remuneratórias conforme o padrão CVM

Fonte: Dados da pesquisa. 
No Quadro 18 apresenta-se a classificação utilizada pela CVM para a segregação da política de remuneração da diretoria executiva, ou seja, dos executivos das empresas brasileiras pesquisadas. Posto que as verbas remuneratórias tiveram seu padrão definido pela CVM, com campos específicos no Formulário de Referência para evidenciação destas, pelas companhias abertas brasileiras que possuem ações negociadas em bolsas de valores.

Na Tabela 9 revela-se a política de remuneração dos executivos brasileiros, nas perspectivas de nível e de estrutura.

\section{Tabela 9 - Política de remuneração dos executivos brasileiros}

\begin{tabular}{|c|c|c|c|c|}
\hline Executivos Brasileiros & 2007 & 2008 & 2009 & 2010 \\
\hline $\begin{array}{l}\text { Quantidade total de } \\
\text { executivos/ano }\end{array}$ & 148 & 152 & 153 & 154 \\
\hline $\begin{array}{l}\text { Quantidade média } \\
\text { executivos empresa/ano }\end{array}$ & 4,9 & 5,1 & 5,1 & 5,1 \\
\hline Salário total anual - R\$ & 52.510 .674 & 56.853 .851 & 62.580 .450 & 66.464 .814 \\
\hline Bônus total anual - R\$ & 6.772 .168 & 15.213 .334 & 17.091 .481 & 17.815 .584 \\
\hline $\begin{array}{l}\text { Remuneração total anual } \\
\text { em ações - R\$ }\end{array}$ & 806.416 & 150.677 & 283.718 & 567.303 \\
\hline $\begin{array}{l}\text { Outras remunerações - } \\
\text { total anual - } \mathrm{R} \$\end{array}$ & 387.043 & 276.476 & 729.317 & 2.194 .140 \\
\hline Remuneração total - R\$ & 60.476 .301 & 72.494 .338 & 80.684 .966 & 87.041 .841 \\
\hline $\begin{array}{l}\text { \% do salário na } \\
\text { remuneração total }\end{array}$ & 86,8 & 78,4 & 77,6 & 76,4 \\
\hline $\begin{array}{l}\text { \% de bônus na } \\
\text { remuneração total }\end{array}$ & 11,2 & 21,0 & 21,2 & 20,5 \\
\hline $\begin{array}{l}\% \text { de ações na } \\
\text { remuneração total }\end{array}$ & 1,3 & 0,2 & 0,4 & 0,7 \\
\hline $\begin{array}{l}\% \text { de outras na } \\
\text { remuneração total }\end{array}$ & 0,7 & 0,4 & 0,8 & 2,4 \\
\hline $\begin{array}{l}\text { Média anual dos } \\
\text { salários/executivo - R\$ }\end{array}$ & 354.802 & 374.038 & 409.023 & 431.590 \\
\hline $\begin{array}{l}\text { Média anual de } \\
\text { bônus/executivo - R\$ }\end{array}$ & 45.758 & 100.088 & 111.709 & 115.686 \\
\hline $\begin{array}{l}\text { Média anual remun. } \\
\text { ações/executivo - R\$ }\end{array}$ & 5.449 & 991 & 1.854 & 3.684 \\
\hline $\begin{array}{l}\text { Média anual outras } \\
\text { remun./executivo - R\$ }\end{array}$ & 2.615 & 1.819 & 4.767 & 14.248 \\
\hline
\end{tabular}

Fonte: Dados da pesquisa. 
Visualiza-se na Tabela 9 a segregação da política de remuneração dos executivos brasileiros das empresas industriais estudadas, com os valores em reais ( $\mathrm{R} \$$ ) sem centavos. A quantidade média de executivos por ano teve uma variação pequena, pois o total esteve, aproximadamente, entre 148 e 154 executivos nas 30 empresas da amostra, mantendo uma média próxima de 5 executivos por empresa nos quatro anos analisados.

Nota-se que o salário total manteve-se ascendente nos quatro anos, crescendo aproximadamente $27 \%$ de 2007 para 2010. O bônus total também cresceu em todo o período, mas em proporção superior. A remuneração baseada em ações e as outras remunerações reduziram em 2008, e voltaram a crescer em 2009 e 2010.

Observa-se que a variação destas duas últimas verbas remuneratórias teve um comportamento diferente do salário e do bônus total. O salário e as outras remunerações se constituem em uma remuneração acordada no contrato de trabalho entre o executivo e a empresa, que independe do desempenho da empresa ou do próprio executivo. Já o bônus e as ações se constituem em uma remuneração variável, normalmente atrelada ao desempenho da empresa e do próprio executivo.

Quanto ao nível de remuneração total houve um aumento de aproximadamente 44\% no período de 2007 a 2010. Este aumento, superior a $26 \%$ do salário total, foi influenciado, em grande parte, pelo aumento no bônus total de 2007 para 2010.

Quanto à estrutura da remuneração, em média, o salário representou 79,8\%; o bônus $18,5 \%$, a remuneração baseada em ações, $0,7 \%$; e as outras remunerações, $1,0 \%$ da remuneração total.

Em média cada executivo recebeu de salário $\mathrm{R} \$ 392.363,25$ por ano, de bônus $\mathrm{R} \$ 93.310,25$, de ações $\mathrm{R} \$ 2.531,00$ e de outras remunerações $\mathrm{R} \$ 5.862,25$, perfazendo um total médio anual de $\mathrm{R} \$$ $494.066,75$, que corresponde a $\mathrm{R} \$ 41.172,23$ por mês.

\subsubsection{Empresas Industriais Estadunidenses}

Os executivos que atuaram nas empresas industriais estadunidenses, no período de 2007 a 2010, tiveram sua remuneração expressa em dólares americanos (US\$) e suas verbas remuneratórias classificadas conforme o exposto no Quadro 19. 


\begin{tabular}{|l|l|l|l|l|}
\hline \multicolumn{1}{|c|}{ SEC } & Salário & Bônus & Ações & Outras \\
\hline $\begin{array}{l}\text { All other compensation (todas as outras } \\
\text { remunerações) }\end{array}$ & & & & $\mathrm{x}$ \\
\hline Bonus (bônus) & & $\mathrm{x}$ & & \\
\hline $\begin{array}{l}\text { Non-equity incentive plan compensation } \\
\text { (incentivos não representativos de ações no } \\
\text { plano de remuneração) }\end{array}$ & & & & \\
\hline Option awards (prêmios de opções) & & & $\mathrm{x}$ & \\
\hline $\begin{array}{l}\text { Pension value and nonqualified deferred } \\
\text { compensation earnings (valores de previdência e } \\
\text { remunerações diferidas não qualificadas) }\end{array}$ & & & & \\
\hline Salary (salário) & $\mathrm{x}$ & & & \\
\hline Stock awards (prêmios de ações) & & & $\mathrm{x}$ & \\
\hline
\end{tabular}

\section{Quadro 19 - Verbas remuneratórias conforme o padrão SEC}

Fonte: Dados da pesquisa.

No Quadro 19 apresenta-se a classificação utilizada para a segregação da política de remuneração dos executivos estadunidenses. As verbas remuneratórias tiveram seu padrão estabelecido pela SEC, que define campos específicos de evidenciação no Formulário DEF $14 \mathrm{~A}, 10 \mathrm{~K}$ ou $20 \mathrm{~F}$ para as companhias estadunidenses que possuem ações negociadas em bolsas de valores daquele país.

$\mathrm{Na}$ Tabela 10 verifica-se a política de remuneração dos executivos estadunidenses, nas perspectivas de nível e de estrutura.

$\mathrm{Na}$ Tabela 10 verifica-se a segregação da política de remuneração dos executivos estadunidenses das empresas industriais estudadas, cujos valores em dólares americanos constam sem centavos. A quantidade total de executivos por ano situou-se entre 1.262 e 1.442 executivos nas 323 empresas da amostra, mantendo uma média próxima de 4 executivos por empresa nos quatro anos analisados.

Constata-se que o salário total cresceu aproximadamente $15 \%$ de 2007 para 2010, se mantendo ascendente nos quatro anos. Já o bônus total e a remuneração em ações oscilaram diferentemente. O bônus total anual diminuiu em 2008 e 2009 e aumentou em 2010. A remuneração baseada em ações reduziu em 2009 e aumentou em 2008 e 2010. A variação destas verbas remuneratórias teve um comportamento diferente do salário total. As outras remunerações totais, compostas pelos demais benefícios pagos aos executivos, incluindo valores pagos relativos à previdência/aposentadoria, diminuiram em 2008 e voltaram a aumentar em 2009 e 2010. 
Tabela 10 - Política de remuneração dos executivos estadunidenses

\begin{tabular}{|c|c|c|c|c|}
\hline $\begin{array}{c}\text { Executivos } \\
\text { Estadunidenses }\end{array}$ & 2007 & 2008 & 2009 & 2010 \\
\hline $\begin{array}{l}\text { Quantidade total } \\
\text { de executivos/ano }\end{array}$ & 1.323 & 1.262 & 1.316 & 1.442 \\
\hline $\begin{array}{l}\text { Quantidade média } \\
\text { executivos } \\
\text { empresa/ano }\end{array}$ & 4,1 & 3,9 & 4,1 & 4,5 \\
\hline $\begin{array}{l}\text { Salário total anual } \\
\text { - US\$ }\end{array}$ & 450.192 .076 & 456.043 .718 & 484.157 .442 & 517.876 .782 \\
\hline $\begin{array}{l}\text { Bônus total anual - } \\
\text { US\$ }\end{array}$ & 467.486 .705 & 390.976 .004 & 321.839 .176 & 542.753 .876 \\
\hline $\begin{array}{l}\text { Remuneração total } \\
\text { anual em ações - } \\
\text { US\$ }\end{array}$ & 773.592 .373 & 805.075 .898 & 751.238 .150 & 984.474 .585 \\
\hline $\begin{array}{l}\text { Outras } \\
\text { remunerações - } \\
\text { total anual - US\$ }\end{array}$ & 256.106 .918 & 240.972 .624 & 311.903 .455 & 345.983 .426 \\
\hline $\begin{array}{l}\text { Remuneração total } \\
\text { - US\$ }\end{array}$ & 1.947 .378 .072 & 1.893.068.244 & 1.869.138.223 & 2.391.088.669 \\
\hline $\begin{array}{l}\text { \% do salário na } \\
\text { remuneração total }\end{array}$ & 23,1 & 24,1 & 25,9 & 21,7 \\
\hline $\begin{array}{l}\text { \% de bônus na } \\
\text { remuneração total }\end{array}$ & 24,0 & 20,7 & 17,2 & 22,7 \\
\hline $\begin{array}{l}\text { \% de ações na } \\
\text { remuneração total }\end{array}$ & 39,7 & 42,5 & 40,2 & 41,2 \\
\hline $\begin{array}{l}\% \text { de outras na } \\
\text { remuneração total }\end{array}$ & 13,2 & 12,7 & 16,7 & 14,4 \\
\hline $\begin{array}{l}\text { Média anual dos } \\
\text { salários/executivo } \\
\text { - US\$ }\end{array}$ & 340.281 & 361.366 & 367.901 & 359.138 \\
\hline $\begin{array}{l}\text { Média anual de } \\
\text { bônus/executivo - } \\
\text { US\$ }\end{array}$ & 353.354 & 309.807 & 244.559 & 376.390 \\
\hline $\begin{array}{l}\text { Média anual de } \\
\text { ações/executivo - } \\
\text { US\$ }\end{array}$ & 584.726 & 637.937 & 570.850 & 682.715 \\
\hline $\begin{array}{l}\text { Média anual de } \\
\text { outras/executivo - } \\
\text { US\$ }\end{array}$ & 193.580 & 190.945 & 237.009 & 239.933 \\
\hline
\end{tabular}

Fonte: Dados da pesquisa.

Conforme descrito na Tabela 10, quanto ao nível de remuneração total houve um aumento de aproximadamente $23 \%$ no 
período de 2007 a 2010, aumento percentual mais elevado do que o do salário total.

Quanto à estrutura da remuneração, em média o salário representou aproximadamente $23,7 \%$, o bônus $21,1 \%$, a remuneração baseada em ações $40,9 \%$ e as outras remunerações $14,3 \%$ da remuneração total.

Em média cada executivo recebeu de salário US\$ 357.171,50 por ano, de bônus US\$ 321.027,50, de ações US\$ 619.057,00 e de outras remunerações US\$215.366,75, perfazendo um total médio anual de US\$1.512.262,75, que corresponde a US\$126.051,90 por mês.

\subsubsection{Empresas Industriais Inglesas}

Os executivos que atuaram nas empresas industriais inglesas, no período de 2007 a 2010, tiveram sua remuneração mensurada em libras esterlinas ( $£$ ), moeda oficial da Inglaterra, e suas verbas remuneratórias classificadas conforme o exposto no Quadro 20.

\begin{tabular}{|l|c|c|c|c|}
\hline \multicolumn{1}{|c|}{ Empresas Inglesas } & Salário & Bônus & Ações & Outras \\
\hline $\begin{array}{l}\text { All benefits in kind (todos benefícios em } \\
\text { espécie) }\end{array}$ & & & & $\mathrm{x}$ \\
\hline $\begin{array}{l}\text { Annual cash incentive (incentivo anual em } \\
\text { dinheiro) }\end{array}$ & & $\mathrm{x}$ & & \\
\hline $\begin{array}{l}\text { Bonus and pension allowance waived } \\
\text { (bônus e subsídios de previdência pagos) }\end{array}$ & & $\mathrm{x}$ & & \\
\hline Bonus discritionary (bônus discricionário) & & $\mathrm{x}$ & & \\
\hline $\begin{array}{l}\text { Bonuses paid em cash (bônus pago em } \\
\text { dinheiro) }\end{array}$ & & & & \\
\hline $\begin{array}{l}\text { Bonuses paid em shares (bônus pago em } \\
\text { ações) }\end{array}$ & & & $\mathrm{x}$ & \\
\hline Cash (dinheiro) & $\mathrm{x}$ & & & \\
\hline $\begin{array}{l}\text { Cash in lieu of pension (valor pago em } \\
\text { dinheiro equivalente a previdência) }\end{array}$ & $\mathrm{x}$ & & & \\
\hline $\begin{array}{l}\text { Compensation for loss office or employee } \\
\text { (indenização rescisória) }\end{array}$ & $\mathrm{x}$ & & & \\
\hline $\begin{array}{l}\text { Employee profit sharing scheme } \\
\text { (distribuição de lucros a funcionários) }\end{array}$ & & $\mathrm{x}$ & & \\
\hline Fees (restituição de impostos) & $\mathrm{x}$ & & & \\
\hline $\begin{array}{l}\text { Increase in accruded pension during the } \\
\text { year (complemento de previdência) }\end{array}$ & & & & $\mathrm{x}$ \\
\hline $\begin{array}{l}\text { Pension contribution (contribuição de } \\
\text { previdência) }\end{array}$ & & & & $\mathrm{x}$ \\
\hline
\end{tabular}




\begin{tabular}{|c|c|c|c|}
\hline Salary (salário) & $\mathrm{x}$ & & \\
\hline $\begin{array}{l}\text { Share based payments (remuneração em } \\
\text { ações) }\end{array}$ & & $\mathrm{X}$ & \\
\hline $\begin{array}{l}\text { Sums by way of taxable allowances } \\
\text { (restituição de tributos pagos) }\end{array}$ & $\mathrm{x}$ & & \\
\hline $\begin{array}{l}\text { Suplementary allowance (complemento de } \\
\text { remuneração) }\end{array}$ & & & $\mathrm{X}$ \\
\hline Termination payment (verbas rescisórias) & $\mathrm{x}$ & & \\
\hline $\begin{array}{l}\text { Total accrued annual pension (valor de } \\
\text { previdência pago no ano) }\end{array}$ & & & $\mathrm{X}$ \\
\hline $\begin{array}{l}\text { Welfare (bem estar = veículo, aluguel de } \\
\text { imóvel, secretária, motorista, telefone e etc.) }\end{array}$ & & & $\mathrm{X}$ \\
\hline
\end{tabular}

Quadro 20 - Verbas remuneratórias dos executivos ingleses

Fonte: Dados da pesquisa.

Nota-se no Quadro 20 que a política de remuneração dos executivos ingleses teve suas verbas remuneratórias segregadas em salário, bônus, ações e outras remunerações. As colunas salário e as outras abrangeram a maior parte das rubricas de remuneração nas empresas inglesas.

$\mathrm{Na}$ Tabela 11 apresenta-se a política de remuneração dos executivos ingleses, nas perspectivas de nível e de estrutura. Pela mesma observa-se a segregação da política de remuneração dos executivos ingleses das empresas industriais estudadas, cujos valores em libras esterlinas apresentam-se sem centavos. A quantidade total de executivos por ano esteve entre 167 e 179 executivos nas 47 empresas da amostra, mantendo uma média próxima de 4 executivos por empresa nos quatro anos analisados.

Verifica-se que o salário total cresceu aproximadamente $13 \%$ de 2007 para 2010, se mantendo ascendente nos quatro anos. Já o bônus total e a remuneração em ações oscilaram diferentemente. O bônus total anual diminuiu em 2009 e aumentou em 2008 e 2010 e a remuneração baseada em ações reduziu em 2008, 2009 e 2010. Portanto, a variação destas verbas remuneratórias teve um comportamento diferente do salário total.

As outras remunerações totais, compostas pelos demais benefícios pagos aos executivos, inclusive valores relativos às contribuições para previdência ou aos planos privados de aposentadoria, aumentaram em 2008 e reduziram em 2009 e 2010. 
Tabela 11 - Política de remuneração dos executivos ingleses

\begin{tabular}{|c|c|c|c|c|}
\hline Executivos Ingleses & 2007 & 2008 & 2009 & 2010 \\
\hline $\begin{array}{l}\text { Quantidade total de } \\
\text { executivos/ano }\end{array}$ & 179 & 179 & 168 & 167 \\
\hline $\begin{array}{l}\text { Quantidade média de } \\
\text { executivos empresa/ano }\end{array}$ & 3,8 & 3,8 & 3,6 & 3,6 \\
\hline Salário total anual - $£ \$$ & 31.505 .958 & 33.840 .392 & 34.817 .655 & 35.673 .727 \\
\hline Bônus total anual - $£ \$$ & 18.249 .033 & 19.481 .302 & 14.385 .804 & 22.109 .258 \\
\hline $\begin{array}{l}\text { Remuneração total anual } \\
\text { em ações - } £ \$\end{array}$ & 266.000 & 8.000 & 13.000 & 79.000 \\
\hline $\begin{array}{l}\text { Outras remunerações - } \\
\text { total anual - } £ \$\end{array}$ & 5.605 .360 & 6.169 .993 & 5.616 .121 & 5.162 .577 \\
\hline Remuneração total - $£ \$$ & 55.626 .351 & 59.499 .687 & 54.832 .580 & 63.024 .562 \\
\hline $\begin{array}{l}\text { \% do salário na } \\
\text { remuneração total }\end{array}$ & 56,6 & 56,9 & 63,5 & 56,6 \\
\hline $\begin{array}{l}\text { \% de bônus na } \\
\text { remuneração total }\end{array}$ & 32,8 & 32,7 & 26,2 & 35,1 \\
\hline $\begin{array}{l}\% \text { de ações na } \\
\text { remuneração total }\end{array}$ & 0,5 & 0,0 & 0,0 & 0,1 \\
\hline $\begin{array}{l}\text { \% de outras na } \\
\text { remuneração total }\end{array}$ & 10,1 & 10,4 & 10,3 & 8,2 \\
\hline $\begin{array}{l}\text { Média anual dos } \\
\text { salários/executivo - } £ \$\end{array}$ & 176.011 & 189.052 & 207.248 & 213.615 \\
\hline $\begin{array}{l}\text { Média anual de } \\
\text { bônus/executivo - £\$ }\end{array}$ & 101.950 & 108.834 & 85.630 & 132.391 \\
\hline $\begin{array}{l}\text { Média anual de } \\
\text { ações/executivo - } £ \$\end{array}$ & 1.486 & 45 & 77 & 473 \\
\hline $\begin{array}{l}\text { Média anual de outras } \\
\text { rem./executivo - } £ \$\end{array}$ & 31.315 & 34.469 & 33.429 & 30.914 \\
\hline
\end{tabular}

Fonte: Dados da pesquisa.

Quanto ao nível de remuneração total descrito na Tabela 11, houve um aumento de aproximadamente 13\% no período de 2007 a 2010. Mesmo havendo aumento percentual maior em todo o período no salário, os demais componentes da remuneração oscilaram de forma que a variação se manteve no mesmo percentual do salário total.

Quanto à estrutura da remuneração, em média o salário representou aproximadamente $58,4 \%$, o bônus $31,7 \%$, a remuneração baseada em ações $0,1 \%$ e as outras remunerações $9,8 \%$ da remuneração total.

Conforme descrito no início desta seção, a remuneração dos executivos ingleses está descrita na moeda original dos pais, ou seja, 
libras esterlinas $(£ \$)$. Em média cada executivo recebeu de salário $£ \$$ $153.981,50$ por ano, de bônus $£ \$ 107.201,25$, de ações $£ \$ 520,25$ e de outras remunerações $£ \$ 32.531,75$, perfazendo um total médio anual de $£ \$ 294.234,75$, que corresponde a $£ \$ 24.519,56$ por mês.

\subsubsection{Análise conjunta do BRA, EUA e ING para a Política de Remuneração dos executivos nas Perspectivas de Nível e Estrutura}

Comparando-se as verbas remuneratórias dos executivos brasileiros, estadunidenses e ingleses, respectivamente, nota-se que há uma quantidade maior de denominações nas verbas remuneratórias dos executivos ingleses. Este fato se deve à falta de padronização da evidenciação da remuneração dos executivos da Inglaterra, situação diferente da apresentada pelo Brasil e pelos Estados Unidos da América, que possuem, regulamentações estabelecidas pela CVM e SEC, respectivamente. Talvez essa padronização possa contribuir para estimular as empresas inglesas a evidenciarem mais informações a respeito de seus executivos.

Comparando-se a segregação da política de remuneração dos executivos brasileiros, estadunidenses e ingleses, apresentada nas Tabelas 9, 10 e 11, mesmo havendo variações cambiais entre as moedas de cada país, é possível observar semelhanças e diferenças.

A quantidade média anual de executivos que atuou, no período de 2007 a 2010, em cada uma das 400 empresas industriais analisadas nos três países foi semelhante, variando entre 4 e 5 executivos. Nas empresas dos Estados Unidos da América e da Inglaterra houve 4 e para as empresas brasileiras 5 executivos. Este fato indica semelhança na estrutura da diretoria executiva para o setor industrial dos três países.

O salário total obteve crescimento percentual nos três países. Em torno de $27 \%$ para os executivos brasileiros, $15 \%$ para os estadunidenses e $13 \%$ para os ingleses, no período analisado. Já o bônus total e a remuneração em ações tiveram oscilações diferenciadas nos três países, aumentando e reduzindo em determinado ano, mas de 2007 para 2010, apresentaram crescimento. As outras remunerações mantiveram comportamento semelhante ao do bônus anual nos três países. Nota-se semelhança no comportamento das verbas remuneratórias dos três países.

Quanto ao nível de remuneração total, no período de 2007 a 2010, houve um aumento de aproximadamente $44 \%$ para os executivos brasileiros, $23 \%$ para os estadunidenses e $13 \%$ para os ingleses. Por meio destes percentuais, nota-se que os executivos brasileiros tiveram 
um aumento muito superior aos outros dois países. Aumento esse influenciado pelo comportamento no bônus anual de 2007 para 2010.

Quanto à estrutura da remuneração, não se verifica semelhança na política de remuneração dos executivos brasileiros, estadunidenses e ingleses. A exceção fica por conta da remuneração baseada em ações dos brasileiros e ingleses, que representam na remuneração deste menos de $1 \%$ da remuneração total, ao contrário dos estadunidenses que tiveram, em média, 40,9\% de sua remuneração nesta modalidade de pagamento. O salário representou a maior parte da remuneração total para os brasileiros, com $79,8 \%$, em segundo lugar para os ingleses, com $58,4 \%$, e em terceiro lugar para os estadunidenses, com $23,7 \%$. O bônus anual foi mais relevante em termos da estrutura da remuneração dos executivos ingleses, com 31,7\%, em segundo lugar para os estadunidenses, com $21,1 \%$, e em terceiro lugar para os brasileiros, com $18,5 \%$. Por fim, as outras remunerações representaram $14,3 \%$ da remuneração total para os executivos estadunidenses, $9,8 \%$ para os ingleses e $1 \%$ para os brasileiros.

A remuneração total dos três países também não teve comportamento semelhante, se comparadas as médias mensais, ou seja, se considerada a cotação comercial em 31 de dezembro de 2010 de 1 dólar americano a $\mathrm{R} \$ 1,667$ e 1 libra esterlina a $\mathrm{R} \$ 2,228$, a remuneração média mensal dos executivos brasileiros foi de $\mathrm{R} \$$ 41.172,23, a dos ingleses R\$ 54.629,58 e dos estadunidenses R\$ 210.128,51. Nota-se que a remuneração dos executivos brasileiros é a menor e que a dos estadunidenses se destaca em uma quantia muito superior aos demais.

Quanto ao nível de remuneração, a pesquisa de Murphy (1999) demonstrou que dentre os 23 países estudados, incluindo o Brasil, os Estados Unidos da América e a Inglaterra, os Estados Unidos foi a nação que melhor remunerou seus executivos, pois obteve o maior nível de remuneração na pesquisa realizada pelo autor. Entretanto, a posição dos países foi diferente desta pesquisa, pois a remuneração dos executivos estadunidenses na pesquisa de Murphy (1999) foi de, aproximadamente, $29 \%$ superior a dos brasileiros e $84 \%$ superior a dos ingleses. Nesta pesquisa, a remuneração dos executivos estadunidenses foi de, aproximadamente, $284 \%$ superior a dos ingleses e $410 \%$ superior a dos brasileiros. Observa-se que de 1999 para 2010 os executivos estadunidenses e os ingleses das empresas industriais analisadas obtiveram benefícios na sua remuneração, e o inverso ocorreu com os executivos brasileiros. 
Quanto à estrutura de remuneração, Murphy (1999) destacou em sua pesquisa que o salário representava, na época, $57 \%$ da remuneração total dos executivos ingleses, 50\% dos brasileiros e $41 \%$ dos ingleses. O bônus representava $20 \%$ para os executivos estadunidenses, $8 \%$ para os ingleses e $5,7 \%$ para os brasileiros. A remuneração em ações representava $29 \%$ da remuneração total dos executivos estadunidenses, $16 \%$ dos ingleses e $11,5 \%$ para os brasileiros. Nesta pesquisa, comparando-se os resultados da pesquisa de Murphy (1999), verifica-se que estruturalmente: a) o salário dos executivos brasileiros e ingleses aumentou em termos percentuais e dos estadunidenses diminuiu; b) a remuneração em bônus aumentou para os três países; c) a remuneração baseada em ações reduziu-se para os executivos brasileiros e ingleses e aumentou para os estadunidenses.

\subsection{NÍVEIS DE GERENCIAMENTO DE RESULTADOS NAS ATIVIDADES OPERACIONAIS}

Nesta seção expõe-se a análise do gerenciamento de resultados a partir das atividades operacionais, despesas com vendas, gerais e administrativas, despesas com P\&D e o nível de produção das empresas industriais brasileiras, estadunidenses e inglesas. Todos os valores relativos ao gerenciamento de resultados se encontram descritos em milhares de dólares norte-americanos, pois os dados contábeis das empresas industriais brasileiras tiveram seus valores transformados para o dólar mensal de dezembro de cada ano, sendo de: $\mathrm{R} \$ 2,18$ em 2005; $\mathrm{R} \$ 2,15$ em 2006; R\$ 1,77 em 2007; R\$ 2,30 em 2008; R\$ 1,72 em 2009; R\$ 1,72 em 2010.

\subsubsection{Empresas Industriais Brasileiras}

Apresenta-se em alíneas a análise do gerenciamento de resultados por atividades operacionais. Primeiramente, expõem-se os valores para as despesas com vendas, gerais e administrativas; após para as despesas com pesquisa e desenvolvimento; e, por último, para os níveis de produção.

\section{a) GRAO DVGA - Brasil}

Conforme o modelo de Anderson, Banker e Janakiraman (2003), para a estimação do gerenciamento de resultados por meio de despesas com vendas, gerais e administrativas são necessários os valores 
de vendas e das despesas em questão. A estatística descritiva destes valores está apresentada na Tabela 12.

Tabela 12 - Subvariáveis do modelo GRAO DVGA - Brasil

\begin{tabular}{|c|c|c|c|c|}
\hline Estat & 2007 & 2008 & 2009 & 2010 \\
\hline Médi & 447,900 & 485,242 & 814,896 & $1,092,242$ \\
\hline $\begin{array}{l}\text { Média } \\
\text { venda }\end{array}$ & 32,460 & 27,303 & 40,410 & 48,923 \\
\hline $\begin{array}{l}\% \text { das c } \\
\text { gerais e }\end{array}$ & 7,2 & 5,6 & 5,0 & 4,5 \\
\hline Desvio-pa & 849,967 & $1,043,927$ & $1,960,494$ & $2,863,370$ \\
\hline $\begin{array}{l}\text { Desvi } \\
\text { com v }\end{array}$ & 83,846 & 61,204 & 83,979 & 100,6 \\
\hline Mínin & 3 & 1,949 & 1,976 & 2,109 \\
\hline $\begin{array}{l}\text { Mín } \\
\text { ven }\end{array}$ & 4 & 317 & 17 & 1,2 \\
\hline Máximo das & $3,747,663$ & $4,953,491$ & $9,247,544$ & $13,186,775$ \\
\hline $\begin{array}{l}\text { Máximo das despesas ca } \\
\text { vendas, gerais e adm. }\end{array}$ & 83,846 & 61,204 & 83,979 & 100,671 \\
\hline
\end{tabular}

Fonte: Dados da pesquisa.

Na Tabela 12 relacionam-se os valores das subvariáveis do modelo de gerenciamento de resultados por atividades operacionais das empresas brasileiras analisadas, especificamente de despesas com vendas, gerais e administrativas. É possível depreender desta que a média de vendas anual obteve um crescimento em todo o período, apresentando um crescimento de aproximadamente 144\% de 2007 para 2010. As despesas com vendas, gerais e administrativas diminuíram em 2008 e aumentaram em 2009 e 2010. O percentual das despesas em relação às vendas médias situou-se entre $4,5 \%$ e $7,2 \%$, se mantendo decrescente em todo o período.

O desvio-padrão, que mede a dispersão e/ou variabilidade em torno da média obtida, demonstrou alta dispersão em relação à média de vendas e de despesas com vendas, gerais e administrativas. Com relação ao valor mínimo das vendas constantes na amostra de empresas industriais brasileiras, nota-se que não alcançou $10 \%$ da média nos quatro anos. Por outro lado, o valor máximo esteve, nos quatro anos, muito superior à média. O valor mínimo das despesas com vendas, gerais e administrativas acompanhou o comportamento do mínimo das vendas, a exceção foi para o ano de 2007 em que alcançou 10,2\%. O 
valor máximo apresentou-se entre 105,7\% e 158,3\% superior à média nos quatro anos.

De posse desses dados, foi possível aplicar o modelo de mensuração do gerenciamento de resultados por atividades operacionais, especificamente despesas com vendas, gerais e administrativas. $\mathrm{Na}$ Tabela 13 evidencia-se os coeficientes de saída do modelo de regressão aplicado aos dados das empresas industriais brasileiras.

Tabela 13 - Coeficientes do modelo GRAO DVGA - Brasil

\begin{tabular}{l|c|c|c|c|c|c|c|c}
\hline \multirow{2}{*}{ Modelo } & \multicolumn{2}{|c|}{2007} & \multicolumn{2}{c|}{$\mathbf{2 0 0 8}$} & \multicolumn{2}{c|}{2009} & \multicolumn{2}{c}{2010} \\
\cline { 2 - 9 } & Coef. & $\begin{array}{c}\boldsymbol{p}- \\
\text { value }\end{array}$ & Coef. & $\begin{array}{c}\boldsymbol{p} \text { - } \\
\text { value }\end{array}$ & Coef. & $\begin{array}{c}\boldsymbol{p} \text { - } \\
\text { value }\end{array}$ & Coef. & $\begin{array}{c}\boldsymbol{p} \text { - } \\
\text { value }\end{array}$ \\
\hline$\alpha_{1}$ & 0,043 & 0,214 & $-0,113$ & 0,000 & 0,097 & 0,031 & 0,121 & 0,104 \\
$\alpha_{2}$ & 0,498 & 0,115 & 0,928 & 0,033 & 0,386 & 0,154 & 0,431 & 0,503 \\
$\alpha_{3}$ & $-1,151$ & 0,093 & $-0,503$ & 0,036 & 5,557 & 0,001 & 2,291 & 0,343 \\
$\alpha_{4}$ & 0,963 & 0,076 & 0,452 & 0,050 & 0,779 & 0,133 & $-0,514$ & 0,235 \\
$\alpha_{5}$ & $-0,524$ & 0,738 & $-0,808$ & 0,123 & - & 0,345 & $-3,112$ & 0,237 \\
$\mathrm{R}^{2}$ Ajustado & 0,352 & - & 0,557 & - & 0,542 & - & 0,148 & - \\
Sig. & 0,004 & - & 0,000 & - & 0,000 & - & 0,091 & - \\
$\mathrm{N}^{\mathbf{o}}$ de & 30 & - & 30 & - & 30 & - & 30 & - \\
observações & 30 & - & &
\end{tabular}

Fonte: Dados da pesquisa.

Na Tabela 13 visualizam-se os coeficientes de saída do modelo de regressão de Anderson, Banker e Janakiraman (2003). De acordo com estes autores, também por Zang (2005) e Cardoso e Martinez (2006), espera-se que os coeficientes $\alpha_{2}$ e $\alpha_{4}$ sejam positivos, pois as alterações nas despesas com vendas, gerais e administrativas normalmente acompanham as vendas. No caso desta pesquisa, esse fato não ocorreu no ano de 2010, ou seja, os demais satisfizeram a condição simultânea de ambas as variáveis. Pode-se inferir que para o ano de 2007, 2008 e 2009 as despesas acompanharam o nível de vendas, mas com pequeno declínio. Cardoso e Martinez (2006) mencionam que se espera que o coeficiente $\alpha_{3}$ seja negativo, indicando que as despesas com vendas, gerais e administrativas tendem a permanecer constantes no curto prazo. No caso deste estudo, este fato ocorreu apenas em 2007 e 2008. Esta constatação pode ser confirmada pela visualização da 
Tabela 12, que demonstrou pequena variação no valor das despesas com vendas, gerais e administrativas de 2007 para 2008.

Por fim, o coeficiente de saída da regressão esperado para $\alpha_{5}$, segundo Anderson, Banker e Janakiraman (2003), Zang (2005) e Cardoso e Martinez (2006) deve ser positivo, refletindo reversões das despesas com vendas, gerais e administrativas no longo prazo. Para os resultados desta pesquisa esse fato não ocorreu. Verifica-se na Tabela 12 que o percentual médio anual das despesas reduziu de 2007 para 2010. Entretanto, é preciso se ter o horizonte temporal de curto e longo prazo para confirmar esta constatação.

$\mathrm{O}$ valor do $\mathrm{R}^{2}$ ajustado apresenta-se fraco, ou seja, abaixo de 0,75 em todo o período analisado, evidenciando que o poder explicativo do modelo para esta amostra foi baixo, apenas os anos de 2008 e 2009 apresentaram maior poder de explicação com $55,7 \%$ e $54,2 \%$, respectivamente. Conforme Fávero et al. (2009, p. 368), o valor do $\mathrm{R}^{2}$ ajustado "baixo é resultante de uma elevada dispersão dos pontos em torno da reta de regressão".

Os resultados do teste de significância das regressões foram confirmados para os anos de 2007, 2008 e 2009, pois a significância foi inferior a 0,05. Com relação aos coeficientes das variáveis, alguns apresentaram-se significativos em 2008 e 2009, sendo que no total foram analisadas 120 observações.

A partir dos coeficientes gerados no modelo de Anderson, Banker e Janakiraman (2003) para as cinco variáveis, foi possível realizar a mensuração do gerenciamento de resultados, por meio de atividades operacionais, despesas com vendas, gerais e administrativas. $\mathrm{Na}$ Tabela 14 apresenta-se a estatística descritiva dos valores encontrados para as empresas industriais brasileiras no período analisado.

Tabela 14 - Estatística descritiva do GRAO DVGA - Brasil

\begin{tabular}{l|c|r|r|r}
\hline $\begin{array}{l}\text { GRAO } \\
\text { DVGA }\end{array}$ & $\mathbf{2 0 0 7}$ & $\mathbf{2 0 0 8}$ & $\mathbf{2 0 0 9}$ & $\mathbf{2 0 1 0}$ \\
\hline Média & $-0,000322980$ & 0,000234528 & $-0,000270532$ & 0,000343187 \\
Desvio- & 0,086890038 & 0,060858792 & 0,098416452 & 0,167216693 \\
padrão & $-0,252274522$ & $-0,158044757$ & $-0,297426657$ & $-0,188562086$ \\
Mínimo & 0,280486463 & 0,123340293 & 0,286683326 & 0,709203540 \\
Máximo & \multicolumn{4}{|c}{} \\
\hline
\end{tabular}

Fonte: Dados da pesquisa. 
Observa-se na Tabela 14 que o maior valor de gerenciamento de resultados por meio das despesas com vendas gerais e administrativas foi de 0,709203540 em 2010, o menor foi de -0,297426657 em 2009 e a maior média de 0,000343187 em 2010. Cabe ressaltar que o modelo foi significativo para os anos de 2007, 2008 e 2009, confirmando o gerenciamento de resultados por atividades operacionais nas despesas com vendas, gerais e administrativas, nesse período para as empresas industriais brasileiras.

b) GRAO P\&D - Brasil

Com relação ao gerenciamento de resultados por meio de atividades operacionais, especificamente, despesas com pesquisa e desenvolvimento, não foi possível estimar para esta amostra. Ao se coletar as subvariáveis do modelo de Gunny (2005), a redução da amostra excluiu a possibilidade de testes estatísticos, para a amostra de empresas industriais brasileiras, devido à redução da amostra inicial.

c) GRAO NP - Brasil

Segundo o modelo de Roychowdhury (2005), para a estimação do gerenciamento de resultados por meio dos níveis de produção são necessários os valores das vendas, dos custos dos produtos vendidos, dos estoques e dos ativos totais.

A estatística descritiva destes valores é evidenciada na Tabela 15 , em que se excluíram as vendas, uma vez que os respectivos valores já foram expostos na Tabela 12. A estatística descritiva apresentada é relativa as subvariáveis do modelo de regressão para as 30 empresas industriais brasileiras da amostra.

A média anual de estoques se manteve crescente entre 2007 e 2009, e estável de 2009 para 2010, apresentando um crescimento aproximado de $94 \%$ de 2007 para 2010. Os ativos totais e os custos de produtos vendidos se mantiveram crescentes em todo o período. $\mathrm{O}$ custo de produtos vendidos teve um aumento aproximado de 62\% de 2007 para 2010.

O desvio padrão dos estoques, dos ativos e dos custos dos produtos vendidos manteve alta dispersão nos quatro anos analisados, com valores acima da média. Os estoques mínimos mantiveram-se inferiores a média em todo período, representando menos de 1\%. Já os máximos apresentaram-se muito superiores à média. Por fim, os 
mínimos e os máximos dos ativos totais e dos custos dos produtos vendidos tiveram comportamento semelhante ao dos estoques.

Tabela 15 - Subvariáveis do modelo GRAO NP - Brasil

\begin{tabular}{|c|c|c|c|c|}
\hline Esta & 2007 & 2008 & 2009 & 2010 \\
\hline Médi &, 139 & 91,686 & 149,387 & 149,484 \\
\hline Méd & 6,293 & 558,708 & $1,080,378$ & $1,418,334$ \\
\hline $\begin{array}{l}\text { Média } \\
\text { produt }\end{array}$ & 301,166 & 333,812 & 586,816 & 789,475 \\
\hline Desvio-padrão dos estoques & 130,903 & 182,247 & 369,665 & 322,789 \\
\hline $\begin{array}{l}\text { De: } \\
\text { tot: }\end{array}$ & 827,531 & $1,116,363$ & $2,902,658$ & $3,663,666$ \\
\hline $\begin{array}{l}\text { Desvio-padrão dos custos } \\
\text { de produtos vendidos }\end{array}$ & 564,242 & 764,213 & $1,518,037$ & $2,207,725$ \\
\hline Mínimo d & 25 & 25 & 28 & 16 \\
\hline Míni & 1,467 & 0,914 & 1,238 & 1,202 \\
\hline $\begin{array}{l}\text { Míni } \\
\text { prod }\end{array}$ & 1,843 & 1,549 & 1,464 & 1,742 \\
\hline Máximo d & 494,288 & 734,346 & $1,803,095$ & $1,307,741$ \\
\hline Máxi & $3,696,786$ & $4,878,064$ & $14,950,190$ & $16,134,620$ \\
\hline $\begin{array}{l}\text { Máximo dos custos de } \\
\text { produtos vendidos }\end{array}$ & $2,689,315$ & $3,753,979$ & $7,134,075$ & $9,855,321$ \\
\hline
\end{tabular}

Fonte: Dados da pesquisa.

Na Tabela 16 mostram-se os coeficientes de saída do modelo de regressão aplicado aos dados das empresas industriais brasileiras.

Segundo Roychowdhury (2005) e Cardoso e Martinez (2006), é esperado que todos os coeficientes sejam positivos, pois quanto maior as vendas, maior a produção. Coeficientes positivos indicam maior probabilidade de gerenciamento pelas empresas para aumentar seus resultados do período, para coeficientes negativos o raciocínio é inverso.

Para a amostra de empresas brasileiras, conforme a Tabela 16, grande parte dos coeficientes são positivos. Entretanto, o modelo não apresentou os mesmos sinais em cada ano. Assim, não se pode inferir que houve prática de income increasing, ou seja, manipulação para aumentar resultados, mas pode ter havido gerenciamento com intuito inverso, pois o modelo foi estatisticamente significativo e teve alto poder de explicação em todo o período analisado, confirmando a prática 
de gerenciamento de resultados por níveis de produção para as empresas industriais brasileiras da amostra.

Tabela 16 - Coeficientes do modelo GRAO NP - Brasil

\begin{tabular}{|c|c|c|c|c|c|c|c|c|}
\hline \multirow[b]{2}{*}{ Modelo } & \multicolumn{2}{|c|}{2007} & \multicolumn{2}{|c|}{2008} & \multicolumn{2}{|c|}{2009} & \multicolumn{2}{|c|}{2010} \\
\hline & Coef. & $\begin{array}{c}p- \\
\text { value }\end{array}$ & Coef. & $\begin{array}{c}p- \\
\text { value }\end{array}$ & Coef. & $\begin{array}{c}p- \\
\text { value }\end{array}$ & Coef. & $\begin{array}{c}p- \\
\text { value }\end{array}$ \\
\hline$\alpha_{1}$ & $-0,008$ & 0,926 & $-0,011$ & 0,869 & 0,018 & 0,886 & $-0,044$ & 0,619 \\
\hline$\alpha_{2}$ & 0,297 & 0,670 & 0,183 & 0,795 & 0,023 & 0,945 & 0,018 & 0,945 \\
\hline$\alpha_{3}$ & 0,723 & 0,000 & 0,739 & 0,000 & 0,786 & 0,000 & 0,85 & 0,000 \\
\hline$\alpha_{4}$ & 0,216 & 0,202 & 0,209 & 0,188 & $-0,169$ & 0,474 & 0,043 & 0,842 \\
\hline$\alpha_{5}$ & $-0,366$ & 0,256 & $-0,077$ & 0,679 & 0,076 & 0,644 & $-0,389$ & 0,097 \\
\hline $\mathrm{R}^{2}$ Ajustado & 0,870 & - & 0,824 & - & 0,763 & - & 0,804 & - \\
\hline Sig. & 0,000 & - & 0,000 & - & 0,000 & - & 0,000 & - \\
\hline $\begin{array}{l}\mathrm{N}^{\mathrm{o}} \text { de } \\
\text { observações }\end{array}$ & 30 & - & 30 & - & 30 & - & 30 & - \\
\hline
\end{tabular}

Fonte: Dados da pesquisa.

Diante dos coeficientes gerados pelo modelo de Roychowdhury (2005) foi possível realizar a mensuração do gerenciamento de resultados, por meio de atividades operacionais, nível de produção e aumento das vendas temporariamente. Na Tabela 17 expõe-se a estatística descritiva dos valores encontrados para as empresas industriais brasileiras no período analisado.

Tabela 17 - Estatística descritiva do GRAO NP - Brasil

\begin{tabular}{l|c|c|c|c}
\hline \multicolumn{1}{c|}{$\mathbf{\text { NRAO }}$} & $\mathbf{2 0 0 7}$ & $\mathbf{2 0 0 8}$ & $\mathbf{2 0 0 9}$ & $\mathbf{2 0 1 0}$ \\
\hline Média & $-0,000544920$ & $-0,000782146$ & 0,000094489 & 0,000259605 \\
Desvio- & 0,169642123 & 0,131624386 & 0,222458712 & 0,158995553 \\
padrão & $-0,402664856$ & $-0,367185961$ & $-0,597105389$ & $-0,429130581$ \\
Mínimo & 0,334440250 & 0,249077259 & 0,381537775 & 0,292773518 \\
Máximo &
\end{tabular}

Fonte: Dados da pesquisa.

Observa-se na Tabela 17 que o maior valor de gerenciamento de resultados por meio do nível de produção foi de 0,381537775, em 2009, e o menor foi de $-0,597105389$ no mesmo ano. A maior média ocorreu 
em 2010 e a menor em 2008. Salienta-se que o modelo confirmou o gerenciamento de resultados por manipulação nos níveis de produção, nos quatro anos, das empresas industriais brasileiras da amostra analisada.

\subsubsection{Empresas Industriais Estadunidenses}

Apresenta-se em alíneas a análise do gerenciamento de resultados por atividades operacionais para as empresas industriais estadunidenses. Primeiramente, expõem-se os valores para as despesas com vendas, gerais e administrativas; após para as despesas com pesquisa e desenvolvimento; e, por último, para os níveis de produção.

a) GRAO DVGA - Estados Unidos

Para estimar o modelo de Anderson, Banker e Janakiraman (2003), de gerenciamento de resultados por meio de despesas com vendas, gerais e administrativas, são necessários os valores de vendas e das despesas em questão. A estatística descritiva destes valores é apresentada na Tabela 18.

Tabela 18 - Subvariáveis do modelo GRAO DVGA - Estados Unidos

\begin{tabular}{l|r|r|r|r}
\hline \multicolumn{1}{c|}{ Estatística descritiva } & \multicolumn{1}{c|}{$\mathbf{2 0 0 7}$} & \multicolumn{1}{c|}{$\mathbf{2 0 0 8}$} & \multicolumn{1}{c|}{$\mathbf{2 0 0 9}$} & \multicolumn{1}{c}{$\mathbf{2 0 1 0}$} \\
\hline $\begin{array}{l}\text { Média das vendas } \\
\text { Média das DVGA }\end{array}$ & $304,015,032$ & $2,158,485$ & $1,761,418$ & $1,934,451$ \\
\% das DVGA / vendas & 15,1 & 326,270 & 295,995 & 316,917 \\
\hline $\begin{array}{l}\text { Desvio-padrão das vendas } \\
\text { Desvio-padrão das } \\
\text { despesas com vendas, } \\
\text { gerais e adm. }\end{array}$ & $5,339,144$ & $5,806,391$ & $4,723,22$ & $5,238,246$ \\
\hline $\begin{array}{l}\text { Mínimo das vendas } \\
\begin{array}{l}\text { Mínimo das despesas com } \\
\text { vendas, gerais e adm. }\end{array}\end{array}$ & 838,884 & 905,967 & 807,271 & 884,532 \\
\hline $\begin{array}{l}\text { Máximo das vendas } \\
\begin{array}{l}\text { Máximo das despesas } \\
\text { com vendas, gerais e } \\
\text { adm. }\end{array}\end{array}$ & $53,920,000$ & $58,043,000$ & $52,425,000$ & $54,207,000$ \\
\hline
\end{tabular}

Fonte: Dados da pesquisa. 
Na Tabela 18 evidenciaram-se os valores das subvariáveis do modelo de gerenciamento de resultados por atividades operacionais das empresas estadunidenses analisadas, especificamente de despesas com vendas, gerais e administrativas. É possível depreender desta que a média de vendas anual obteve um decréscimo de 2007 para 2010. Já as despesas com vendas, gerais e administrativas acompanharam o comportamento das vendas em 2008 e 2009. Por outro lado, o percentual das despesas em relação às vendas médias apresenta-se entre $15,1 \%$ e $16,8 \%$, se mantendo próximo em todo o período.

O desvio-padrão, que mede a dispersão e/ou variabilidade em torno da média obtida, demonstrou uma alta dispersão em relação à média de vendas e de despesas com vendas, gerais e administrativas. Com relação ao valor mínimo das vendas constante na amostra de empresas industriais estadunidenses, nota-se que este foi inferior em relação à média. Por outro lado, o valor máximo apresenta-se elevado em relação à média nos quatro anos. $\mathrm{O}$ valor mínimo das despesas com vendas, gerais e administrativas acompanhou o comportamento do mínimo das vendas. Entretanto, o valor máximo apresenta-se elevado em relação à média nos quatro anos analisados.

Na Tabela 19 verificam-se os coeficientes de saída do modelo de regressão aplicado aos dados das empresas industriais estadunidenses.

Tabela 19 - Coeficientes do modelo GRAO DVGA - Estados Unidos

\begin{tabular}{l|c|c|c|c|c|c|c|c}
\hline \multirow{2}{*}{ Modelo } & \multicolumn{2}{|c|}{$\mathbf{2 0 0 7}$} & \multicolumn{2}{c|}{$\mathbf{2 0 0 8}$} & \multicolumn{2}{c|}{$\mathbf{2 0 0 9}$} & \multicolumn{2}{c}{$\mathbf{2 0 1 0}$} \\
\cline { 2 - 9 } & Coef. & $\begin{array}{c}\boldsymbol{p} \text { - } \\
\text { value }\end{array}$ & Coef. & $\begin{array}{c}\boldsymbol{p} \text { - } \\
\text { value }\end{array}$ & Coef. & $\begin{array}{c}\boldsymbol{p} \text { - } \\
\text { value }\end{array}$ & Coef. & $\begin{array}{c}\boldsymbol{p} \text { - } \\
\text { value }\end{array}$ \\
\hline$\alpha_{1}$ & 0,021 & 0,000 & 0,006 & 0,306 & $-0,014$ & 0,326 & 0,025 & 0,001 \\
$\alpha_{2}$ & 0,402 & 0,000 & 0,344 & 0,000 & 0,576 & 0,026 & 0,413 & 0,000 \\
$\alpha_{3}$ & 0,245 & 0,049 & 0,001 & 0,995 & $-0,232$ & 0,448 & $-0,122$ & 0,205 \\
$\alpha_{4}$ & 0,140 & 0,003 & 0,174 & 0,001 & 0,111 & 0,353 & $-0,245$ & 0,087 \\
$\alpha_{5}$ & $-0,115$ & 0,275 & $-0,21$ & 0,109 & 0,177 & 0,468 & 0,441 & 0,011 \\
$\mathrm{R}^{2}$ Ajustado & 0,363 & - & 0,255 & - & 0,095 & - & 0,235 & - \\
Sig. & 0,000 & - & 0,000 & - & 0,000 & - & 0,000 & - \\
$\mathrm{N}^{\mathbf{o}}$ de & 323 & - & 323 & - & 323 & - & 323 & - \\
observações & 323
\end{tabular}

Fonte: Dados da pesquisa. 
Na Tabela 19 visualizam-se os coeficientes de saída do modelo de regressão de Anderson, Banker e Janakiraman (2003). Conforme estes autores e também Zang (2005) e Cardoso e Martinez (2006), espera-se que os coeficientes $\alpha_{2}$ e $\alpha_{4}$ sejam positivos, pois as alterações nas despesas com vendas, gerais e administrativas normalmente acompanham as vendas. No caso desta pesquisa, esse fato só não ocorreu em 2010, ou seja, satisfazendo a condição simultânea de ambas as variáveis. Pode-se inferir que as despesas se mantiveram estáveis em relação ao nível de vendas. Este fato pode ser confirmado na Tabela 18, pois o percentual das despesas com vendas, gerais e administrativas se manteve praticamente o mesmo, ainda que tenha havido aumento nas vendas e nas despesas.

Anderson, Banker e Janakiraman (2003), Zang (2005) e Cardoso e Martinez (2006) mencionam que se espera que o coeficiente $\alpha_{3}$ seja negativo, indicando que as despesas com vendas, gerais e administrativas tendem a permanecer constantes no curto prazo. No caso deste estudo este fato ocorreu em 2009 e 2010.

$\mathrm{O}$ coeficiente de saída da regressão esperado para $\alpha_{5}$, segundo Anderson, Banker e Janakiraman (2003), Zang (2005) e Cardoso e Martinez (2006), deve ser positivo, refletindo reversões das despesas com vendas, gerais e administrativas no longo prazo. Para os resultados desta pesquisa esse fato ocorreu apenas em 2009 e 2010. Na Tabela 18 verifica-se que o percentual médio anual das despesas aumentou no período analisado, mesmo que as vendas tenham reduzido.

$\mathrm{O}$ valor do $\mathrm{R}^{2}$ ajustado apresentado teve um baixo poder explicativo do modelo nos quatro anos analisados para esta amostra. Em contrapartida, os resultados do teste de significância das regressões foram confirmados para os quatro anos, pois o índice foi inferior a 0,05. Com relação aos coeficientes das variáveis, alguns apresentaram-se significativos no período analisado, sendo que no total foram analisadas 1.292 observações.

Com base nos coeficientes gerados pelo modelo de Anderson, Banker e Janakiraman (2003), foi possível realizar a mensuração do gerenciamento de resultados, por meio de atividades operacionais, despesas com vendas, gerais e administrativas.

$\mathrm{Na}$ Tabela 20 evidencia-se a estatística descritiva dos valores encontrados para as empresas industriais estadunidenses no período analisado. 


Tabela 20 - Estatística descritiva do GRAO DVGA - Estados
Unidos
\begin{tabular}{l|r|r|r|r}
\multicolumn{1}{c}{ GRAO DVGA } & \multicolumn{1}{c|}{$\mathbf{2 0 0 7}$} & \multicolumn{1}{c}{$\mathbf{2 0 0 8}$} & \multicolumn{1}{c}{$\mathbf{2 0 0 9}$} & $\mathbf{2 0 1 0}$ \\
\hline Média & $-0,000073751$ & $-0,000362762$ & $-0,000266408$ & 0,000372902 \\
Desvio-padrão & 0,056224821 & 0,059312609 & 0,063801196 & 0,046603847 \\
Mínimo & $-0,284705585$ & $-0,392239229$ & $-0,263211122$ & $-0,233210032$ \\
Máximo & 0,190014759 & 0,358768666 & 0,474418558 & 0,250003110 \\
\hline
\end{tabular}

Fonte: Dados da pesquisa.

Observa-se na Tabela 20, que o maior valor de gerenciamento de resultados por meio das despesas com vendas gerais e administrativas para as empresas industriais estadunidenses foi de $0,474418558 \mathrm{em}$ 2009, e o menor foi de $-0,392239229$ em 2008. A média se manteve negativa nos três primeiros anos. A menor foi no ano de 2008 e a maior em 2010. O modelo de Anderson, Banker e Janakiraman (2003), aplicado nas empresas industriais estadunidenses da amostra analisada, confirmou o gerenciamento de resultados por manipulação nas despesas com vendas, gerais e administrativas, nos quatro anos.

b) GRAO P\&D - Estados Unidos

Com relação ao gerenciamento de resultados por meio de atividades operacionais, especificamente, despesas com pesquisa e desenvolvimento, não foi possível estimar os valores para esta amostra, pois ao coletar as subvariáveis do modelo de Gunny (2005), a redução da amostra excluiu a possibilidade de testes estatísticos para as empresas industriais brasileiras, devido à redução da amostra inicial, bem como reduziu em torno de $80 \%$ a amostra das empresas estadunidenses.

c) GRAO NP - Estados Unidos

De acordo com o modelo de Roychowdhury (2005), para a estimação do gerenciamento de resultados por meio dos níveis de produção são necessários os valores das vendas, dos custos dos produtos vendidos, dos estoques e dos ativos totais. A estatística descritiva destes valores é evidenciada na Tabela 21, exceto as vendas, cujos valores já foram expostos na Tabela 18. 
Tabela 21 - Subvariáveis do modelo GRAO NP - Estados Unidos

\begin{tabular}{|c|c|c|c|c|}
\hline Estatística descritiva & 2007 & 2008 & 2009 & 2010 \\
\hline Média dos estoques & 271,634 & 294,641 & 254,772 & 291,075 \\
\hline Médi & $1,985,325$ & $2,019,147$ & $1,987,347$ & $2,127,924$ \\
\hline $\begin{array}{l}\text { Média dos custos de } \\
\text { produtos vendidos }\end{array}$ & $1,419,960$ & $1,523,531$ & $1,230,691$ & $1,330,800$ \\
\hline $\begin{array}{l}\text { Desvio-padrão dos } \\
\text { estoques }\end{array}$ & 736,342 & 814,703 & 684,480 & 833,223 \\
\hline $\begin{array}{l}\text { Desvio-padrão dos ativos } \\
\text { totais }\end{array}$ & $5,699,530$ & $5,991,661$ & $5,826,090$ & $6,222,226$ \\
\hline $\begin{array}{l}\text { Desvio-padrão dos custos } \\
\text { de produtos vendidos }\end{array}$ & $3,720,461$ & $4,058,058$ & $3,244,176$ & $3,539,570$ \\
\hline Mínime & 0 & 0 & 0 & 0 \\
\hline Míni & 310 & 200 & 840 & 760 \\
\hline $\begin{array}{l}\text { Mínimo dos } \\
\text { produtos ven }\end{array}$ & 60 & 180 & 0 & 0 \\
\hline Máximo dos estoques & $8,101,000$ & $8,781,000$ & $7,509,000$ & $9,587,000$ \\
\hline Máximo d & $54,579,000$ & $64,471,000$ & $57,324,000$ & $61,527,000$ \\
\hline $\begin{array}{l}\text { Máximo dos custos de } \\
\text { produtos vendidos }\end{array}$ & $38,639,000$ & $41,092,000$ & $37,183,000$ & $37,689,000$ \\
\hline
\end{tabular}

Fonte: Dados da pesquisa.

$\mathrm{Na}$ Tabela 21 evidencia-se a estatística descritiva das subvariáveis do modelo de regressão para as 323 empresas industriais estadunidenses da amostra. A média anual de estoques aumentou em 2008 e 2010 e reduziu em 2009, apresentando um crescimento aproximado de 7,2\% de 2007 para 2010. Os ativos totais aumentaram em 2008 e 2010 e reduziram em 2009. Os custos dos produtos vendidos tiveram redução em 2009 e 2010.

O desvio padrão dos estoques, dos ativos totais e dos custos dos produtos vendidos manteve alta dispersão nos quatro anos analisados. Os estoques mínimos mantiveram-se inferiores a média em todo período, já os máximos apresentaram-se acima da média. Por fim, os mínimos e máximos dos ativos totais e dos custos dos produtos vendidos tiveram comportamento semelhante ao dos estoques.

Na Tabela 22 verificam-se os coeficientes de saída do modelo de regressão aplicado aos dados das empresas industriais estadunidenses. 


\section{Tabela 22 - Coeficientes do modelo GRAO NP - Estados Unidos}

\begin{tabular}{|c|c|c|c|c|c|c|c|c|}
\hline \multirow[b]{2}{*}{ Modelo } & \multicolumn{2}{|c|}{2007} & \multicolumn{2}{|c|}{2008} & \multicolumn{2}{|c|}{2009} & \multicolumn{2}{|c|}{2010} \\
\hline & Coef. & $\begin{array}{c}p- \\
\text { value }\end{array}$ & Coef. & $\begin{array}{c}p- \\
\text { value }\end{array}$ & Coef. & $\begin{array}{c}p- \\
\text { value }\end{array}$ & Coef. & $\begin{array}{c}p- \\
\text { value }\end{array}$ \\
\hline$\alpha_{1}$ & $-0,182$ & 0,000 & $-0,169$ & 0,000 & $-0,095$ & 0,000 & $-0,122$ & 0,000 \\
\hline$\alpha_{2}$ & $-0,386$ & 0,000 & $-0,381$ & 0,000 & $-0,182$ & 0,000 & $-0,585$ & 0,000 \\
\hline$\alpha_{3}$ & 0,856 & 0,000 & 0,859 & 0,000 & 0,756 & 0,000 & 0,785 & 0,000 \\
\hline$\alpha_{4}$ & 0,074 & 0,033 & $-0,032$ & 0,383 & $-0,090$ & 0,001 & 0,016 & 0,655 \\
\hline$\alpha_{5}$ & 0,025 & 0,609 & $-0,016$ & 0,673 & 0,001 & 0,972 & $-0,12$ & 0,000 \\
\hline $\mathrm{R}^{2}$ Ajustado & 0,923 & - & 0,890 & - & 0,844 & - & 0,877 & - \\
\hline Sig. & 0,000 & - & 0,000 & - & 0,000 & - & 0,000 & - \\
\hline $\begin{array}{l}N^{o} \text { de } \\
\text { observações }\end{array}$ & 323 & - & 323 & - & 323 & - & 323 & - \\
\hline
\end{tabular}

Fonte: Dados da pesquisa.

Conforme Roychowdhury (2005) e Cardoso e Martinez (2006), é esperado que todos os coeficientes sejam positivos, pois quanto maior as vendas, maior a produção. Coeficientes positivos indicam maior probabilidade de gerenciamento pelas empresas para aumentar seus resultados do período, e para coeficientes negativos o raciocínio é inverso.

Para a amostra de empresas estadunidenses, conforme evidenciado na Tabela 22, nota-se que $50 \%$ dos coeficientes são positivos. No entanto, simultaneamente os cinco coeficientes não tiveram o mesmo sinal nos quatro anos analisados. Assim, não se pode aceitar a prática de income increasing, ou seja, manipulação para aumentar resultados. No entanto, confirmou-se a prática de gerenciamento de resultados por meio do nível de produção, devido ao valor do $\mathrm{R}^{2}$ ajustado ter apresentado alto poder explicativo do modelo nos quatro anos analisados para esta amostra. Também, pelos resultados do teste de significância das regressões terem sido confirmados para todo o período analisado, sendo inferior a 0,05 . Com relação aos coeficientes das variáveis, a maioria apresentou-se significativo, também para os quatro anos, sendo que no total foram analisadas 1.292 observações.

Conforme os coeficientes obtidos do modelo de Roychowdhury (2005) foi possível realizar a mensuração do gerenciamento de resultados, por meio de atividades operacionais, nível de produção e aumento das vendas temporariamente. Na Tabela 23 expõe-se a 
estatística descritiva dos valores encontrados para as empresas industriais estadunidenses no período analisado.

Tabela 23 - Estatística descritiva do GRAO NP - Estados Unidos

\begin{tabular}{l|c|c|c|c}
\hline \multicolumn{1}{c|}{ GRAO } & $\mathbf{2 0 0 7}$ & $\mathbf{2 0 0 8}$ & $\mathbf{2 0 0 9}$ & $\mathbf{2 0 1 0}$ \\
\hline Média & $-0,000295276$ & $-0,000072465$ & $-0,000729830$ & 0,000452542 \\
Desvio- & 0,160586187 & 0,156965948 & 0,147974599 & 0,170191835 \\
padrão & $-1,030365269$ & $-0,899421329$ & $-0,764067151$ & $-0,788922460$ \\
Mínimo & 0,527801301 & 0,402297250 & 0,681285077 & 0,735571429 \\
Máximo & \multicolumn{4}{|l}{} \\
\hline
\end{tabular}

Fonte: Dados da pesquisa.

Observa-se na Tabela 23 que o maior valor de gerenciamento de resultados por meio do nível de produção foi de 0,735571429, em 2010, e o menor foi de $-0,899421329$, em 2008. A maior média ocorreu em 2010 e a menor em 2009. Ressalta-se que o modelo confirmou que houve gerenciamento de resultados por manipulação nos níveis de produção, nos quatro anos, das empresas industriais estadunidenses da amostra analisada.

\subsubsection{Empresas Industriais Inglesas}

Apresenta-se em alíneas a análise do gerenciamento de resultados por atividades operacionais. Primeiramente, expõem-se os valores para as despesas com vendas, gerais e administrativas; após para as despesas com pesquisa e desenvolvimento; e, por último, para os níveis de produção.

a) GRAO DVGA - Inglaterra

Para estimar o modelo de Anderson, Banker e Janakiraman (2003) de gerenciamento de resultados por meio de despesas com vendas, gerais e administrativas são necessários os valores de vendas e das despesas mencionadas. A estatística descritiva destes valores é evidenciada na Tabela 24. 


\section{Tabela 24 - Subvariáveis do modelo GRAO DVGA - Inglaterra}

\begin{tabular}{|c|c|c|c|c|}
\hline Estatística descritiva & 2007 & 2008 & 2009 & 2010 \\
\hline Média & 837,249 & 807 & 783,092 & 816,229 \\
\hline $\begin{array}{l}\text { Média das despesas com } \\
\text { vendas, gerais e adm. }\end{array}$ & 189,948 & 174,624 & 178,009 & 185,152 \\
\hline $\begin{array}{l}\% \text { das despesas c } \\
\text { vendas, gerais e a } \\
\text { vendas }\end{array}$ & 22,7 & 21,6 & 22,7 & 22,7 \\
\hline Desvio-padrão das vendas & $1,207,182$ & $1,140,228$ & $1,067,633$ & $1,135,615$ \\
\hline $\begin{array}{l}\text { Desvio-padrão das despesas } \\
\text { com vendas, gerais e adm. }\end{array}$ & 302,963 & 270,673 & 271,890 & 281,436 \\
\hline Míni & 110 & 50 & 410 & 40 \\
\hline $\begin{array}{l}\text { Mínir } \\
\text { venda }\end{array}$ & 2,270 & 2,500 & 2,530 & 1,990 \\
\hline Máximo das vendas & $5,024,980$ & $4,598,070$ & $4,417,510$ & $4,337,470$ \\
\hline $\begin{array}{l}\text { Máximo das despesas com } \\
\text { vendas, gerais e adm. }\end{array}$ & $1,446,620$ & $1,374,740$ & $1,376,350$ & $1,320,220$ \\
\hline
\end{tabular}

Fonte: Dados da pesquisa.

$\mathrm{Na}$ Tabela 24 verificam-se os valores das subvariáveis do modelo de gerenciamento de resultados por atividades operacionais das empresas inglesas analisadas, especificamente de despesas com vendas, gerais e administrativas. Depreende-se que a média de vendas anual obteve um decréscimo praticamente em todo o período analisado, apresentando uma recuperação parcial na média de vendas de 2007 para 2010. Já as despesas com vendas, gerais e administrativas acompanharam o comportamento das vendas apenas em 2007. Por outro lado, o percentual das despesas manteve-se na mesma proporção em relação às vendas médias em 2007, 2009 e 2010.

O desvio-padrão, que mede a dispersão e/ou variabilidade em torno da média obtida, demonstrou uma alta dispersão em relação à média de vendas e de despesas com vendas, gerais e administrativas. Com relação ao valor mínimo das vendas da amostra de empresas industriais inglesas, nota-se que este foi inferior em relação à média. Por outro lado, o valor máximo esteve nos quatro anos elevado em relação à média. $\mathrm{O}$ valor mínimo das despesas com vendas, gerais e administrativas acompanhou o comportamento do mínimo das vendas. Entretanto, o valor máximo apresenta-se elevado em relação à média nos quatro anos analisados. 
Na Tabela 25 apresentam-se os coeficientes de saída do modelo de regressão aplicado aos dados das empresas industriais inglesas.

\begin{tabular}{|c|c|c|c|c|c|c|c|c|}
\hline \multirow[b]{2}{*}{ Modelo } & \multicolumn{2}{|c|}{2007} & \multicolumn{2}{|c|}{2008} & \multicolumn{2}{|c|}{2009} & \multicolumn{2}{|c|}{2010} \\
\hline & Coef. & $\begin{array}{c}p- \\
\text { value }\end{array}$ & Coef. & $\begin{array}{c}p- \\
\text { value }\end{array}$ & Coef. & $\begin{array}{c}p- \\
\text { value }\end{array}$ & Coef. & $\begin{array}{c}p- \\
\text { value }\end{array}$ \\
\hline$\alpha_{1}$ & 0,037 & 0,111 & $-0,047$ & 0,007 & 0,029 & 0,067 & $-0,024$ & 0,172 \\
\hline$\alpha_{2}$ & 0,473 & 0,011 & 0,969 & 0,000 & 0,007 & 0,934 & 0,601 & 0,070 \\
\hline$\alpha_{3}$ & $-0,050$ & 0,931 & $-0,791$ & 0,001 & 0,685 & 0,000 & 0,115 & 0,815 \\
\hline$\alpha_{4}$ & $-0,119$ & 0,313 & 0,038 & 0,725 & 0,095 & 0,438 & 0,586 & 0,038 \\
\hline$\alpha_{5}$ & $-0,204$ & 0,458 & $-0,620$ & 0,100 & $-0,116$ & 0,601 & $-0,671$ & 0,141 \\
\hline $\mathrm{R}^{2}$ Ajustado & 0,204 & - & 0,648 & - & 0,427 & - & 0,312 & - \\
\hline Sig. & 0,008 & - & 0,000 & - & 0,000 & - & 0,001 & - \\
\hline $\begin{array}{l}\mathrm{N}^{\circ} \text { de } \\
\text { observacões }\end{array}$ & 47 & - & 47 & - & 47 & - & 47 & - \\
\hline
\end{tabular}

Fonte: Dados da pesquisa.

Na Tabela 25 visualizam-se os coeficientes de saída do modelo de regressão para as 188 observações, referentes às 47 empresas em cada um dos quatro anos. Conforme o esperado para $\alpha_{2}$ e $\alpha_{4}$, ambos os coeficientes foram positivos, simultaneamente em 2008, 2009 e 2010. Isto indica, conforme Anderson, Banker e Janakiraman (2003), Zang (2005) e Cardoso e Martinez (2006), que as alterações nas despesas com vendas, gerais e administrativas acompanharam as vendas. Os mesmos autores mencionam que se espera que o coeficiente $\alpha_{3}$ seja negativo, indicando que as despesas com vendas, gerais e administrativas tendem a permanecer constantes no curto prazo. No caso deste estudo este fato ocorreu em 2007 e 2008.

O coeficiente de saída da regressão esperado para $\alpha_{5}$, segundo Anderson, Banker e Janakiraman (2003), Zang (2005) e Cardoso e Martinez (2006), deve ser positivo, refletindo reversões das despesas com vendas, gerais e administrativas no longo prazo. Para os resultados desta pesquisa esse fato não ocorreu no período analisado.

$\mathrm{O}$ valor do $\mathrm{R}^{2}$ ajustado apresentou baixo poder explicativo do modelo nos quatro anos pesquisados. Os resultados do teste de significância das regressões foram confirmados para os quatro anos analisados, pois a significância foi inferior a 0,05 , com relação aos coeficientes das variáveis, alguns apresentaram-se significativos, 
principalmente no ano de 2008, sendo que no total foram analisadas 188 observações.

De posse dos coeficientes gerados pelo cálculo do modelo de Anderson, Banker e Janakiraman (2003), foi viabilizada a mensuração do gerenciamento de resultados, por meio de atividades operacionais, despesas com vendas, gerais e administrativas. Na Tabela 26 apresentase a estatística descritiva dos valores encontrados para as empresas industriais inglesas no período analisado.

\begin{tabular}{l|c|c|c|c}
\multicolumn{5}{c}{ Tabela 26 - Estatística descritiva do GRAO DVGA - Inglaterra } \\
\hline $\begin{array}{l}\text { GRAO } \\
\text { DVGA }\end{array}$ & $\mathbf{2 0 0 7}$ & $\mathbf{2 0 0 8}$ & $\mathbf{2 0 0 9}$ & $\mathbf{2 0 1 0}$ \\
\hline Média & 0,000189069 & 0,000377584 & $-0,000212992$ & 0,000053837 \\
$\begin{array}{l}\text { Desvio- } \\
\text { padrão }\end{array}$ & 0,097165380 & 0,063196534 & 0,057203577 & 0,080437379 \\
Mínimo & $-0,369505079$ & $-0,177913933$ & $-0,129340631$ & $-0,353919421$ \\
Máximo & 0,299950504 & 0,113189354 & 0,179460911 & 0,108045801 \\
\hline
\end{tabular}

Fonte: Dados da pesquisa.

Observa-se na Tabela 26 que o maior valor de gerenciamento de resultados por meio das despesas com vendas gerais e administrativas foi de 0,299950504, em 2007, e o menor foi de - 0,369505079, no mesmo ano. A maior média foi de 0,000377584 , em 2008, e a menor foi de - 0,000212992, em 2009.

Destaca-se que o modelo confirmou que houve gerenciamento de resultados por manipulação nas despesas com vendas, gerais e administrativas, nos quatro anos, das empresas industriais inglesas da amostra analisada.

c) GRAO P\&D - Inglaterra

Com relação ao gerenciamento de resultados por meio de atividades operacionais, especificamente, despesas com pesquisa e desenvolvimento, não foi possível estimar para esta amostra.

Ao coletar as subvariáveis do modelo de Gunny (2005), a redução da amostra excluiu a possibilidade de realização de testes estatísticos, devido à redução de $90 \%$ da amostra inicial, de empresas industriais inglesas. 
c) GRAO NP - Inglaterra

O modelo de Roychowdhury (2005), para a estimação do gerenciamento de resultados por meio dos níveis de produção, necessita dos valores das vendas, dos custos dos produtos vendidos, dos estoques e dos ativos totais. A estatística descritiva destes valores é evidenciada na Tabela 27, exceto as vendas, cujos valores foram expostos na Tabela 24.

Tabela 27 - Subvariáveis do modelo GRAO NP - Inglaterra

\begin{tabular}{|c|c|c|c|c|}
\hline Estatística descritiva & 2007 & 2008 & 2009 & 2010 \\
\hline Média dos estoques & 117,058 & 129,487 & 108,201 & 113,943 \\
\hline Média dos ativos totais & 833,251 & 909,276 & 833,988 & 880,735 \\
\hline Médi & 526,349 & 91 & 484,915 & 490,890 \\
\hline Desvio-padi & 155,529 & 169,532 & 146,097 & 150,978 \\
\hline Desvio-padrão dos ativ.totais & $1,312,866$ & $1,385,800$ & $1,272,029$ & $1,333,382$ \\
\hline $\begin{array}{l}\text { S custos de } \\
\text { S }\end{array}$ & 770,638 & 720,616 & 661,579 & 692,859 \\
\hline Mínim & 0 & 0 & 22 & 0 \\
\hline Míni & 3,310 & 4,050 & 1,980 & 2,070 \\
\hline $\begin{array}{l}\text { Mínin } \\
\text { produ }\end{array}$ & 50 & 50 & 340 & 90 \\
\hline Máximo o & 649,650 & 753,340 & 685,690 & 610,780 \\
\hline Máxin & $5,454,430$ & $5,620,010$ & $4,992,280$ & $5,111,910$ \\
\hline $\begin{array}{l}\text { Máximo dos custos de } \\
\text { produtos vendidos }\end{array}$ & $3,495,130$ & $2,810,320$ & $2,273,820$ & $2,787,010$ \\
\hline
\end{tabular}

Fonte: Dados da pesquisa.

Na Tabela 27 verifica-se a estatística descritiva das subvariáveis do modelo de regressão para as 47 empresas industriais inglesas da amostra. A média anual de estoques teve redução em 2009 e recuperação parcial em 2010. A média anual dos ativos totais teve redução em 2009 e, em 2010, apresentou recuperação. A média anual dos custos dos produtos vendidos teve redução em 2008 e 2009.

O desvio padrão dos estoques, dos ativos totais e dos custos dos produtos vendidos manteve alta dispersão nos quatro anos analisados. Os estoques mínimos mantiveram-se inferiores a média, na maior parte do período com valor zero, já os máximos apresentaram-se acima da média. Por fim, os mínimos e máximos dos ativos totais e dos custos dos produtos vendidos tiveram comportamento semelhante ao dos estoques. 
Na Tabela 28 apresentam-se os coeficientes de saída do modelo de regressão aplicado aos dados das empresas industriais inglesas.

Tabela 28 - Coeficientes do modelo GRAO NP - Inglaterra

\begin{tabular}{l|c|c|c|c|c|c|c|c}
\hline \multirow{2}{*}{ Modelo } & \multicolumn{2}{|c|}{$\mathbf{2 0 0 7}$} & \multicolumn{2}{c|}{2008} & \multicolumn{2}{c|}{2009} & \multicolumn{2}{|c}{$\mathbf{2 0 1 0}$} \\
\cline { 2 - 9 } & Coef. & $\begin{array}{c}\boldsymbol{p} \text { - } \\
\text { value }\end{array}$ & Coef. & $\begin{array}{c}\boldsymbol{p} \text { - } \\
\text { value }\end{array}$ & Coef. & $\begin{array}{c}\boldsymbol{p} \text { - } \\
\text { value }\end{array}$ & Coef. & $\begin{array}{c}\boldsymbol{p} \text { - } \\
\text { value }\end{array}$ \\
\hline$\alpha_{1}$ & $-0,21$ & 0,013 & $-0,091$ & 0,139 & $-0,058$ & 0,307 & 0,019 & 0,768 \\
$\alpha_{2}$ & 0,163 & 0,778 & $-0,184$ & 0,696 & 0,059 & 0,899 & $-0,381$ & 0,263 \\
$\alpha_{3}$ & 0,800 & 0,000 & 0,778 & 0,000 & 0,673 & 0,000 & 0,609 & 0,000 \\
$\alpha_{4}$ & 0,063 & 0,539 & 0,251 & 0,001 & 0,014 & 0,880 & $-0,083$ & 0,540 \\
$\alpha_{5}$ & 0,301 & 0,000 & $-0,206$ & 0,045 & 0,234 & 0,000 & $-0,074$ & 0,411 \\
$\mathrm{R}^{2}$ Ajustado & 0,926 & - & 0,926 & - & 0,833 & - & 0,784 & - \\
Sig. & 0,000 & - & 0,000 & - & 0,000 & - & 0,000 & - \\
$\mathrm{N}^{\mathbf{o}}$ de & 47 & - & 47 & - & 47 & - & 47 & - \\
observações & 47
\end{tabular}

Fonte: Dados da pesquisa.

De acordo com Roychowdhury (2005) e Cardoso e Martinez (2006), é esperado que todos os coeficientes sejam positivos, o que indica maior probabilidade de gerenciamento pelas empresas para aumentar seus resultados do período.

Para a amostra de 47 empresas inglesas, conforme Tabela 28, nota-se que $40 \%$ dos coeficientes são positivos. No entanto, simultaneamente os cinco coeficientes não tiveram o mesmo sinal nos quatro anos analisados. Apenas em 2009 pode-se supor a prática de income increasing, ou seja, manipulação para aumentar resultados, pois o intercepto negativo possui um valor baixo e os demais são positivos. Contudo, confirmou-se a prática de gerenciamento de resultados por meio do nível de produção, devido ao valor do $\mathrm{R}^{2}$ ajustado ter apresentado alto poder explicativo do modelo nos quatro anos analisados para esta amostra. Também, pelos resultados dos testes de significância das regressões terem sido confirmados para os quatro anos analisados, inferior a 0,05 . Com relação aos coeficientes das variáveis, alguns apresentaram-se significativos em todo o período estudado, sendo que no total foram analisadas 188 observações.

Os coeficientes resultantes do cálculo do modelo de Roychowdhury (2005) possibilitaram a mensuração do gerenciamento de resultados, por meio de atividades operacionais, nível de produção e 
aumento das vendas por descontos anormais. Na Tabela 29 expõe-se a estatística descritiva dos valores encontrados para as empresas industriais inglesas no período analisado.

\begin{tabular}{l|c|c|c|c}
\multicolumn{5}{c}{ Tabela 29 - Estatística descritiva do GRAO NP - Inglaterra } \\
\hline $\begin{array}{l}\text { GRAO } \\
\text { NPP }\end{array}$ & $\mathbf{2 0 0 7}$ & $\mathbf{2 0 0 8}$ & $\mathbf{2 0 0 9}$ & $\mathbf{2 0 1 0}$ \\
\hline Média & 0,000827837 & 0,000135100 & 0,000510757 & $-0,000621356$ \\
Desvio- & 0,159897224 & 0,130998875 & 0,128256562 & 0,160250510 \\
padrão & $-0,404380952$ & $-0,345346015$ & $-0,284778340$ & $-0,567592499$ \\
Mínimo & $-0,353204492$ & 0,229306388 & 0,382153271 \\
\hline Máximo & 0,342790881 & 0,35349 \\
\hline
\end{tabular}

Fonte: Dados da pesquisa.

Observa-se na Tabela 29 que o maior valor de gerenciamento de resultados por meio do nível de produção foi de 0,382153271, em 2010, e o menor foi de $-0,567592499$, no mesmo ano. A maior média ocorreu em 2007 e a menor em 2010.

\subsubsection{Análise conjunta do BRA, EUA e ING para os Níveis de Gerenciamento de Resultados nas Atividades Operacionais}

Com relação ao gerenciamento de resultados por meio de atividades operacionais, despesas com vendas gerais e administrativas, primeiramente têm-se a comparação das Tabelas 12, 18 e 24, que apresentam as subvariáveis de input do modelo de Anderson, Banker e Janakiraman (2003). As médias de vendas das empresas industriais brasileiras obtiveram um crescimento em todo o período, enquanto que as estadunidenses e inglesas apresentaram um decréscimo, de 2007 para 2010 .

Nas mesmas tabelas, o percentual das despesas com vendas, gerais e administrativas em relação às vendas médias apresenta-se entre $4,5 \%$ e $7,2 \%$ para as empresas industriais brasileiras, respectivamente $15,1 \%$ e $16,8 \%$ para as estadunidenses e, $21,6 \%$ e $22,7 \%$ para as inglesas. Observa-se pelos percentuais que as empresas industriais brasileiras tiveram a menor despesa e as estadunidenses a maior em valores proporcionais em relação às vendas.

Comparando-se as Tabelas 13, 19 e 25, verifica-se que, embora o valor do $\mathrm{R}^{2}$ ajustado tenha apresentado baixo poder explicativo do modelo nos quatro anos pesquisados para os três países, os resultados do 
teste de significância das regressões foram confirmados estatisticamente, mantendo o coeficiente de significância inferior a 0,05, para as 30 empresas industriais brasileiras, 323 estadunidenses e 47 inglesas analisadas. A exceção foi apenas para o Brasil em 2010, que não obteve significância estatística. Entretanto, é possível inferir que houve gerenciamento de resultados por atividades operacionais, especificamente com despesas com vendas, gerais e administrativas nas empresas industriais brasileiras em 2007, 2008 e 2009 e nas estadunidenses e inglesas de 2007 a 2010.

Quanto ao nível de gerenciamento de resultados, por meio de atividades operacionais despesas com vendas, gerais e administrativas, nas empresas industriais brasileiras, estadunidenses e inglesas, no período analisado, conforme o exposto nas Tabelas 14, 20 e 26, o maior valor médio de gerenciamento ocorreu nas empresas industriais inglesas, no período de 2007 a 2010, seguindo-se as empresas estadunidenses e, por último, as brasileiras.

Com relação ao gerenciamento de resultados por meio de atividades operacionais, especificamente, despesas com pesquisa e desenvolvimento, para esta amostra não foi possível estimar esta modalidade. Ao coletar as subvariáveis do modelo de Gunny (2005), a redução da amostra inviabilizou os testes estatísticos para os três países.

Com relação ao gerenciamento de resultados por meio de atividades operacionais, níveis de produção e aumento temporário das vendas por descontos anormais, a estatística descritiva das subvariáveis do modelo de regressão de Roychowdhury (2005), apresentada nas Tabelas 15, 21 e 27, demonstra que para as 30 empresas industriais brasileiras da amostra a média anual de estoques e dos custos dos produtos vendidos se manteve crescente no período. Já nas 323 empresas industriais estadunidenses reduziu em 2009, obtendo recuperação total em 2010. Para as 47 empresas industriais inglesas houve redução em 2009 e recuperação parcial em 2010.

Comparando-se as Tabelas 16, 22 e 28, verifica-se que os coeficientes esperados de saída do referido modelo de regressão era de sinal positivo, pois maiores vendas estão atreladas a maiores níveis de produção. Este fato leva a inferir que houve maior probabilidade de gerenciamento pelas empresas para aumentar seus resultados do período. Entretanto, os resultados encontrados nesta pesquisa não permitem tal constatação teórica, pois nenhum dos três países obteve todos os coeficientes positivos no mesmo ano, nem mesmo negativos. Há apenas uma suposição de que tenha havido prática de income increasing pelas empresas industriais inglesas em 2009. 
No entanto, confirmou-se a prática de gerenciamento de resultados por manipulação do nível de produção para as empresas industriais dos três países analisados, devido ao valor do $\mathrm{R}^{2}$ ajustado ter apresentado alto poder explicativo do modelo em todo o período, também, pelos resultados dos testes de significância das regressões terem sido confirmados, inferior a 0,05 de 2007 a 2010.

Quanto ao nível de gerenciamento de resultados, por meio de atividades operacionais, nível de produção e aumento temporário das vendas por meio de descontos anormais nas empresas industriais brasileiras, estadunidenses e inglesas no período analisado, conforme o exposto nas Tabelas 17, 23 e 29, o maior valor médio de gerenciamento ocorreu nas empresas industriais inglesas no período de 2007 a 2010, em segundo lugar nas empresas estadunidenses e, por último, nas brasileiras.

Anderson, Banker e Janakiramam (2003), ao pesquisar o gerenciamento por meio de atividades operacionais, despesas com vendas, gerais e administrativas e níveis de produção, ressaltam que:

a) há uma suposição fundamental de que o aumento do volume e dos custos de produção possui uma relação de contabilização simétrica, ou seja, ambos aumentam e diminuem seus valores simetricamente, aumentando seus custos quando há mais atividade e reduzindo quando contrário. Entretanto, os resultados da pesquisa dos autores indicaram que os gestores deliberadamente ajustam os recursos comprometidos com as atividades;

b) os resultados da pesquisa dos autores para as atividades operacionais, despesas com vendas, gerais e administrativas indicou que as despesas aumentam, em média, $0,55 \%$ pelo aumento de $1 \%$ nas vendas, mas diminuem $0,35 \%$ pela diminuição de $1 \%$ nas vendas. Os autores concluíram que as despesas variam de acordo com as circunstâncias e não pela atividade.

Nesta pesquisa pode-se confirmar a evidência de Anderson, Banker e Janakiramam (2003), de que os gestores ajustam deliberadamente os recursos, conforme determinadas circunstâncias e não de acordo com o volume de atividade.

O primeiro estudo realizado, buscando identificar evidências do gerenciamento da informação contábil mediante decisões operacionais, em empresas brasileiras foi o de Cardoso e Martinez (2006). A amostra da pesquisa compreendeu 315 empresas, não financeiras e não 
seguradoras, com ações negociadas na BM\&FBovespa e os resultados indicam que as empresas gerenciam, sim, os números contábeis mediante decisões operacionais e escolhas contábeis.

A inferência de Cardoso e Martinez (2006), de que empresas brasileiras gerenciam os números contábeis mediante decisões operacionais, se confirmou nesta pesquisa, pois as variáveis estudadas explicam o gerenciamento de resultados, por meio de atividades operacionais, despesas com vendas, gerais e administrativas e níveis de produção para as empresas industriais brasileiras, estadunidenses e inglesas analisadas.

Gunny (2005) examinou as consequências de quatro tipos de gerenciamento por atividades operacionais: a) capitalizar despesas de pesquisa e desenvolvimento para aumentar o resultado; b) investir de forma míope em despesas com vendas, gerais e administrativas para aumentar as receitas; c) reconhecer intempestivamente ganhos provenientes de alienação de ativos de longa duração; e d) reduzir preços para impulsionar as vendas no período corrente e reduzir custos de produção. Os resultados empíricos foram compatíveis com os quatro tipos de atividades de gerenciamento de resultados, tendo um impacto significativamente negativo sobre o desempenho futuro das ações das empresas. Nesta pesquisa foram constatados os itens ' $a$ ' $e$ ' $b$ ' corroborando os resultados da autora.

Roychowdhury (2005) constatou em sua pesquisa que os gestores praticam gerenciamento de resultados por meio de manipulação de atividades operacionais para evitar reportar perdas anuais nas demonstrações financeiras das empresas. Essa evidência de prática de smoothing também é corroborada pelos resultados desta pesquisa, principalmente ao realizar descontos para aumentar temporariamente as vendas, ao viabilizar excesso de produção para relatar menor custo das mercadorias vendidas e ao reduzir despesas discricionárias para melhorar as margens divulgadas.

Zang (2005) investigou se os gestores utilizam manipulações por atividades operacionais e por accruals como substitutos na gestão de resultados e em que ordem os gestores tomam estas decisões. Os resultados da pesquisa demonstraram que uma forma de gerenciamento se sobrepõe a outra, ou seja, quanto maior o gerenciamento por atividades operacionais, menor o gerenciamento por accruals e viceversa. Nesta pesquisa esse fato não foi objeto de estudo, portanto, impedindo que fosse possível efetuar uma comparação ou confirmação.

Ao final da execução do objetivo específico ' $b$ ' desta pesquisa foi possível identificar que houve gerenciamento de resultados por 
manipulação de atividades operacionais, especificamente, despesas com vendas, gerais e administrativas e por manejo nos níveis de produção, para as empresas industriais brasileiras, estadunidenses e inglesas da amostra analisada.

\subsection{NÍVEL DE GERENCIAMENTO DE RESULTADOS NAS ACCRUALS DISCRICIONÁRIAS}

Nesta seção apresenta-se a análise do gerenciamento de resultados a partir das accruals discricionárias das empresas industriais brasileiras, estadunidenses e inglesas. Todos os valores relativos aos inputs dos modelos, ou seja, relativos aos dados contábeis encontram-se em milhares de dólares norte-americanos.

\subsubsection{Empresas Industriais Brasileiras}

Para estimar o modelo de Dechow, Sloan e Sweeney (1995) de gerenciamento de resultados por meio de accruals agregadas são necessários os valores de depreciação e amortização, contas a receber, imobilizado operacional, capital circulante líquido, ativo total e vendas. A estatística descritiva destes valores é evidenciada na Tabela 30, exceto as vendas e os ativos totais, cujos valores foram expostos nas Tabelas 12 e 15 , respectivamente.

Tabela 30 - Estatística descritiva subv. das accruals agregadas BRA

\begin{tabular}{l|r|r|r|r}
\hline \multicolumn{1}{c|}{ Estatística descritiva } & \multicolumn{1}{c|}{$\mathbf{2 0 0 7}$} & \multicolumn{1}{c|}{$\mathbf{2 0 0 8}$} & \multicolumn{1}{c|}{$\mathbf{2 0 0 9}$} & \multicolumn{1}{c}{$\mathbf{2 0 1 0}$} \\
\hline Média da depreciação e & 12,838 & 20,140 & 27,413 & 38,980 \\
amortização & 74,948 & 75,681 & 109,430 & 137,860 \\
$\begin{array}{l}\text { Média das contas a receber } \\
\text { Média do imobilizado }\end{array}$ & 143,713 & 145,367 & 322,728 & 440,567 \\
$\begin{array}{l}\text { operacional } \\
\text { Média do capital circulante }\end{array}$ & 108,298 & 110,909 & 218,378 & 203,205 \\
\hline líquido & 32,430 & 48,581 & 67,565 & 108,017 \\
\hline $\begin{array}{l}\text { Desvio-padrão da } \\
\text { depreciação e amortização }\end{array}$ & 115,545 & 132,851 & 211,134 & 297,877 \\
$\begin{array}{l}\text { Desvio-padrão das contas a } \\
\text { receber }\end{array}$ & 250,053 & 285,033 & 995,594 & $1,168,474$ \\
$\begin{array}{l}\text { Desvio-padrão do } \\
\text { imobilizado operacional }\end{array}$ & 247,476 & 280,574 & 609,136 & 516,044 \\
\hline \begin{tabular}{l} 
Desvio-padrão do capital \\
\hline
\end{tabular}
\end{tabular}




\begin{tabular}{l|r|r|r|r} 
circulante líquido & & & & \\
\hline $\begin{array}{l}\text { Mínimo da depreciação e } \\
\text { amortização }\end{array}$ & 0 & 5 & -784 & 0 \\
$\begin{array}{l}\text { Mínimo das contas a } \\
\text { receber }\end{array}$ & 67 & 1 & 2 & 108 \\
$\begin{array}{l}\text { Mínimo do imobilizado } \\
\text { operacional }\end{array}$ & 169 & 6 & 7 & 5 \\
$\begin{array}{l}\text { Mínimo do capital } \\
\text { circulante líquido }\end{array}$ & $-245,046$ & $-227,330$ & $-294,323$ & $-105,931$ \\
\hline $\begin{array}{l}\text { Máximo da depreciação e } \\
\text { amortização }\end{array}$ & 165,898 & 261,548 & 343,458 & 488,619 \\
$\begin{array}{l}\text { Máximo das contas a } \\
\text { receber }\end{array}$ & 454,202 & 599,150 & $1,039,149$ & $1,491,296$ \\
$\begin{array}{l}\text { Máximo do imobilizado } \\
\text { operacional }\end{array}$ & $1,207,298$ & $1,268,895$ & $5,392,436$ & $5,271,413$ \\
$\begin{array}{l}\text { Máximo do capital } \\
\text { circulante líquido }\end{array}$ & $1,032,164$ & $1,262,732$ & $2,656,771$ & $2,421,945$ \\
\hline
\end{tabular}

Fonte: Dados da pesquisa.

Verifica-se na Tabela 30 que os valores médios da depreciação e amortização tiverem incremento ao longo do período. A média anual das contas a receber se manteve crescente no período analisado, entretanto teve um incremento significativo em 2009, em relação ao ano anterior.

Comparando-se a média anual do ativo imobilizado operacional entre os quatro anos, nota-se que houve novos investimentos, principalmente em 2009. A média anual do capital circulante líquido teve redução apenas em 2010.

O desvio-padrão da depreciação e amortização teve menor variabilidade em relação à média em 2007 e 2008, mas em 2009 e 2010 apresentou uma dispersão maior.

O desvio-padrão das contas a receber, do imobilizado operacional e do capital circulante líquido apresentaram alta dispersão em todo o período. Por fim, os mínimos e máximos representam as diferenças de tamanho entre as empresas.

Na Tabela 31 verificam-se os coeficientes encontrados no modelo de regressão de Dechow, Sloan e Sweeney (1995) de accruals agregadas. 
Tabela 31 - Coeficientes do modelo de accruals agregadas - BRA

\begin{tabular}{|c|c|c|c|c|c|c|c|c|}
\hline \multirow[b]{2}{*}{ Modelo } & \multicolumn{2}{|c|}{2007} & \multicolumn{2}{|c|}{2008} & \multicolumn{2}{|c|}{2009} & \multicolumn{2}{|c|}{2010} \\
\hline & Coef. & $\begin{array}{c}p- \\
\text { value }\end{array}$ & Coef. & $\begin{array}{c}p- \\
\text { value }\end{array}$ & Coef. & $\begin{array}{c}p- \\
\text { value }\end{array}$ & Coef. & $\begin{array}{c}p- \\
\text { value }\end{array}$ \\
\hline$\alpha_{0}$ & $-17,013$ & 0,000 & 10,402 & 0,000 & $-28,349$ & 0,000 & $-15,458$ & 0,000 \\
\hline$\alpha_{1}$ & 0,919 & 0,000 & 0,253 & 0,185 & 1,130 & 0,078 & 0,385 & 0,062 \\
\hline$\alpha_{2}$ & 0,049 & 0,811 & $-0,513$ & 0,000 & 0,552 & 0,214 & $-0,270$ & 0,678 \\
\hline $\begin{array}{l}\mathrm{R}^{2} \\
\text { Ajusta- } \\
\text { do }\end{array}$ & 0,981 & - & 0,982 & - & 0,975 & - & 0,987 & - \\
\hline Sig. & 0,000 & - & 0,000 & - & 0,000 & - & 0,000 & - \\
\hline $\begin{array}{l}N^{o} \text { de } \\
\text { obs. }\end{array}$ & 30 & - & 30 & - & 30 & - & 30 & - \\
\hline
\end{tabular}

Fonte: Dados da pesquisa.

Conforme se observa na Tabela 31, os resultados obtidos para os coeficientes de regressão do modelo de Dechow, Sloan e Sweeney (1995), parte não discricionária das accruals, o modelo apresentou forte poder de explicação em todo o período e foi estatisticamente significativo, fato que confirma o gerenciamento de resultados por accruals totais nas empresas industriais brasileiras da amostra.

A partir dos coeficientes obtidos das accruals não discricionárias, do modelo de Dechow, Sloan e Sweeney (1995), foi possível realizar a mensuração da parte discricionária. Na Tabela 32 mostram-se os valores de accruals discricionárias encontradas no referido modelo.

Tabela 32 - Accruals discricionárias - BRA

\begin{tabular}{l|c|r|r|r}
\hline $\begin{array}{c}\text { Accruals } \\
\text { Discricionárias }\end{array}$ & $\mathbf{2 0 0 7}$ & $\mathbf{2 0 0 8}$ & $\mathbf{2 0 0 9}$ & $\mathbf{2 0 1 0}$ \\
\hline Média & 0,00951713 & $-0,02755146$ & 0,02532317 & 0,06018765 \\
Desvio-padrão & 0,37122409 & 0,16328185 & 0,87180756 & 0,24715314 \\
Mínimo & $-0,62621740$ & $-0,41892165$ & $-1,28181489$ & $-0,35561939$ \\
Máximo & 1,34768942 & 0,27270574 & 2,88383713 & 0,95917470 \\
\hline
\end{tabular}

Fonte: Dados da pesquisa.

Verifica-se na Tabela 32 que o maior valor de gerenciamento de resultados por meio das accruals discricionárias foi de 2,88383713, em 
2009, e o menor foi de $-1,28181489$, no mesmo ano. A maior média foi de 0,060187655, em 2010, e a menor foi de -0,02755146, em 2008.

Nesta pesquisa, confirmou-se a efetivação da prática de gerenciamento de resultados por manipulação de accruals discricionárias nas empresas industriais brasileiras estudadas, ratificando os resultados das pesquisas com empresas brasileiras realizadas por Martinez (2001), Matos e Sancovschi (2005), Paulo (2007) e Baptista (2008).

\subsubsection{Empresas Industriais Estadunidenses}

Para estimação do modelo de Dechow, Sloan e Sweeney (1995) de gerenciamento de resultados por meio de accruals agregadas são necessários os valores de depreciação e amortização, contas a receber, imobilizado operacional, capital circulante líquido, vendas e ativo total. A estatística descritiva destes valores, para as empresas estadunidenses, é evidenciada na Tabela 33, com exceção das vendas e do ativo total, expostos nas Tabelas 18 e 21, respectivamente.

Tabela 33 - Estatística descritiva subv. das accruals agregadas EUA

\begin{tabular}{l|r|r|r|r}
\hline \multicolumn{1}{c|}{ Estatística descritiva } & \multicolumn{1}{c|}{$\mathbf{2 0 0 7}$} & \multicolumn{1}{c|}{$\mathbf{2 0 0 8}$} & \multicolumn{1}{c|}{$\mathbf{2 0 0 9}$} & \multicolumn{1}{c}{$\mathbf{2 0 1 0}$} \\
\hline $\begin{array}{l}\text { Média da depreciação e } \\
\text { amortização }\end{array}$ & 63,403 & 68,994 & 70,150 & 70,477 \\
$\begin{array}{l}\text { Média das contas a receber } \\
\text { Média do imobilizado } \\
\text { operacional }\end{array}$ & 425,206 & 424,528 & 378,254 & 427,121 \\
$\begin{array}{l}\text { Média do capital circulante } \\
\text { líquido }\end{array}$ & 841,746 & 872,778 & 901,731 & 918,470 \\
$\begin{array}{l}\text { Desvio-padrão da } \\
\text { depreciação e amortização }\end{array}$ & 167,696 & 183,700 & 195,365 & 196,284 \\
$\begin{array}{l}\text { Desvio-padrão das contas a } \\
\text { receber }\end{array}$ & $1,727,638$ & $1,783,168$ & $1,631,815$ & $1,880,539$ \\
$\begin{array}{l}\text { Desvio-padrão do } \\
\text { imobilizado operacional }\end{array}$ & $2,195,051$ & $2,333,785$ & $2,415,089$ & $2,457,564$ \\
$\begin{array}{l}\text { Desvio-padrão do capital } \\
\text { circulante líquido }\end{array}$ & 913,439 & 938,694 & $1,209,046$ & $1,357,465$ \\
\hline $\begin{array}{l}\text { Mínimo da depreciação e } \\
\text { amortização }\end{array}$ & 10 & 0 & 0 & 0 \\
$\begin{array}{l}\text { Mínimo das contas a } \\
\text { receber }\end{array}$ & 10 & 0 & 0 & 0 \\
\hline
\end{tabular}




\begin{tabular}{l|r|r|r|r}
$\begin{array}{l}\text { Mínimo do imobilizado } \\
\text { operacional }\end{array}$ & 20 & 20 & 10 & 10 \\
$\begin{array}{l}\text { Mínimo do capital } \\
\text { circulante líquido }\end{array}$ & 220 & 160 & 530 & 150 \\
\hline $\begin{array}{l}\text { Máximo da depreciação e } \\
\text { amortização }\end{array}$ & $1,797,000$ & $1,980,000$ & $2,336,000$ & $2,296,000$ \\
$\begin{array}{l}\text { Máximo das contas a } \\
\text { receber }\end{array}$ & $21,601,100$ & $21,606,000$ & $21,882,900$ & $25,575,000$ \\
$\begin{array}{l}\text { Máximo do imobilizado } \\
\text { operacional }\end{array}$ & $19,208,000$ & $23,487,000$ & $24,221,000$ & $24,906,000$ \\
$\begin{array}{l}\text { Máximo do capital } \\
\text { circulante líquido }\end{array}$ & $12,102,200$ & $12,753,300$ & $16,538,600$ & $18,436,800$ \\
\hline
\end{tabular}

Fonte: Dados da pesquisa.

Na Tabela 33 se observa que as médias anuais das três rubricas (depreciação e amortização, imobilizado operacional e capital circulante líquido) se mantiveram crescentes em todo o período analisado. A excessão ficou na conta patrimonial, denominada contas a receber, que teve redução em 2008 e 2009, voltando a se recuperar em 2010. Verifica-se também que os desvios padrões das três rubricas tiveram alta variabilidade em relação à média nos quatro anos. Os mínimos e os máximos representam as diferenças entre o tamanho das empresas da amostra.

Na Tabela 34 apresentam-se os coeficientes encontrados no modelo de regressão de Dechow, Sloan e Sweeney (1995) de accruals agregadas.

Tabela 34 - Coeficientes do modelo de accruals agregadas - EUA

\begin{tabular}{l|c|c|c|c|c|c|c|c}
\hline \multirow{2}{*}{ Modelo } & \multicolumn{2}{|c|}{$\mathbf{2 0 0 7}$} & \multicolumn{2}{c|}{$\mathbf{2 0 0 8}$} & \multicolumn{2}{c|}{2009} & \multicolumn{2}{c}{$\mathbf{2 0 1 0}$} \\
\cline { 2 - 9 } & Coef. & $\begin{array}{c}\boldsymbol{p} \text { - } \\
\text { value }\end{array}$ & Coef. & $\begin{array}{c}\boldsymbol{p} \text { - } \\
\text { value }\end{array}$ & Coef. & $\begin{array}{c}\boldsymbol{p} \text { - } \\
\text { value }\end{array}$ & Coef. & $\begin{array}{c}\boldsymbol{p} \text { - } \\
\text { value }\end{array}$ \\
\hline$\alpha_{0}$ & 0,042 & 0,196 & $-0,045$ & 0,000 & 0,676 & 0,000 & $-0,236$ & 0,005 \\
$\alpha_{1}$ & 0,151 & 0,000 & 0,106 & 0,185 & 0,111 & 0,000 & 0,151 & 0,000 \\
$\alpha_{2}$ & $-0,040$ & 0,001 & $-0,053$ & 0,000 & $-0,042$ & 0,000 & $-0,019$ & 0,153 \\
$\mathrm{R}^{2}$ Ajustado & 0,094 & - & 0,086 & - & 0,732 & - & 0,144 & - \\
Sig. & 0,000 & - & 0,000 & - & 0,000 & - & 0,000 & - \\
$\mathrm{N}^{\circ}$ de & 323 & - & 323 & - & 323 & - & 323 & - \\
observações & 323 & - &
\end{tabular}

Fonte: Dados da pesquisa. 
Observa-se na Tabela 34, dos resultados obtidos para os coeficientes de regressão, que o modelo apresentou baixo poder de explicação em todo o período. Entretanto, foi estatisticamente significativo, fato que confirma o gerenciamento de resultados por accruals agregadas.

Com base nos coeficientes obtidos do modelo de Dechow, Sloan e Sweeney (1995), para a parte não discricionária das accruals agregadas, foi possível mensurar a parte discricionária. Na Tabela 35 verificam-se os valores de accruals discricionárias encontradas no modelo de regressão.

Tabela 35 - Accruals discricionárias - EUA

\begin{tabular}{l|c|r|r|r}
\hline $\begin{array}{c}\text { Accruals } \\
\text { Discricionárias }\end{array}$ & $\mathbf{2 0 0 7}$ & $\mathbf{2 0 0 8}$ & $\mathbf{2 0 0 9}$ & \multicolumn{1}{c}{$\mathbf{2 0 1 0}$} \\
\hline Média & 0,19334361 & $-0,01260022$ & $-0,00285929$ & $-0,00525471$ \\
Desvio-padrão & 0,16990103 & 0,11526954 & 0,11023017 & 0,15205802 \\
Mínimo & $-0,31375683$ & $-0,63823316$ & $-0,64332098$ & $-0,51644047$ \\
Máximo & 0,99506718 & 0,58090644 & 0,77525280 & 1,94102334 \\
\hline
\end{tabular}

Fonte: Dados da pesquisa.

$\mathrm{Na}$ Tabela 35 nota-se que o maior valor de accruals discricionárias foi de 1,94102334, em 2010, e o menor foi de 0,64332098, em 2009. A maior média foi de 0,19334361, em 2007, e a menor foi de $-0,01260022$, em 2008.

A efetivação da prática de gerenciamento de resultados por manipulação de accruals discricionárias foi comprovada nesta pesquisa para as empresas industriais estadunidenses, corroborando pesquisas anteriores realizadas com empresas dos Estados Unidos, como a de DeFond e Jiambalvo (1994), DeAngelo, DeAngelo e Skinner (1994), Dechow, Sloan e Sweeney (1995) e Healy e Wahlen (1999).

\subsubsection{Empresas Industriais Inglesas}

A estimação do modelo de Dechow, Sloan e Sweeney (1995) de gerenciamento de resultados por meio de accruals agregadas necessita dos valores de depreciação e amortização, contas a receber, imobilizado operacional, capital circulante líquido, vendas e ativo total. A estatística descritiva destes valores, para as empresas inglesas, está demonstrada na Tabela 36, com exceção das vendas e dos ativos totais expostos nas Tabelas 24 e 27, respectivamente. 
Tabela 36 - Estatística descritiva subv. das accruals agregadas ING

\begin{tabular}{|c|c|c|c|c|}
\hline Estatística descritiva & 2007 & 2008 & 2009 & 2010 \\
\hline $\begin{array}{l}\text { Média da depreciação e } \\
\text { amortização }\end{array}$ & 27,492 & 28,157 & 31,865 & 32,479 \\
\hline Média das contas a receber & 177,626 & 179,205 & 148,020 & 159,427 \\
\hline $\begin{array}{l}\text { Média do imobilizado } \\
\text { operacional }\end{array}$ & 322,902 & 334,589 & 321,804 & 326,217 \\
\hline $\begin{array}{l}\text { Média do capital circulante } \\
\text { líquido }\end{array}$ & 131,810 & 134,540 & 109,124 & 134,840 \\
\hline $\begin{array}{l}\text { Desvio-padrão da depreciação } \\
\text { e amortização }\end{array}$ & 39,340 & 40,877 & 46,638 & 47,542 \\
\hline $\begin{array}{l}\text { Desvio-padrão das contas a } \\
\text { receber }\end{array}$ & 281,781 & 282,236 & 226,947 & 241,722 \\
\hline $\begin{array}{l}\text { Desvio-padrão do imobilizado } \\
\text { operacional }\end{array}$ & 535,418 & 561,284 & 500,226 & 500,684 \\
\hline $\begin{array}{l}\text { Desvio-padrão do capital } \\
\text { circulante líquido }\end{array}$ & 179,095 & 169,535 & 135,815 & 179,608 \\
\hline $\begin{array}{l}\text { Mínimo da depreciação e } \\
\text { amortização }\end{array}$ & 150 & 100 & 80 & 60 \\
\hline Mínimo das contas a receber & 330 & 340 & 250 & 340 \\
\hline $\begin{array}{l}\text { Mínimo do imobilizado } \\
\text { operacional }\end{array}$ & 570 & 870 & 920 & 830 \\
\hline $\begin{array}{l}\text { Mínimo do capital circulante } \\
\text { líquido }\end{array}$ & 2,220 & 920 & 1,070 & 640 \\
\hline $\begin{array}{l}\text { Máximo da depreciação e } \\
\text { amortização }\end{array}$ & 142,930 & 166,790 & 204,120 & 208,760 \\
\hline Máximo das contas a receber & $1,420,020$ & $1,319,700$ & $1,047,780$ & $1,017,840$ \\
\hline $\begin{array}{l}\text { Máximo do imobilizado } \\
\text { operacional }\end{array}$ & $2,637,600$ & $2,940,920$ & $2,327,460$ & $2,323,680$ \\
\hline $\begin{array}{l}\text { Máximo do capital circulante } \\
\text { líquido }\end{array}$ & 769,960 & 703,580 & 534,640 & 808,730 \\
\hline
\end{tabular}

Fonte: Dados da pesquisa.

Na Tabela 36 visualiza-se que a média anual da depreciação e amortização se manteve crescente em pequena proporção a cada ano. A média das contas a receber teve uma queda acentuada em 2009, e em 2010 teve uma recuperação parcial em relação a 2007. O desvio-padrão apresentou alta dispersão para as quatro rubricas em todo o período analisado. Os mínimos e os máximos evidenciam as diferenças de tamanho das empresas estadunidenses da amostra. 
Na Tabela 37 relacionam-se os coeficientes do modelo de regressão aplicado aos dados das empresas inglesas, ou seja, o modelo de accruals agregadas.

Tabela 37 - Coeficientes do modelo de accruals agregadas - ING

\begin{tabular}{l|c|c|c|c|c|c|c|c}
\hline \multirow{2}{*}{ Modelo } & \multicolumn{2}{|c|}{2007} & \multicolumn{2}{c|}{2008} & \multicolumn{2}{c|}{2009} & \multicolumn{2}{c}{2010} \\
\cline { 2 - 9 } & Coef. & $\begin{array}{c}\boldsymbol{p} \text { - } \\
\text { value }\end{array}$ & Coef. & $\begin{array}{c}\boldsymbol{p} \text { - } \\
\text { value }\end{array}$ & Coef. & $\begin{array}{c}\boldsymbol{p} \text { - } \\
\text { value }\end{array}$ & Coef. & $\begin{array}{c}\boldsymbol{p} \text { - } \\
\text { value }\end{array}$ \\
\hline$\alpha_{1}$ & 0,613 & 0,277 & $-0,230$ & 0,613 & 0,757 & 0,189 & 0,645 & 0,354 \\
$\alpha_{2}$ & $-0,019$ & 0,796 & 0,097 & 0,161 & 0,405 & 0,013 & $-0,189$ & 0,460 \\
$\alpha_{3}$ & $-0,037$ & 0,466 & $-0,060$ & 0,159 & $-0,136$ & 0,021 & $-0,043$ & 0,631 \\
$\mathrm{R}^{2}$ Ajustado & $-0,032$ & - & 0,026 & - & 0,209 & - & $-0,037$ & - \\
$\begin{array}{l}\text { Sig. } \\
\mathrm{N}^{\mathbf{0}} \text { de } \\
\text { observações }\end{array}$ & 0,675 & - & 0,251 & - & 0,004 & - & 0,720 & - \\
\hline
\end{tabular}

Fonte: Dados da pesquisa.

De acordo com os valores apresentados na Tabela 37, dos resultados obtidos para os coeficientes de regressão, nota-se que o modelo apresentou baixo poder de explicação em todo o período analisado. Também, que o gerenciamento de resultados por accruals discricionárias só se confirmou para o ano de 2009, o qual teve o teste de significância da regressão estatisticamente significativo, ou seja, inferior a 0,05 .

$\mathrm{Na}$ Tabela 38 evidenciam-se os valores de accruals discricionárias encontradas no modelo de regressão aplicado aos dados das empresas inglesas.

Tabela 38 - Accruals discricionárias - ING

\begin{tabular}{l|r|r|r|c}
\hline $\begin{array}{c}\text { Accruals } \\
\text { Discricionárias }\end{array}$ & $\mathbf{2 0 0 7}$ & $\mathbf{2 0 0 8}$ & $\mathbf{2 0 0 9}$ & $\mathbf{2 0 1 0}$ \\
\hline Média & 0,02447205 & $-0,01043685$ & $-0,01129656$ & 0,02877521 \\
Desvio-padrão & 0,17717977 & 0,14145690 & 0,17672342 & 0,34437753 \\
Mínimo & $-0,48025879$ & $-0,56113910$ & $-0,63199506$ & $-0,35557037$ \\
Máximo & 0,70734114 & 0,42734459 & 0,85493738 & 2,21083948 \\
\hline
\end{tabular}

Fonte: Dados da pesquisa. 
Na Tabela 38 verifica-se que o maior valor de accruals discricionárias foi de 2,21083948, em 2010, e o menor foi de 0,63199506, em 2009. A maior média foi de 0,02877521, em 2010, e a menor foi de $-0,01129656$, em 2009.

Sobre a prática de gerenciamento de resultados por manipulação de accruals discricionárias nas empresas industriais inglesas estudadas, apenas em 2009 foi obtida a validação. Entretanto, com este resultado é possível confirmar, assim como na pesquisa de Iqbal e Strong (2010), que as empresas inglesas gerenciam resultados por manipulação de accruals discricionárias.

\subsubsection{Análise conjunta do BRA, EUA e ING dos Níveis de Gerenciamento de Resultados nas Accruals Discricionárias}

Com relação aos valores das estatísticas descritivas apresentadas para as empresas industriais brasileiras, estadunidenses e inglesas da amostra estudada, representativas das subvariáveis de entrada no modelo de regressão utilizado para mensuração do gerenciamento de resultados por accruals agregadas, com o intuito de obter as accruals discricionárias, conforme demonstrado nas Tabelas 30, 33 e 36, o comportamento das médias anuais das quatro rubricas, de forma geral, foi semelhante, entre os países, mantendo-se crescentes a cada ano. As exceções ficaram por conta da redução do capital circulante líquido, em 2010 para as empresas industriais brasileiras e em 2009 para as inglesas, e da redução das contas a receber, em 2008 e 2010 para as empresas industriais estadunidenses.

Comparando-se as Tabelas 31, 34 e 37, nota-se que o gerenciamento de resultados por accruals discricionárias foi confirmado para as empresas industriais brasileiras e estadunidenses em todo o período analisado, já para as inglesas apenas em 2009. O modelo teve alto poder explicativo para as empresas industriais brasileiras e o inverso para as estadunidenses e inglesas.

De acordo com as Tabelas 32, 35 e 38, relativas aos valores de accruals discricionárias encontrados pelo cálculo do modelo de regressão, o maior valor de gerenciamento de resultados foi das empresas brasileiras, seguindo-se das inglesas e, por último, as estadunidenses.

Nesta pesquisa foram investigadas as contas patrimoniais, como objeto do gerenciamento de resultados por accruals discricionárias. Segundo Schipper (1989), esta é uma possibilidade para esta prática, embora algumas não sejam fáceis de distinguir empiricamente, como a 
decisão entre investimento ou produção. A regulamentação contábil, segundo a autora, possui um papel importante nesta prática. Conforme Yaping (2005), esta vai determinar o limite entre gerenciamento de resultados, contabilidade criativa ou fraude nos resultados contábeis.

Conforme Dechow, Sloan e Sweeney (1995), a escolha pela utilização do modelo de detecção das accruals discricionárias independe das vantagens e desvantagens de cada modelo, pois quando há significância estatística efetivamente ocorre a sua prática. Nesta pesquisa seguiu-se a recomendação dos autores de considerar o desempenho da empresa no contexto de estudo, isso está apresentado ao final deste capítulo conjuntamente com a exposição dos resultados, discutido no último objetivo específico.

Burgstahler e Dichev (1997) encontraram evidências de que o fluxo de caixa das operações e as mudanças no capital de giro são usadas para obter aumentos nas receitas, com o objetivo de gerenciamento de resultados. As alterações no capital de giro foram avaliadas como parte do modelo de detecção de accruals discricionárias utilizado nesta pesquisa, corroborando o resultado dos autores para esta variável.

Healy e Wahlen (1999) buscaram demonstrar empiricamente que as empresas gerenciam os seus resultados contábeis como resposta a estímulos do mercado de capitais. Martinez (2001) confirmou essa afirmação em pesquisa com as companhias abertas brasileiras. Os resultados demonstraram que as empresas com resultados muito ruins os manejam de maneira a piorá-los ainda mais, visando melhores resultados no futuro. Nesta pesquisa, a prática de gerenciamento de resultados foi confirmada pelas empresas industriais brasileiras, que também compuseram parcialmente a amostra de estudo do autor.

Baptista (2008) buscou delinear o perfil das empresas brasileiras com maior propensão ao gerenciamento de resultados, investigando o padrão de accruals discricionárias que representam os incentivos à prática de gerenciamento. Os resultados da pesquisa indicaram que maiores níveis de accruals, tanto positivos como negativos, podem ser associados a empresas com maior expectativa de crescimento, maior exposição ao risco e menor concentração acionária. Também, que são mais propensas ao gerenciamento as empresas não listadas nos segmentos especiais da BM\&FBovespa, que não apresentam programa de American Depositary Receipts (ADRs), que tem plano de opções, que apresentam contratação de serviços não relacionados à auditoria junto ao auditor independente, com valor de 5\% dos serviços de auditoria, e que tem parecer de auditoria com ressalva. 
Tais características não foram investigadas nesta pesquisa. Entretanto, as empresas industriais brasileiras da amostra também possuem ações negociadas na BMF\&Bovespa, fato que não descarta a possível presença dessas características como explicação da ocorrência da prática de gerenciamento de resultados por accruals discricionárias.

Basiruddin (2011) analisou características de governança corporativa, da qualidade da auditoria e do gerenciamento de resultados, por meio de pesquisa empírica, e concluiu que quanto melhor a qualidade da governança e da auditoria menor a manipulação de resultados. Tais características não fizeram parte desta pesquisa, mas esse achado indica uma contribuição para a redução do gerenciamento de resultados nas empresas.

O Índice de Gini tem sido utilizado em pesquisas que discutem a distribuição da riqueza, mais especificamente a heterogeneidade desta distribuição. Nesta pesquisa, utilizou-se o Índice de Gini adaptado, como uma forma alternativa de demonstrar a distribuição das accruals discricionárias para os três países.

De posse dos valores calculados para as accruals discricionárias, por país e por ano, verificaram-se os valores encontrados no Índice de Gini adaptado. Este índice encontra-se exposto na Tabela 39 para as empresas industriais da amostra estudada.

\section{Tabela 39 - Índice de Gini adaptado - BRA, EUA e ING}

\begin{tabular}{l|c|c|c|c}
\hline \multicolumn{1}{c|}{$\begin{array}{c}\text { Empresas } \\
\text { industriais }\end{array}$} & $\mathbf{2 0 0 7}$ & $\mathbf{2 0 0 8}$ & $\mathbf{2 0 0 9}$ & $\mathbf{2 0 1 0}$ \\
\hline BRA & 0,458480020 & 0,448896372 & 0,492469445 & 0,449724087 \\
EUA & 0,382556227 & 0,519849707 & 0,505796883 & 0,554261149 \\
ING & 0,558835487 & 0,580923696 & 0,554576258 & 0,665314940 \\
\hline
\end{tabular}

Fonte: Dados da pesquisa.

Na Tabela 39 verifica-se o resultado do índice de Gini adaptado, calculado a partir das accruals discricionárias. Destaca-se que a adaptação se refere à modulação dos valores de entrada do cálculo. Dessa forma, o sinal positivo ou negativo foi desconsiderado, apenas foi avaliado que houve um maior ou menor valor de gerenciamento, independente de ser negativo ou positivo. Os resultados de forma geral apresentaram valores próximos, tanto por ano, como por país. Nota-se que em cada país os valores se mantém estáveis, ou com variações, a partir da segunda ou terceira casa decimal apenas, a excessão das 
empresas industriais estadunidenses que tiveram um aumento diferenciado de 2007 para 2009 e das inglesas de 2009 para 2010.

Para as empresas industriais brasileiras houve uma redução de aproximadamente 1,9\% no índice de Gini adaptado de 2007 para 2010, para as estadunidenses o índice aumentou aproximadamente $45 \%$ no mesmo período, para as inglesas o índice teve um aumento de aproximadamente $19 \%$ de 2007 para 2010.

O Índice de Gini, segundo Moura Neto (2008), representa uma medida de desigualdade na distribuição da riqueza, varia de zero a um, e quanto mais perto de um, mais desigual é a distribuição. Assim, na adaptação feita para este estudo, subentende-se que a distribuição das accruals discricionárias nas empresas industriais não é homogênea, mas os valores são aproximados e estão em maior parte direcionados a desigualdade de distribuição. Não houve situação de perfeita igualdade em que o Gini apresenta valor igual a 'zero' e tampouco de máxima desigualdade de valor igual a 'um'. Ainda assim, o maior índice foi para as empresas industriais inglesas nos quatro anos consecutivos, em segundo lugar as estadunidenses e, por último, as brasileiras.

Suzigan et al. (2003) apresentaram o Índice de Gini como uma metodologia específica para identificar e delimitar geograficamente sistemas locais de produção, com aplicação ilustrativa à indústria de calçados do Estado de São Paulo. Os resultados apontaram a existência de três importantes sistemas locais de produção de calçados no Estado. Nesta pesquisa tal constatação não ocorreu quanto à distribuição das accruals discricionárias em razão dos resultados terem sido muito próximos para as empresas dos três países.

Os resultados desta pesquisa permitem colaborar com os achados de pesquisas anteriores na área de gerenciamento de resultados, tais como a de Healy (1985), Scheapper (1989), Burgstahler e Dichev (1997), Dechow e Skinner (2000), Martinez (2001), Gunny (2005), Bergstressera e Philippon (2006), Cohen e Zarowin (2008) e Basiruddin (2011), de que a gestão de resultados é uma realidade nas organizações. Inclui-se nesses achados que o gerenciamento de resultados pode ser nas modalidades de atividades operacionais ou de accruals discricionárias.

\subsection{POLÍTICA DE REMUNERAÇÃO DOS EXECUTIVOS VERSUS NÍVEL DE GERENCIAMENTO DE RESULTADOS}

Nesta seção apresentam-se os resultados das correlações canônicas. Técnica da estatística multivariada escolhida por permitir, conforme Fávero et al. (2009, 520), "a maximização da correlação entre 
as composições lineares das variáveis”. Lattin, Carroll e Green (2011, p. 255) defendem que esta técnica admite "explicar a variação observada em um conjunto de variáveis (designadas variáveis dependentes) usando as informações de outro conjunto de variáveis (designadas variáveis independentes)".

As variáveis do primeiro conjunto compreenderam os percentuais representativos da política de remuneração dos executivos, segregada em salário, bônus, remuneração baseada em ações e outras remunerações. Seus valores de entrada no modelo foram transformados em média por empresa, ou seja, a remuneração total de cada verba remuneratória dividida pelo número de executivos da diretoria. Os valores das remunerações por ano, e país, estão apresentados na seção 4.2 deste trabalho, que trata da política de remuneração, nas perspectivas de nível e de estrutura.

As variáveis do segundo conjunto de entrada no modelo consistem dos valores do gerenciamento de resultados por meio de: a) atividades operacionais, despesas com vendas e nível de produção; b) accruals discricionárias.

De posse das variáveis resultantes das etapas anteriores da pesquisa, política de remuneração dos executivos e dos níveis de gerenciamento de resultados, decorre a mensuração da relação entre estas, por meio de correlação canônica para as empresas industriais brasileiras, estadunidenses e inglesas.

\subsubsection{Empresas Industriais Brasileiras}

Na correlação canônica calculada para as empresas industriais brasileiras da amostra, foi analisado o montante de informações coletadas, ou seja, a partir deste ponto, a análise não é mais descrita por ano, como nos itens 4.1 a 4.4 desta pesquisa, mas sim em conjunto para o período de 2007 a 2010, pois o alcance do objetivo proposto independe do período, mas depende da quantidade de observações. As variáveis do modelo estão descritas no Quadro 21.

\begin{tabular}{|l|l|}
\hline Variáveis do conjunto 1 & \multicolumn{1}{|c|}{ Variáveis do conjunto 2 } \\
\hline$\%$ de salários & GRAO - DVGA \\
\hline$\%$ de bônus & GRAO - NP \\
\hline$\%$ de outras remunerações & GR por accruals discricionárias \\
\hline
\end{tabular}

Quadro 21 - Variáveis da correlação canônica - Brasil

Fonte: Dados da pesquisa. 
Conforme o Quadro 21, para a correlação canônica das empresas industriais brasileiras da amostra não foi possível incluir todas as variáveis previstas na pesquisa, pois houve uma relação linearmente dependente entre as variáveis da política de remuneração dos executivos.

Para possibilitar a efetivação do cálculo da correlação canônica foi excluída a variável dependente $\%$ da remuneração em ações, que representava $6,42 \%$ da política de remuneração total dos executivos das empresas industriais brasileiras da amostra analisada. Na Tabela 40 descrevem-se as funções canônicas.

\section{Tabela 40 - Correlações canônicas entre a PRE e o GR - BRA}

\begin{tabular}{c|c|c|c|c}
\hline $\begin{array}{c}\text { Função } \\
\text { Canônica }\end{array}$ & Eigenvalue & $\begin{array}{c}\text { Correlação } \\
\text { canônica }\end{array}$ & Wilks Lambda & P-Value \\
\hline 1 & 0,19352 & 0,439909 & 0,797528 & 0,0019 \\
2 & 0,00927965 & 0,096331 & 0,988899 & 0,8632 \\
3 & 0,00183802 & 0,0428722 & 0,998162 & 0,6448 \\
\hline
\end{tabular}

Fonte: Dados da pesquisa.

Na Tabela 40 observam-se as combinações lineares dos dois conjuntos de variáveis que têm a mais alta correlação entre eles, neste caso, três conjuntos lineares foram formados.

O primeiro conjunto, ou função canônica 1, é a que possui maior poder de explicação, 43,99\%. Esta correlação é estatisticamente significativa ao nível de $95 \%$, pois o p-value foi inferior a $5 \%$.

Realizou-se o mesmo teste incluindo a variável retirada e excluindo a variável \% de salário, mas a correlação canônica não se alterou, nem mesmo o P-value.

Este fato significa que estas duas variáveis não são relevantes nesta correlação, ou seja, é indiferente a presença de uma ou outra, para a ocorrência do gerenciamento de resultados nas modalidades analisadas.

Na Tabela 41 apresentam-se os valores resultantes dos dois conjuntos de inputs do modelo, que compreende 30 empresas e 4 anos, totalizando 120 observações. 
Tabela 41 - Coeficientes do modelo de correlação canônica - BRA

Coeficientes de variáveis canônicas do primeiro conjunto

\begin{tabular}{l|r|r|r}
\hline \multicolumn{1}{c|}{ Variável } & \multicolumn{1}{c|}{ Função 1 } & Função 2 & \multicolumn{1}{c}{ Função 3 } \\
\hline \% salários & 0,372091 & 3,69232 & $-4,53006$ \\
\% bônus & $-0,349327$ & 2,94045 & $-4,75424$ \\
\% outras & $-0,55608$ & 1,36444 & $-0,429805$ \\
\hline
\end{tabular}

Coeficientes de variáveis canônicas do segundo conjunto

\begin{tabular}{l|c|c|c}
\hline \multicolumn{1}{c|}{ Variável } & Função 1 & Função 2 & Função 3 \\
\hline GRAO DVGA & $-0,123852$ & $-0,0599451$ & 0,994397 \\
GRAO NP & 0,990805 & $-0,0521052$ & 0,125579 \\
GR Accruals & & & \\
scricionárias & 0,0671581 & 1,00148 & $-0,0199535$ \\
\hline
\end{tabular}

Fonte: Dados da pesquisa.

Na Tabela 41 evidencia-se a correlação estimada entre cada conjunto de variáveis canônicas. Ressalta-se que apenas o primeiro conjunto tem significância estatística ao nível de confiança de $95 \%$. Este resultado obtido, para a relação entre a política de remuneração dos executivos e o nível de gerenciamento de resultados por atividades operacionais e accruals discricionárias, das empresas industriais brasileiras da amostra analisada, corroboram com estudos anteriores, como o de Cardoso e Martinez (2006). Os autores investigaram empresas brasileiras listadas na BM\&FBovespa, e concluíram que estas gerenciam resultados por atividades operacionais ou por accruals discricionárias.

Os resultados da pesquisa também corroboram com os achados da pesquisa de Healy (1985), de que o plano de remuneração influencia a prática de gerenciamento de resultados. Acresce-se a estes resultados de pesquisas anteriores que, a efetivação da prática de gerenciamento de resultados pode ser por atividades operacionais; despesas com vendas, gerais e administrativas e nível de produção; ou por accruals discricionárias. Além disso, que este influencia o plano de remuneração do executivo das empresas industriais brasileiras investigadas.

\subsubsection{Empresas Industriais Estadunidenses}

Na correlação canônica calculada para as empresas industriais estadunidenses da amostra, foi analisado o período de 2007 a 2010. As variáveis do modelo estão descritas no Quadro 22. 


\begin{tabular}{|l|l|}
\hline Variáveis do conjunto 1 & \multicolumn{1}{c|}{ Variáveis do conjunto 2 } \\
\hline \% de salários & $\begin{array}{l}\text { Gerenciamento de resultados por atividades } \\
\text { operacionais - despesas com vendas, gerais e } \\
\text { administrativas }\end{array}$ \\
\hline \% de bônus & $\begin{array}{l}\text { Gerenciamento de resultados por atividades } \\
\text { operacionais - nível de produção }\end{array}$ \\
\hline $\begin{array}{l}\text { \% de remuneração baseada } \\
\text { em ações }\end{array}$ & Gerenciamento de resultados por accruals totais \\
\hline \% de outras remunerações & \\
\hline
\end{tabular}

\section{Quadro 22 - Variáveis da correlação canônica - Estados Unidos}

Fonte: Dados da pesquisa.

Observa-se no Quadro 22 que, para a correlação canônica das empresas industriais estadunidenses, foi possível incluir todas as variáveis previstas na pesquisa relativas à política de remuneração dos executivos.

$\mathrm{Na}$ Tabela 42 descrevem-se as funções canônicas entre política de remuneração dos executivos e gerenciamento de resultados para as empresas industriais estadunidenses.

Tabela 42 - Correlações canônicas entre PRE e GR - EUA

\begin{tabular}{c|c|c|c|c}
\hline $\begin{array}{c}\text { Função } \\
\text { Canônica }\end{array}$ & Eigenvalue & $\begin{array}{c}\text { Correlação } \\
\text { canônica }\end{array}$ & $\begin{array}{c}\text { Wilks } \\
\text { Lambda }\end{array}$ & P-Value \\
\hline 1 & 0,0231829 & 0,152259 & 0,971101 & 0,0002 \\
2 & 0,00490553 & 0,0700395 & 0,994148 & 0,2726 \\
3 & 0,000951256 & 0,0308424 & 0,999049 & 0,5420 \\
\hline
\end{tabular}

Fonte: Dados da pesquisa.

$\mathrm{Na}$ Tabela 42 verificam-se as combinações lineares dos dois conjuntos de variáveis que têm a mais alta correlação entre eles, em que três conjuntos lineares foram formados. O primeiro conjunto, ou função canônica 1, é o que possui o maior poder de explicação, 15,22\%. Este é estatisticamente significativo ao nível de $95 \%$, pois o $\mathrm{p}$-value foi inferior a $5 \%$.

Na Tabela 43 descrevem-se os valores resultantes do conjunto de inputs do modelo, que compreende 323 empresas e os dados relativos aos quatro anos, totalizando 1.292 observações. 
Tabela 43 - Coeficientes do modelo de correlação canônica - EUA

Coeficientes de variáveis canônicas do primeiro conjunto

\begin{tabular}{l|r|r|r}
\hline \multicolumn{1}{c|}{ Variável } & \multicolumn{1}{c|}{ Função 1 } & \multicolumn{1}{c|}{ Função 2 } & Função 3 \\
\hline \% salários & $-0,02199$ & $-0,2016$ & 1,19439 \\
\% bônus & 3,67994 & 0,808627 & 0,539099 \\
\% ações & $-2,91758$ & 0,648795 & $-0,868993$ \\
\% outras & $-0,0386766$ & $-0,899338$ & $-0,229071$ \\
\hline
\end{tabular}

Coeficientes de variáveis canônicas do segundo conjunto

\begin{tabular}{l|r|r|r}
\hline \multicolumn{1}{c|}{ Variável } & Função 1 & Função 2 & Função 3 \\
\hline GRAO DVGA & 0,128368 & 0,168899 & 0,986817 \\
GRAO NP & $-0,0721572$ & 0,971192 & $-0,244269$ \\
GR Accruals & & & \\
discricionárias & 1,00565 & 0,0302706 & $-0,0238062$ \\
\hline
\end{tabular}

Fonte: Dados da pesquisa.

Na Tabela 43 apresenta-se a correlação estimada entre cada conjunto de variáveis canônicas. Apenas o conjunto 1 tem significância estatística ao nível de confiança de $95 \%$. Este resultado obtido, para a relação entre a política de remuneração dos executivos e o nível de gerenciamento de resultados por atividades operacionais e accruals discricionárias, das empresas estadunidenses da amostra analisada, permite corroborar com estudos anteriores, como o de Zang (2005). A autora evidenciou, com base em análise de ampla amostra de empresas estadunidenses, de que estas gerenciam resultados por manipulação de atividades operacionais antes de gerenciar por manipulação de accruals discricionárias. Nesta pesquisa, a sequência da efetivação da prática de manipulação entre ambas as modalidades não foi objeto de estudo. Entretanto, confirmou-se que há gerenciamento de resultados em ambas as modalidades, nas empresas indústrias estadunidenses pesquisadas.

Kalyta (2009) evidenciou o impacto dos planos de pensão de CEOs estadunidenses em accruals discricionárias. Nesta pesquisa, foi avaliado o plano de remuneração de forma completa, não apenas a remuneração relacionada aos planos de aposentadoria. No entanto, é possível acrescer aos achados do autor que a prática de gerenciamento de resultados pode se efetivar por atividades operacionais; despesas com vendas, gerais e administrativas e nível de produção; ou por accruals discricionárias. Além disso, que gerenciamento de resultados influencia o plano de remuneração dos executivos que atuam nas empresas indústrias estadunidenses analisadas. 


\subsubsection{Empresas Industriais Inglesas}

Na correlação canônica calculada para as empresas industriais inglesas da amostra, foi analisado o período de 2007 a 2010. As variáveis do modelo estão descritas no Quadro 23.

\begin{tabular}{|l|l|}
\hline Variáveis do conjunto 1 & \multicolumn{1}{c|}{ Variáveis do conjunto 2 } \\
\hline \% de salários & $\begin{array}{l}\text { Gerenciamento de resultados por atividades } \\
\text { operacionais - despesas com vendas, gerais e } \\
\text { administrativas }\end{array}$ \\
\hline \% de bônus & $\begin{array}{l}\text { Gerenciamento de resultados por atividades } \\
\text { operacionais - nível de produção }\end{array}$ \\
\hline \% de outras remunerações & $\begin{array}{l}\text { Gerenciamento de resultados por accruals } \\
\text { discricionárias }\end{array}$ \\
\hline
\end{tabular}

\section{Quadro 23 - Variáveis da correlação canônica - Inglaterra}

Fonte: Dados da pesquisa.

Verifica-se no Quadro 23 que para a correlação canônica das empresas industriais inglesas não foi possível incluir todas as variáveis previstas na pesquisa. Foi excluída a variável dependente $\%$ de remuneração baseada em ações, que corresponde, em média, a 4,54\% da remuneração total dos executivos deste país. A correlação retornou que, com todas as variáveis previstas houve dependência linear entre as variáveis da política de remuneração dos executivos, inviabilizando a análise.

Na Tabela 44 descrevem-se as funções canônicas entre PRE e GR das empresas inglesas.

\section{Tabela 44 - Correlações canônicas entre PRE e GR - ING}

\begin{tabular}{c|r|r|r|r}
\hline $\begin{array}{c}\text { Função } \\
\text { Canônica }\end{array}$ & Eigenvalue & $\begin{array}{c}\text { Correlação } \\
\text { canônica }\end{array}$ & $\begin{array}{c}\text { Wilks } \\
\text { Lambda }\end{array}$ & P-Value \\
\hline 1 & 0,0102125 & 0,101057 & 0,983344 & 0,9610 \\
2 & 0,00620676 & 0,078783 & 0,99349 & 0,8783 \\
3 & 0,000305123 & 0,0174678 & 0,999695 & 0,8129 \\
\hline
\end{tabular}

Fonte: Dados da pesquisa.

Na Tabela 44 observam-se as combinações lineares dos dois conjuntos de variáveis que têm a mais alta correlação entre eles, neste caso, três conjuntos lineares foram formados. O primeiro conjunto, ou 
função canônica 1, é o que possui o maior poder de explicação, 10,10\%. No entanto, esta correlação não é estatisticamente significativa ao nível de $95 \%$, pois o p-value foi superior a $5 \%$.

Adicionalmente foram realizados testes com exclusões de algumas variáveis, que resultaram em:

a) excluindo-se as variáveis \% de remuneração em ações e \% de outras remunerações, a correlação canônica resultou em $9,87 \%$ e não teve significância estatística ao nível de confiança de $95 \%$;

b) mantendo apenas a variável \% de bônus no conjunto da política de remuneração dos executivos ingleses da amostra a correlação canônica resultou em $7,92 \%$ e não teve significância estatística ao nível de confiança de $95 \%$;

c) excluindo a variável \% de salário a correlação canônica resultou em 10,10\% e não teve significância estatística ao nível de confiança de $95 \%$. Obteve-se o mesmo índice de correlação quando da exclusão, inicialmente, da verba remuneração em ações. Isso significa que a presença de uma ou outra variável no conjunto da política de remuneração dos executivos das empresas inglesas da amostra é indiferente no relacionamento com o gerenciamento de resultados nas modalidades analisadas.

$\mathrm{Na}$ Tabela 45 verificam-se os valores resultantes do conjunto de inputs do modelo, que compreende 47 empresas e os dados dos quatro anos analisados, totalizando 188 observações.

\section{Tabela 45 - Coeficientes do modelo de correlação canônica - ING}

Coeficientes de variáveis canônicas do primeiro conjunto

\begin{tabular}{l|c|c|c}
\hline \multicolumn{1}{c|}{ Variável } & Função 1 & Função 2 & Função 3 \\
\hline \% salários & 4,75028 & $-8,72667$ & 1,51684 \\
\% bônus & 5,32914 & $-8,34032$ & 2,27626 \\
\% outras & 1,44465 & $-3,85929$ & 1,48496 \\
\hline
\end{tabular}

Coeficientes de variáveis canônicas do segundo conjunto

\begin{tabular}{l|c|c|c}
\hline \multicolumn{1}{c|}{ Variável } & Função 1 & Função 2 & Função 3 \\
\hline GRAO DVGA & 0,572717 & 0,768045 & 0,346952 \\
GRAO NP & $-0,698694$ & 0,226208 & 0,685667 \\
GR Accruals & & & \\
discricionárias & 0,395244 & $-0,789391$ & 0,518238 \\
\hline
\end{tabular}

Fonte: Dados da pesquisa. 
$\mathrm{Na}$ Tabela 45 verifica-se a correlação estimada entre cada conjunto de variáveis canônicas. Ressalta-se que nenhum dos conjuntos tem significância estatística ao nível de confiança de 95\%. Esse resultado obtido, para a relação entre a política de remuneração dos executivos e o nível de gerenciamento de resultados por manipulação de atividades operacionais e accruals discricionárias, das empresas inglesas da amostra analisada não permite confirmar a existência de relação entre as variáveis do estudo.

\subsubsection{Análise conjunta do BRA, EUA e INGL para a Política de Remuneração dos Executivos versus Nível de Gerenciamento de Resultados}

Comparando-se os Quadros 21, 22 e 23 verifica-se que a correlação canônica só pode ser calculada com todas as variáveis previstas na pesquisa para as empresas industriais estadunidenses. Para as brasileiras não pode ser incluída uma das variáveis, a opção pela exclusão foi para a verba denominada remuneração em ações, que representou, aproximadamente, $6,42 \%$ da remuneração total dos executivos deste país. Para as empresas industriais inglesas ocorreu a mesma situação, que inviabilizou o cálculo da correlação. A solução para a amostra deste país foi excluir uma variável. A opção pela exclusão da verba denominada remuneração em ações foi devido à baixa representatividade desta na remuneração total dos executivos deste país, em torno de $4,54 \%$.

A correlação canônica dos dois conjuntos de variáveis, o primeiro relativo à política de remuneração dos executivos e o segundo relativo ao gerenciamento de resultados por atividades operacionais, despesas com vendas, gerais e administrativas e atividades operacionais, nível de produção, também o gerenciamento de resultados por accruals discricionárias, resultou, com relação aos coeficientes dos três países, em maior índice para as empresas industriais do Brasil, com 43,99\%, contra 15,22\% dos Estados Unidos e 10,10\% da Inglaterra.

Os resultados da pesquisa revelaram que: a) para as empresas industriais brasileiras da amostra analisada, a correlação foi estatisticamente significativa, entretanto sem a variável $\%$ da remuneração em ações; b) para as empresas industriais estadunidenses da amostra analisada, a correlação foi estatisticamente significativa; c) para as empresas industriais inglesas da amostra analisada, a correlação, mesmo com diferentes testes e com exclusão de variáveis, não foi 
estatisticamente significativa, mas o principal teste apresentado foi sem a variável \% da remuneração em ações.

Com base nos resultados dos testes de significância estatística, resultantes das correlações canônicas apresentadas, é possível responder ao grupo I de hipóteses da pesquisa: política de remuneração do executivo; e gerenciamento de resultados por meio de atividades operacionais e accruals discricionárias. As cinco hipóteses verificadas têm seus resultados comentados a seguir.

Para a hipótese geral do estudo, $\mathrm{H}_{1}$, que há relação entre a política de remuneração do executivo e o nível de gerenciamento de resultados, com base nos resultados das correlações canônicas apresentados para os três países é possível aceitá-la, pois há significância estatística para a relação encontrada no teste realizado para as empresas industriais brasileiras e estadunidenses. Assim, se rejeita a hipótese nula de $\mathrm{H}_{1}$, ou seja, de que não há relação entre a política de remuneração de executivos e o gerenciamento de resultados por meio de atividades operacionais e por accruals discricionárias para a amostra analisada destes dois países. Testes adicionais realizados com a remuneração variável, composta de bônus e ações, substituindo a política de remuneração, validou apenas a relação entre a remuneração variável e o gerenciamento de resultados para os executivos brasileiros das empresas industriais pesquisadas.

Assim, são fortalecidos pelos resultados deste estudo, as afirmações de: (i) Dechow, Huson e Sloan (1994), de que o CEO é suscetível a tomar decisões sobre reestruturar as operações da empresa, (ii) Murphy (1999), de que os CEOs compreendem como suas ações afetam os lucros contábeis, (iii) Mcnichols e Wilson (1988), de que os resultados contábeis são manipulados por accruals discricionárias.

Dos testes realizados verifica-se que a visão oportunista do CEO, exposta por Schipper (1989), no contexto das motivações contratuais e da remuneração do executivo, como mecanismo de vinculação que contribui na redução de conflitos, e da assimetria informacional, exposta por Jensen e Meckling (1976), se constitui em um dos incentivos para a prática de gerenciamento de resultados.

Fortalece-se também o defendido por Healy, Wahlen (1999), de que o executivo, de acordo com seus interesses, faz escolhas contábeis, como forma de efetivar a prática de gerenciamento de resultados, na expectativa de recompensas por seu desempenho. Também, o destacado por Healy (1985), DeAngelo (1986) e Shipper (1989), de que existem incentivos para o gestor efetivar as escolhas contábeis, em razão do seu plano de remuneração estar atrelado aos números contábeis. Ainda, este 
estudo revelou que além das escolhas contábeis, o executivo também faz escolhas por ações organizacionais para ajustar os recursos comprometidos com as atividades, e com os reflexos destes no resultado da empresa e na sua política de remuneração.

A associação da remuneração do executivo, por meio de bônus ao gerenciamento de resultados, destacadas por Guidry, Leone e Rock (1999) e Healy (1999), e por meio da remuneração baseada em ações, ressaltadas por Abbody e Kasznik (2000) e Bens et al. (2003), também encontraram confirmação nesta pesquisa, pois ambas as remunerações estão contidas na política de remuneração do executivo analisada.

O entendimento de Cardoso e Martinez (2006), de que as empresas gerenciam os números contábeis mediante decisões operacionais e escolhas contábeis, pode ser complementado no sentido de que este gerenciamento é influenciado pela política de remuneração do executivo.

O exposto por Healy (1985), de que os executivos remunerados com plano de bônus selecionam procedimentos contábeis que aumentem a sua remuneração, também foi confirmado. Principalmente pelo teste nas empresas industriais brasileiras, em que mesmo excluindo a parte fixa da política de remuneração do executivo, o índice de correlação e o nível de significância não se alteraram. Assim mantém-se a rejeição da hipótese nula e se aceita a hipótese alternativa, de que há relação entre a política de remuneração do executivo e o nível de gerenciamento de resultados.

O exposto na literatura por Healy (1985), Scheapper (1989), Hanlon, Rajgopal e Shevlin (2003), Bartov e Mohanram (2004), Zang (2005), Gunny (2005) e Laux e Laux, (2009), de que a política de remuneração dos executivos é um incentivo para a prática de gerenciamento de resultados e que pode se efetivar por meio de atividades operacionais e por accruals discricionárias foi confirmado por esta pesquisa.

Após a análise entre a relação da política de remuneração dos executivos e o nível de gerenciamento de resultados por atividades operacionais e accruals discricionárias, testada por meio da hipótese nula geral do estudo, seguem-se as hipóteses dos grupos I e II, que analisam de forma parcial a remuneração do executivo com o gerenciamento de resultados: primeiro com despesas com vendas, gerais e administrativas, após as despesas com pesquisa e desenvolvimento e por fim, o nível de produção, fechando as atividades operacionais pesquisadas; segundo com as accruals discricionárias. Os testes foram 
realizados para as empresas brasileiras, estadunidenses e inglesas da amostra, conforme segue.

Na Figura 17 demonstram-se as hipóteses do grupo I que foram elaboradas para esta pesquisa, indicando as que foram confirmadas com tracejado e com pontilhado as que não foram confirmadas.

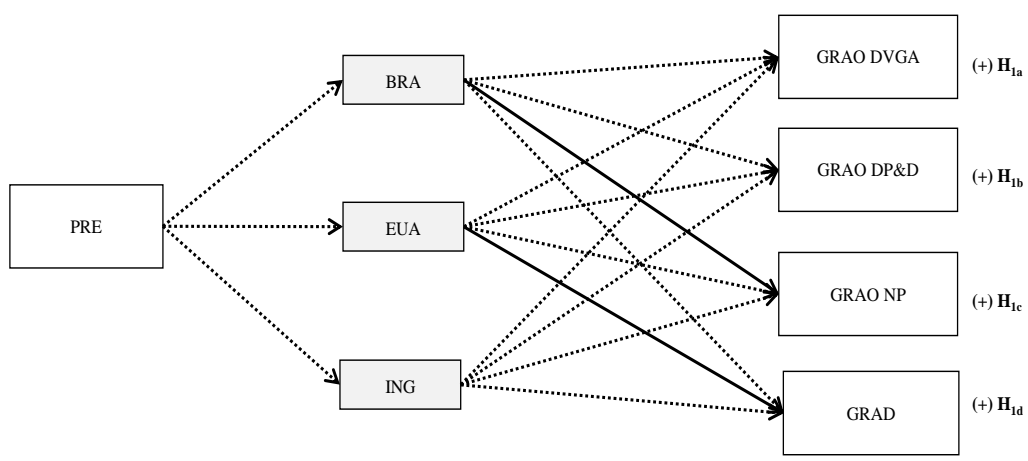

Figura 17 - Hipóteses confirmadas no Grupo I

Fonte: Elaboração própria.

Na Figura 17 observa-se que a hipótese $(+) \mathrm{H}_{1 \mathrm{c}}$, há relação positiva entre a política de remuneração do executivo e o nível de gerenciamento de resultados por meio de atividades operacionais, especificamente pelo nível de produção da empresa, foi confirmada para as empresas industriais brasileiras. Também a hipótese $\mathrm{H}_{1 \mathrm{~d}}$, há relação positiva entre a política de remuneração do executivo e o nível de gerenciamento de resultados por accruals discricionárias, foi confirmada para as empresas industriais estadunidenses. Todos os testes efetuados para verificação das hipóteses do Grupo I estão descritos a seguir.

Para testar a possibilidade de rejeição da hipótese nula de $\mathrm{H}_{1 \mathrm{a}}$, há relação positiva entre a política de remuneração dos executivos e o nível de gerenciamento de resultados por meio de atividades operacionais, especificamente despesas com vendas, despesas gerais e administrativas, foi utilizada a correlação canônica. Os resultados indicaram que, para as empresas industriais brasileiras, estadunidenses e inglesas não é possível rejeitar a hipótese nula, portanto não é possível rejeitar também $\mathrm{H}_{1 \mathrm{a}}$.

Os resultados da correlação canônica indicaram sinal positivo e correlação fraca. Para as empresas do Brasil 6,92\%, para as dos Estados Unidos 3,45\% e para as da Inglaterra $8,16 \%$. Todas as correlações não 
apresentaram resultados estatísticos significativos ao nível de 95\%. Ressalta-se que foi necessário excluir da verificação a variável denominada remuneração baseada em ações para o Brasil e a Inglaterra.

Portanto, os testes são inconclusivos, há tendência de que haja relação entre a política de remuneração dos executivos e o nível de gerenciamento de resultados por meio de atividades operacionais, especificamente despesas com vendas e despesas gerais e administrativas, para a amostra analisada.

As despesas com vendas, gerais e administrativas estudadas por Anderson, Banker e Janakiramam (2003), além de variarem de acordo com as circunstâncias e não pela atividade, também são associadas à política de remuneração do executivo, mas apenas conjuntamente com outras modalidades de gerenciamento de resultados, isoladamente não é possível definir.

Segue-se a terceira hipótese do grupo $\mathrm{I}, \mathrm{H}_{1 \mathrm{~b}}$, de que há relação positiva entre a política de remuneração do executivo e o nível de gerenciamento de resultados por meio de atividades operacionais, especificamente despesas com pesquisa e desenvolvimento. Não foi possível testar a hipótese $\mathrm{H}_{1 \mathrm{~b}}$, pois o objetivo específico estabelecido para a mesma não foi efetivado ao longo da pesquisa.

Segue-se a quarta hipótese do grupo I, que encerra o teste sobre o gerenciamento de resultados por atividades operacionais neste grupo, $\mathrm{H}_{1 c}$, de que há relação positiva entre a política de remuneração dos executivos e o nível de gerenciamento de resultados por meio de atividades operacionais, especificamente pelo nível de produção da empresa.

Para testar a possibilidade de rejeição da hipótese nula de $\mathrm{H}_{1 \mathrm{c}}$ foi utilizada a técnica multivariada de correlação canônica, que indicou que, para as empresas industriais brasileiras, se rejeita a hipótese nula e para as estadunidenses e inglesas não é possível a refutação da hipótese nula de $\mathrm{H}_{1 \mathrm{c}}$.

Os resultados da correlação canônica indicaram sinal positivo e correlação fraca. Para as empresas do Brasil 43,59\%, para as dos Estados Unidos 6,94\% e para as da Inglaterra 6,86\%. Como houve significância estatística ao nível de $95 \%$ apenas para as empresas industriais brasileiras da amostra, pode-se afirmar que para estas há relação positiva entre a política de remuneração dos executivos e o nível de gerenciamento de resultados por meio de atividades operacionais, especificamente pelo nível de produção da empresa. Ressalta-se que foi necessário excluir da verificação a variável denominada remuneração em ações para as empresas brasileiras, bem como para a Inglaterra. 
Portanto, as consequências da manipulação de atividades operacionais destacadas por Gunny (2005), com alterações nos resultados contábeis e, também, implicações das decisões de absorção de custos de produção, ressaltadas por Gupta, Pevzner e Seethamraju (2005), são confirmadas por esta pesquisa, dado a significância do teste de hipóteses das empresas industriais brasileiras.

Segue-se a última hipótese do grupo $\mathrm{I}, \mathrm{H}_{1 \mathrm{~d}}$, de que há relação positiva entre a política de remuneração dos executivos e o nível de gerenciamento de resultados por accruals discricionárias.

Para testar a possibilidade de rejeição da hipótese nula de $\mathrm{H}_{1 \mathrm{~d}}$ foi utilizada a técnica multivariada de correlação canônica, que indicou que, para as empresas industriais estadunidenses se rejeita a hipótese nula de $\mathrm{H}_{1 \mathrm{~d}}$ com um p-value de 0,0000 . Assim, para estas há relação positiva entre a política de remuneração dos executivos e o nível de gerenciamento de resultados por accruals discricionárias, com uma correlação canônica positiva de $1,5 \%$.

Em contrapartida, para as empresas industriais estadunidenses e inglesas não é possível rejeitar a hipótese nula de $\mathrm{H}_{1 \mathrm{~d}}$. Os resultados da correlação canônica indicaram sinal positivo com 9,80\% para as empresas do Brasil e 6,68\% para as da Inglaterra, mas não houve significância estatística ao nível de $95 \%$. Ressalta-se que foi necessário excluir da verificação a variável denominada remuneração baseada em ações para as empresas do Brasil e da Inglaterra.

Havendo rejeição da hipótese nula se aceita a hipótese de que há relação positiva entre a política de remuneração dos executivos e o nível de gerenciamento de resultados por gerenciamento de resultados por accruals discricionárias, que ocorreu apenas para as empresas industriais brasileiras. Para as empresas estadunidenses e inglesas o resultado é inconclusivo.

Para a verificação das hipóteses do grupo II, remuneração em dinheiro contida na política de remuneração dos executivos no Brasil, Estados Unidos da América e Inglaterra, são necessários valores apresentados anteriormente, tais como: o percentual relativo à remuneração em dinheiro dos executivos que atuam nas empresas industriais dos três países e dos valores de gerenciamento de resultados. Ambos os valores se encontram expostos na Tabela 46. 


\begin{tabular}{|c|c|c|c|}
\hline Médias / Países & BRA & EUA & ING \\
\hline $\begin{array}{l}\text { Média da remuneração em } \\
\text { dinheiro }\end{array}$ & 0,983935731 & 0,667105563 & 0,899721162 \\
\hline Média do GRAO DVGA & $-0,000003949$ & 0,000741856 & 0,000101875 \\
\hline $\begin{array}{l}\text { Média do GRAO NP } \\
\text { Média do GR Accruals } \\
\text { discricionárias }\end{array}$ & $\begin{array}{r}-0,000243243 \\
0,016869124\end{array}$ & $\begin{array}{r}-0,000161257 \\
0,043157346\end{array}$ & $\begin{array}{l}0,000213084 \\
0,007878467\end{array}$ \\
\hline
\end{tabular}

Fonte: Dados da pesquisa.

Na Tabela 46 constam as médias das variáveis abrangidas no teste de hipóteses do grupo II, que são o percentual total da remuneração em dinheiro por país e o valor de gerenciamento de resultados por meio de atividades operacionais e por accruals discricionárias por país.

Verifica-se na Tabela 46 que as empresas do país que possui a maior remuneração em dinheiro são as do Brasil. Também que as empresas industriais dos Estados Unidos da América possuem o maior nível de gerenciamento de resultados por meio de atividades operacionais, despesas com vendas, gerais e administrativas.

Na Figura 18 evidenciam-se as hipóteses do grupo II, que foram elaboradas para esta pesquisa, indicando as que foram confirmadas com tracejado e com pontilhado as que não foram confirmadas.

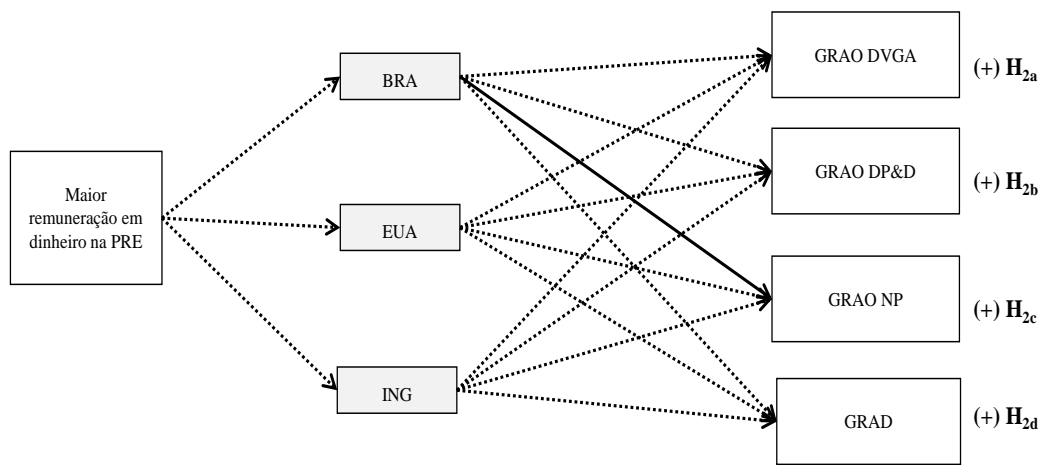

Figura 18 - Hipóteses confirmadas no Grupo II

Fonte: Elaboração própria.

Na Figura 18 ressalta-se que apenas a hipótese $(+) \mathrm{H}_{2 \mathrm{c}}$, países com maior remuneração em dinheiro contida na política de remuneração 
dos executivos possuem maior nível de gerenciamento de resultados por meio de atividades operacionais, especificamente pelo nível de produção da empresa, foi confirmada para as empresas industriais brasileiras. Os testes efetuados para verificação das hipóteses do Grupo II estão descritos a seguir.

A primeira hipótese do grupo II, $\mathrm{H}_{2 \mathrm{a}}$, de que países que possuem maior remuneração em dinheiro contida na política de remuneração dos executivos apresentam maior nível de gerenciamento de resultados por meio de atividades operacionais, especificamente despesas com vendas e despesas gerais e administrativas, o resultado da análise de correlação para verificação do sinal dos coeficientes e a significância estatística indicou que para as empresas industriais brasileiras, estadunidenses e inglesas analisadas não é possível rejeitar a hipótese nula de $\mathrm{H}_{2 \mathrm{a}}$, nem mesmo a refutação da hipótese alternativa. Os coeficientes foram positivos e não significativos ao nível de $95 \%$ de confiabilidade.

Desta forma, a hipótese de que países que possuem maior remuneração em dinheiro contida na política de remuneração dos executivos apresentam maior nível de gerenciamento de resultados por meio de atividades operacionais, especificamente despesas com vendas e despesas gerais e administrativas, é inconclusiva para as empresas industriais brasileiras, estadunidenses e inglesas da amostra analisada.

A segunda hipótese do grupo II, $\mathrm{H}_{2 b}$, de que países que possuem maior remuneração em dinheiro contida na política de remuneração dos executivos apresentam maior nível de gerenciamento de resultados por meio de atividades operacionais, especificamente despesas com pesquisa e desenvolvimento, não foi possível testá-la, pois o objetivo específico estabelecido para a mesma não foi efetivado ao longo da pesquisa.

A terceira hipótese do grupo II, $\mathrm{H}_{2 \mathrm{c}}$, de que países que possuem maior remuneração em dinheiro contida na política de remuneração dos executivos apresentam maior nível de gerenciamento de resultados por meio de atividades operacionais, especificamente pelo nível de produção da empresa, foi aceita.

Observa-se na Tabela 46 que as empresas do país que possuem a maior remuneração, média em dinheiro, na composição da política de remuneração do executivo, são do Brasil. Também, possuem o maior nível de gerenciamento de resultados negativo por meio de atividades operacionais, especificamente pelo nível de produção da empresa.

O resultado da análise de correlação canônica para verificação do sinal dos coeficientes e a significância estatística indicou que: 
a) para as empresas industriais brasileiras, o sinal do coeficiente foi positivo e significativo ao nível de $95 \%$ de confiabilidade. Então, se rejeita a hipótese nula e se aceita a hipótese alternativa de $\mathrm{H}_{2 \mathrm{c}}$;

b) para as empresas industriais estadunidenses, o sinal do coeficiente foi positivo e não significativo ao nível de $95 \%$ de confiabilidade. Devido à confiabilidade do modelo não é possível rejeitar a hipótese nula e nem mesmo a alternativa de $\mathrm{H}_{2 c}$;

c) para as empresas industriais inglesas, o sinal do coeficiente foi positivo e não significativo ao nível de $95 \%$ de confiabilidade. Assim, não é possível rejeitar a hipótese nula e nem mesmo a alternativa de $\mathrm{H}_{2 \mathrm{c}}$.

Desta forma, a hipótese de que países que possuem maior remuneração em dinheiro contida na política de remuneração dos executivos apresentam maior nível de gerenciamento de resultados por meio de atividades operacionais, especificamente pelo nível de produção da empresa, é válida apenas para as empresas industriais brasileiras, para as estadunidenses e inglesas é inconclusiva.

A quarta hipótese do grupo II, $\mathrm{H}_{2 \mathrm{~d}}$, de que países que possuem maior remuneração em dinheiro contida na política de remuneração dos executivos apresentam maior nível de gerenciamento de resultados por accruals discricionários foi inconclusiva.

Observam-se na Tabela 46 que as empresas do país que possui maior remuneração em dinheiro são as do Brasil. No entanto, as empresas industriais do Brasil não possuem o maior nível de gerenciamento de resultados por meio de accruals discricionárias. As empresas industriais que obtiveram a maior média são dos Estados Unidos da América.

O resultado da análise de correlação para verificação do sinal dos coeficientes e a significância estatística indicou que, para as empresas industriais brasileiras, estadunidenses e inglesas, o sinal do coeficiente foi positivo e não significativo ao nível de $95 \%$ de confiabilidade. Dessa forma, não é possível rejeitar a hipótese nula nem a alternativa de $\mathrm{H}_{2 \mathrm{~d}}$.

Portanto, a hipótese de que países que possuem maior remuneração em dinheiro contida na política de remuneração dos executivos apresentam maior nível de gerenciamento de resultados por meio de accruals discricionárias é inconclusiva para a amostra dos três países analisados. 
Foi testado também se a maior remuneração em dinheiro contida na política de remuneração dos executivos implica em maior gerenciamento de resultados conjuntamente nas duas modalidades, atividades operacionais (despesas com vendas, gerais e administrativas e nível de produção) e por accruals discricionárias. Os resultados da correlação indicaram sinal positivo, mas não estatisticamente significativos. Fato que permite confirmar os resultados da pesquisa de Gaver e Gaver (1998), de que o gerenciamento de resultados se reflete na remuneração em dinheiro do executivo, e aos achados da pesquisa de Comprix e Muller (2006) de que há associação entre o gerenciamento de resultados e a remuneração em dinheiro do executivo.

\subsection{ANÁLISE DA POLÍTICA DE REMUNERAÇÃO E NÍVEL DE GERENCIAMENTO DE RESULTADOS COM VARIÁVEIS ENDÓGENAS}

Nesta seção apresenta-se a análise da relação da política de remuneração dos executivos e do nível de gerenciamento de resultados, subdividindo a amostra de empresas industriais por variáveis endógenas relativas às características do executivo e da empresa.

As variáveis endógenas relativas às características dos executivos consideradas são: idade, expertise e gênero. As variáveis endógenas relativas às características das empresas consideradas são: homogeneidade e/ou segmento, desempenho, por meio do lucro e tamanho das empresas. As variáveis endógenas foram definidas e tiveram sua operacionalização descritas nos constructos da pesquisa, apresentados no item 3.4 desta tese.

Foi utilizada a técnica estatística multivariada de correlação canônica para verificar as influências geradas pela segregação da amostra pelas variáveis endógenas. As variáveis Y, ou dependentes, compreendem os percentuais representativos da política de remuneração dos executivos, segregada em salário, bônus, remuneração baseada em ações e outras remunerações. As variáveis $X$, ou independentes, de entrada no modelo foram os valores do gerenciamento de resultados por meio de: a) atividades operacionais, despesas com vendas e nível de produção; b) accruals discricionárias.

A partir dos resultados obtidos da relação entre a política de remuneração dos executivos e o nível de gerenciamento de resultados por atividades operacionais e accruals discricionárias, foram viabilizados os testes estatísticos com a amostra segregada pelas 
variáveis endógenas, características dos executivos e das empresas, para as empresas brasileiras, estadunidenses e inglesas.

\subsubsection{Empresas Industriais Brasileiras}

$\mathrm{Na}$ Tabela 47 descrevem-se as correlações canônicas obtidas para as empresas industriais brasileiras. Destaca-se que as correlações canônicas apresentadas resultaram das combinações lineares dos dois conjuntos de variáveis que têm a mais alta correlação entre eles. Dos três conjuntos lineares formados, apresentou-se apenas o primeiro conjunto ou função canônica 1, pois é o que evidenciou maior poder de explicação para todos os testes efetuados.

Tabela 47 - Correlações canônicas PRE e GR (variáveis endógenas) - BRA

\begin{tabular}{l|c|c|c}
\hline \multicolumn{1}{c|}{ Variáveis endógenas } & Observações & Cor. Canônica & P-value \\
\hline Total & 120 & 0,4399 & 0,0019 \\
\hline Características do executivo & & & \\
\hline \multicolumn{1}{c|}{ Idade } & 25 & 0,4677 & 0,6801 \\
Até 49 anos & 74 & 0,4759 & 0,0173 \\
De 50 a 65 anos & 20 & 0,6922 & 0,3319 \\
Mais de 65 anos $\quad$ Expertise & 60 & 0,5321 & 0,0033 \\
Grupo I - menor & 60 & 0,3890 & 0,1405 \\
Grupo II - maior & & & \\
Características da empresa & & & \\
\hline \multicolumn{1}{c|}{ Segmento } & 23 & 0,4452 & 0,6140 \\
Siderurgia e metalurgia & 19 & 0,7517 & 0,0475 \\
Têxtil Desempenho & & & \\
Menor & 71 & 0,3933 & 0,1398 \\
Maior Tamanho & 49 & 0,5087 & 0,0242 \\
Empresas menores & 70 & 0,3946 & 0,0646 \\
Empresas maiores & 50 & 0,4982 & 0,1461 \\
\hline
\end{tabular}

Fonte: Dados da pesquisa.

Verifica-se na Tabela 47 que o total de observações analisadas para as empresas industriais brasileiras foi 120. Esse valor se origina da 
observação de 30 empresas, e os dados do período de quatro anos, de 2007 a 2010. A correlação canônica para todas as observações da amostra foi de $43,99 \%$ e se apresentou significativa, pois o p-value foi inferior a 0,05 para o intervalo de confiança de $95 \%$.

A segregação da amostra das empresas industriais brasileiras pelas variáveis endógenas, características dos executivos, indicou que:

a) relativamente à idade, a maior parte das observações se concentrou na segunda faixa etária, ou seja, na idade entre 50 e 65 anos. Nota-se que para esta faixa etária a correlação resultante foi de $47,59 \%$, ou seja, maior do que a correlação das observações totais para estas empresas industriais. Também, cabe destacar que esta faixa etária foi a única que obteve significância estatística, pois o p-value foi inferior a $5 \%$. Adicionalmente informa-se que as três faixas somaram 119 observações, pois 1 observação, ou seja, 1 empresa em um ano não informou a idade do seu diretor presidente executivo;

b) com relação à expertise, ressalta-se que esta foi segregada em formação, tempo de experiência de trabalho e certificação profissional. A formação compreende $1^{\text {a }}$ graduação, $2^{\mathrm{a}}$ graduação, especialização, mestrado e doutorado. Depois de somados os índices de expertise, conforme definidos nos constructos desta pesquisa e segregados em dois grupos pela mediana da amostra, obteve-se um grupo de menor expertise e outro grupo de maior expertise. $\mathrm{O}$ grupo de menor expertise apresentou maior correlação, 53,21\%, do que o de menor expertise, $38,9 \%$. Destaca-se que este último não apresentou um pvalue estatisticamente significativo ao nível de confiança de $95 \%$;

c) sobre o gênero não foi possível calcular a correlação, pois dentre os 120 executivos pesquisados, apenas 4 são do gênero feminino, fato que não permitiu a viabilização de testes estatísticos para a amostra objeto do estudo.

A segregação da amostra das empresas industriais brasileiras pelas variáveis endógenas, características das empresas, demonstrou que:

a) sobre a homogeneidade da indústria, observado pelo segmento de atuação das mesmas, apenas as atividades de 
siderurgia e metalurgia e o setor têxtil, obtiveram a viabilização do cálculo da correlação canônica, somando 42 observações. Nota-se que a correlação se apresentou superior para o setor têxtil, com $75,17 \%$. Também que obteve um p-value inferior a 0,05 , confirmando que o resultado do modelo testado para esta amostra parcial é estatisticamente significativo ao nível de $95 \%$ de confiança;

b) em relação ao desempenho da empresa, mensurado pelo valor do lucro divulgado nas demonstrações contábeis das empresas industriais brasileiras da amostra, observa-se que dentre os dois grupos formados pela segregação da amostra, apenas o grupo de maiores lucros teve significância estatística e uma correlação de 50,87\%;

c) relativamente ao tamanho da empresa, mensurado pelo total dos ativos de cada ano, dois grupos foram formados a partir do cálculo da mediana da amostra. A maior correlação foi para o grupo de empresas de grande porte, com 49,82\%. Entretanto, para nenhum dos dois grupos houve significância estatística nos testes realizados.

Ao fim dos testes relativos à segregação da amostra de empresas industriais brasileiras, pelos critérios definidos nas variáveis endógenas, foi possível observar que uma característica do executivo (expertise) e duas características da empresa (segmento e desempenho) foram relevantes no estudo da relação entre a política de remuneração dos executivos e o nível de gerenciamento de resultados dessas empresas. Tal segregação alterou os valores das correlações e dos valores de significância do modelo, obtidos inicialmente.

Corroborando a ideia da relevância dessas variáveis endógenas, como na pesquisa de Aier et al. (2005), que incluiu a variável expertise do executivo; de Dechow, Richardson e Tuna (2003) e de Farrel e Whidbee (2003), que incluíram a variável segmento da empresa em suas pesquisas; e, na pesquisa de Murphy (1999), que incluiu a variável desempenho da empresa.

\subsubsection{Empresas Industriais Estadunidenses}

Os valores obtidos para as correlações canônicas das empresas industriais estadunidenses analisadas. Estão apresentadas na Tabela 48, Cabe salientar que as relações apresentadas são decorrentes das 
combinações lineares dos dois conjuntos de variáveis que têm a mais alta correlação entre eles. Dos três conjuntos lineares formados, apresentou-se apenas a primeira função canônica, pois é a que apresentou maior poder de explicação para todos os testes efetuados.

Tabela 48 - Correlações canônicas PRE e GR (variáveis endógenas) - EUA

\begin{tabular}{l|c|c|c}
\hline \multicolumn{1}{c|}{ Variáveis endógenas } & Observações & Cor. Canônica & P-value \\
\hline Total Características do & 1.292 & 0,1522 & 0,0002 \\
\hline \multicolumn{1}{c|}{ Idade } & & & \\
\hline $\begin{array}{l}\text { Até 49 anos } \\
\text { De 50 a 65 anos }\end{array}$ & 201 & 0,1916 & 0,2120 \\
Mais de 65 anos $\quad 853$ & 0,1686 & 0,0007 \\
$\quad$ Expertise & 229 & 0,1772 & 0,5009 \\
Grupo I - menor & & & \\
Grupo II - maior & 508 & 0,1601 & 0,0116 \\
$\quad$ Características da & 784 & 0,1655 & 0,0101 \\
$\quad$ empresa & & & \\
$\quad$ Segmento & & & \\
Construção & 72 & 0,2162 & 0,8028 \\
Eletroeletrônicos & 492 & 0,1612 & 0,0771 \\
Máquinas industriais & 252 & 0,2549 & 0,0072 \\
Minerais não metálicos & 128 & 0,3688 & 0,0002 \\
Outros & 64 & 0,3724 & 0,2950 \\
Siderurgia e metalurgia & 100 & 0,2452 & 0,5757 \\
Equipamentos de transporte & 160 & 0,2044 & 0,1900 \\
$\quad$ Desempenho & & & \\
Menor & 676 & 0,1709 & 0,0016 \\
Maior Tamanho & 616 & 0,2237 & 0,0000 \\
Empresas menores & 643 & 0,1917 & 0,0039 \\
Empresas maiores & 649 & 0,1807 & 0,0000 \\
\hline Fone: Das da pesqisa & & &
\end{tabular}

Fonte: Dados da pesquisa.

Nota-se na Tabela 48 que no total foram analisadas 1.292 observações para as empresas industriais estadunidenses, relativas ao período de 2007 a 2010, oriundas de 323 empresas. A correlação 
canônica para todas as observações da amostra foi de $15,22 \%$ e se apresentou estatisticamente significativa, pois o p-value foi inferior a 0,05 para o intervalo de confiança de $95 \%$.

A segregação da amostra das empresas industriais estadunidenses em extratos pelas variáveis endógenas, características dos executivos, permitiu verificar que:

a) sobre a idade, a maior parte das observações se concentrou na segunda faixa etária, ou seja, na idade entre 50 e 65 anos. Nota-se que para esta faixa etária a correlação resultante foi de $16,86 \%$ e obteve significância estatística, pois o p-value foi inferior a 5\%. Embora, a maior correlação nesta segregação tenha sido de $19,16 \%$ para executivos de até 50 anos, esta faixa etária não obteve significância estatística no teste de correlação canônica. As três faixas somaram 1.283 observações, pois nove observações não tiveram a idade divulgada do Chief Executive Officer (CEO);

b) relativamente à expertise, ressalta-se que esta foi segregada em formação, tempo de experiência de trabalho e certificação profissional. A formação compreende $1^{\mathrm{a}}$ graduação, $2^{\text {a }}$ graduação, especialização, mestrado e doutorado. Depois de somados os índices de expertise, conforme definidos nos constructos desta pesquisa e segregados em dois grupos pela mediana da amostra, obteve-se um grupo de menor expertise e outro grupo de maior expertise. $\mathrm{O}$ grupo de maior expertise apresentou maior correlação, $16,55 \%$, do que o de menor expertise, $16,01 \%$. No entanto, ambos apresentaram p-value estatisticamente significativo ao nível de confiança de $95 \%$;

c) com relação ao gênero não foi possível calcular a correlação, pois dentre os 1.292 executivos pesquisados, apenas 4 são do gênero feminino, fato que não permitiu rodar os testes estatísticos para a amostra deste estudo.

A segregação da amostra das empresas industriais estadunidenses pelas variáveis endógenas, características da empresa, evidenciou que:

a) sobre a homogeneidade da indústria, observado pelo segmento de atuação das mesmas, as atividades de 
manufatura da construção, de eletroeletrônicos, de máquinas industriais, de minerais não metálicos, de outros bens não classificados, de siderurgia e metalurgia e de equipamentos de transporte, permitiram o cálculo da correlação canônica, somando 1.268 observações. Restaram apenas 24 observações em outras atividades não analisadas. Nota-se que a correlação se apresentou superior, primeiramente para outras atividades, com $37,24 \%$, em segundo lugar para os minerais não metálicos. Também que o coeficiente p-value inferior a 0,05 foi resultante das atividades de manufatura de máquinas industriais e minerais não metálicos;

b) em relação ao desempenho da empresa, mensurado pelo valor do lucro divulgado nas demonstrações contábeis das empresas industriais estadunidenses da amostra, observouse que os dois grupos formados pela segregação da amostra obtiveram significância estatística, apesar do grupo de maior desempenho apresentar a maior correlação, $33,37 \%$;

c) no que concerne ao tamanho e/ou porte da empresa, mensurado pelo total dos ativos de cada ano, dois grupos foram formados a partir do cálculo da mediana da amostra. A maior correlação foi para o grupo de empresas industriais de pequeno porte, com 19,17\%. Entretanto, para os dois grupos houve significância estatística nos testes realizados.

Ao término da efetivação dos testes relativos à segregação da amostra de empresas industriais estadunidenses, pelos critérios definidos nas variáveis endógenas, foi possível observar que duas características do executivo (idade e expertise) e três características da empresa (segmento, desempenho e porte) foram relevantes no estudo da relação entre a política de remuneração dos executivos e o nível de gerenciamento de resultados dessas empresas, pois tal segregação alterou a quantidade e a qualidade da associação entre as variáveis.

Desse modo, os resultados desta pesquisa apoiam a ideia de relevância dessas variáveis endógenas, como na pesquisa de Dechow e Sloan (1991), Murphy (1999), Engel, Hayes e Wang (2003) e Farrel e Whidbee (2003), que utilizaram a variável idade do executivo como explicativa em seus estudos; de Aier et al. (2005), que incluiram a variável expertise do executivo; de Dechow, Richardson e Tuna (2003), 
Farrel e Whidbee (2003), para a variável segmento de atuação da empresa; de Murphy (1999), para a variável desempenho da empresa; e, por fim, de Jensen e Murphy (1990), Mek, Rao e Skousen (2007) para a variável tamanho da empresa.

\subsubsection{Empresas Industriais Inglesas}

$\mathrm{Na}$ Tabela 49 apresentam-se os valores resultantes das correlações canônicas calculadas para as empresas industriais inglesas. Destaca-se que estão descritos os resultados para as combinações lineares dos dois conjuntos de variáveis que têm a mais alta correlação entre eles, que corresponde ao primeiro conjunto ou função canônica 1 , pois esta é a que possui o maior poder de explicação.

Tabela 49 - Correlações canônicas PRE e GR (variáveis endógenas)

- ING

\begin{tabular}{|c|c|c|c|}
\hline Variáveis endógenas & Observações & Cor. Canônica & P-value \\
\hline Total & 188 & 0,1010 & 0,9610 \\
\hline \multicolumn{4}{|l|}{ Características do executivo } \\
\hline \multicolumn{4}{|l|}{ Idade } \\
\hline Até 49 anos & 80 & 0,2773 & 0,4111 \\
\hline De 50 a 65 anos & 93 & 0,3445 & 0,0763 \\
\hline \multicolumn{4}{|l|}{ Expertise } \\
\hline Grupo I - menor & 79 & 0,2454 & 0,8514 \\
\hline Grupo II - maior & 109 & 0,3232 & 0,0746 \\
\hline \multicolumn{4}{|l|}{ Características da empresa } \\
\hline \multicolumn{4}{|l|}{ Segmento } \\
\hline Eletroeletrônicos & 60 & 0,3330 & 0,3719 \\
\hline Máquinas industriais & 44 & 0,3238 & 0,6182 \\
\hline Papel e celulose & 16 & 0,7447 & 0,1687 \\
\hline Siderurgia e metalurgia & 28 & 0,6771 & 0,0182 \\
\hline Equipamentos de transporte & 12 & 0,8590 & 0,0412 \\
\hline \multicolumn{4}{|l|}{ Desempenho } \\
\hline Menor & 106 & 0,2650 & 0,5065 \\
\hline Maior & 82 & 0,2836 & 0,4813 \\
\hline \multicolumn{4}{|l|}{ Tamanho } \\
\hline Empresas menores & 93 & 0,3117 & 0,3537 \\
\hline Empresas maiores & 95 & 0,2344 & 0,3878 \\
\hline
\end{tabular}

Fonte: Dados da pesquisa. 
Na Tabela 49 verificam-se as correlações canônicas obtidas para as 188 observações relativas as 47 empresas industriais inglesas, do período de quatro anos, de 2007 a 2010. A correlação canônica para todas as observações da amostra foi de $10,10 \%$ e não se apresentou estatisticamente significativa, pois o p-value foi superior a 0,05 para o intervalo de confiança de $95 \%$.

A primeira parte da Tabela 49 apresenta os resultados das correlações para a segregação da amostra das empresas industriais inglesas em extratos pelas variáveis endógenas, características dos executivos, analisados a seguir:

a) referente à idade do executivo, a maior parte das observações e a maior correlação, $34,45 \%$, se concentrou na segunda faixa etária, com idades entre 50 e 65 anos. Nenhum dos extratos obteve significância estatística no teste de correlação canônica. Nota-se que as três faixas somaram 173 observações, pois 15 observações não tiveram a idade divulgada do Chief Executive Officer (CEO);

b) a expertise foi segregada em formação, tempo de experiência de trabalho e certificação profissional. A formação compreende $1^{\mathrm{a}}$ graduação, $2^{\mathrm{a}}$ graduação, especialização, mestrado e doutorado. Depois de somados os índices de expertise, conforme definidos no constructo desta pesquisa e segregados em dois grupos pela mediana da amostra, obteve-se um grupo de menor expertise e outro grupo de maior expertise. $\mathrm{O}$ grupo de maior expertise apresentou maior correlação $32,32 \%$ do que o de menor expertise 24,54\%. No entanto, ambos os grupos apresentaram p-value estatisticamente não significativo ao nível de confiança de $95 \%$;

c) relativamente ao gênero dos executivos não foi viável o cálculo da correlação, pois dentre os 188 executivos pesquisados, apenas 4 são do gênero feminino, fato que não permitiu a viabilização de testes estatísticos para a amostra analisada.

A segunda parte da Tabela 49 apresenta os resultados das correlações para a segregação da amostra das empresas industriais inglesas em extratos pelas variáveis endógenas, características da empresa, analisados a seguir: 
a) sobre a homogeneidade da indústria, observado pelo segmento de atuação das mesmas, as atividades de fabricação de eletroeletrônicos, máquinas industriais, papel e celulose, siderurgia e metalurgia e equipamentos de transporte, viabilizaram o cálculo da correlação canônica, perfazendo um total de 160 observações. A correlação se apresentou superior no segmento de equipamentos de transporte, com $85,90 \%$, e o coeficiente p-value foi inferior a 0,05 . Foi significativa também a correlação para o segmento de papel e celulose;

b) em relação ao desempenho da empresa, mensurado pelo valor do lucro divulgado nas demonstrações contábeis das empresas industriais inglesas da amostra, ressalta-se que os dois grupos formados pela segregação da amostra não obtiveram significância estatística, apesar do grupo de maior desempenho apresentar a maior correlação, 38,46\%;

c) referente ao tamanho e/ou porte da empresa, mensurado pelo total dos ativos de cada ano, dois grupos foram formados a partir do cálculo da mediana da amostra. A maior correlação foi para o grupo de empresas industriais de grande porte, com 23,44\%. Entretanto, para os dois grupos não houve significância estatística nos testes realizados.

Ao término da efetivação dos testes relativos à segregação da amostra de empresas industriais inglesas, pelos critérios definidos nas variáveis endógenas, foi possível observar que apenas uma característica da empresa (segmento) foi relevante no estudo da relação entre a política de remuneração dos executivos e o nível de gerenciamento de resultados dessas empresas, pois tal segregação alterou a quantidade e a qualidade da associação entre as variáveis. Assim, esse resultado confirma a ideia de Dechow, Richardson e Tuna (2003) e de Farrel e Whidbee (2003), da relevância dessa variável, segmento de atuação da empresa, no contexto das pesquisas empíricas.

\subsubsection{Análise conjunta do BRA, EUA e ING para a Política de Remuneração dos Executivos e do Gerenciamento de Resultados com a amostra segregada pelas Variáveis Endógenas}

Comparando-se as Tabelas 47, 48 e 49, que apresentam as correlações canônicas calculadas para as variáveis, política de 
remuneração do executivo e gerenciamento de resultados, das empresas industriais brasileiras, estadunidenses e inglesas da amostra analisada, segregadas pelas variáveis endógenas características do executivo e características da empresa, podem-se fazer algumas considerações:

a) a idade do executivo, na faixa de 50 a 65 anos, modificou para mais o percentual de correlação nos três países. Nas empresas do Brasil a correlação foi maior do que para os outros países, 47,59\%, contra 16,86 dos Estados Unidos e $34,45 \%$ para as empresas inglesas;

b) a expertise do executivo, mensurada pela formação, experiência e certificação profissional, teve resultados semelhantes nos três países, pois aumentou o percentual da correlação inicial, sem a segregação da amostra em extratos. Nas empresas industriais brasileiras, a maior correlação foi para os executivos com menor expertise, $53,21 \%$, já para os estadunidenses e ingleses foi para os de maior expertise, $16,55 \%$ e $32,32 \%$, respectivamente;

c) o gênero dos executivos não teve viabilidade de cálculo das correlações, devido à baixa representatividade do gênero feminino na amostra nos três países;

d) a homogeneidade da indústria, analisada pelo segmento de atuação, teve preponderância na correlação do segmento têxtil nas empresas industriais brasileiras, com 75,17\%, nas estadunidenses o segmento de outros bens, seguido dos minerais não metálicos, com $37,24 \%$ e $36,88 \%$ de correlação respectivamente;

e) as atividades de fabricação de eletroeletrônicos, máquinas industriais, papel e celulose, siderurgia e metalurgia e equipamentos de transporte, viabilizaram o cálculo da correlação canônica, perfazendo um total de 160 observações. A correlação se apresentou superior no segmento de equipamentos de transporte, com $85,90 \%$, e o coeficiente p-value foi inferior a 0,05 . Foi significativa também a correlação para o segmento de papel e celulose

f) o desempenho da empresa, mensurado pelo valor do lucro, demonstrou maior correlação para a amostra analisada dos três países no grupo de maior desempenho. O Brasil teve maior correlação, $50,87 \%$, seguido pela Inglaterra, com $38,36 \%$, e os Estados Unidos, com 22,37\%. Ressalta-se 
que todas as correlações foram maiores do que sem a segregação da amostra em extratos;

g) o tamanho da empresa, mensurado pelos ativos totais, obteve resultados distintos entre as empresas industriais dos três países. Para as empresas industriais brasileiras a maior correlação foi para o grupo de grande porte, com 49,82\%; nas estadunidenses e inglesas a maior correlação encontrada foi para o grupo de pequeno porte, com $19,17 \%$ e $31,17 \%$ respectivamente, mesmo tendo menor quantidade de observações nesse grupo para ambos os países.

Na Figura 19 demonstram-se as hipóteses do grupo III, que foram elaboradas para esta pesquisa, indicando as que foram confirmadas com tracejado e com pontilhado as não confirmadas. Destaca-se que a verificação das hipóteses para as empresas industriais brasileiras e inglesas desconsiderou a verba denominada remuneração em ações e para as estadunidenses a verba denominada outras remunerações, pois houve dependência linear entre as variáveis, inviabilizando os testes. Desta forma, a exclusão foi pela verba que representou o menor percentual da política de remuneração de cada país.

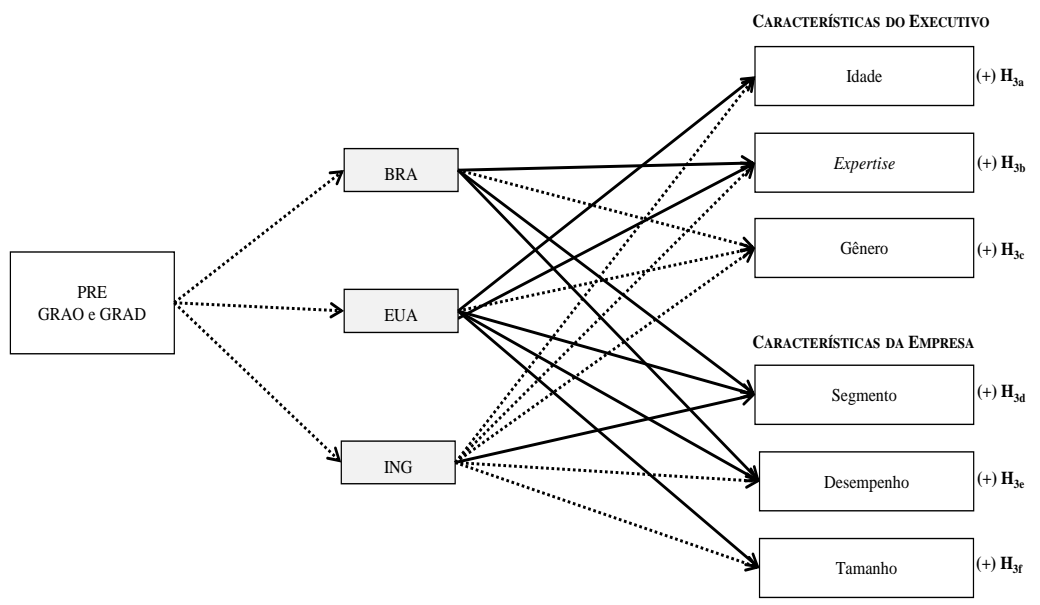

Figura 19 - Hipóteses confirmadas no Grupo III

Fonte: Elaboração própria.

Na Figura 19 evidencia-se que dentre as hipóteses elaboradas, considerados os sinais, a $\mathrm{H}_{3 a}$, se confirmou para as empresas industriais 
estadunidenses, a $\mathrm{H}_{3 \mathrm{~b}}$ para as brasileiras, a $\mathrm{H}_{3 \mathrm{~d}}$ para os três países, a $\mathrm{H}_{3 \mathrm{e}}$ para o Brasil e Estados Unidos, e a $\mathrm{H}_{3 \mathrm{f}}$ para as indústrias estadunidenses, analisadas. Os testes efetuados para verificação das hipóteses do Grupo III estão descritos a seguir.

Para verificação das hipóteses descritas a seguir foi utilizada a técnica de estatística multivariada de correlação canônica. As primeiras três hipóteses do grupo III são relativas às características do executivo.

$\mathrm{Na}$ primeira hipótese do grupo III, $\mathrm{H}_{3 \mathrm{a}}$ de que a relação da política de remuneração do executivo com o nível de gerenciamento de resultados se modifica se a amostra for estratificada pela variável endógena idade do executivo, a análise de correlação canônica apresentou os coeficientes positivos para os três países. Demonstra que, quanto maior a idade do executivo maior a relação entre a política de remuneração deste e o nível de gerenciamento de resultados, principalmente para as empresas industriais brasileiras e estadunidenses, que obtiveram significância estatística nos testes. Nestas se rejeitou a hipótese nula, aceitando a hipótese alternativa. Subentende-se que o contrário também é verdadeiro, quanto menor a idade, menor a relação identificada. A modificação pode ser verificada diante da comparação entre a correlação e o p-value antes e após a segregação da amostra em extratos de idade.

Assim como na pesquisa de Farrel e Whidbee (2003), em que a idade do executivo foi relevante na rotatividade do CEO, nesta pesquisa a idade revelou influência, pois modificou a relação entre a remuneração do executivo e o nível de gerenciamento de resultados por atividades operacionais e por accruals discricionárias.

$\mathrm{Na}$ segunda hipótese do grupo $\mathrm{III}, \mathrm{H}_{3 \mathrm{~b}}$, de que a relação da política de remuneração do executivo com o nível de gerenciamento de resultados se modifica se a amostra for estratificada pela variável endógena expertise do executivo, a análise de correlação canônica demonstrou que para as empresas industriais inglesas não houve significância estatística na correlação calculada, tornando o resultado inconclusivo para estas. Assim não foi possível rejeitar a hipótese nula. Para as empresas industriais brasileiras e estadunidenses houve significância na correlação calculada ao nível de confiança de $95 \%$, portanto, para estas se rejeita a hipótese nula e se aceita a hipótese alternativa. A modificação pode ser verificada na comparação entre a correlação e o p-value antes e após a segregação da amostra em extratos de expertise.

Em síntese, os coeficientes positivos e crescentes permitem inferir que quanto mais expertise o executivo possuir, maior a relação entre a política de remuneração deste e o nível de gerenciamento de 
resultados. Os resultados dos testes das empresas brasileiras e estadunidenses permitem confirmar esta hipótese.

Conforme os achados de Aier et al. (2005), de que a expertise do CEO é uma variável relevante no estudo das ações organizacionais, nesta pesquisa também se confirma que esta variável é proeminente no estudo da relação entre a política de remuneração e o nível de gerenciamento de resultados.

A terceira hipótese do grupo $\mathrm{III}, \mathrm{H}_{3 c}$, de que a relação da política de remuneração do executivo com o nível de gerenciamento de resultados se modifica se a amostra for estratificada pela variável endógena gênero do executivo, não foi testada, pois os executivos são predominantemente do gênero masculino nas empresas da amostra pesquisada. Desta forma, o gênero do executivo que, conforme Barua et al. (2010) e Peni e Vähämaa (2010), implicam nas accruals discricionárias e na gestão das atividades operacionais, não pôde ser testado quanto à relação da política de remuneração dos executivos e o nível de gerenciamento de resultados, devido à baixa representatividade dos executivos do gênero feminino na amostra analisada.

As próximas três hipóteses referem-se às características da empresa. Na quarta hipótese do grupo III, $\mathrm{H}_{3 \mathrm{~d}}$, de que a relação da política de remuneração do executivo com o nível de gerenciamento de resultados se modifica se a amostra for estratificada pela variável endógena segmento de atuação da empresa, a análise de correlação canônica demonstrou que os coeficientes foram positivos e crescentes para os três países. Isso demonstra que, quanto maior a homogeneidade da empresa maior a relação entre a política de remuneração do executivo e o nível de gerenciamento de resultados. As empresas industriais dos três países obtiveram significância estatística nos testes. Assim, se rejeitou a hipótese nula aceitando a hipótese alternativa, para o segmento têxtil nas indústrias brasileiras; para os segmentos de minerais não metálicos e outros bens para as estadunidenses; e para os segmentos de siderurgia e metalurgia e equipamentos de transporte para as indústrias inglesas.

A modificação pode ser verificada na comparação entre a correlação e o p-value antes e após a segregação da amostra em extratos de homogeneidade. Subentende-se que o contrário também é verdadeiro, quanto menos homogêneo for o grupo de empresas menor sua a relação com a política de remuneração dos executivos e o nível de gerenciamento de resultados.

Conforme os resultados da pesquisa de Baber, Kang e Kumar (1998), de que a homogeneidade da empresa é associada à persistência 
de lucros, e de Farrel e Whidbee (2003), de que é associada à rotatividade do CEO, por meio desta pesquisa é possível acrescer que a homogeneidade da indústria é associada à relação da política de remuneração dos executivos com o nível de gerenciamento de resultados.

$\mathrm{Na}$ quinta hipótese do grupo III, $\mathrm{H}_{3 \mathrm{e}}$, de que a relação da política de remuneração do executivo com o nível de gerenciamento de resultados se modifica se a amostra for estratificada pela variável endógena desempenho da empresa, a análise de correlação canônica demonstrou que para as empresas industriais inglesas não houve significância estatística na correlação calculada, não permitindo a rejeição da hipótese nula, mantendo o resultado inconclusivo para estas empresas da amostra. Por outro lado, os resultados para as empresas industriais brasileiras e estadunidenses da amostra permitem rejeitar a hipótese nula e aceitar a alternativa, de que a relação da política de remuneração do executivo com o nível de gerenciamento de resultados se modifica se a amostra for estratificada pela variável endógena desempenho da empresa. A modificação pode ser verificada na comparação entre a correlação e o p-value antes e após a segregação da amostra em extratos de desempenho. Os coeficientes positivos para os três países indicam que quanto mais lucro a empresa possuir maior será a relação da política de remuneração com o nível de gerenciamento de resultados. O contrário também é verdadeiro.

Acrescenta-se, por meio dos resultados desta pesquisa, aos achados de Murphy (1999), que o desempenho da empresa além de ser associado ao plano de remuneração do executivo, também é associado ao nível de gerenciamento de resultados por atividades operacionais e accruals discricionárias.

$\mathrm{Na}$ última hipótese do grupo III, $\mathrm{H}_{3 \mathrm{f}}$, de que a relação da política de remuneração do executivo com o nível de gerenciamento de resultados se modifica se a amostra for estratificada pela variável endógena tamanho da empresa, a análise de correlação canônica demonstrou que os coeficientes positivos indicam uma relação positiva. Portanto, permite confirmar que quanto maior o tamanho da empresa, maior a relação da política de remuneração do executivo com o nível de gerenciamento de resultados.

A modificação pode ser verificada diante da comparação entre a correlação e o p-value antes e após a segregação da amostra em extratos de tamanho. No entanto, para as empresas industriais brasileiras e inglesas não foi possível rejeitar estatisticamente a hipótese nula. Ainda assim, as empresas industriais estadunidenses da amostra obtiveram um 
p-value válido, ao nível de confiança de 95\%, para rejeitar a hipótese nula e aceitar a hipótese alternativa.

Por fim, a última característica da empresa testada nesta pesquisa, tamanho da empresa, permite corroborar os achados de Jensen e Murphy (1990), de que o tamanho da empresa está associado ao nível de remuneração do executivo, acrescendo que também está associado à estrutura da remuneração do mesmo.

Ao término da efetivação dos testes relativos à segregação da amostra das empresas industriais brasileiras, estadunidenses e inglesas, pelos critérios definidos nas variáveis endógenas, foi possível observar que duas características do executivo (idade e expertise) e três características da empresa (segmento, desempenho e tamanho) foram relevantes no estudo da relação entre a política de remuneração dos executivos e o nível de gerenciamento de resultados, no contexto desta pesquisa. 


\section{CONCLUSÕES E RECOMENDAÇÕES}

Este capítulo apresenta as conclusões do estudo realizado e recomendações para futuras pesquisas sobre o tema investigado.

\subsection{CONCLUSÕES}

Este estudo objetivou identificar a influência da política de remuneração de executivos no nível de gerenciamento de resultados sob a ótica das escolhas contábeis, por meio de atividades operacionais e accruals discricionárias, em empresas industriais brasileiras, estadunidenses e inglesas. Uma pesquisa descritiva com abordagem quantitativa foi realizada por meio de análise documental com base nos dados coletados na CVM para os executivos brasileiros, na SEC para os estadunidenses e nas demonstrações contábeis para as empresas inglesas. Os dados contábeis foram coletados na base de dados da Economática para as empresas industriais brasileiras e na base de dados da Thomson One Banker para as empresas industriais estadunidenses e inglesas.

Reportando-se ao primeiro objetivo específico desta pesquisa, o de identificar a política de remuneração dos executivos nas perspectivas de nível e estrutura, conforme a proposição de Murphy (1999), de empresas industriais brasileiras, estadunidenses e inglesas, no período de 2007 a 2010, pode-se descrever algumas considerações.

Por falta de padronização nas informações sobre a remuneração dos executivos para as empresas industriais inglesas, as denominações utilizadas dificultaram, mas não inviabilizaram a pesquisa. Nas empresas do Brasil e dos Estados Unidos da América a operacionalização da pesquisa foi facilitada pela padronização exigida, respectivamente, pela CVM, no Formulário de Referência, e pela SEC, no Formulário DEF 14A, $10 \mathrm{~K}$ e 20F. As empresas inglesas não evidenciam em seus annual reports características detalhadas de seus executivos, como a formação e a experiência profissional, descreveram apenas sucintamente o tempo de trabalho na empresa.

No que concerne às características da política de remuneração dos três países, constatou-se na pesquisa realizada que a estrutura da diretoria executiva é similar nos três países. Houve semelhança no comportamento do nível de remuneração dos três países, com crescimento percentual no salário e na remuneração total dos executivos, confirmando-se, assim, uma ascensão do nível de remuneração. 
Mesmo considerando diferenças cambiais, a remuneração dos executivos estadunidenses é muito superior ao dos brasileiros e ingleses. Esta supremacia do nível de remuneração dos executivos estadunidenses em relação aos demais países pode estar atrelado ao estágio de desenvolvimento econômico e/ou tecnológico em que os Estados Unidos da América se encontram, que é diferente do estágio em que o Brasil e a Inglaterra estão.

A política de remuneração dos executivos brasileiros e ingleses é similar, quanto à sua estrutura, pois ambos não costumam remunerar seus executivos por meio de ações, inversamente aos estadunidenses que possuem a maior parte da estrutura de sua remuneração em ações. Infere-se da pesquisa realizada que para os executivos estadunidenses a remuneração é fortemente atrelada ao desempenho acionário das empresas a que estão vinculados, este vínculo pode proceder do fato de nos Estados Unidos da América o conceito de remuneração baseada em ações ser mais difundido que nos demais países analisados.

Os resultados desta pesquisa corroboram os achados da pesquisa de Murphy (1999), quanto à remuneração dos executivos de empresas estadunidenses, que se mantém em primeiro lugar frente a outros países. Também na estrutura da remuneração destes, pois o percentual da remuneração em ações apresenta-se elevado em relação à remuneração total. Mesmo que nesta pesquisa tenham sido avaliadas apenas as remunerações de executivos de empresas industriais, os resultados são semelhantes ao estudo de Murphy (1999).

No que diz respeito so segundo objetivo específico desta pesquisa, o de estimar o nível normal de gerenciamento de resultados a partir das atividades operacionais das empresas pesquisadas, no período de 2007 a 2010, considerando as despesas com vendas, gerais e administrativas pelo modelo de Anderson, Banker e Janakiraman (2003); as despesas com Pesquisa e Desenvolvimento (P\&D) pelo modelo de Gunny (2005); e o nível de produção pelo modelo de Roychowdhury (2005), pode-se elencar algumas considerações.

Com relação aos inputs do modelo de gerenciamento de resultados por meio de atividades operacionais, despesas com vendas gerais e administrativas, foi possível constatar que as vendas das empresas estadunidenses e inglesas tiveram queda, enquanto que no Brasil o faturamento se manteve crescente em todo o período. Este reflexo pode estar relacionado à crise Subprime que se originou nos Estados Unidos e em seguida se refletiu nos demais países em razão de suas parcerias comerciais. 
Quanto ao nível de gerenciamento de resultados, por meio de atividades operacionais, despesas com vendas, gerais e administrativas, nas empresas industriais brasileiras, estadunidenses e inglesas no período analisado, a pesquisa revelou que o maior valor médio de gerenciamento ocorreu nas empresas industriais inglesas, no período de 2007 a 2010, em segundo lugar nas empresas estadunidenses e por último nas brasileiras.

Com relação ao gerenciamento de resultados por meio de atividades operacionais, especificamente de despesas com pesquisa e desenvolvimento, este não foi possível estimar para a amostra pesquisada, pois ao coletar as subvariáveis do modelo de Gunny (2005) a redução da amostra excluiu as empresas industriais brasileiras. Assim, inviabilizou o alcance do objetivo específico proposto neste estudo, relativo às empresas brasileiras, estadunidenses e inglesas.

Quanto ao nível de gerenciamento de resultados, por meio de atividades operacionais, nível de produção e aumento temporário das vendas por meio de descontos anormais nas empresas industriais brasileiras, estadunidenses e inglesas no período analisado, constatou-se que o maior valor médio de gerenciamento ocorreu nas empresas industriais inglesas no período de 2007 a 2010, em segundo lugar nas empresas estadunidenses e, por último, nas brasileiras.

Nesta pesquisa confirmaram-se os resultados da pesquisa de Anderson, Banker e Janakiramam (2003), com relação ao gerenciamento de resultados por atividades operacionais, despesas com vendas, gerais e administrativas e nível de produção, de que os gestores deliberadamente ajustam os recursos comprometidos com as atividades, também que os custos variam de acordo com as circunstâncias e não pela atividade. Também corroboram os achados de Gunny (2005), de que as empresas investem de forma míope em despesas com vendas, gerais e administrativas para aumentar as receitas e que reduzem os preços para impulsionar as vendas no período corrente e reduzir custos de produção. A prática de smoothing citada por Roychowdhury (2005) também se refletiu nos resultados desta pesquisa para as empresas do setor industrial.

Possíveis motivos para que o gerenciamento de resultados por manipulação de despesas com vendas, gerais e administrativas e níveis de produção seja maior na Inglaterra do que nos Estados Unidos e Brasil podem estar direcionados às diferenças internacionais das normas contábeis dos três países. $\mathrm{O}$ fato da Inglaterra ter implantado o International Financial Reporting Standars - IFRS em suas demonstrações financeiras consolidadas em 2005, os Estados Unidos em 
2007 e o Brasil em 2010 pode estar vinculado aos resultados encontrados.

Sobre o terceiro objetivo específico desta pesquisa, o de estimar o nível normal de gerenciamento de resultados das empresas pesquisadas, no período de 2007 a 2010, a partir das accruals discricionárias pelo modelo de Dechow, Sloan e Sweeney (1995), podem-se tecer algumas considerações.

Constatou-se pela pesquisa que o maior valor de gerenciamento de resultados por accruals discricionárias foi das empresas brasileiras, em segundo lugar para as inglesas e por último para as estadunidenses. Assim como na pesquisa de Cardoso e Martinez (2006), os resultados indicam que as empresas gerenciam os números contábeis mediante decisões operacionais e escolhas contábeis.

O Índice de Gini adaptado se revelou uma metodologia diferenciada para análise das accruals discricionárias, pois considera o maior gerenciamento com inputs de valores modulados, independentemente do sinal positivo ou negativo. Por esta metodologia as empresas industriais inglesas tiveram maior gerenciamento de resultados por accruals discricionárias, seguidas pelas estadunidenses e, por último, as brasileiras.

No que concerne ao quarto objetivo específico desta pesquisa, as influências da política de remuneração dos executivos no nível de gerenciamento de resultados sob a ótica das escolhas contábeis por meio de atividades operacionais e accruals discricionárias em empresas industriais brasileiras, estadunidenses e inglesas, identificadas nesta pesquisa, passam a ser comentadas a seguir com base nas hipóteses testadas e à luz de pesquisas anteriores.

A pesquisa revelou, conforme a influência ou associação entre a política de remuneração dos executivos e o nível de gerenciamento de resultados, mensurada por meio da análise dos coeficientes de correlação canônica, maior associação para as empresas do Brasil, em segundo lugar para as empresas dos Estados Unidos e em terceiro lugar da Inglaterra. A influência recíproca entre o conjunto se revelou positiva, ou seja, aumentos no conjunto 1 (que integra percentual de salário, percentual de bônus, percentual de remuneração em ações e percentual de outras remunerações) se refletem em aumentos no conjunto 2 (que integra o gerenciamento de resultados por atividades operacionais, despesas com vendas, gerais e administrativas; o gerenciamento de resultados por atividades operacionais, nível de produção; e o gerenciamento de resultados por accruals discricionárias). 
A constatação de Murphy (1999), de que os Estados Unidos da América é o país que possui o maior nível de remuneração em dinheiro e total foi confirmada pelos resultados desta pesquisa. Entretanto, esperava-se que por esse motivo este país deveria possuir o maior nível de gerenciamento de resultados, por meio de atividades operacionais e accruals discricionárias, fato que não foi constatado no estudo realizado.

As hipóteses de pesquisa do grupo I (que integram a política de remuneração dos executivos com o gerenciamento de resultados por atividades operacionais e accruals discricionárias) e do grupo II (que integram a remuneração em dinheiro contida na política de remuneração dos executivos com o gerenciamento de resultados por atividades operacionais e accruals discricionárias, atreladas a esse resultado) são descritas sinteticamente a seguir.

A hipótese $\mathrm{H}_{1}$, de que há relação entre a política de remuneração do executivo e o nível de gerenciamento de resultados foi estatisticamente confirmada. Conforme o resultado esperado do teste, a pesquisa revelou que há relação entre a política de remuneração do executivo, em termos percentuais, e o gerenciamento de resultados, por meio de atividades operacionais e por accruals discricionárias para as empresas industriais brasileiras e estadunidenses. Para as inglesas houve correlação, mas não significativa estatisticamente.

O resultado desta pesquisa, de que a política de remuneração do executivo influencia o nível de gerenciamento de resultados, coaduna com os achados das pesquisas de Healy (1985), DeAngelo (1986), Schipper (1989), Jensen (1993), Guidry, Leone e Rock (1999), Cheng e Warfield (2005) e Bergstressera e Philippon (2006), de que os incentivos, com base no plano de remuneração dos executivos, incentiva a prática de escolhas contábeis. E isso se reflete em gerenciamento de resultados, confirmando as premissas de Zang (2005) e Cardoso e Martinez (2006), de que o gerenciamento de resultados, por meio de atividades operacionais e accruals, é positivamente correlacionado com os incentivos para sua realização.

Para as demais hipóteses definidas no Grupo I, que se referem à política de remuneração dos executivos com o gerenciamento de resultados por atividades operacionais e accruals discricionárias, descrevem-se conjuntamente os resultados da pesquisa:

$\mathrm{H}_{1 \mathrm{a}}$ - foi inconclusiva no estudo se há relação positiva entre a política de remuneração do executivo e o nível de gerenciamento de resultados por meio de atividades 
operacionais, especificamente despesas com vendas e despesas gerais e administrativas;

$\mathrm{H}_{1 \mathrm{~b}}$ - não foi possível testar a hipótese devido à falta de informações contábeis disponíveis para esta amostra, se há relação positiva entre a política de remuneração do executivo e o nível de gerenciamento de resultados por meio de atividades operacionais, especificamente despesas com pesquisa e desenvolvimento;

$\mathrm{H}_{1 \mathrm{c}}$ - foi confirmada a hipótese para as empresas industriais brasileiras que há relação positiva entre a política de remuneração do executivo e o nível de gerenciamento de resultados por meio de atividades operacionais, especificamente pelo nível de produção da empresa;

$\mathrm{H}_{1 \mathrm{~d}}$ - foi confirmada a hipótese para as empresas industriais estadunidenses que há relação positiva entre a política de remuneração do executivo e o nível de gerenciamento de resultados por accruals discricionárias.

Os resultados desta pesquisa corroboram com os achados de Anderson, Banker e Janakiramam (2003), de que as atividades operacionais (despesas com vendas, gerais e administrativas) variam de acordo com as circunstâncias e não pela atividade. Também com as consequências da manipulação de atividades operacionais (nível de produção) destacadas por Gunny (2005) e Gupta, Pevzner e Seethamraju (2005), de que o manejo nos resultados contábeis tem implicações nas decisões de absorção de custos de produção.

Esta pesquisa agrega ao corpo teórico existente sobre o gerenciamento de resultados que o nível de produção das empresas industriais influencia a política de remuneração dos executivos isoladamente e que as despesas com vendas, gerais e administrativas também exerce influência, mas não de forma isolada, e, sim, conjuntamente com outras modalidades de gerenciamento de resultados.

Os resultados sintéticos das hipóteses do grupo II, que se referem à remuneração em dinheiro contida na política de remuneração dos executivos com o gerenciamento de resultados por atividades operacionais e accruals discricionárias, são exibidos a seguir:

$\mathrm{H}_{2 \mathrm{a}}$ - foi inconclusiva a hipótese de que países que possuem a maior remuneração em dinheiro contida na política de remuneração dos executivos possuem maior nível de gerenciamento de resultados por meio de atividades 
operacionais, especificamente despesas com vendas e despesas gerais e administrativas;

$\mathrm{H}_{2 b}$ - não foi possível testar a hipótese no estudo, devido à falta de informações contábeis disponíveis na amostra analisada, se países que possuem a maior remuneração em dinheiro contida na política de remuneração dos executivos possuem maior nível de gerenciamento de resultados por meio de atividades operacionais, especificamente despesas com pesquisa e desenvolvimento;

$\mathrm{H}_{2 \mathrm{c}}$ - foi válida para os testes nas empresas industriais brasileiras a hipótese de que países que possuem a maior remuneração em dinheiro contida na política de remuneração dos executivos possuem maior nível de gerenciamento de resultados por meio de atividades operacionais, especificamente pelo nível de produção da empresa;

$\mathrm{H}_{2 \mathrm{~d}}$ - foi inconclusiva no estudo realizado a hipótese de que países que possuem a maior remuneração em dinheiro contida na política de remuneração dos executivos possuem maior nível de gerenciamento de resultados por accruals discricionárias.

Os resultados da pesquisa indicaram associação positiva entre a remuneração em dinheiro contida na política de remuneração do executivo e o nível de gerenciamento de resultados por atividades operacionais, níveis de produção. Fato que permite corroborar os resultados da pesquisa de Gaver e Gaver (1998) e Comprix e Muller (2006), de que o gerenciamento de resultados possui relação com a remuneração em dinheiro do executivo.

Para as hipóteses definidas no Grupo III, que se referem à política de remuneração dos executivos com o gerenciamento de resultados por atividades operacionais e accruals discricionárias com as variáveis endógenas, características do executivo, idade, expertise e gênero; e as características da empresa, segmento, desempenho e porte, descrevem-se conjuntamente os resultados da pesquisa:

$\mathrm{H}_{3 a}$ - foi confirmada a hipótese de que a relação da política de remuneração do executivo com o nível de gerenciamento de resultados se modifica se a amostra for estratificada pela variável endógena idade do executivo; $\mathrm{H}_{3 \mathrm{~b}}$ - foi confirmada a hipótese de que a relação da política de remuneração do executivo com o nível de gerenciamento de resultados se modifica se a amostra for estratificada pela variável endógena expertise do executivo; 
$\mathrm{H}_{3 c}$ - não foi possível testar a hipótese de que a relação da política de remuneração do executivo com o nível de gerenciamento de resultados se modifica se a amostra for estratificada pela variável endógena gênero do executivo, para esta amostra;

$\mathrm{H}_{3 \mathrm{~d}}$ - foi confirmada a hipótese de que a relação da política de remuneração do executivo com o nível de gerenciamento de resultados se modifica se a amostra for estratificada pela variável endógena segmento de atuação da empresa;

$\mathrm{H}_{3 \mathrm{e}}$ - foi confirmada a hipótese de que a relação da política de remuneração do executivo com o nível de gerenciamento de resultados se modifica se a amostra for estratificada pela variável endógena desempenho da empresa;

$\mathrm{H}_{3 \mathrm{f}}$ - foi confirmada a hipótese de que a relação da política de remuneração do executivo com o nível de gerenciamento de resultados se modifica se a amostra for estratificada pela variável endógena tamanho da empresa.

No que tange ao quinto objetivo específico desta pesquisa, o de analisar a relação da política de remuneração dos executivos e do nível de gerenciamento de resultados, com as características de idade, expertise e gênero dos executivos e das características de homogeneidade, desempenho e tamanho das empresas, a seguir descreve-se a síntese da análise.

As variáveis endógenas, que motivaram a segregação da amostra em extratos, demonstraram que a política de remuneração dos executivos e o nível de gerenciamento de resultados, por meio de atividades operacionais, despesas com vendas, gerais e administrativas e nível de produção e por meio de accruals discricionárias, se modifica, tanto na quantidade de associação, quanto na significância estatística: a) para as características do executivo: idade e expertise para o Brasil e Estados Unidos; b) para as características da empresa: segmento para os três países, desempenho e tamanho para o Brasil e Estados Unidos.

Os resultados obtidos nesta pesquisa, com a segregação da amostra por variáveis endógenas, corroboram com os achados de Jensen e Murphy (1990), Baber, Kang e Kumar (1998), Murphy (1999), Farrel e Whidbee (2003), Aier et al. (2005) e Mek, Rao e Skousen (2007), de que as características dos executivos idade e expertise e as características da empresa segmento, desempenho e tamanho são relevantes em estudos de remuneração de executivos e gerenciamento de resultados. 
A tese de que a política de remuneração dos executivos influencia o nível de gerenciamento de resultados, por meio de atividades operacionais ou por accruals discricionárias, foi confirmada para as empresas industriais brasileiras e estadunidenses. Portanto, parcialmente confirmada, pois para as empresas industriais inglesas não houve validação dos testes estatísticos realizados, embora tenha havido associação. Reforça-se assim a originalidade e observa-se a contribuição do estudo ao pesquisar empiricamente as atividades operacionais de despesas com vendas, gerais e administrativas e nível de produção e accruals discricionárias, concomitantemente, em empresas industriais brasileiras, estadunidenses e inglesas.

Conclui-se que há influência positiva da política de remuneração dos executivos no nível de gerenciamento de resultados sob a ótica das escolhas contábeis, por meio de atividades operacionais e accruals discricionárias, nas empresas industriais brasileiras, estadunidenses e inglesas pesquisadas, para o período de 2007 a 2010.

Com relação a política de remuneração dos executivos, os Estados Unidos são fortemente influenciados pela remuneração baseada em ações, dado que o seu mercado acionário é desenvolvido e a dipersão da propriedade é um fato normal na economia do país. Para os executivos ingleses, assim como para os brasileiros a remuneração baseada em ações é inexpressiva, devido a característica cultural de concentração da propriedade destes países, que trava o desenvolvimento do mercado de capitais.

Com relação ao gerenciamento de resultados, realizado pelos agentes organizacionais, este não é, necessariamente, um procedimento nefasto ou indesejável, pois tomar decisões operacionais é obrigação dos agentes organizacionais no intuito de alcançar metas. Ainda, os modelos existentes para mensuração de gerenciamento de resultados realizam um processo inverso à ação organizacional, ou seja, depois de realizadas as ações, os modelos buscam captar os efeitos destas, por meio de reflexos nos números contábeis. Esse procedimento contribui para a redução de assimetria informacional ou mesmo para aumentar a transparência das ações organizacionais.

Os resultados da pesquisa adicionam ao corpo teórico e aos achados de pesquisas anteriores, que (i) o plano de remuneração do executivo o incentiva à prática de gerenciamento de resultados, (ii) o executivo manipula os resultados contábeis, (iii) o executivo além de escolhas contábeis também faz escolhas por atividades operacionais para efetivar o gerenciamento de resultados. 
Fortalece-se assim o exposto pela Teoria da Agência conforme Jensen e Meckling (1976), de que a remuneração do executivo, que se constitui em mecanismo de vinculação entre o principal e o agente, motiva o agente, que possui uma lente oportunista, nos moldes do exposto por Williamson (1985) e Eisenhardt (1989), à prática do gerenciamento de resultados. A remuneração, para o agente, se constitui em fonte de recursos, tanto em nível como em estrutura, e ao ser avaliado para a efetivação desta, procura otimizar suas bases avaliativas, gerando assim escolhas contábeis e escolhas de ações organizacionais que maximizem a sua renda.

O distanciamento contábil entre a academia, principalmente no contexto das pesquisas sobre a contabilidade positiva, e a prática organizacional se reduz na medida em que pesquisas empíricas com informações contábeis e práticas organizacionais são realizadas, como é o caso do gerenciamento de resultados. Pesquisas dessa natureza contribuem para demonstrar a transparência das ações realizadas, que são relevantes tanto para os usuários internos como para os externos da contabilidade das empresas.

No âmbito acadêmico, a Teoria Contábil necessita de aporte empírico para que possa ter suas hipóteses comprovadas sob diversas lentes, de forma a estruturar um corpo de conhecimento estruturado e organizado. A Contabilidade como ciência não diverge das demais áreas científicas, em que o escopo científico se amplia a cada novo momento. O ensino da Ciência Contábil necessita de fomento atualizado de pesquisas empíricas que demonstrem as novas possibilidades da profissão e do mundo da pesquisa.

\subsection{RECOMENDAÇÕES}

Considerando-se as limitações deste estudo, recomenda-se para pesquisas futuras a verificação do nível de gerenciamento de resultados por meio de atividades operacionais, despesas com vendas, gerais e administrativas em outros setores da economia, como no comércio e serviços e a influência deste na política de remuneração de seus executivos.

Também, seguindo as instruções de Dechow et al. (2011) recomenda-se incorporar em pesquisas futuras reversões de accruals no intento de mitigar os problemas de especificação dos modelos de mensuração do gerenciamento de resultados.

Recomenda-se verificar também se o controle acionário, a qualidade e honorários de auditoria interna e externa e a qualidade da 
governança da empresa, afetam a relação da política de remuneração do executivo com o nível de gerenciamento de resultados por meio de atividades operacionais e por accruals discricionárias em empresas industriais, comerciais e de serviços.

Outra possibilidade de pesquisa relativa ao tema é a de optar por países diferentes dos considerados neste estudo, ou, ainda com os mesmos, mas utilizando variáveis que controlem os efeitos de diferenças culturais, trabalhistas e econômicas dos países, pois estas podem afetar as demonstrações financeiras que impactam em distintas escolhas contábeis e planos de remuneração.

Sugere-se ainda a investigação dos reflexos da implementação das International Financial Reporting Standards (IFRS) nas escolhas contábeis e sua relação com a remuneração de executivos. É possível que os critérios contábeis adotados pelos diversos países em momentos diferentes impactem a relação da remuneração do executivo com o gerenciamento de resultados. 


\section{REFERÊNCIAS}

ABOODY, D.; KASZNIK, R. CEO stock option awards and the timing of corporate voluntary disclosures. Journal of Accounting and Economics, v. 29, p. 73-100, 2000.

AHMED, A. S.; TAKEDA, C.; THOMAS, S. Bank loan loss provisions: a reexamination of capital management, earnings management and signaling effect. Journal of Accounting and Economics, v. 28, p.1-25, 1999.

AIER, J. K.; COMPRIX, J.; GUNLOCK, M. T.; LEE, D. The financial expertise of CFOs and accounting restatements. Accounting Horizons, v. 19, n. 3, p. 123-135, Sep. 2005.

ALCHIAN, A.; DEMSETZ, H. Production, information costs, and economic organization. The American Economic Review. v. 62, n. 5, Dec. 1972.

ANDERSON, M., BANKER, R.D.; JANAKIRAMAN, S.N. Are selling, general, and administrative costs 'sticky'? Journal of Accounting Research, v. 41, n. 1, p. 47-63, 2003.

ANTHONY, R.N.; GOVINDARAJAN, V. Sistemas de controle gerencial. São Paulo: Atlas, 2002.

APPOLINÁRIO, F. Metodologia da ciência: filosofia e prática da pesquisa. São Paulo: Pioneira Thomson Learning, 2006.

ARMSTRONG, P. Contradiction and social dynamics in the capitalist agency relationship, Accounting, Organizations and Society, v. 16, n. 1, p. 1-25, 1991.

ARROW, K.J. The economics of agency. In: PRATT, J.W.; ZECKHAUSER, R.J. (Eds.). Principals and agents: the structure of American business. Boston: Harvard Business Scholl Press, 1985.

BABER, W.R.; JANAKIRAMAN, S.N.; KANG, S-H. Investment opportunities and the structure of executive compensation. Journal of Accounting and Economics, v. 21, p. 297-318, 1996. 
BABER, W.R.; KANG, S-H; KUMAR, K.R. Accounting earnings and executive compensation: the role of earnings persistence. Journal of Accounting and Economics, v. 25, p. 169 -193, 1998.

BABER, W.R.; KANG, S-H; KUMAR, K.R. The explanatory power of earnings levels vs. Earnings changes in the context of executive compensation. The Accounting Review, v. 74, n. 4, p. 459-472, 1999.

BALL, R.; SHIVAKUMAR, L. Earnings quality in U.K. private firms: comparative loss recognition timeliness. Journal of Accounting and Economics, vol. 39, n. 1, p. 83-128, 2005.

BAPTISTA, E.M.B. Análise do perfil das empresas brasileiras segundo o nível de gerenciamento de resultados. 2008. $303 \mathrm{f}$. Tese (Doutorado em Administração) - Escola de Administração, Universidade Federal do Rio Grande do Sul, Porto Alegre.

BARNARD, C.I. The Functions of the Executive, Cambridge, MA: Harvard University Press, 1938.

BARNEY, J.B.; HESTERLY, W. Economia das organizações: entendendo a relação entre as organizações e a análise econômica. In: CLEGG, C.; HARD, C.; NORD, W.R. (Orgs.) Handbook de estudos organizacionais: ação e análise organizacionais, v. 3. São Paulo: Atlas, 2004.

BARNEY, J.B.; OUCHI, W.G. Organizational economics: toward a new paradigm for understanding and studying organizations. San Francisco: Jossey-Bass, 1986.

BARTOV, E.; MOHANRAM, P. Private information, earnings manipulations, and executive stock-option exercises. The Accounting Review, v. 79, n. 4, p. 889-920, 2004.

BARUA, A.; DAVIDSON, L.F.; RAMA, D.V.; THIRUVADI, S. CFO gender and accruals quality. Accounting Horizons, v. 24, n. 1, p. 25-39, 2010.

BASIRUDDIN, R. The relationship between governance practices, audit quality and earnings management: UK evidence. 2011. $303 \mathrm{f}$. 
Doctoral thesis. (Degree of Doctor of Philosophy) Durham University, United Kingdom.

BENS, D.A.; NAGAR, V.; SKINNER, D.J.; WONG, M.H.F. Employee stock options, EPS dilution, and stock repurchases. Journal of Accounting and Economics, v. 36, p. 51-90, 2003.

BERGSTRESSERA, D.; PHILIPPON, T. CEO incentives and earnings management. Journal of Financial Economics, v. 80, p. 511-529, 2006.

BERLE, A.A.; MEANS, G.C. The Modern Corporation and Private Property, New York, Macmillan, 1932. (reprinted 1968).

BROOKMAN, J.T.; JANDIK, T.; RENNIE, C. G. A Comparison of CEO Compensation Data Sources. Working paper, University of Arkansas, 2006.

BRUYNE, P.; HERMAN, J.; SCHOUTHEETE, M. Dinâmica da pesquisa em ciências sociais. Rio de Janeiro: F. Alves, 1977.

BURGSTAHLER, D.; DICHEV, I. Earnings management to avoid earnings decreases and losses. Journal of Accounting and Economics, v. 24, p. 99-126, 1997.

BURRELL, G. Ciência normal, paradigmas, metáforas discursos e genealogia da análise. In: CLEGG, S.R.; HARDY, C.; NORD, W.R. (Orgs.) Handbook de estudos organizacionais. São Paulo: Atlas, 1998.

BURRELL, G.; MORGAN, G. Sociological Paradigms and Organizational Analysis. London: Heinemann, 1979.

CADBURY COMITTEE. Report of the commitee on the financial aspects of corporate governance. London: Gee, 1992.

CALDAS, M.P. Paradigmas em estudos organizacionais: uma introdução à série. In: CALDAS, M.P.; BERTERO, C.O. (coords.) Teoria das Organizações. São Paulo: Atlas, 2007.

CALDAS, M.P.; CUNHA, M.P. Ecologistas e economistas organizacionais: o paradigma funcionalista em expansão no final do 
século XX. In: CALDAS, M.P.; BERTERO, C.O. (coords.) Teoria das Organizações. São Paulo: Atlas, 2007.

CARDOSO, R.L. Regulação econômica e escolhas de práticas contábeis: evidências do mercado se saúde suplementar brasileiro. 2005. 154f. Tese (Doutorado em Ciências Contábeis). FEA/USP. Faculdade de Economia e Administração e Contabilidade, Universidade de São Paulo, São Paulo.

CARDOSO, R.L.; MARTINEZ, A.L. Gerenciamento de Resultados Contábeis no Brasil mediante Decisões Operacionais. In: Encontro Nacional dos Programas de Pós-graduação em Administração, XXX, 2006, Salvador. Anais... Salvador: ANPAD, 2006. CD-ROM.

CARTER, M.E.; LYNCH, L.J.; ZECHMAN, S.L.C. Changes in bonus contracts in the post-Sarbanes-Oxley era. Review of Accounting Studies, v. 14, p. 480-506, 2009.

CENTRAL INTELLIGENCE AGENCY UNITED STATES OF AMERICA. The world factbook. 2010. Disponível em: <https://www.cia.gov/library/publications/the-world-factbook> Acesso em: 24 fev. 2012.

CERVO, A.L.; BERVIAN, P.A. Metodologia científica. 5. ed. São Paulo: Prentice Hall, 2002.

CHEN, C-Y. Investment opportunities and the relation between equity value and employees' bonus. Journal of business Finance \& Accounting. Oxford, v. 30, n. 7/8, p. 941-973, Sep./Oct. 2003.

CHENG, Q.; WARFIELD, T.D. Equity incentives and earnings management. The Accounting Review, v. 80, n. 2, p. 441-476, 2005.

COASE, R.H. Industrial organization: a proposal for research. In: COASE, R. H. Policy issues and research opportunities in industrial organization. New York: National Bureau of Ecomic Research, 1972.

COASE, R.H. The nature of the firm. Econômica, v. 4, p. 386-405, 1937. 
COASE, R.H. The nature of the firm. In: STIGLER, G.; BOULDING, K. (eds.) Readings in price theory. Homewood, IL: Richard D. Irwin, 1952.

COHEN, D.A.; ZAROWIN, P. Accrual-based and real earnings management activities around seasoned equity offerings. Working Paper. New York University Stern School of Business, Jan. 2008.

COLES, J.L.; HERTZEL, M.; KALPATHY, S. Earnings management around employee stock option reissues. Journal of Accounting and Economics, v. 41, p. 173-200, 2006.

COMISSÃO DE VALORES MOBILIÁRIOS (CVM). Companhias abertas participantes do mercado. 2011. Disponível em: <http://www.cvm.gov.br/> Acesso em: 05 a 09 nov. 2011.

COMISSÃO DE VALORES MOBILIÁRIOS (CVM). Instrução CVM n. 480, de 7 de dezembro de 2009. Dispõe sobre o registro de emissores de valores mobiliários admitidos à negociação em mercados regulamentados de valores mobiliários. Disponível em: <http://www.bmfbovespa.com.br/empresas/download/InstrucaoCVM48 0.pdf> Acesso em 14 set. 2011.

COMPRIX, J.; MULLER, K.A. III. Asymmetric treatment of reported pension expense and income amounts in CEO cash compensation calculations. Journal of Accounting and Economics, v. 42, p. 385-416, 2006.

COMPUSTAT. ExecuComp. 2011. Disponível em: $<$ http://www.compustat.com/products.aspx?id=2147492873> Acesso em: 19 set. 2011.

COORDENAÇÃO DE APERFEIÇOAMENTO DE PESSOAL DE NÍVEL SUPERIOR (CAPES). WEBQUALIS. 2012. Disponível em: $<$ http://qualis.capes.gov.br/webqualis/ConsultaListaCompletaPeriodicos .faces $>$ Acesso em 12 jul. 2012.

COORDENAÇÃO DE APERFEIÇOAMENTO DE PESSOAL DE NÍVEL SUPERIOR (CAPES). Periódicos cadastrados. 2011. Disponível em: 
〈http://www.periodicos.capes.gov.br/portugues/index.jsp> Acesso em 04 mar. 2011.

CUPERTINO, C.M. Earnings management: estudo de caso do Banco Nacional. Revista de Contabilidade \& Finanças - USP, São Paulo, n. 41, p. 110-120, mai./ago. 2006.

DALMACIO, F.Z.; REZENDE, A.J.; SLOMSKI, V. Análise setorial das medidas de performance utilizadas nos contratos de remuneração dos gestores. Revista Universo Contábil, v. 5, n.3, p. 06-23, jul./set. 2009.

DEANGELO, H.; DEANGELO, L.; SKINNER, D.J., Accounting choice in troubled companies. Journal of Accounting and Economics, v. 17, p. 113-143, 1994.

DEANGELO, L.E. Accounting numbers as market valuation substitutes: a study of management buyouts of public stockholders. The Accounting Review, v. 61, p. 400-420, 1986.

DECHOW P.M., RICHARDSON, S.A.; TUNA, I. Why are earnings kinky? An Examination of the Earnings Management Explanation Review of Accounting Studies, v. 8, p. 355-384, 2003.

DECHOW, P.; SLOAN, R.; SWEENEY, A. Causes and Consequences of Earnings Manipulation: An Analysis of Firms Subject to Enforcement Actions by SEC. Contemporary Accounting Research, v. 13, n. 1, p. 136, 1996.

DECHOW, P.M.; HUSON, M.R.; SLOAN, R.G. The effect of restructuring charges on executives' cash compensation. The Accounting Review, v. 69, n. 1, p. 138-156, Jan. 1994.

DECHOW, P.M.; SKINNER, D.J. Earnings management: reconciling the views of accounting academics, practitioners, and regulators. Accounting Horizons, v. 14, n. 2, p. 235-250, 2000.

DECHOW, P.M.; HUTTON, A.P.; KIM, J.H.; SLOAN, R.G. Detecting earnings management: a new approach. In: The Journal of Accounting Research Annual Conference, Chicago, 2011. Anais... Chicago Booth: Chicago, 2011. Disponível em: 
$<$ http://www.chicagobooth.edu/jar/conference/docs/sloan-et-alpaper.pdf > Acesso em 22 fev. 2012.

DECHOW, P.M.; SLOAN, R.G. Executive incentives and the horizon problem: an empirical investigation. Journal of Accounting and Economics. Rochester, v. 14, p.51-89, 1991.

DECHOW, P.M.; SLOAN, R.G.; SWEENEY, A.P. Detecting earnings management. The Accounting Review, v.70, p.193-225, 1995.

DEFOND, M.L.; JIAMBALVO, J. Debt covenant violation and manipulation of accruals. Journal of Accounting and Economics, v. 17, p. 145-176, 1994.

DEGEORGE, F.; PATEL, J.; ZECKHAUSER, R. Earnings management to exceed thresholds. Journal of Business, v. 72, n. 1, 1999.

DEMSETZ, H. Ownership, control, and the firm. Oxford: Basil Blackwell, 1990.

ECONOMÁTICA. Base de dados econômico-financeiros. 2012. Dados disponíveis nas demonstrações econômico-financeiras das companhias abertas registradas na Comissão de Valores Mobiliários (CVM). 2012.

EDERHOF, M. Incentive compensation and promotion-based incentives of mid-level managers: evidence from a multinational corporation. The Accounting Review, v. 86, n. 1, p. 131-153, 2011.

EISENHARDT, K.M. Agency theory: an assessment and review. The Academy of Management Review, v.14, n. 1, p. 57-74, Jan. 1989.

EISENHARDT, K.M. Control: organizational and economic approaches. Management Science, v. 31, p. 134-149, 1985.

ENGEL, E.; HAYES, R.M.; WANG, X. CEO turnover and properties of accounting information. Journal of Accounting and Economics, v. 36, p. 197-226, 2003. 
FAMA, E.F. Agency problems and the theory of the firm. Journal of Political Economy, v. 88, p. 288-307, 1980.

FAMA, E.F.; FRENCH, K.R. Industry costs of equity, Journal of Financial Economics, v. 43, p. 153-193, 1997.

FAMA, E.F.; JENSEN, M.C. Separation of ownership and control. Journal Law and Economics, v. 26, ed. sup., p. 301-25, jun. 1983.

FARRELL, K.A.; WHIDBEE, D.A. Impact of firm performance expectations on CEO turnover and replacement decisions. Journal of Accounting and Economics, v. 36, p. 165-196, 2003.

FARRELL, K.A.; WHIDBEE, D.A. The consequences of forced CEO succession for outside directors. CBA Faculty Publications. Paper 5, 2000.

FÁVERO, L.P.; BELFIORE, P.; SILVA, F.L.; CHAN, B.L. Análise de dados: modelagem multivariada para tomada de decisões. Rio de Janeiro: Elsevier, 2009.

FERRARINI, G.; MOLONEY, N. Executive remuneration in the EU: the context for reform. Oxford Review of Economic Policy, v. 21, n. 2, p. 304-323, 2010.

FORBES. CEO compensation: home page for the world's business leaders. 2009.

Disponível em:

http://www.forbes.com/2009/04/22/executive-pay-ceo-leadershipcompensation-best-boss-09-ceo_land.html> Acesso em: 19 set. 2011.

FRANKEL, R. Managing Reported Operating Cash Flow: An Empirical Investigation of Fourth Quarter Working Capital Decreases and Benchmark Beating. Working Paper, Sloan School of Management Massachusetts Institute of Technology, Jan. 2005.

GALDI, F.C. CARVALHO, L.N. Remuneração em opções de ações: o SFAS 123 revisado. Revista de Contabilidade e Finanças - USP, São Paulo, ed. com., p. 23-35, set. 2006.

GAVER, J.G.; GAVER, K.M. Additional evidence on the association between the investment opportunity set and corporate financing, 
dividend and compensation policies. Journal of Accounting and Economics, v. 16, p. 125-160, 1993.

GAVER, J.G.; GAVER, K.M. The relation between nonrecurring accounting transactions and ceo cash compensation. The Accounting Review, v. 73, n. 2, p. 235-253, Apr. 1998.

GAVER, J.J.; GAVER, K.M.; AUSTIN, J.R. Additional evidence on bonus plans and income management. Journal of Accounting and Economics, v. 19, p. 3-28, 1995.

GIL, A.C. Como elaborar projetos de pesquisa. São Paulo: Atlas, 2002.

GREENBURRY REPORT. Director's remuneration. 17 Jul. 1995. Disponível em: <http://www.ecgi.org/codes/documents/greenbury_less_recommendatio ns.pdf> Acesso em: 16 set. 2011.

GUIDRY, F.; LEONE, A.J.; ROCK, S. Earnings-based bonus plans and earnings management by business-unit managers. Journal of Accounting and Economics, v. 26, p. 113-142, 1999.

GUNNY, K. What are the consequences of real earnings management? Working Paper. Haas School of Business University of California, Jan. 2005.

GUPTA, M; PEVZNER, M.; SEETHAMRAJU, C. The implications of absorption cost accounting and production decisions for firms' future performance and valuation. Seminar at New York University, at University of Arkansas and at Washington University, Nov. 2005.

HAIR JÚNIOR, J.F.; BLACK, W.C.; BABIN, B.J.; ANDERSON, R.E.; TATHAM, R.L. Análise multivariada de dados. 6 ed. Porto Alegre: Bookman, 2009.

HANLON, M.; RAJGOPAL, S.; SHEVLIN, T. Are executive stock options associated with future earnings? Journal of Accounting and Economics, v. 36, p. 3-43, 2003. 
HARRIS, M.; RAVIV, A. Optimal incentive contracts with imperfect information. Journal of Economic Theory, vol. 20, p. 231-259, 1979.

HAYNES, M; THOMPSON, S.; WRIGHT, M. Executive remuneration and corporate divestment: motivating managers to make unpalatable decisions. Journal of Business Finance \& Accounting, v. 34, n. 5-6, p. 792-818, Jun./Jul. 2007.

HEALY, P.M. Discussion of earnings-based bonus plans and earnings management by business unit managers. Journal of Accounting and Economics, v. 26, p. 143-147, 1999.

HEALY, P.M. The effect of bonus schemes on accounting decisions. Journal of Accounting and Economics, v. 7, p. 85-107, 1985.

HEALY, P.M. The impact of bonus schemes on accounting decisions. 1983. Dissertation. University of Rochester, Rochester.

HEALY, P.M.; WAHLEN, J.M. A review of the earnings management literature and its implications for standard setting. Accounting Horizons, v. 13, n. 4, p. 365-383, 1999.

HOLSMSTRÖM, B. Moral hazard and observability. The Bell Journal of Economics, vol. 10, n. 1, p. 74-91, spring, 1979.

HOLTHAUSEN, R.W.; LARCKER, D.F.; SLOAN, R.G. Annual bones schemes and the manipulation of earnings. Journal of Accounting and Economics, v. 19, p. 29-74, 1995.

HUNTON, J.E.; MAULDIN, E.G.; WHEELER, P.R. Potential functional and dysfunctional effects of continuous monitoring. The Accounting Review, v. 83, n. 6, p. 1551-1569, 2008.

INSTITUTO BRASILEIRO DE GEOGRAFIA E ESTATÍSTICA (IBGE). Pesquisa industrial mensal, produção física, dezembro de 2010. Disponível em: $<\mathrm{ftp}$ //ftp.ibge.gov.br/Industrias_Extrativas_e_de_Transformacao/Pesqui sa_Industrial_Mensal_Producao_Fisica/Fasciculos/Fasciculo_Indicador es_IBGE_Brasil/2010/> Acesso em: 24 fev. 2012. 
IQBAL, A.; STRONG, N. The effect of corporate governance on earnings management around UK rights issues. International Journal of Managerial Finance, v. 6, n. 3, p. 168-189, 2010.

JAGGI, B.; BAYDOUN, N. Evaluation of extraordinary and exceptional items disclosed by Hong Kong companies. Abacus, v. 37, n. 2, 2001.

JENSEN, M.C. The modern industrial revolution, exit, and the failure of internal control mechanisms. Journal of Finance, v. 48, p. 831-880, Jul. 1993.

JENSEN, M.C.; MECKLING, W.H. Theory of the firm: managerial behaviour, agency costs and ownership structure, Journal of Financial Economics, v. 3, n. 4, p. 305-360, 1976.

JENSEN, M.C.; MURPHY, K.J. Performance pay and top-management incentives. The Journal of Political Economy, v. 98, n. 2, p. 225-264, Apr. 1990.

JENSEN, M.C.; MURPHY, K.J. Remuneration: where we've been, how we got to here, what are the problems, and how to fix them. Finance Working Paper, n. 44, Jul. 2004.

JOBOME, G.O. Management pay, governance and performance: the case of large UK nonprofits. Financial Accountability \& Management, vol. 22, n. 4, Nov. 2006.

JOHANSSON, U.; WODILLA, J. Towards a better paradigmatic partnership between design and management. In: International DMI Education Conference, France, 2008. Anais... ESSEC Business School: Cery-Pointoise, France, 2008.

JONES, J.J. Earnings management during import relief investigations. Journal of Accounting Research, v. 29, n. 2, p. 193-228, Out. 1991.

KALYTA, P. Accounting Discretion, Horizon Problem, and CEO Retirement Benefits. The Accounting Review, v. 84, n. 5, p. 1553-1573, 2009. 
KANG, S-H.; SIVARAMAKRISHNAN, K. Issues in testing earnings management and an instrumental variable approach. Journal of Accounting and Economics, v. 33, n. 2, p. 353-368, 1995.

KEY, K.G. Political cost incentives for earnings management in the cable television industry. Journal of Accounting and Economics, v. 23, p. 309-337, 1997.

KLANN, R. C. Gerenciamento de Resultados: análise comparativa de empresas brasileiras e inglesas antes e após a adoção das IFRS. 2011. 297f. Tese (Doutorado em Ciências Contábeis e Administração) Programa de Pós-Graduação em Ciências Contábeis da Universidade Regional de Blumenau, Blumenau, 2011.

KNIGHT, F. Risk, uncertainty and profit. New York: Harper \& Row, 1965.

LAMBERT, R.A. Contracting theory and accounting. Journal of Accounting and Economics, v. 32, p. 3-87, 2001.

LAMBERT, R.A.; LARCKER, D.F. An analysis of the use of accounting and market measures of performance in executive compensation contracts. Journal of Accounting Research, v. 25, sup. 1987.

LAND, J.; LANG, M.H. Empirical Evidence on the Evolution of International Earnings. The Accounting Review, v. 77, sup., p. 115133, 2002.

LANG, M.; RAEDY, J.S.; WILSON, W. Earnings Management and Cross Listing: are reconciled earnings comparable to US earnings? Journal of Accounting and Economics, vol. 42, n. 1-2, p. 255-283, 2006.

LARCKER, D.F. Discussion of employee stock options, EPS dilution, and stock repurchases. Journal of Accounting and Economics, v. 36, p. 45-49, 2003.

LATTIN, J.M.; CARROL, J.D.; GREEN, P.E. Análise de dados multivariados. São Paulo: Cenguage Learning, 2011. 
LAUX, C.; LAUX, V. Board committees, CEO compensation, and earnings management. The Accounting Review, v. 84, n. 3, p. 869-891, 2009.

LIBBY, R.; KINNEY JR., William, R. Does mandated audit communication reduce opportunistic corrections manage earnings to forecasts? The Accounting Review, v.75, n. 4, p. 383-404, 2000.

LLEWELLYN, K. What price contract? An essay in prospective. Yale Law Journal, v. 40, p. 704-751, Mai. 1931.

MACHADO, D.G.; BENETTI, J.E.; BEZERRA, F.A. Análise da produção científica sobre earnings management em periódicos nacionais e internacionais de contabilidade. Revista Portuguesa e Brasileira de Gestão, v. 4, p. 50-66, 2011.

MARCONI, M.A.; LAKATOS, E.M. Técnicas de pesquisa: planejamento e execução de pesquisas, amostragens e técnicas de pesquisas, elaboração, análise e interpretação de dados. 5 ed. São Paulo: Atlas, 2002.

MARTINEZ, A.L. Gerenciamento dos resultados contábeis: estudo empírico das companhias brasileiras. 2001. 167 f. Tese (Doutorado em Controladoria e Contabilidade). FEA/USP. Faculdade de Economia e Administração e Contabilidade, Universidade de São Paulo, São Paulo.

MARTINEZ, A.L. Listagem em segmentos especiais de governança corporativa e a auditoria minimizam o gerenciamento de resultados por escolhas contábeis e por decisões operacionais? Evidências do Brasil, Revista Universo Contábil, Blumenau, v. 7, n. 4, p. 98-117, out./dez., 2011.

MASTEN, S.E. A legal basis for the firm. In: WILLIAMSON, O.E.; WINTER, S.G. (eds.) The nature of the firm: origins, evolution and development. New York: Oxford University Press, 1993.

MATOS, F.F.J.; SANCOVSCHI, M. Earnings management: the case of Lucent Technologies. Revista Universo Contábil, Blumenau, v. 1, n. 1, p $101-111$, jan./abr. 2005. 
MATSUMOTO, D. A. Management's incentives to avoid negative earnings surprises. The Accounting Review, v. 77, n. 3, p.483-514, 2002.

MCANALLY, M.L.; SRIVASTAVA, A.; WEAVER, C.D. Executive stock options, missed earnings targets, and earnings management. The Accounting Review, v. 83, n. 1, p. 185-216, 2008.

MCKNIGHT, P.J.; TOMKINS, C.; WEIR, C.; HOBSON, D. CEO age and top executive pay: a UK empirical study. Journal of Management and Governance, v. 4, p. 173-187, 2000.

MCNICHOLS, M. Evidence of informational asymmetries from management earnings forecasts and stock returns. The Accounting Review, v. 64, n. 1, p.1-27, 1989.

MCNICHOLS, M.; WILSON, G.P. Evidence of earnings management from the provision for bad debts. Journal of Accounting Research, v. 26, sup., p. 1-31, 1988.

MCVAY, S. E. Earnings management using classification shifting: an examination of core earnings and special items. The Accounting Review, v. 81, n. 3, p. 501-531, 2006.

MEEK, G.K.; RAO, R. P.; SKOUSEN, C.J. Evidence on factors affecting the relationship between CEO stock option compensation and earnings management. Review of Accounting and Finance, v. 6, n. 3, p. 304-323, 2007.

MILGROM, M. Adverse selection without hidden information. Working paper. University of California, 1987.

MINGOTI, S.A. Análise de dados através de métodos de estatística multivariada: uma abordagem aplicada. Belo Horizonte: UFMG, 2005.

MORGAN, G. Paradigms, metaphors, and puzzle solving in organization theory. Administrative Science Quartely, v. 25, n. 4, p. 605-622, 1980.

MOURA NETO, A.J.S. et al. Cápsulas de Ciência. Rio de Janeiro: Quartet, 2008. 
MURPHY, K.J. Executive compensation. Forthcoming in: ASHENFELTER, O.; CARD, D. (Eds.). Executive pay: handbook of labor economics, v. 3, North Holland: CEO publication, 1999.

MURPHY, K.J. Performance standards in incentive contracts. Journal of Accounting and Economics, v. 30, p. 245-278, 2001.

MURPHY, K.J., SANDINO, T. Executive pay and independent compensation consultants. Journal of Accounting and Economics, v. 49, p. 247-262, 2010.

NAGAR, V.; NANDA, D.; WYSICKI, P. Discretionary disclosure and stock-based incentives. Journal of Accounting and Economics, v. 34, p. 283-309, 2003.

NASCIMENTO, C.; FRANCO, L.M.G.; CHEROBIM, A.P.M.S. Associação entre remuneração variável e indicadores financeiros: evidências do setor elétrico. Revista Universo Contábil, vol. 8, n. 1, p. 22-36, jan./mar., 2012.

NORTH, D. Institutions, institutional change and economic performance. Cambridge: Cambridge University Press, 1991.

NUNES, A.A.; MARQUES, J.A.V.C. Planos de incentivos baseados em opções de ações: uma exposição das distinções encontradas entre as demonstrações contábeis enviadas à CVM e à SEC. Revista de Contabilidade e Finanças - USP, São Paulo, n. 38, p. 57-73, mai./ago. 2005.

OLIVA, E.C.; ALBUQUERQUE, L.G. Sistema de remuneração de executivos e conselheiros como suporte à estrutura de governança corporativa. BASE - Revista de Administração e Contabilidade da Unisinos, v. 4, n. 1, p. 61-73, jan./abr. 2007.

OLIVEIRA, S.L. Tratado de metodologia científica: projetos de pesquisas, TGI, TCC, monografias, dissertações e teses. São Paulo: Pioneira Thomson Learning, 2002.

OYADOMARI, J.C.T.; CESAR, A.M.R.V.C.; SOUZA, E.F. OLIVEIRA, M.A. Influências da Remuneração de Executivos na 
Congruência de Metas. Revista Contemporânea de Contabilidade, Florianópolis, v.1, n.12, p. 53-74, jan./jun. 2009.

OZKAN, N. CEO. Pay-for-Performance Sensitivity and Corporate Governance: An Empirical Investigation of UK Panel Data. Working Paper. University of Bristol, England, School of Economics, Finance and Management, Apr., 2007.

PAE, J. Expected accrual models: the impact of operating cash flows and reversal of accruals. Review of Quantitative Finance and Accounting, v. 24, p. 5-22, 2005.

PAULO, E. Manipulação das informações contábeis: uma análise teórica e empírica sobre os modelos operacionais de detecção de gerenciamento de resultados. 2007. 269 f. Tese (Doutorado em Ciências Contábeis) - Faculdade de Economia, Administração e Contabilidade da Universidade de São Paulo, São Paulo.

PEASNELL, K.V.; POPE P.F.; YOUNG, S. Accrual management to meet earnings targets: UK evidence pre- and post-Cadbury. British Accounting Review, vol. 32, p. 415-445, 2000.

PENI, E.; VÄHÄMAA, S. Female executives and earnings management. Managerial Finance, v. 36, n. 7, p. 629-645, 2010.

POWNALL, G. Discussion of the relative informativeness of accounting disclosures in different countries. Journal of Accounting Research, v. 31, p. 224-229, 1993.

PRATT, J.W.; ZECKHAUSER, R.J. Principals and agents: an overview. In: PRATT, J.W.; ZECKHAUSER, R.J. (eds.). Principals and agents: the structure of american business. Boston Harvard Business Scholl Press, 1985.

RICHARDSON, R.J. Pesquisa social: métodos e técnicas. São Paulo: Atlas, 1989.

RODRIGUES, J.J.M.; SEABRA, F.M.S.H. Remuneração dos administradores dos bancos portugueses do PSI20. Revista Universo Contábil, v. 7, n. 2, p. 130-145, abr./jun., 2011. 
ROSS, S.A. The economic theory of agency: the principal's problem. The American Economic Review, vol. 63, n. 2, p. 134-139, 1973.

ROYCHOWDHURY, S. Earnings management through real activities manipulation. Working paper. Sloan School of Management University of Rochester, 2005.

SANTOS, V.; RENGEL, S. HEIN, N. Correlações canônicas entre os indicadores tradicionais e o modelo Fleuriet na avaliação do capital de giro de empresas têxteis. In: Congresso Brasileiro de Custos, XVI, 2009, Fortaleza. Anais... Fortaleza: ABCustos, 2009. CD-ROM.

SCHIPPER, Katherine. Earnings management. Accounting Horizons, v. 3, n. 4, p. 91-102, 1989.

SECURITIES AND EXCHANGE COMMISSION (SEC). Rule: executive compensation - Release n. 34-1823 of 11 aug. 1938. Disponível em: < http://search.sec.gov/secgov/index.jsp\#queryResultsTop> Acesso em: 17 set. 2011.

SECURITIES AND EXCHANGE COMMISSION (SEC). Rule: executive compensation - Release n. 33-6486 of 23 sep. 1983. Disponível em: < http://search.sec.gov/secgov/index.jsp\#queryResultsTop> Acesso em: 17 set. 2011.

SECURITIES AND EXCHANGE COMMISSION (SEC). Search for company feelings. 2011. Disponível em: <http://www.sec.gov/> Acesso em: 10 a 25 nov. 2011.

SHAVELL, S. Risk sharing and incentives in the principal and agent relationship. The Bell Journal of Economics, vol. 10, n. 1, Spring, 1979.

SHLEIFER, A.; VISHNY, R. A Survey of corporate governance. Journal of Finance, v. 52, n. 2, p. 737-783, 1997.

SILVA, J.O. Relação entre a remuneração variável dos gestores e o gerenciamento de resultados nas empresas de capital aberto brasileiras. 2010. 105 f. Dissertação (Mestrado em Ciências Contábeis) - Programa de Pós-Graduação em Ciências Contábeis da Universidade Regional de Blumenau, Blumenau, 2010. 
SIMON, H. A. Administrative behavior. New York: Free Press, 1947.

SLOAN, R. G. Accounting earnings and top executive compensation. Journal of Accounting and Economics, v. 16, p. 55-100, 1993.

SMITH Jr., C.W.; WATTS, R.L. The investment opportunity set and corporate financing, dividend, and compensation policies. Journal of Financtal Economics, v. 32, p. 263-292, 1992.

SMITH, A. A riqueza das nações: investigação sobre sua natureza e suas causas. São Paulo: Abril Cultural, 1983. 2v. (Os Economistas).

SOUZA, F.C.; BORBA, J.A. Governança corporativa e remuneração de executivos: uma revisão de artigos publicados no exterior. Contabilidade Vista \& Revista, v. 18, n. 2, p. 35-48, abr./jun. 2007.

SPENCE, M.; ZECKHAUSER, R. Insurance, Information, and Individual Action. The American Economic Review, vol. 61, n. 2, p. 380-387, 1971.

SROUR, R.H. Poder, cultura e ética nas organizações. Rio de Janeiro: Campus, 1998.

SUBRAMANIAM, N. Agency theory and accounting research: an overview of some conceptual and empirical issues. In: HOQUE, Z. Methodological issues in accounting research: theories, methods and issues. London: Spiramus Press Ltd., 2006.

SUZIGAN, W.; FURTADO, J. GARCIA, R.; SAMPAIO, S.E.K. Coeficientes de Gini locacionais - GL: aplicação à indústria de calçados do Estado de São Paulo. Nova Economia, vol. 13, n. 2, p. 39-60, jul. / dez., 2003.

TEOH, S.H.; WELCH, I.; WONG, T.J. Earnings management and the long-run market performance of initial public offerings. The Journal of Finance, v. 53, n. 3, p. 1935-1974, 1998.

THE WALL STREET JOURNAL. Survey of CEO Compensation. $2009 . \quad$ Disponível em: http://graphicsweb.wsj.com/php/CEOPAY09.html> Acesso em 19 set. 2011. 
THOMSON ONE BANKER. Base de dados econômico-financeiros. 2011. Disponível em: <http://.thomsonib.com> Acesso em: 21 nov. 2011.

U.S. CENSUS BUREAU. Economic statistics - manufacturing. 2010. Disponível em: <http://www.census.gov/econ/index.html> Acesso em: 24 fev. 2012.

UK NATIONAL STATISTICS - OFFICE FOR NATIONAL STATISTICS. UK productivity by setor. 2012. Disponível em: <http://www.statistics.gov.uk/hub/labour-market/people-inwork/productivity/index.html> Acesso em 24 fev. 2012.

WALLACE, J.S. Adopting residual income-based compensation plans: do you get what you pay for? Journal of Accounting and Economics, v. 24, p. 275-300, 1997.

WHITE, C.W. Agency as control. In: PRATT, J.W.; ZECKHAUSER, R.J. (eds.). Principals and agents: the structure of american business. Boston Harvard Business Scholl Press, 1985.

WILLIAMSON, O.E. Las instituciones económicas del capitalismo. Ciudad de México: Fondo de Cultura Económica, 1989.

WILLIAMSON, O.E. Markets and hierarchies: analysis and antitrust implications. New York: Free Press, 1975.

WILLIAMSON, O.E. The economic institutions of capitalism: firms, markets, relational contracting. New York: Free Press, 1985.

WILSON, R. On the theory of syndicates. Econometrica, v. 36, n. 1, p. 119-132, 1968.

WINSHIP, C.; ROSEN, S. Introduction: sociological and economic approaches to the analysis of social structure. American Journal of Sociology, v. 94, p. 1-16, 1988.

YAPING, N. The theoretical framework of earnings management. Canadian Social Science, v. 1, n. 3, p. 32-38, Nov. 2005. 
ZANG, A.Y. Evidences on the tradeoff between real manipulation and accrual manipulation. Working paper. Fuqua School of Business, 2005.

ZEITLIN, M. Corporate ownership and control: the large corporation and the capitalist class. American Journal of Sociology, v. 73, p. 10731119, 1974.

ZYLBERSTAJN, D. Estrutura de governança e coordenação do agribusiness: uma aplicação da nova economia das instituições. 1995. 238 f.. Tese (livre docência). Departamento de Administração da Faculdade de Economia, Administração e Contabilidade da universidade de São Paulo. São Paulo.

ZYLBERSZTAJN, D. Papel dos contratos na coordenação agroindustrial: um olhar além dos mercados. RER, Rio de Janeiro, v. 43, n. 3, p. 385-420, jul./set. 2005. 